


\section{Lessons from ADB Transport Projects:}

Moving Goods, Connecting People, and Disseminating Knowledge 

(C) 2017 Asian Development Bank

6 ADB Avenue, Mandaluyong City, 1550 Metro Manila, Philippines

Tel +632632 4444; Fax +6326362444

www.adb.org

Some rights reserved. Published in 2017.

ISBN 978-92-9257-859-6 (Print), 978-92-9257-860-2 (e-ISBN)

Publication Stock No. TIM178778-2

DOI: http://dx.doi.org/10.22617/TIM178778-2

The views expressed in this publication are those of the authors and do not necessarily reflect the views and policies of the Asian Development Bank (ADB) or its Board of Governors or the governments they represent.

ADB does not guarantee the accuracy of the data included in this publication and accepts no responsibility for any consequence of their use. The mention of specific companies or products of manufacturers does not imply that they are endorsed or recommended by ADB in preference to others of a similar nature that are not mentioned.

By making any designation of or reference to a particular territory or geographic area, or by using the term "country" in this document, ADB does not intend to make any judgments as to the legal or other status of any territory or area.

This work is available under the Creative Commons Attribution 3.0 IGO license (CC BY 3.0 IGO)

https://creativecommons.org/licenses/by/3.0/igo/. By using the content of this publication, you agree to be bound by the terms of this license. For attribution, translations, adaptations, and permissions, please read the provisions and terms of use at https://www.adb.org/terms-use\#openaccess

This CC license does not apply to non-ADB copyright materials in this publication. If the material is attributed to another source, please contact the copyright owner or publisher of that source for permission to reproduce it. ADB cannot be held liable for any claims that arise as a result of your use of the material.

Please contact pubsmarketing@adb.org if you have questions or comments with respect to content, or if you wish to obtain copyright permission for your intended use that does not fall within these terms, or for permission to use the ADB logo.

Notes:

In this publication, "\$" refers to US dollars

Corrigenda to ADB publications may be found at http://www.adb.org/publications/corrigenda 


\section{CONTENTS}

FOREWORD

ACKNOWLEDGMENT

- The River More Traveled: Navigable Inland Waterway in the People's Republic of China

From Shore to Sea: Land and Resettlement Issues in Port Development in

Papua New Guinea

- Mega Port for Mega Ships: Attracting Partners for Port Expansion in Sri Lanka

\section{UP IN THE AIR}

Fly Safe, Fly Happy: The Role of Policy and Institutions in Improving Aviation in Bhutan

- Change Is In The Air: Multitranche Financing for Improving Aviation in Papua New Guinea

\section{ON TRACK}

- Trade and Aid Express: Rail Construction in a High Security Risk Environment in Afghanistan

- A Train for Two Cities: Railway on Rugged Terrain in the People's Republic of China

\section{URBAN TRANSPORT SOLUTIONS}

- Public Transport for a New City Center: Urban Options in the People's Republic of China

- Rapid Bus Services for a Busy City: Optimized Urban Roads in the People's Republic of China 


\section{CROSS-COUNTRY CORRIDORS}

Cross-Country Connections: Computerized Transport and Trade Logistics in Nepal

Connecting Key Cities: Cross-Border Road Rehabilitation in Kazakhstan and the Kyrgyz Republic

IN-COUNTRY EXPRESSWAYS

- Highway Through the Highlands: Innovative Road in the People's Republic of China 87

- Shifting Gears to Growth: Greenfield Highway Construction in Sri Lanka

\section{RURAL ROAD CONNECTIONS}

- Paving the Way to Change: Creating a Safe Road Environment in Rural Cambodia 104

Roads Out of Poverty: Supporting the National Program for Rural Road Development in India

\section{ROAD MAINTENANCE}

Care, Caution, and Connectivity: Participatory Processes in Road Improvements in Bangladesh

120

Making Roads Last Longer: Better Road Care in the People's Republic of China 
The Asian Development Bank (ADB), the largest multilateral development finance institution in Asia and the Pacific, has been providing project financing to its developing member countries (DMCs) for half a century. In the process, it has accumulated a wealth of knowledge from its operations, including innovations, good practices, lessons, and ways to tackle challenges during project design and implementation. The capture, sharing, and eventually reuse of the knowledge, play an increasingly important role in achieving greater development effectiveness.

Efficient transport system is a key factor in promoting inclusive economic development, reducing poverty, and improving the quality of life. It will improve trade and connect farms to markets. People will gain access to jobs, schools, and healthcare.. For $\mathrm{ADB}$, the transport sector has been one of the most important sectors since its establishment in 1966. As of 31 December 2016, ADB's ordinary capital resources loans in the transport sector amounted to $\$ 36$ billion, accounting for $35 \%$ of ADB's total OCR loans. In Strategy 2020, ADB's Long-Term Strategic Framework, 2008-2020, expanding transport and communication connectivity in the region and other infrastructure investments were recognized as one of the five core areas of ADB's operational focus.

This book, Lessons from ADB Transport Projects: Moving Goods, Connecting People, and Disseminating Knowledge, endeavors to harvest practical knowledge from ADB's operations in the transport sector. ADB's Economic Research and Regional Cooperation Department gathered the knowledge for this book in collaboration with the Transport Sector Group and regional departments, including resident missions. This work was produced under the regional technical assistance (Provision of Knowledge Products and Services to Developing Member Countries through Systematic Knowledge Sharing [TA 8392-REG]), which aims to support-in a systematic manner-the capture and sharing of the knowledge embedded in ADB's development projects, among other things.

Comprising a sector overview and 20 case stories that covers different subregions and subsectors, this book captures and shares ADB-wide operations knowledge in the transport sector to promote cross-project learning. We hope the readers, particularly government officials, executing and implementing agencies in the DMCs, and ADB project officers, will find this book informative and useful, and allow it to influence and improve the design and implementation of future transport projects for enhanced development effectiveness.

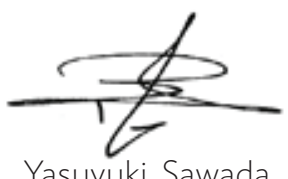

Yasuyuki Sawada

Chief Economist and Director General

Economic Research and Regional Cooperation Department Asian Development Bank 
The publication entitled Lessons from ADB Transport Projects: Moving Goods, Connecting People, and Disseminating Knowledge was produced under the Asian Development Bank (ADB) regional technical assistance on Provision of Knowledge Products and Services to Developing Member Countries through Systematic Knowledge Sharing, supported by the ADB-administered People's Republic of China Poverty Reduction and Regional Cooperation Fund.

Dongxiang Li led the task team and steered the production of the publication, assisted by Aleli Rosario. Christina Duenas was a member of the team at its early stage. Lourdes Didith Mendoza Rivera and Cezar Tigno undertook the research and initial write-up of the sector overview and the project cases.

The projects showcased here were chosen in collaboration with the Transport Sector Group headed by Tyrrell Duncan, who also provided overall guidance and technical insights on contents. Lloyd Wright provided comments while data support was given by Melissa May Cardenas and Jane Romero from the Transport Sector Group.

Extracting knowledge from the selected transport projects was only possible with the participation and support of the transport divisions in ADB's regional departments, and the respective project officers in ADB headquarters and in resident missions. They are Balabhaskara Reddy Bathula, Bhupendra Bhatt, Xiaoxin Chen, Alexandra Pamela Chiang, Chenglong Chu, Shihiru Date, David Fay, Andri Heriawan, Muhammad Amir Ingratubun, Muhammad Nazrul Islam, Tomoaki Kawabata, Ki-joon Kim, Dong Kyu Lee, Cai Li, Aruna Uddeeptha Nanayakkara, Shiva Prasad Paudel, Prianka Seneviratne, Yasushi Tanaka, M. Thiruchelvam, Hiroaki Yamaguchi, Kenichi Yokoyama.

The publication was edited by Ricardo Chan, and assistance was provided by Sharon Lynn Dela Torre. Erickson Mercado was responsible for typesetting, graphics generation, and the cover design. Abraham Villanueva generated the maps used in some project cases. Pictures were also provided by Sallyanne Shute-Trembath and Marites Ortega. Administrative and secretarial support was provided by Maria Melissa Gregorio-dela Paz. For printing and publishing, assistance was provided by the Printing Services Unit of ADB's Office of Administrative Services and by the Publishing and Dissemination Unit of ADB's Department of External Relations. 


\section{ABBREVIATIONS}

\begin{tabular}{|c|c|}
\hline$A D B$ & Asian Development Bank \\
\hline ASYCUDA & Automated System for Customs Data \\
\hline CAREC & Central Asia Regional Economic Cooperation \\
\hline DMC & developing member country \\
\hline Dwt & deadweight ton \\
\hline GDP & gross domestic product \\
\hline GHG & greenhouse gas \\
\hline GMS & Greater Mekong Subregion \\
\hline IWT & inland waterway transport \\
\hline JICA & Japan International Cooperation Agency \\
\hline MDB & multilateral development bank \\
\hline MFF & multitranche financing facility \\
\hline MW & megawatt \\
\hline NGO & nongovernment organization \\
\hline PPP & public-private partnership \\
\hline PRC & People's Republic of China \\
\hline SASEC & South Asia Subregional Economic Cooperation \\
\hline STI & Sustainable Transport Initiative \\
\hline TEU & twenty-foot equivalent unit \\
\hline WAN & wide area network \\
\hline
\end{tabular}




\section{INTRODUCTION}

The growth and development of transport sector in Asia and the Pacific have been rapid, complex, and dynamic. Policy makers and project implementers need clear and concise information to guide them in firmly grasping the changes in the sector so that they can clearly see what and how these changes apply to the sector. This is crucial, given that the region's economic growth and sustainability are largely dependent on transport. It directly contributes 5\%-10\% of gross domestic product (GDP) in most countries, and indirectly enables a wide variety of other social and economic activities.'

This overview aims to provide a brief profile of the transport sector in Asia and the Pacific, including recent historical trends, the factors affecting its growth, and the bottlenecks to its development. This information, which will mainly benefit policy makers and project implementers in the transport sector, can assist in planning, developing, and implementing projects that can adequately address transport challenges.

This overview likewise provides information on how the Asian Development Bank (ADB) has contributed to transport in the region. It shares how ADB, since its inception, has promoted the growth of transport in Asia and the Pacific. It also details the changes ADB is currently initiating to respond to the mega challenges affecting the sector and the changing needs of its developing member countries (DMCs).

\section{THE TRANSPORT SECTOR IN ASIA AND THE PACIFIC}

Transport has been an essential element in the development of Asia and the Pacific, and has played a critical role in the region's rapid economic growth. It has helped move people and goods, ensuring that labor, raw materials, products, and ideas can move around easily and contribute to the social, economic, and environmental improvement of the region. ${ }^{2}$ In 1995, there were 1.2 trillion passengerkilometers and 2.9 trillion ton-kilometers of freight transported by railways in Asia and the Pacific. This grew to 2.2 trillion passenger-kilometers (2009), and 5.5 trillion ton-kilometers of freight (2010). Moreover, as of 2012, 20 of the world's top container ports in terms of throughput are in the Asia and Pacific region. ${ }^{3}$

T. R. Lakshmanan. The Wider Economic Benefits of Transportation: An Overview. http://www.internationaltransportforum.org/jtrc/ discussionpapers/DiscussionPaper8.pdf

2 United Nations Economic and Social Commission for Asia and the Pacific (UNESCAP). 2013. Transport Review 2013. www.unescap. org/sites/default/files/transportreview_2013_full_text.pdf

3 UNESCAP. 2013. Asia Pacific Development 2012. http://www.unescap.org/stat/data/syb2012/did-you-know.asp 
Focusing on urban areas, many Asian cities have grown very rapidly in the last few decades. Large increases in population; in-city migration; as well as growing trade, economies, and incomes are among the factors that have driven demand for transport in many urban areas in the region. As per capita incomes of urban dwellers in Asia increased, vehicle ownership has likewise increased. As population in urban centers grew, so did mass transport demand. As economies rose, so has the need for inter-regional connectivity.

In response to the generally higher transport demand, transport infrastructure in Asia and the Pacific has improved over the last few decades. However, development for different modes of transportsrail, road, air, and water-across and within countries has been uneven. Some countries show a progressive pattern, while others suffer a declining trend. The most significant growth, though, happened in the roads subsector.

Road. The region's road network grew from 4.9 million kilometers in 1990 to 10.3 million kilometers by 2009. ${ }^{4}$ Not surprisingly, the People's Republic of China (PRC) and India have dominated road development. In the 1990s, they account for about 55\% of the total road network. ${ }^{5}$ By 2012, the two giant economies account for almost two-thirds of the total road network of the region. ${ }^{6}$

Historically, economies with high per capita incomes generally have high road density. Data as early as 2009 show that Hong Kong, China; Japan; and Singapore have the highest road densities in the region.? The PRC, despite having the region's second longest road network, has a low road density of 414 kilometers of road per 1,000 kilometers ${ }^{2}$ of land. Among developing countries, Bangladesh, India, and Sri Lanka have relatively high road densities. ${ }^{8}$

As national road networks grew rapidly, unpaved roads were also upgraded to hard surface. In most countries, paved roads have been growing faster than the total road network. Higher-quality roads accounted for $31.7 \%$ of the region's highway network in 2015, up from only $12.4 \%$ in $2004 .{ }^{9}$

Road network expansion was generally accompanied by higher levels of motorization. In 2007, an estimated 225.5 million motor vehicles were in use in the region. ${ }^{10}$ In the years following, the number of vehicles has surged. Many developing countries registered increasing vehicle density, with more than 100 vehicles per 1,000 people by 2015. In most of Southeast Asia, two- and three-wheeled vehicles have become the primary form of motorized transport, with their share of all registered vehicles exceeding 80\% in Cambodia, Indonesia, the Lao People’s Democratic Republic, Myanmar, and Viet Nam."1

4 ADB. 2012. Key Indicators for Asia and the Pacific 2012: Highlights. https:/www.adb.org/sites/default/files/publication/29940/ki2012highlights.pdf

5 ADB. 2008. Key Indicators for Asia and the Pacific 2008. https:/www.adb.org/sites/default/files/publication/27728/key-indicators-2008. pdf

6 ADB. 2013. Key Indicators for Asia and the Pacific 2013. https://www.adb.org/sites/default/files/publication/30358/ki2013.pdf

7 ADB. 2009. Key Indicators for Asia and the Pacific 2009. https:/www.adb.org/sites/default/files/publication/27727/key-indicators-2009. pdf

8 ADB. 2012. Key Indicators for Asia and the Pacific 2012. https://www.adb.org/sites/default/files/publication/29940/ki2012.pdf

9 ADB. 2016. Key Indicators for Asia and the Pacific 2016. https://www.adb.org/publications/key-indicators-asia-and-pacific-2016

10 Motor vehicles include passenger cars, taxis, trucks, and buses but exclude motorcycles and scooters. ADB. 2010. Key Indicators for Asia and the Pacific 2010. https:/www.adb.org/publications/key-indicators-asia-and-pacific-2010

11 ADB. 2015. Key Indicators for Asia and the Pacific 2015. https://www.adb.org/sites/default/files/publication/175162/ki2015.pdf 
Expanded road networks have improved the flow of goods, services, and people and have directly contributed to cross-border trade and promoted tourism. Asia gradually saw the need for better road connectivity to link national markets, which may help reduce the development gaps between rich and poor Asian countries by spreading the benefits of economic development. The Intergovernmental Agreement on the Asian Highway Network was adopted in 2003 to provide a framework for the coordinated, region-wide development of highways in Asia. ADB has supported the thrusts of the agreement by providing funding assistance to its member countries for developing regional roads. ${ }^{2}$

More recently, as several of the case studies in this collection show, concerns about road quality, road maintenance, and road safety as well as about the environmental impacts of road transport, have been considered in road infrastructure development. Asia's developing countries are increasing efforts to address such concerns, while also incorporating climate change resiliency in road development planning and design.

Rail. Growing trade between regions and transport-induced environmental concerns have brought to the fore the advantages of rail transport - the ability to move bulky freight for longer distances at a relatively lower cost, reduced highway congestion, and reduced carbon emissions. In Asia, many countries operate a rail network, except small Island countries or countries with very high mountainous terrain such as Bhutan. However, growth in railway infrastructure has not been as dramatic as that of the roads.

The region's rail networks are heavily concentrated in three countries - the PRC, India, and Japan. Together, they account for more than two-thirds of the region's total. From 58,656 kilometers in 2000 , the rail network of the PRC increased to 66,989 kilometers in 2014. India's railways at 62,759 kilometers in 2000 grew to 65,808 kilometers in 2014. Malaysia posted the highest average annual increase of $2.4 \%$ in rail network density between 2000 and 2014, followed by Taipei,China and Turkmenistan. ${ }^{3}$

Recently, investments in rail transport have slowly increased to improve connectivity between regions. In Central Asia, the revival of rail transport is being facilitated by the ADB-supported Central Asia Regional Economic Cooperation Program, which is pulling investments for the development of regional railways and improving cross-border trade facilitation.14 The new 75-kilometer line in Mazare-Sharif in Afghanistan, featured in this program, is proof positive of the comeback of rail transport in Central Asia. The successful opening of the railway line has led to new possibilities for railway expansion and connectivity within the region.

Container "block trains" that have started operating between the PRC and Europe are another recent development.These trains allow the movement of block freight from origin to destination, without being split up or stored en route. One example is the Yu-Xin-Ou line from Chongqing in the PRC to Duisburg in Germany via Kazakhstan, the Russian Federation, Belarus, and Poland. The train takes 16 days to travel more than 11,000 kilometers. ${ }^{15}$

12 Srinivasa Madhur, Ganeshan Wignaraja, and Peter Darjes. 2009. "Roads for Asian Integration: Measuring ADB's Contribution to the Asian Highway Network. ADB Working Paper Series on Regional Economic Integration. No. 37. https:/www.adb.org/sites/default/files/ publication/28511/wp37-roads-asian-integration.pdf

13 Footnote 9, p. 209-222.

14 ADB. 2014. CAREC Transport and Trade Facilitation Strategy 2020. https://www.adb.org/sites/default/files/institutional-document/34107/ files/carec-ttfs-2020.pdf

15 Sharad Saxena. 2016. Back on Track - Reviving Rail in Central Asia. Asian Development Blog. https://blogs.adb.org/blog/back-track- 
Air. Aviation in Asia and the Pacific generally grew over the years. For most countries, air carrier departures increased between 2000 and 2015. Topping the list, expectedly, is the PRC posting 3.6 million takeoffs in 2015, up from a mere 572,921 in 2000. India was second with 787,998 in 2015, up from 198,426 in 2000. The largest percentage increases were seen in Kazakhstan at 801.5\%, Viet Nam at $607.7 \%$, and Afghanistan at $590.3 \%$. In the same period, the number of passengers carried also increased, with the largest percentage increases occurring in Afghanistan at 1,189.1\%, Kazakhstan at 1,001.6\%, and Viet Nam at 940.5\%. In the PRC, there were about 436 million airline passengers in 2015 , up from 61 million in 2000. Air freight also increased in the same period, with the PRC also posting the highest number, at about 19,805 ton-kilometers in 2015, up from 3,900 ton-kilometers in 2000. Southeast Asian countries Malaysia, Singapore, and Thailand also registered significant and steady numbers in air freight within the 15 -year period. ${ }^{16}$

In Southeast Asia, the demand for air connectivity has been relatively high. The major hub airports of Singapore, Kuala Lumpur, and Bangkok have world-class facilities, operate efficiently by international standards, and continually invest to maintain their competitive positions. Other major airports in Brunei Darussalam, Indonesia, and the Philippines have been struggling to keep up with demand. Numerous secondary airports exist, though many need to be upgraded. ${ }^{7}$

Early in the millennium, low-cost carriers began to operate in Southeast Asia as a response to the growing demand for more airline services. Since 2003, the number of these "budget airlines" has grown rapidly, offering low-priced flight services to regional destinations, thereby capturing large market shares and directly competing with the bigger commercial airlines. As the volume of air freight has tended to expand alongside the growth of scheduled passenger services, low-cost airlines are also improving air freight services. Overall, the growth of budget airlines has been changing the regional aviation market, as the budget airlines introduce new competition to existing routes and develop new commercial routes within and outside the region. ${ }^{8}$ Likewise, low-cost airlines also began to operate in seven Pacific routes starting in 2004, successfully targeting the markets of the Fiji, Samoa, Tonga, and Vanuatu. ${ }^{19}$

An interesting in-country development is the opening of Bhutan's mountainous and rugged airspace to domestic flights. The case of Bhutan, included in this collection and which involved upgrading airport infrastructure and services, highlights the importance of aviation safety and security in enhancing air connectivity in the Asia and Pacific region.

Water. Maritime travel and trade in Asia and the Pacific is as old as its early civilizations, facilitated via the region's vast oceans and seas. Throughout the centuries, many of the old ports in East Asia, South Asia, and Southeast Asia continued to flourish, adapting to a more modern and bustling international shipping industry. In 2012, the PRC accounted for nearly half of all container port traffic in the region, posting 155,000 million twenty-foot equivalent units. Singapore was second with 32,422 twenty-foot equivalent units. Between 2000 and 2012, container port traffic generally increased

reviving-rail-central-asia

16 Footnote 9, p. 209-222.

17 Keith Trace, Barend Frielink, and Denis Hew. 2009. Air Connectivity in Archipelagic Southeast Asia: An Overview. ADB Southeast Asia Working Paper Series. https://www.adb.org/sites/default/files/publication/28671/air-connectivity.pdf

18 Footnote 17, p. 12-14.

19 ADB. 2007. Oceanic Voyages: Aviation in the Pacific. Pacific Studies Series. https://www.adb.org/publications/oceanic-voyages-aviationpacific 
across the region..$^{20}$ In 2013, Cambodia opened a new cargo terminal in its capital to meet a sharp increase in shipments moving through the country's existing ports. India, which is set to establish industrial or special economic zones in the immediate future to increase trade, has proposed a port land policy which allows land to be leased by private entities up to a maximum period of 30 years. It also has two port developments in the pipeline. In Myanmar, the government has identified two possible sites for port development. Sri Lanka's Colombo Port has recently regained its status as a transshipment hub in South Asia following an ADB-financed expansion and upgrading project that has successfully attracted private sector investments.

Less prominently, coastal and interisland shipping in the archipelagic countries of Indonesia, Malaysia, and the Philippines, and among Pacific island countries have remained in operation, providing limited connectivity among remote island communities. In Pacific island countries especially, domestic shipping is generally operated by the government or by very small, independent shipping companies. The ships are typically old and in poor condition, service schedules are sometimes not adhered to, and it is not uncommon for services to be suspended for months at a time. ${ }^{21}$

Inland waterway transport (IWT) has been receiving greater attention recently, mostly because of its potential to decrease road traffic and increase cross-border trade, while offering a more environment-friendly transport option. ${ }^{22}$ However, a variety of factors has affected the lethargic growth of inland water transport in many Asian countries. Some countries have issues related to the availability of adequate navigable waterways and the deteriorated condition of vessel fleets, with many of them needing modernization in terms of environmental performance and efficiency. Political priority is often given to the development of roads, leaving IWT largely neglected and underfunded, sometimes with outmoded institutions. Other countries find it difficult to connect water transport to other modes, such as road or rail. In the PRC, the development of inland water transport on the Xiangjiang River, featured in this publication, will make the river more navigable for larger vessels, improve cargo terminals along the river, and tap the river's hydropower potential to provide clean energy for Hunan province.

\section{CHALLENGES TO THE TRANSPORT SECTOR}

While the growth in the transport sector has improved connectivity and accessibility across Asia and the Pacific, it has also come with high costs. As the sector grew, it experienced rapid increases in motorization, which, in turn, contributed to congestion, fuel consumption, air pollution and greenhouse gas ( $\mathrm{GHG}$ ) emissions, and road collisions, among others.

Increased congestion. Urban growth and motorization in Asia and the Pacific have placed an enormous strain on transport and mobility in recent years. Asia's share of the global vehicle fleet has risen from 9\% in 1980 to $17 \%$ in $2005 .{ }^{23}$ In 2010, Asia had 460 million vehicles and the vehicle fleet will double within 7 years at the current annual average growth of $11.5 \%{ }^{24}$ A recent study by ADB and

20 Footnote 9, p. 220

21 ADB. 2007. Oceanic Voyages: Shipping in the Pacific. Pacific Studies Series. https://www.adb.org/sites/default/files/publication/29760/ shipping-pacific.pdf

22 ADB. 2013. Asia's Rivers and Canals: Inland Waterway Transport. ADB.org. https://www.adb.org/features/making-asia-flow-inlandwaterway-transport

23 ADB. 2013. Sustainable Urban Transport in Asia. Features. www.adb.org/features/sustainable-urban-transport-adbs-take

24 Clean Air Asia. 2012. Accessing Asia: Air Pollution and Greenhouse Gas Emissions from Road Transport and Electricity. http://cleanairinitiative.org/portal/sites/default/files/documents/Accessing_Asia_2012_Edition_Executive_Summary.pdf 
the International Energy Agency showed that the mode share of cars and motorcycles in the Asia and Pacific region will outnumber the combined mode share of public transport, walking, and cycling for the first time in history by the end of this decade. ${ }^{25}$ This would lead to more congestion in many Asian cities, which currently cost economies around $2 \%-5 \%$ of their GDP due to lost time and higher transport costs.

Increased fuel consumption. The increase in motorization levels in Asia leads to increased fuel consumption. Nearly two thirds of total oil consumption in the world is in the transport sector. A study by Clean Air Asia showed that fuel consumption by transport in Asia is expected to increase by more than $5 \%$ per year until 2030 because rapid urbanization and economic growth in the region result in greater demand for mobility. ${ }^{26}$ Asia will comprise $30 \%$ of the world's energy consumption by 2030 , and will demand $45 \%$ of the increase in the total world fuel use, unless actions are taken to curb fuel consumption. ${ }^{27}$

Increased air pollution. The World Health Organization estimates that about 470,000 people die prematurely in Asia each year due to exposure to air pollution. The rapidly growing transport sector is, in many Asian cities, the most significant contributor to air pollution. The economic costs of air pollution reach into the hundreds of millions of dollars per city, about $1 \%-2 \%$ of GDP at a national level. ${ }^{28}$

Climate change and GHG emissions. Without radical interventions, global carbon dioxide $\left(\mathrm{CO}^{2}\right)$ emissions from the transport sector, projected to increase to nearly $50 \%$ by 2030 , will lead to profound environmental, economic, and social consequences. Transport is currently responsible for $13 \%$ of all global GHG emissions, and $23 \%$ of global $\mathrm{CO}^{2}$ emissions from fuel combustion. In Asia, the transport sector remains one of the main sources of $\mathrm{CO}^{2}$ emissions, despite the fact that its share of total regional $\mathrm{CO}^{2}$ emissions remained constant at about $10 \%$ over the last 25 years. ${ }^{29}$ Transport infrastructure investments in the next 5-10 years to support the increase in motorization will lock in transport-related $\mathrm{CO}^{2}$ emission patterns for the coming 20-30 years in Asia. Addressing transport emissions in Asia is therefore crucial for global $\mathrm{CO}^{2}$ mitigation.

Road safety. The heightened concern for road safety in Asia arose from the growing number of road accidents, which cause over 645,000 deaths and 30 million injuries every year..$^{30}$ In 2013 , Thailand had the highest prevalence of road deaths within the region with 36 road deaths per 100,000 people. More than $70 \%$ of these road fatalities involved users of two- or three-wheeled vehicles. Viet Nam had the next highest rate of road deaths with 25 per 100,000 people, followed by the Cook Islands, Kazakhstan, and Malaysia with 24 each. By type of vehicle, four-wheeled vehicles comprised the plurality of road traffic deaths. ${ }^{31}$

25 Bindu N. Lohani. 2014. Catalyzing the Development of Low Carbon Transport in Asia and the Pacific. The Role of ADB. Keynote Address at the Symposium on Study on Long-Term Transport Action Plan for the ASEAN. 20 February. Tokyo, Japan.

26 Clean Air Asia. 2010. Improving Vehicle Fuel Economy in the ASEAN Region. Manila (working paper, July). http://cleanairinitiative.org/ portal/sites/default/files/documents/ASEAN-fueleconomy.pdf

27 Woochoong Um. 2009. Key Transport Challenges for the Transport Sector in Asia. Presentation for the Clean Air Asia Forum. 13 December.

28 ADB. 2006. Clean Cars, Clean Fuel Needed to Offset Asia's Worsening Air Pollution, Workshop Told. News Release. 22 May.

29 World Bank. 2009. Why Have CO2 Emissions Increased in the Transport Sector in Asia? Policy Research Working Paper. Washington, DC (September).

30 ADB. 2012. Road Safety Action Plan: An Overview. https://www.adb.org/sites/default/files/publication/29696/road-safety-brochure.pdf

31 Footnote 9, p. 211. 


\section{ADB AND THE TRANSPORT SECTOR}

A brief history. ADB has been supporting the transport sector since its establishment in the mid 1960 s. Four out of the first 15 ADB-approved projects in 1968 were for transport. These projects were the Air Transport System Development Project in Nepal, a fisheries port development in the Philippines, the Seoul-Inchon Expressway in the Republic of Korea, and the North-South Freeway Project in Taipei,China (see box below). ${ }^{32}$

\section{ADB's Earliest Transport Projects}

The North-South Freeway Project in Taipei,China facilitated long-distance traffic through a four-lane expressway that had four sections serving three important cities:Taipei, Tainan, and Kaohsiung. The Seoul-Incheon Expressway Project connected the Republic of Korea's capital to its main port in Incheon.

ADB's Air Transport System Project in Nepal assisted the country in formulating a sound investment program that improved its airports, airplanes, airfields, ground communication, and navigation aids, among others. ADB collaborated with the Aviation Civil Organization for this project. The fisheries port development project in the Philippines was a technical assistance grant, which assisted the country in studying possible technical alternatives in the construction and equipment of a fisheries port at the North Harbor in Manila Bay.

In addition to these projects, ADB also conducted a regional transport survey, spurred by a request from the Government of Malaysia in 1967. The survey covered seven countries: Indonesia, Lao People's Democratic Republic, Malaysia, Philippines, Singapore, Thailand, and Viet Nam. It aimed to provide a basis for a coordinated development in the Southeast Asia region.

References:

ADB. 1968. Annual Report 1968. Manila.

ADB. 1969. Annual Report 1969. Manila.

Since 1966, ADB has financed $\$ 35.6$ billion of transport investments in the region. 33 In recent years, ADB's transport investments have generally averaged around $\$ 4$ billion a year, typically accounting for around a third of ADB's total lending. A large part of these investments went to roads development. From 1970 to 2009, 74\% of the loans for this sector went to roads. From 2010 to 2014, loans for road development comprised $71 \%$ of ADB's transport lending portfolio. This trend was largely due to high demand for connectivity in member-countries, as well as rapid urbanization in many Asian cities.

Institutional context. Various divisions under different regional departments in ADB deal with transport. These include divisions which focus on urban transport services, transport and communications, transport for urban and social sectors, and transport and development. ADB's

32 ADB. 1968. Annual Report. Manila

33 ADB. 2011. Sustainable Transport for All. www.adb.org/sectors/transport/overview 
Sustainable Development and Climate Change Department (SDCC) undertakes research on the sector, including innovations on approaches and technologies. To facilitate sharing of knowledge and foster collaboration among the different divisions and promote technical cohesiveness, the Transport Community of Practice was established. 34 In 2015, this was renamed the Transport Sector Group.

The Transport Sector Group. The Transport Sector Group is comprised of representatives from all of ADB's departments-Central and West Asia, Pacific, South Asia, Southeast Asia, and East Asia, together with the Sustainable Development and Climate Change Department.35 It provides advice on strategic directions for ADB's transport sector operations and policies, strengthens the quality of transport projects through peer review, and pilots innovations in the sector. The group also fosters knowledge sharing and exchange as well as skills enhancement through trainings and knowledge events such as brown bag sessions, workshops, and transport forums, including the biennial ADB transport forum, the largest gathering of transport officials in Asia and the Pacific. Since its establishment, the group has produced various publications and awareness-raising materials, an online transport database, and a regular newsletter.

The Transport Sector Group has been crucial to ADB's response to the challenges to the transport sector. It has played and continues to play a vital role in the implementation of Strategy 2020 in the transport sector. Strategy 2020 established ADB's overarching strategic pillars of inclusive economic growth, environmentally sustainable growth, and regional integration. The Transport Sector Group advances Strategy 2020 through the Sustainable Transport Initiative (STI).

\section{STEERING TRANSPORT TO SUSTAINABILITY}

To address the emerging challenges in the transport sector, ADB launched the Sustainable Transport Initiative - Operational Plan (STI-OP) in 2010. It guides ADB investments in low-carbon, safe, accessible, and affordable transport systems and inclusive, clean, and energy-efficient transport policies and projects. The idea is to mainstream sustainability considerations into its existing areas of transport operations, and expand operations in four priority areas: urban transport, addressing climate change in transport, road safety and social sustainability, and cross-border transport and logistics.

Urban transport. In light of the rapid increases in urban population, the increasing levels of pollution and congestion in many DMCs, ADB began to scale up operations in urban transport under the STI. Initiatives in urban transport feature one or more of the following elements: innovative public transport systems, nonmotorized transport provisions, integrated urban transport planning, demand management, and traffic management systems.

Transport and climate change. As the transport sector is one of the biggest sources of GHG and $\mathrm{CO}_{2}$ emissions, the STI specified climate change as an opportunity for further support to DMCs. ADB's actions on climate change mitigation in transport are guided by the "avoid-shift-improve" approach -integrating land use development with mobility needs to avoid the need for travel, providing a shift to energy-efficient modes or routes of transport, and seeking to improve vehicle

34 ADB.2009. Annual Report of the Transport Community of Practice. Manila.

35 ADB. Transport. http://www.adb.org/site/knowledge-management/communities-of-practice/profiles/transport. (accessed 19 March 2015). 
and fuel technologies toward more energy-efficient ones. ${ }^{36}$ As for adaptation, ADB has introduced guidelines for incorporating climate change adaptation measures into transport sector investment projects, including risk evaluation, impact assessment, vulnerability assessment, and adaptation assessment. ${ }^{37}$ These guidelines help decision makers make adaptation and investment decisions for transport infrastructure in the face of climate change. Preliminary operational experience in using the guidelines has been captured to improve the knowledge base in this area. ${ }^{38}$

Road safety and social sustainability. Under the STI, ADB began to steer its work at financing road safety projects which ensured the integration of safety into the design, construction, operation, and maintenance of all its transport projects. It has also been supporting efforts to build the capacities of DMCs in road safety management, safety performance measurement, and resource mobilization. In addition, its transport projects have become more inclusive, taking on more participatory approaches to project planning and implementation, integration of community-based initiatives, increased accessibility for the marginalized such as women and the elderly, and addressing issues such as HIV/AIDS and human trafficking.

In 2011, ADB introduced its first Road Safety Action Plan to guide its work on road safety.39 For the Association of Southeast Asian Nations region, plans for 10 countries were developed, through national workshops assisted by key road safety professionals and agencies, the private sector, and nongovernment organizations (NGOs). The plans focused on improvement of safety for vulnerable road users (especially pedestrians and motorcyclists) who form the vast bulk of traffic-related deaths and injuries in the Association of Southeast Asian Nations region. ${ }^{40}$ In addition, ADB has also increased its lending support and technical assistance on road safety for DMCs.

Logistics and cross-border transport. ADB has also began strengthening its initiatives that further connect countries for trade and partnership. Its subregional programs, such as the Central Asia Regional Economic Cooperation, the South Asia Subregional Economic Cooperation (SASEC), and the Greater Mekong Subregion (GMS) programs, have been active in developing transport corridors, mainly through the construction of roads and railways, to facilitate better trade market flows and promote economic cooperation and regional integration.

\section{PROGRESS TO DATE}

Implementation of the STI started in 2010 and will run until 2020. It has three phases. The first phase covers 2010-2011, where sustainable transport was mainstreamed in ADB operations, and new types of sustainable transport initiatives were explored and piloted in DMCs. The second phase, which runs from 2012-2015, involves the full implementation of new and enhanced sustainable transport operations. The third phase, which entails full implementation of the STI, covers 2016-2020.

36 ADB. 2013. Climate Change and Transport. Manila (August).

37 ADB. 2011. Guidelines for Climate Proofing Investments in the Transport Sector: Road Infrastructure Projects. https://www.adb.org/ documents/guidelines-climate-proofing-investment-transport-sector-road-infrastructure-projects

38 ADB. 2014. Climate Proofing ADB Investment in the Transport Sector: Initial Experience. https://www.adb.org/publications/climateproofing-adb-investment-transport-sector-initial-experience

39 ADB. Road Safety Action Plan. Manila. www.adb.org/sites/default/files/pub/2012/road-safety-brochure.pdf

40 ADB. 2011. Arrive Alive. ASEAN Regional Road Safety and Action Plan (2005-2010). Manila. http://www.adb.org/publications/arrivealive-asean-regional-road-safety-and-action-plan-2005-2010 
Change in the focus of transport investments. From 2010-2016, road upgrading and new construction comprised a major share of ADB lending for the transport sector. Sixty-seven percent (67\%) of ADB's investment portfolio for this sector went to roads-equivalent to $\$ 19.43$ billion in loans and grants. This percentage is actually a decline from the 2000-2009 levels, where lending for roads comprised $79 \%$ of ADB's transport portfolio.

ADB targets that, by the end of STI implementation in 2020, transport subsectors; namely, air, water, rail, and urban transport, will overtake lending for roads. By 2020, lending for roads is to be halved (to $42 \%$ of total transport lending) and lending for urban transport and railways is to have risen substantially (to $30 \%$ and $25 \%$ respectively).

Change in the way projects are designed. Aside from changing the direction of transport investments, ADB is also changing the way it designs its projects. To maximize the sustainability of its projects, ADB has introduced the Sustainable Transport Appraisal Rating (STAR), which carries a set of criteria against which the sustainability of a project is assessed. The criteria include economic objectives which details transport efficiency, quality and reliability, fiscal burden, employment, and wider economic benefits. It also carries social and environmental objectives. The social objectives include basic accessibility, affordability, inclusion (of vulnerable users), social cohesion and safety, and security and health, while the environmental objectives involve GHG emission reduction, transport-related emissions and pollution, preservation of the natural and built environment, and climate resilience. It also appraises risks, such as design and evaluation risk, implementation risk and operational risk. The STAR provides an overall sustainability rating for a project, ranging from highly sustainable to highly unsustainable.

Collaboration with a wider range of partners. In 2012, ADB committed its support to sustainable transport, together with seven other multilateral development banks (MDBs) at Rio+20. The MDBs pledged to provide, over the coming decade, more than $\$ 175$ billion of loans and grants to help developing countries build more sustainable transport systems. ADB, together with the MDBs, has already released $\$ 88$ billion to finance sustainable transport projects by the end of 2016. ${ }^{41}$ In addition, their projects are also shifting towards lower carbon modes, as they increasingly incorporate safety, climate change adaptation and mitigation, sustainable urban transport systems, and asset management into their projects. Beyond financing, ADB, together with the MDBs, further mainstreams sustainability through its initiatives on capacity-building, knowledge management, and policy dialogues.

\section{For further information:}

- Tyrrell Duncan, Technical Advisor (Tansport), Sustainable Development and Climate Change Department|tduncan@adb.org

- Ki-Joon Kim, Principal Transport Specialist, Sustainable Development and Climate Change Department|kjkim@adb.org

- Dongxiang Li, Lead Regional Cooperation and Integration Specialist, Economic Research and Regional Cooperation Department | dongxiangli@adb.org

41 https://www.adb.org/documents/progress-report-2015-2016-mdb-wg-sustainable-transport 


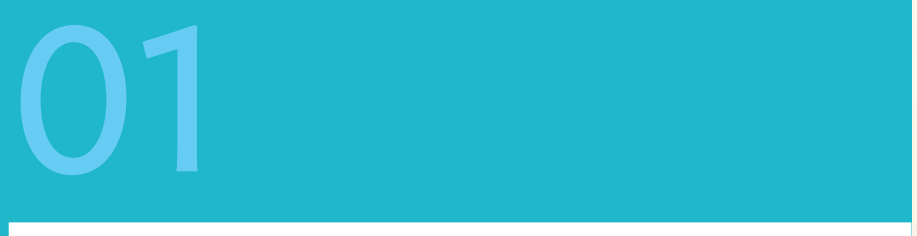

\section{WATERWAYS}

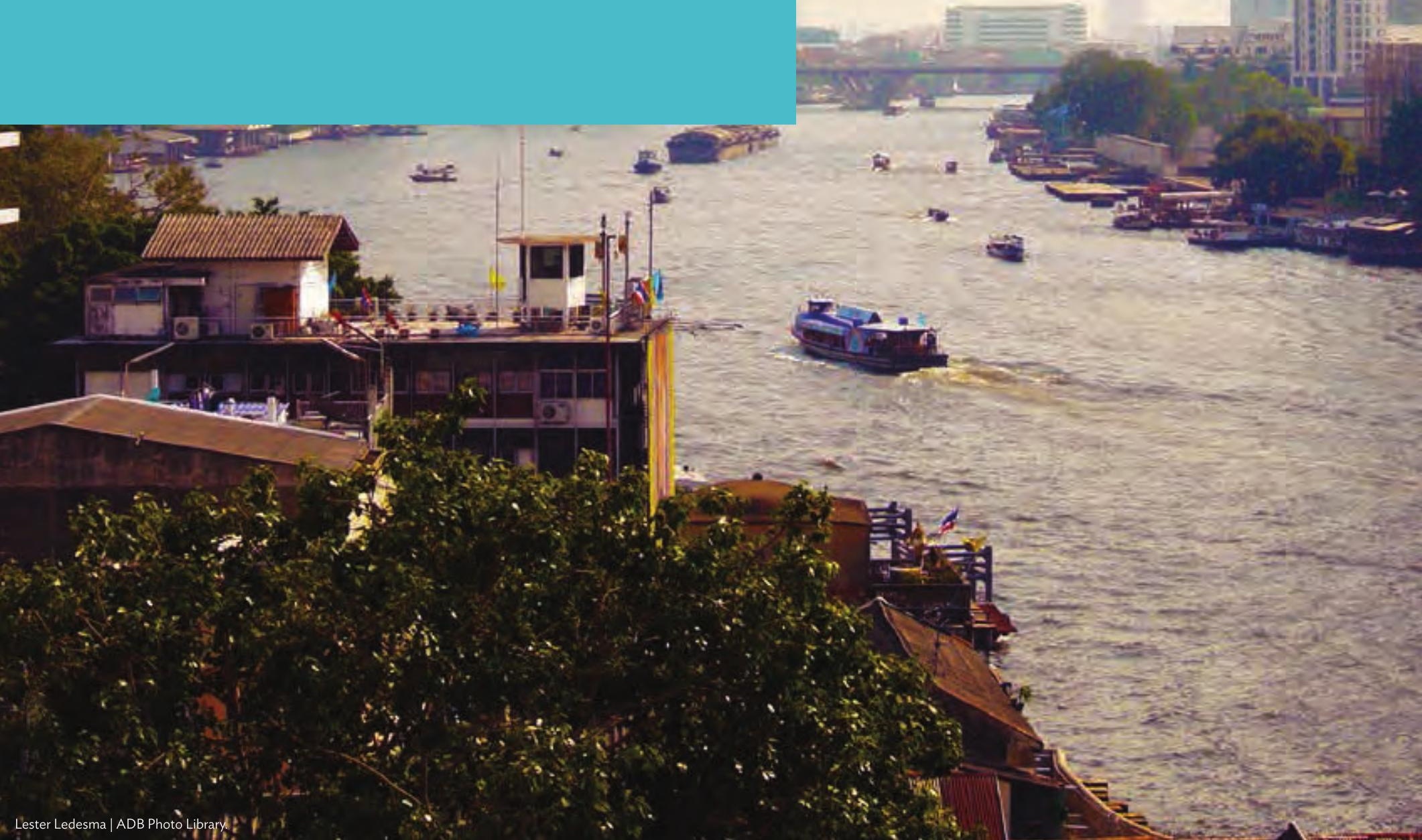




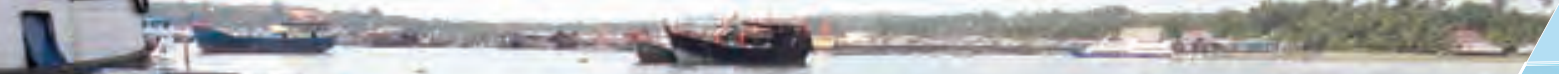

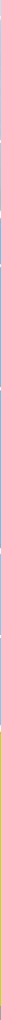

\section{THE River MORE TRAVeled:}

Navigable Inland Waterway in the People's Republic of China

In the past decades, investments in Inland waterway transport (IWT) infrastructure lagged behind road and rail construction in the the People's Republic of China.

The country is now prioritizing investment in its IWT network in recognition of its important role in the country's transport system.

- To enhance IWT, ADB helped finance the construction of a navigationcum-hydropower complex in Hunan province, inland ports in two cities, and landing stations in remote rural areas; and provided associated institutional strengthening.

- This initiative, ADB's first IWT project, will be completed by 2017. It will improve access to markets, reduce road and freight transport congestion, and cut down GHG emissions and pollution. 


\section{CONTEXT}

nland waterway transport (IWT) can be an efficient, cost-effective, and environmental-friendly option to move people and bulk commodities over long distances. By transporting people and goods over navigable rivers and canals, IWT reduces road and rail congestion, road crashes, pollution, emissions, and energy consumption.

The People's Republic of China (PRC) has long appreciated the importance of IWT. It has the world's largest IWT network, both in terms of length and freight volume. However, investments for the maintenance and modernization of IWT infrastructure have been overtaken by investments for highways and rail. Many ports are outdated, with no specialized berths and modern handling equipment.' This has kept IWT in the PRC from reaching its full potential. However, in recent years, the PRC has given renewed priority investment in IWT, recognizing it as an essential part of its transport system. ${ }^{2}$

The province of Hunan, which has one of the biggest IWT networks in the country, has been deeply involved in the PRC's efforts to improve IWT infrastructure. Hunan is a landlocked province with around 68.4 million residents. The Xiang River, one of the largest tributaries of the Yangtze River in the PRC, flows through six cities in the province. 773 kilometers $(\mathrm{km})$ of its total length of 969 kilometers pass through Hunan, making it the province's biggest river (footnote 1). It forms part of an intricate IWT network in the PRC, which has over 11,495 kilometers of waterways, 107 ports, and 1,880 berths.

\section{Hunan's IWT infrastructure} needed vast improvement. Only $6 \%$ of its waterways and berths can accommodate vessels with a carrying capacity of 1,000 tons. The limited depth of the river and its long rocky shoals have prevented safe year-round access by larger vessels. Traffic growth is also constrained by obsolete and insufficient infrastructure and loading

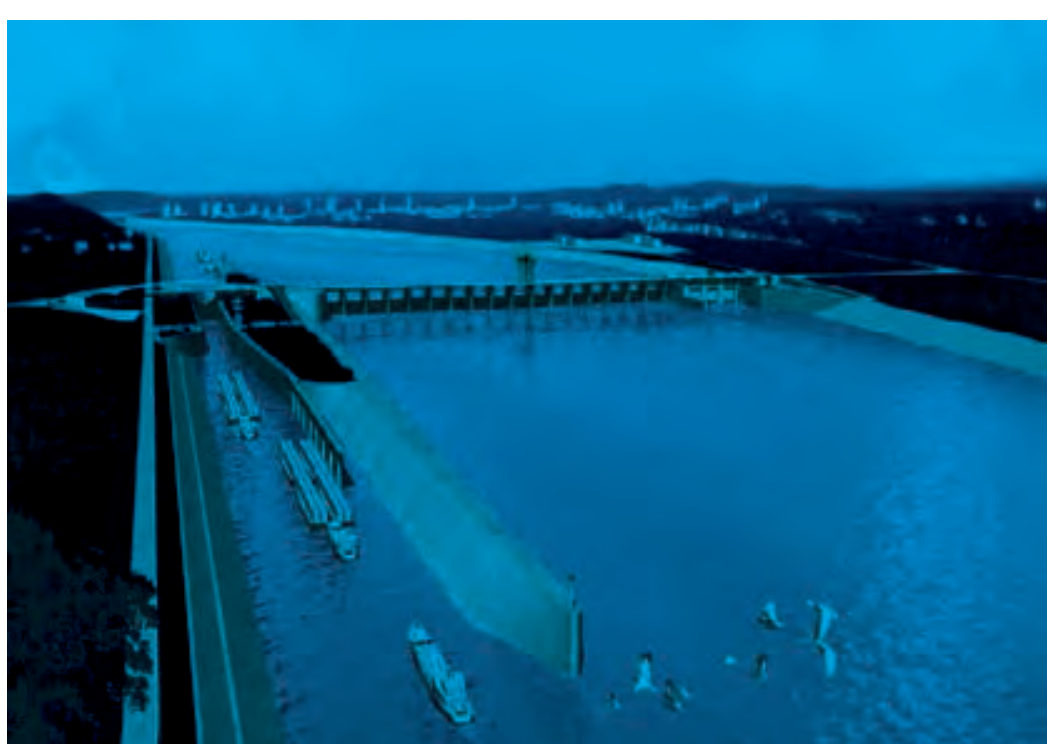

Planned arrangement of the navigatoin complex. Source: ADB Project Team.

1 ADB. 2012. Report and Recommendations of the President to the Board of Directors. Proposed Loan to the People's Republic of China.for the Hunan Xianjiang Inland Water Transport. Manila.

2 ADB. 2013. Features. Asia's Rivers and Canals: Inland Waterway Transport. http://www.adb.org/features/making-asia-flow-inlandwaterway-transport 
facilities in the river's ports. In 2009, the network carried only $10 \%$ of the overall freight transported in the province in terms of ton-kilometers.

To address these constraints, the PRC prepared the Xiang River Network Master Plan, which emphasizes IWT infrastructure development. Hunan has already executed several IWT infrastructure improvements in the river in line with the master plan, which aims to gradually make the Xiang River navigable year-round for barges of up to 1,000 deadweight tons (dwt) on its middle and upper reaches and for barges of up to 2,000 dwt on its lower reaches. Once the plan fully is implemented, the Xiang River will become one of the most important freight corridors in Hunan. ${ }^{3}$

In 2011, the PRC sought ADB's assistance in achieving its vision for the IWT network in Hunan. Together, they initiated a project - the Hunan-Xiangjiang Inland Waterway Transport Project - that aimed to construct a new navigation complex - the Tugutang Navigation Complex-with a ship lock capacity that can accommodate class III vessels, ${ }^{4}$ a run-of-the-river barrage to regulate river levels and flows, and an associated hydropower plant with a capacity of 90 megawatts (MW). In addition, this project will also construct cargo terminal berths and improve public landing stages, which will provide rural communities with improved access to river transport to different parts of the province and maximize the potential of industrial sites in the area.

The project, which is ADB's first IWT project, is an important element in the Xiang River Network Master Plan. Without the Tugutang Navigation Complex, prior investments given to enhance IWT facilities upstream of the river will be less beneficial.

\section{SOLUTIONS}

Barrage design and construction. A barrage is a structure that controls river level and flow. In this project, the barrage design considered several important dimensions. First, its design aims to raise water levels in the river so that class III vessels can navigate through it. Second, its design will integrate a hydropower plant with a total installed capacity of $90 \mathrm{MW}$. It was essential for the project to choose the best location for the barrage given its multipurpose nature. Geography, geology, river navigation, adjacent developments, and ease of construction were considered. The project chose from among three options: at the upper portion of the river in Hengnan County in Hunan, at a lower portion of the river in Chejiang Town, and at a middle site about 8.8 kilometers downstream from the upper portion of the river in Hengnan. The site in the upper portion of the river in Hengnan was ultimately chosen. In this area, the river channel is straight, providing ships adequate space to maneuver. In addition, this area is highly rural and has no environmentally sensitive sites, thus social and environmental impacts are minimized (footnote 3 ).

The project's barrage which forms part of the navigation complex, will have 17 sluice gates. Each gate will be 20-meter wide. A sluice gate is the barrage's "doors" - the mechanisms that can be opened or closed to control river flow. Each bay or opening will have metal radial sluice gates, which can be lowered or raised by pistons supported by bearings fixed to the pier walls. Each gate will be provided with an alternative source of power for backup in the event of main electricity supply failure.

3 ADB. 2011. Environmental Impact Assessment. People's Republic of China. Hunan Xiangjiang Inland Water Transport. Manila (July) www.adb.org/sites/default/files/projdocs/2012/43031-013-prc-eia.pdf

4 Class I vessels can carry 3,000 DWT; class II, 2,000 dwt; class III, 1,000 dwt; class IV, 500 dwt; class V 300 dwt; class VI, 100 dwt; and class VII, $50 \mathrm{dwt}$. 
The gates will be controlled and operated automatically, but will have a manual override option. Moreover, the barrage was designed to discharge a flow with a 1:50 year return period ${ }^{5}$ and verified as structurally able to withstand a catastrophic flood with a 1:500 year return period (footnote 3 ).

The barrage will include a run-of-the-river hydropower generation plant with a total installed capacity of $90 \mathrm{MW}$ and normal annual energy output of 358.2 million kilowatt-hours. The plant will have four turbine units, a power house, tailrace, transformer yard, and transmission lines to connect to the regional electricity grid on the west side of the barrage.

The construction of the hydropower plant was not a mere afterthought. Rather, the barrage was designed to be multipurpose, with hydroelectricity generation providing a revenue that would help the province recover the investment cost.

Ship lock. For vessels to pass the barrage, they go through a ship lock which is a chamber with gates at each end. Ship locks enable vessels to navigate through steep changes in the level of the river. The project's ship lock is located on one side of the river, and was designed to hold up to four 1,000-ton vessels. To fill the chamber, the ship lock has three inlet conduits where water regulated by the gates will flow. The chamber's walls were treated with manifold arrangement to minimize the whipping of turbulent waters on ships within the lock.

Ports development. As the navigation complex is projected to attract more freight traffic, ports in Hunan must also be enhanced. Cargo terminals in the project site only had main moorings and loading ramps for small vessels, with the biggest berth capable of receiving vessels with capacities of only 300 tons. The project sought to increase the port capacity of the province's IWT network. Engineering designs for two cargo terminals, each with a 100 m concrete berth, have been completed. The project will expand and improve the berths so that they can

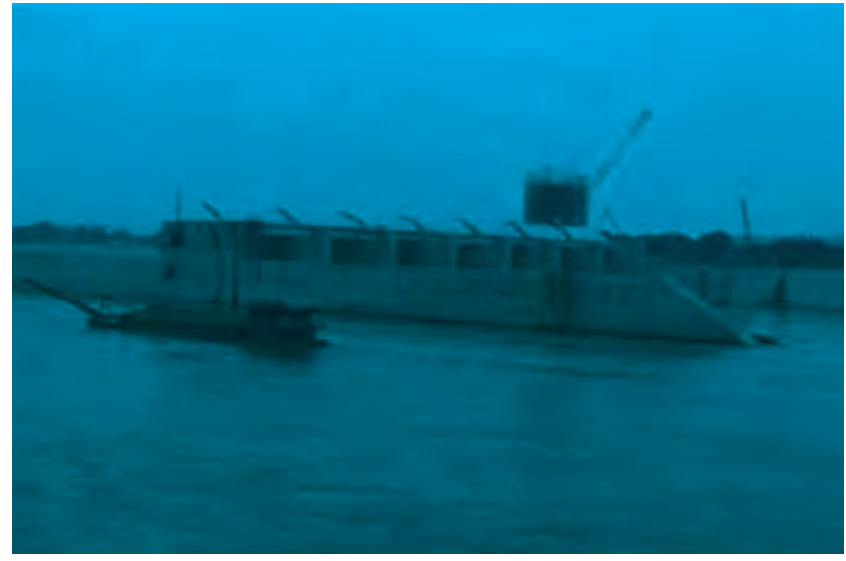

The shiplock under construction on the back of the river. Source: ADB Photo Library. handle vessels up to 1,000 tons. Aside from improving the berths, new facilities will be added to the terminals, such as open cargo storage areas, warehouses, and workshops, among others.

Fish pass. The project incorporated a fish pass into its design, to ensure that no fish and other aquatic animals will be carried into the hydropower turbines. The fish pass will be 774 meters long, and will provide a channel where aquatic animals can pass. In addition, important fish habitats will be identified and protected.

Institutional development. Alongside infrastructure development, reforms were also introduced in the institutions involved in IWT in the province. First, to improve coordination among the many institutions with responsibilities concerning the waterway, the province set up the Water Transport

5 1:50 return period refers to a river discharge flow that has a $0.02 \%$ chance of occurring in any given year. 1:500 return period refers to a flood event that statistically has a .02 percent chance of occurring in any given year. 
Development Committee to foster IWT development. Through the project, the province started introducing modern IWT management and support systems and provided trainings in monitoring, inspection and emergency response to the Hunan provincial department of transport, the Hunan Maritime Affairs Bureau, and the Hunan Xiangjiang Navigation Construction and Development Company. The project has also helped establish an IWT enterprise that will construct, develop, operate, and maintain inland waterway channels and associated assets in Hunan. The province, through the project, has also formulated an action plan for waterway promotion. This action plan includes setting incentives to encourage vessel modernization, shift from road transport IWT, and waste management.

\section{RESULTS}

When the complex is completed in 2017, Hunan will have the modern Tugutang navigation-cum hydropower complex.

This modern infrastructure will improve transport efficiency along the river as the navigation complex will be able to receive class III vessels, with a ship lock operation lasting no more than 50 minutes. This complex will be supported by 72 enhanced landing stations and 2 cargo terminals with wider berths, ready to receive more and largers vessels.

The navigation complex features a run-of-the-river barrage that regulates river levels and flows and a 90 MW hydropower plant. ${ }^{6}$ This additional energy can help the province meet its energy demand through its yearly power output of 363 gigawatt-hours of clean energy by 2017. This increased power supply through renewable energy will meet the electricity needs of about 300,000 households.

By producing clean energy, the project can help reduce GHG emissions. The project will help avoid approximately 290,000 tons of $\mathrm{CO}^{2}$ by generating electricity through hydropower rather than fossil fuels. It will further cut down emissions and pollution by reducing highway traffic congestion when cargo road transport shifts to IWT.

The project will further provide benefits to the people, especially the marginalized, as the extended cargo services can potentially generate more jobs while improving access to markets to the province which has about 637,000 poor rural residents and 273,000 poor urban dwellers. According to local officials, the project will create 50,000 jobs during its implementation. Women will also benefit from this, as at least $20 \%$ of employment generated during construction and operation will be allotted to them.

\section{LESSONS}

Using IWT as a transport option. When it comes to transport, roads and highways would often be the default responses to the need for connectivity. However, IWT, as proven by this project, can be an efficient, cost-effective green transport alternative, especially for cargo services. Through a welldeveloped IWT network, people and businesses will have a more reliable option to transport their goods.

6 ADB. 2012. Project Administration Manual. Hunan Xiangjiang Inland Waterway Transport Project. Manila (November). 
When using IWT, opportunities for interconnection can also be maximized, as shown in this project. Although the PRC already has an extensive IWT network, it recognized the need to modernize and extend its system. This project is part of a bigger network which starts at the Yangtze River, from which the Xiang River flows. To make its IWT more efficient, the country also developed the infrastructure of Xiang River and further extended it to remote villages.

Further, it is also important for IWT to have connection to road and rail transport. IWT can be an integral link in countries' logistics chain. An IWT network, when combined with a well-connected and efficient multi-modal transport network, will boost economic growth since it will enable comprehensive connectivity. Interconnection, however, requires detailed planning and interface arrangement. The project is currently studying port development options to ensure that access roads are wide enough, and will not run through densely populated areas to ensure safety and efficiency.

Optimal inland waterway transport design. Rivers and canals do not usually have uniform levels of depth and topography. In the case of the Xiang River, parts of it were too shallow and its shoals were rocky. This situation poses a big challenge to IWT since it limits the size and number of vessels that can be accommodated. This project overcame this hurdle. Instead of dredging the river to make it deeper, it raised the water level by building a barrage, with an added power plant component that will harness hydro energy. The barrage and reservoir ensure that river depth will be sufficient for vessel navigation even during dry season, and during the rainy season, they also act as a flood control mechanism since the barrage controls water level.

Institutional development. One neglected aspect in infrastructure development is the need for parallel activities for institutional development. The capacities of the multiple institutions must be expanded and upgraded so that they can easily handle the changes in infrastructure and the consequent results of these changes, such as increased traffic volume and increased demand for resources etc. Key activities in institutional reforms may include the establishment of a unit or interagency committee to oversee IWT implementation, the creation of a policy environment conducive to IWT, the upgrading of specific staff capacities and skills, and the creation of incentives to foster IWT.

Institutional development was made an integral part of this project. First, a waterway transport development committee was established in 2012 to promote IWT. An IWT development policy was also prepared, to be reviewed by the provincial government. In addition, the staff are currently being trained in vessel inspection and emergency response.

Importance of project preparatory studies and policy dialogue. Pressure from local or national government can sometimes induce hasty construction, without the benefit of a sound basis that extensive design, preparatory studies and policy dialogue can give. Particularly when ADB is entering a new field or subsector, initial sector studies play a key role in ensuring that ADB arrives at a sound basis for its eventual investment support.

The project used a two-stage project preparatory technical assistance where phase 1 covered sector assessment and identification of sector policy and institutional issues, and phase 2 covered project preparation. Phase 1 included workshops that facilitated consultation and policy dialogue between 
the government and ADB. Results from these activities highly influenced project design and implementation. The government initially wanted only a barrage to control water levels. Drawing on the findings of the project preparatory technical assistance and policy dialogue, port and rural access were added, extending the project's benefits to more rural households.

\section{Keywords:}

- Transport, inland water transport, IWT, water, river, hydropower, port, berth, sustainable transport, roads, bus, ship, ship lock, barrage, Hunan-Xiangjiang Inland Waterway Transport Project, PRC, People's Republic of China

\section{For further reading:}

- http://adb.org/projects/43031-013/main

- http://www.adb.org/projects/documents/hunan-xiangjiang-inland-waterway-transportproject-rrp

\section{For further information:}

- Cai Li, Unit Head, Project Administration, East Asia Department (caili@adb.org)

- Tyrell Duncan, Technical Advisor (Transport), Sustainable Development and Climate Change Department|tduncan@adb.org

- Ki-Joon Kim, Principal Transport Specialist, Sustainable Development and Climate Change Department|kjkim@adb.org

- Dongxiang Li, Lead Regional Cooperation and Integration Specialist, Economic Research and Regional Cooperation Department | dongxiangli@adb.org 


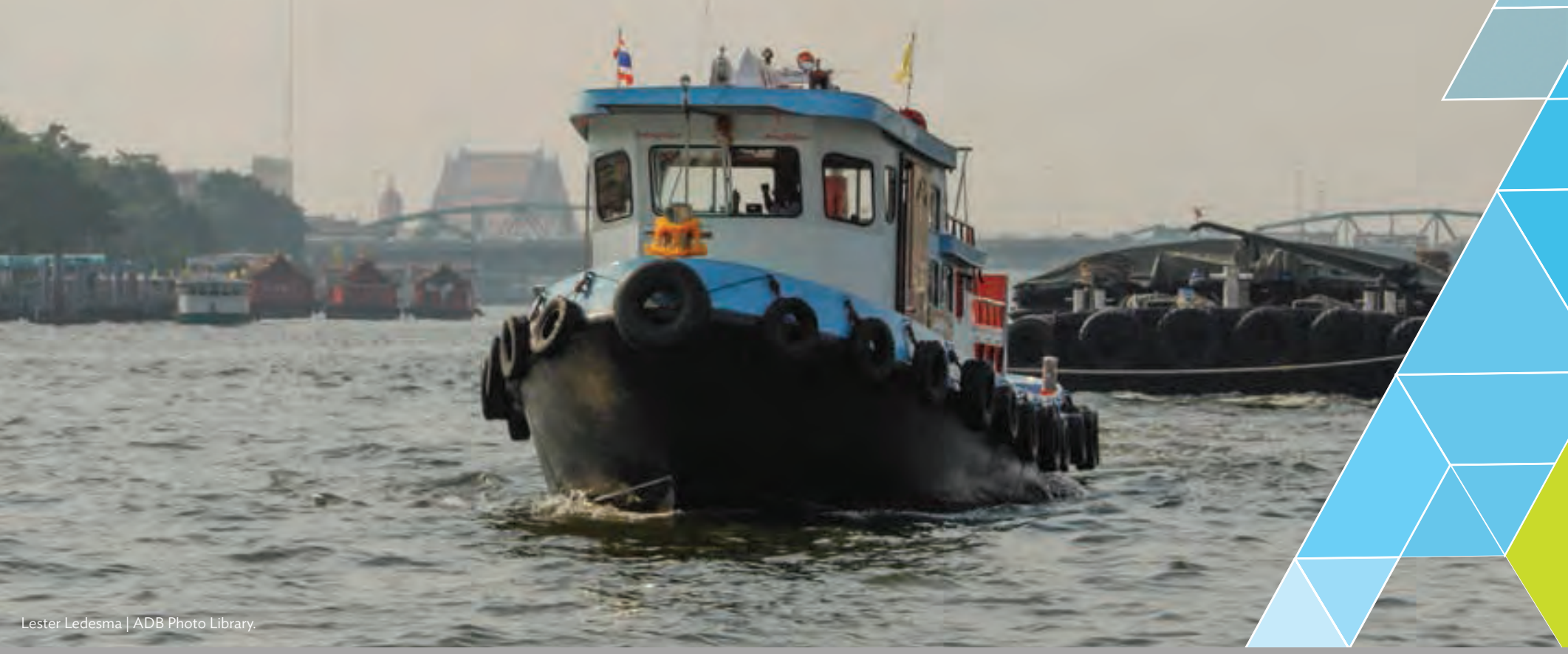

\section{FROM SHORE TO SEA:}

\section{LAND ANd Resettlement Issues in PORt DeVelopment in PAPUA New GUINEA}

- Upgrading of the congested Lae Port was crucial for Papua New Guinea to avoid further business losses, step up with international trade, and help boost the country's economy.

In 2007, ADB approved the Lae Port Development Project to decongest the port, stimulate industrial and commercial development, and promote international trade.

- About 4,000 project-affected people were adequately resettled and provided with livelihood skills and opportunities. New port facilities were built, including a tidal basin, a multipurpose berth, and terminal works to accommodate larger ships and more cargo.

In large infrastructure projects, the initial focus should be on the early resolution of land acquisition and resettlement issues. It would also be sensible to keep the project design simple and straightforward. 


\section{CONTEXT}

apua New Guinea's Lae Port was congested. The Lae Port, Papua New Guinea's largest, busiest, and most important port, had been operating at full capacity and could barely accommodate more ships, especially larger vessels bearing higher volumes of cargo. Upgrading the Lae Port was deemed crucial to avoid further business losses, scale up with international trade, and help boost the country's already sluggish economy.

The Lae Port is Papua New Guinea's center for imports and exports, and a hub for distributing cargo to and from the communities along the coastline and the country's inhabited islands. It also serves as a gateway linking the world market with a large hinterland comprising Morobe province and five resource-rich provinces in the Highlands. The Highlands is home to about 5 million of Papua New Guinea's 7.4 million people and represents half of the country's territory. Papua New Guinea's most significant road, the Highlands Highway, runs from Lae to Mount Hagen in the Highlands region, dispensing imports ranging from heavy machinery to food products and bringing the country's major export items to the Lae Port.

Approximately 50\% of the country's exports are shipped from the Lae Port. Since 1995, the volume of cargo handled at Lae Port has steadily increased by 142,000 revenue tons each year on average, at 12 tons of cargo for every twenty-foot equivalent unit (TEU). ${ }^{1}$ The port sought to adapt to the demands of container operations, but international ships had increased in size and in carrying capacity as had coastal trade vessels. By 2008, the Lae Port was operating at the limits of its capacity, with a throughput reaching 2.8 million revenue tons.

In 2007, ADB approved the Lae Port Development Project to assist the Government of Papua New Guinea in building new port facilities to increase cargo-handling capacity, promote trade and private sector investments, and contribute to economic growth. The Independent Public Business Corporation, ${ }^{2}$ which manages state-owned enterprises, oversaw project implementation.

The project was physically completed in 2015 and financially closed in 2016.
Project SNAPShot

Papua New Guinea: Lae Port

Development Project

Approval date: 2007

Amounts:

$\$ 100$ MILLION LOAN; \$89.12 MILLION ADDITIONAL FINANCING APPROVED IN 2011

Other:

$\$ 6$ MILLION - OPEC FUND FOR INTERNATIONAL DEVELOPMENT \$750,000 - COOPERATION FUND FOR Fighting HIV/AIDS IN ASIA AND THE PACIFIC (GRANT)

Total project cost: \$310.37 MILLION (INCLUDING GOVERNMENT'S FUND)

Borrower:

Government of Papua New GUINEA

Executing agency: INDEPENDENT PUblic Business CORPORATION

Geographical location:

Lae City, Morobe Province, Papua New Guinea

Transport project: WATER

Completion date: JUNE 2016

1 While the number of vessel calls has barely risen, overall traffic has grown by almost $40 \%$, and containerized traffic, by $80 \%$. Containerized cargo has been growing at more than $5 \%$ yearly and general cargo, at 2.5\%. ADB. 2007. Report and Recommendation of the President to the Board of Directors: Proposed Loan to Papua New Guinea for the Lae Port Development Project. Manila.

2 The Independent Public Business Corporation was established in 2002 as the trustee and manager of all the assets vested in the government's General Business Trust, including 23 state-owned enterprises and state equities. ADB. 2007. Report and Recommendation of the President to the Board of Directors: Proposed Loan to Papua New Guinea for the Lae Port Development Project. Manila. 


\section{SOLUTIONS}

ADB's Lae Port Development Project stimulated industrial and commercial development and promoted economic activities to sustain efficient regional trade.

\section{Land acquisition, resettlement, and livelihood program. ADB paid particular attention to land and resettlement issues in its policy dialogues with the government since land ownership in Papua New Guinea is a very sensitive and controversial issue, and resettlement was considered the biggest risk to the project. Expansion of the Lae Port called for the relocation of about 543 households, with a}

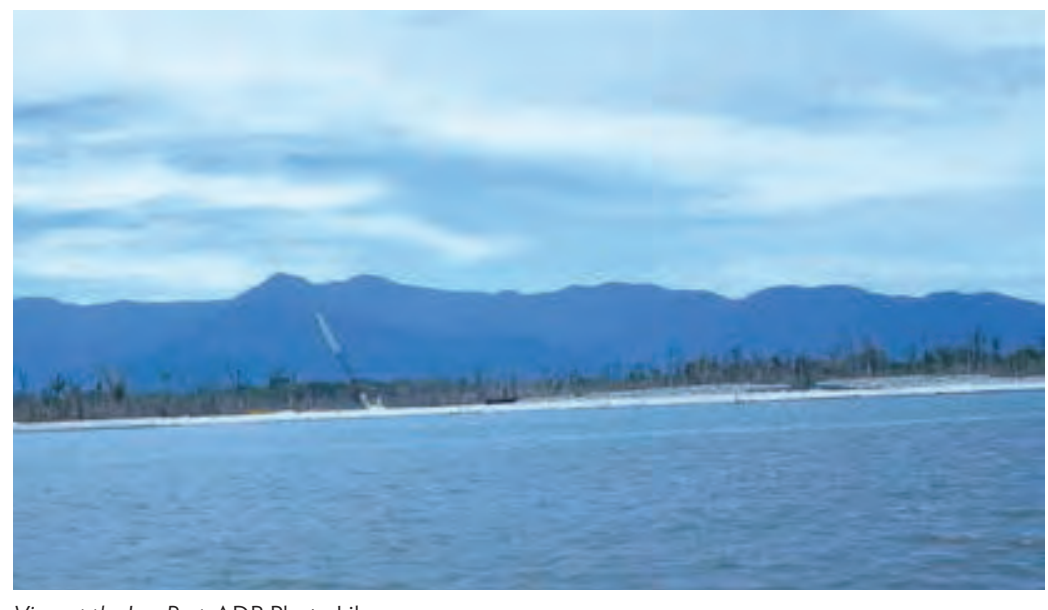

View at the Lae Port. ADB Photo Library. population of about 4,000, who were then occupying the project area. Project implementation was delayed for 2 years due to complex relocation negotiations with identified affected people living on the project site. The government had to ensure that the land required for the project was national land and that project-affected households were adequately relocated and compensated.

Extensive public consultations were conducted with government officials, the business sector, local communities, affected people, and international and national NGOs. The consultations were held to explain ADB's policies on the environment, resettlement, and procurement; increase project awareness; build project ownership; address technical, environmental, and social concerns; and identify appropriate project interventions. The stakeholders showed a keen interest in the project, the eagerness to benefit from it, and expressed concerns related to environmental and social issues. Their concerns were considered in the engineering design, the environmental management plan, the resettlement plan, the livelihood initiatives, and the project design. More than 1,000 stakeholders were consulted. The Japan Fund for Poverty Reduction, administered by ADB, provided a livelihood and social improvement program to complement the resettlement program and further ensure livelihood sustainability.

Construction of tidal basin and new port facilities. Instead of improving the existing port, it was less complicated to build new port facilities because the old terminal area was not large enough for efficient port operations. Also, the existing berths were built on a steep foreshore with increasing risks of geotechnical instability, heightening the financial risks of any improvement. Further, the new port facilities allow more berths to be built at a relatively low marginal cost, while opportunities to extend the existing berths were limited.

A tidal basin was constructed to extend the present port area into the large swamp northwest of the existing port. The project is the first phase of the tidal basin master plan and part of the blueprint drawn up by the Morobe Provincial Government to promote industrial development in Lae City. The tidal basin was constructed along with a multipurpose berth, buildings, container storage area, roads, 


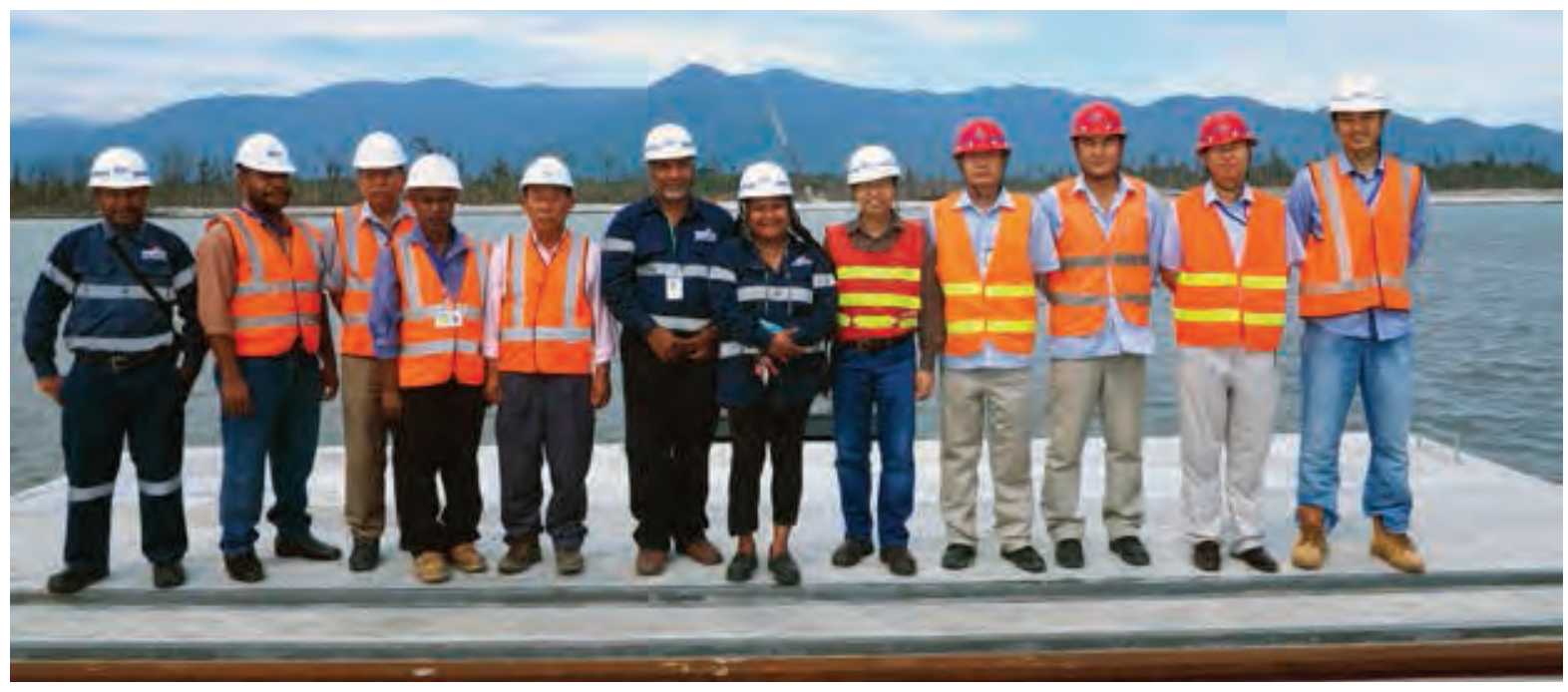

The Port's maintenance crew. ADB Photo Library.

drainage, water, electricity, and sewerage services. Rail-mounted quayside gantry cranes, heavy mobile cranes, and heavier handling equipment were also installed. The tidal basin and berth were designed to accommodate medium-sized cargo vessels.

All necessary geotechnical surveys and detailed engineering and design were completed during project preparation. Dredging and construction of the wharf and terminal have been packaged into one contract to ensure economy in administration and avoid interfacing problems. Project implementation schedules were conservative which enabled the contractors to progress ahead of time. The OPEC Fund for International Development cofinanced the civil works for the new port facilities, while the Australian Agency for International Development assisted the PNG Ports Corporation Limited in strengthening its institutional capacity to manage its capital and maintenance investment programs and improve port services.

Additional financing to cover cost increase. By 2010, project implementation preconstruction activities were mostly complete, but the total project cost had increased from $\$ 154.0$ million, as estimated in 2007 to the realized amount of $\$ 291.4$ million. This was because of high inflation in the construction sectors in the country. The Government of Papua New Guinea requested for additional financing from ADB.

In 2011, ADB approved the government's request for additional financing to cover cost-overruns and project design modifications. The total cost of the overall project increased by $\$ 137.4$ million, from $\$ 154.0$ million in 2007 to \$310.37 million in 2015 (102\%). The increase comprised $\$ 268.22$ million relating to civil and other works, $\$ 35.08$ million for contingencies, and $\$ 8.81$ million for financial charges. The cost of civil and related works increased from $\$ 109.4$ million in 2007 to $\$ 268.22$ million in $2015 .{ }^{3}$

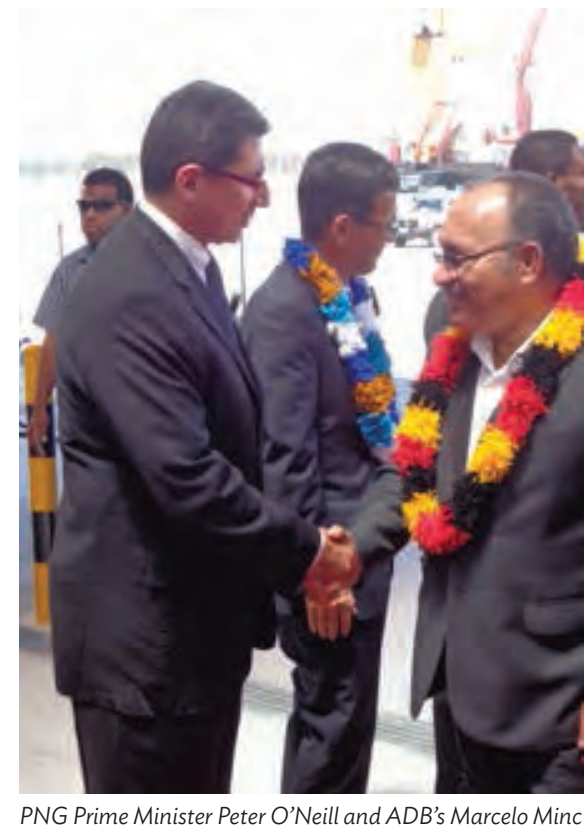
at the Lae Port Opeing Ceremony. ADB Photo Library.

3 The 2010 costs have been confirmed by the four conforming tender bids received and evaluated by the Independent Public Business Corporation, whereas the 2015 figures were derived at project completion. 
Increase in project cost was due to a combination of factors, including the global financial crisis that caused the depreciation of the US dollar against the kina by $17.8 \%$ between 2007 and 2010; 4 increases in the cost of structural steel and concrete and nonimported items including labor, materials, and energy; and design modifications to improve the technical quality of construction solutions. By 2010, the cost of the project as designed in 2007 increased by $\$ 62.46$ million. The government's request for additional financing met ADB's eligibility criteria and was approved in 2011. The project's technical feasibility was strengthened and higher-than-original economic and financial returns are expected. The government confirmed that the overall project is a nationally important strategic investment.

\section{RESULTS}

ADB's Lae Port Development Project transformed a swamp area that had negligible economic and financial value into an industrial park or free-trade zone, where the country's export products can be processed and take on added value before being exported.

Improved livelihood for displaced people. About 4,000 people were relocated from the project site, including the Labu people. Households were relocated to better land in the Malahang area of Lae. Each household was initially to be provided with a 700-square-meter residential area, a onebedroom house with reasonable living conditions, and relocation assistance. Due to constraints, for instance, acquiring land for housing, this was later replaced with a "cash assistance scheme." The canoe landing site of the Labu people near the port was rehabilitated.

Through the livelihood and social improvement program, 11 schools and 8 health facilities, community centers, a sports area, and an all-weather market in Malahang were established. Income-generating opportunities and livelihood-enhancement training for women and men were conducted. The training aimed to provide the project-affected people, including the Labu, with vocational skills to start small businesses, such as cocoa planting, inland fish farming, and mud crab fattening. A local NGO and local service providers were engaged to implement these livelihood training. Other interventions include assisting resettlers and the Labu in improving techniques in small-scale agriculture and animal husbandry and marketing of their products, assisting the Labu in community-based fish culture, and providing microcredits to affected people and the Labu.

New tidal basin, berth, and other port facilities. Expanding the capacity of the Lae Port required the construction of a 2,800-square-meter tidal basin in a swamp area northwest of the present port facilities with a dredged depth of 13 meters below chart datum. A multipurpose berth, 240 meters long and 45-50 meters wide, was also built with provision for extension by another 150 meters without incurring dredging cost. The tidal basin and berth were designed to accommodate vessels with an overall length of 200 meters, beam of 32.2 meters, and fully laden draft of 12 meters, including "Panamax" container vessels of a maximum 50,000 deadweight tons. A container yard of 12.7 hectares was provided behind the wharf structure. The expanded port also features an administration building, cargo shed, navigation aid towers, infrastructure services, and security fencing, port link road pavement, and a diversion channel for the Mai Creek.

4 This depreciation has increased the overall project cost by $\$ 38.17$ million. ADB. 2007. Report and Recommendation of the President to the Board of Directors: Proposed Loan to Papua New Guinea for the Lae Port Development Project. Manila. 


\section{LESSONS}

ADB's Lae Port Development Project offers lessons on implementing port development projects that involve large and long-term infrastructure investment that necessitates sustained engagement with government and other project partners.

Target early resolution of land acquisition and resettlement issues. The strong policy dialogues between $A D B$ and the government during project preparation focused mainly on resettlement arrangements and monitoring. Land acquisition and resettlement required comprehensive discussions with various stakeholders before project implementation. The land issue was extensively studied, and the resettlement plan and a livelihood and social improvement program were formulated in an equitable way to minimize social risks. The continuous policy dialogues helped resolve relocation issues and enhanced project ownership by the government.

Keep the project design simple and focused. Large, ADB-financed, infrastructure projects in Papua New Guinea have been prone to substantial delays. A complex design and implementation arrangement covering wide sectors often leads to project delays and implementation problems. The construction of the Lae Port was simple and straightforward in design, and was focused on crucial physical infrastructure. Further, the port is in a confined space, allowing effective risk management and environmental impact mitigation activities. A design-and-build package was included in the contractor's scope of works, which was proven effective and efficient in delivering the infrastructure.

\section{Keywords:}

port, water transport, tidal basin, shipping, Lae Port Development Project, Papua New Guinea

\section{For further reading:}

- Project web page: http://www.adb.org/projects/40037-013/main

- Project web page (additional financing): http://www.adb.org/projects/40037-043/main

- Project preparatory technical assistance: http://www.adb.org/projects/40037-012/main

- Livelihood and Social Improvement: http://www.adb.org/projects/40037-022/main

\section{For further information:}

- Muhammad Amir Ingratubun, Principal Infrastructure Specialist, Pacific Department | mingratubun@adb.org

- Tyrrell Duncan, Technical Advisor (Transport), Sustainable Development and Climate Change Department|tduncan@adb.org

- Ki-Joon Kim, Principal Transport Specialist, Sustainable Development and Climate Change Department | kjkim@adb.org

- Dongxiang Li, Lead Regional Cooperation and Integration Specialist, Economic Research and Regional Cooperation Department |dongxiangli@adb.org 


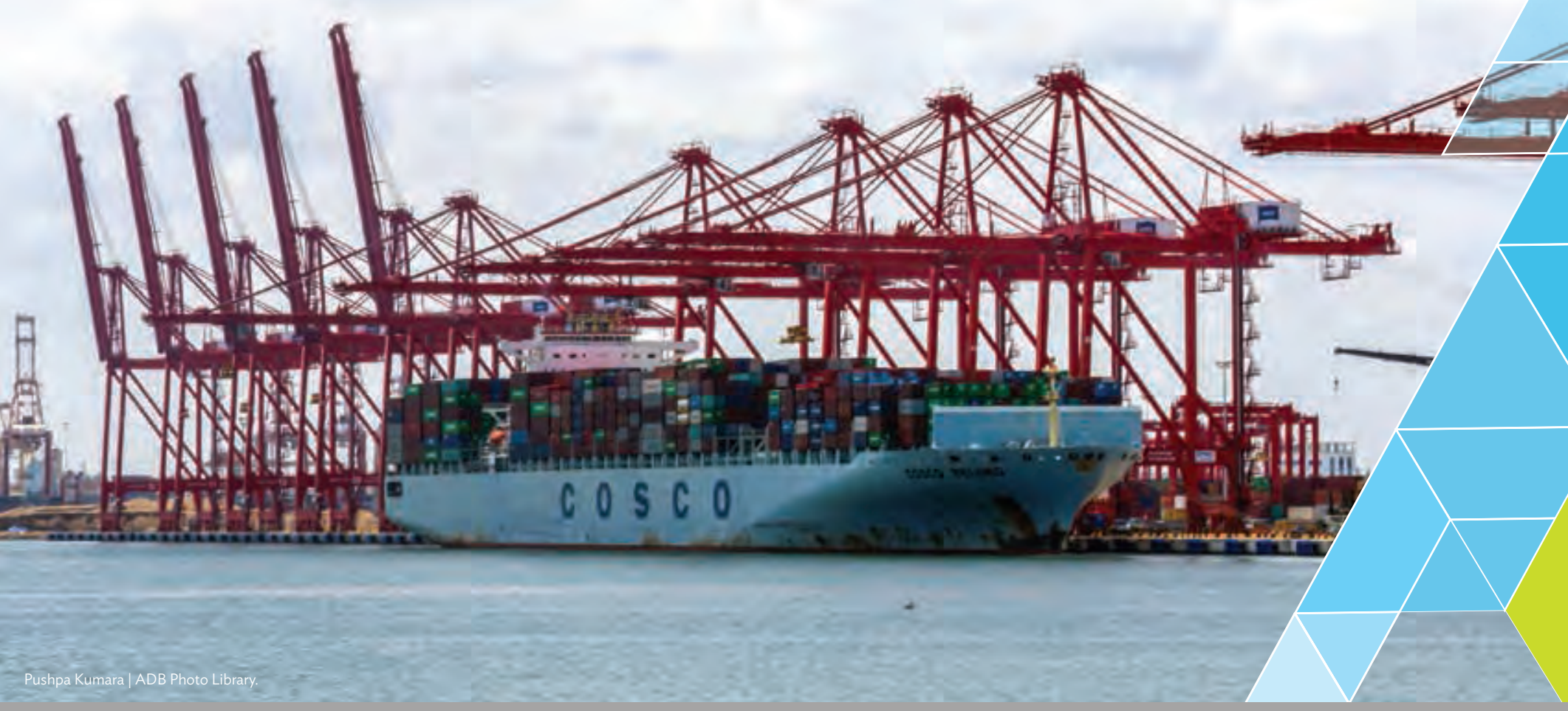

Mega Port for Mega Ships:

AtTRACTINg PARTNeRS FOR PORT EXPANSION IN SRI LANKA

Prior the project, Colombo Port had suffered market losses due to insufficient capacity and low efficiency. Upgrades were necessary to maintain its position as a transshipment hub in the South Asian region.

In 2007, ADB approved the Colombo Port Expansion Project to upgrade the Port of Colombo through a public-private partnership. The government implemented the dredging and breakwater construction, which could accommodate three new container terminals. The first terminal was implemented by the private sector through a Build-Operate-Transfer contract.

The project increased port capacity and enhanced efficiency, thereby enabling it to accommodate the new generation of mega shipping vessels.

As one of the largest port sector investment in Sri Lanka, the project not only cements Sri Lanka's position as an important international trade gateway in South Asia, but has become a successful model of public-private partnership in the region's port sector. 


\section{CONTEXT}

B usiness suffered from insufficient capacity and low efficiency at the Port of Colombo. Colombo Port was the natural transshipment hub port for the South Asian region. In 2005, container traffic volume at Jaya Container Terminal accounted for more than $90 \%$ of the Sri Lanka Port Authority's revenues. About 70\% of the containers handled in Colombo Port were transshipment containers, of which 75\% were for the Indian subcontinent (ISC) market and 25\% for the West African market. Between 1998 and 2002, however, Colombo Port's share in transshipment of ISC cargoes declined from $52 \%$ to $45 \%$ of the total even as the ISC transshipment market grew at an $8 \%$ annual rate. The loss in market share accounted for a stagnation of overall container traffic volume at Colombo Port during this period. This occurred mainly because the fundamentals of the market changed and Colombo Port did not adapt. Colombo Port could not offer the additional operating capacity needed to compete for the ISC transshipment market or the depth required to berth the latest generation of container ships.

The ships that could not be accommodated by the Colombo Port started to turn to alternative ports such as the Nhava Sheva port in India. Previously serving only smaller feeder vessels, the Nhava Sheva port stepped up with improvements in port efficiency and the construction of a private terminal in 1999. New ports, Salalah in Oman, and Port Klang and Tanjung Pelepas both in Malaysia, had also emerged to take a piece of Colombo's transshipment traffic. Stringent pricing by the Sri Lanka Ports Authority also turned away many shipping lines, while the Port of Singapore and Port Klang offered more competitive prices. Low productivity within the Colombo Port also contributed to the port's decline.

In 2001, port efficiency at the main Jaya Terminal improved with the commencement of operations and increased competition from the privately-owned South Asia Gateway Terminal. However, the lack of capacity and low port efficiency still constrained Colombo Port from sustaining its strategic position as the transshipment port of choice, despite its strategic geographical advantage.

To recapture market share and remain a transshipment port, Colombo Port would need to develop additional container berths with the required depth to address these capacity and depth infrastructure constraints. In 2007, ADB approved the Colombo Port Expansion Project to upgrade the port through public-private partnership.

The public sector component of the project included harbor infrastructure works, establishment of a new marine operations center, relocation of a submarine oil pipeline, provision of navigational aids, and construction of shore utilities. Harbor infrastructure works required dredging and breakwater construction, which was implemented by the Sri Lanka Ports Authority. The construction of breakwater infrastructure was completed on time in 2012.

The private sector component of the project included the development of the first private sector operated terminal. The Colombo International Container Terminals was awarded a 35-year BuildOperate-Transfer concession to design, construct, and manage the first container terminal - the 


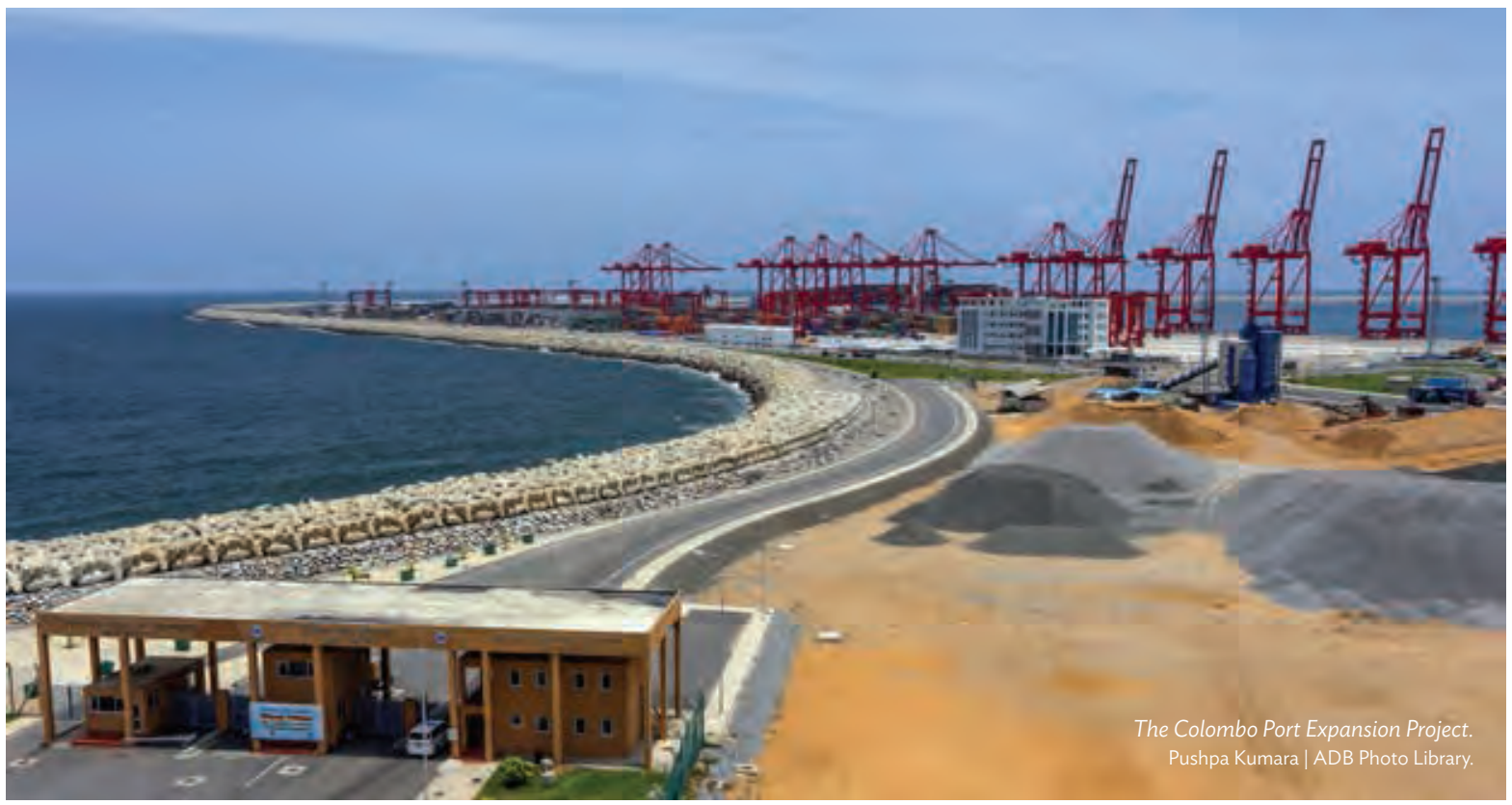

South Container Terminal-on the newly constructed breakwater. The South Container Terminal commenced operations in 2014. The East Container Terminal is currently under development. West Container Terminals is envisaged to be required in the longer term.

For the Government of Sri Lanka, an efficient port system is the key to improving the country's competitiveness and attracting investment. The port expansion project enhances efficiency, increases competitiveness, and will attract more ships to Colombo. The upgraded Colombo port is expected to not only bring more foreign exchange to the country and boost the tourism industry, but also facilitate the development of industries such as ship chandlery, ship repair, and bunkering activities. The port will also boost the country's textile industry, which accounted for about $40 \%$ of its exports in 2012.

\section{SOLUTIONS}

The Colombo Port Expansion Project enhanced Sri Lanka's position as a strategic transshipment hub. The PPP approach not only brought about significant efficiencies in delivery, it was able to bring in tremendous financial leverage. The public sector investment of $\$ 400$ million (including $\$ 300$ million of ADB loan) brought in $\$ 500$ million of private sector investment for the development of the first container terminal.

Shared financing. The project structure was successful in leveraging significant private sector financing to develop the future terminals at the port. During project preparation, the initial cost of the South Container Terminal was estimated at \$301 million. However, at its completion, the concessionaire is estimated to have invested approximately $\$ 500$ million for the construction of the South Container Terminal. The increase in cost is likely attributed to the increase in cost of inputs and delivering on an expedited schedule. The terminal was completed 32 months ahead of original schedule. The first phase of $400 \mathrm{~m}$ of terminal commenced operations on 5 August 2013, delivering additional capacity of 0.8 million twenty-foot equivalent units (TEU) per annum. The remaining 


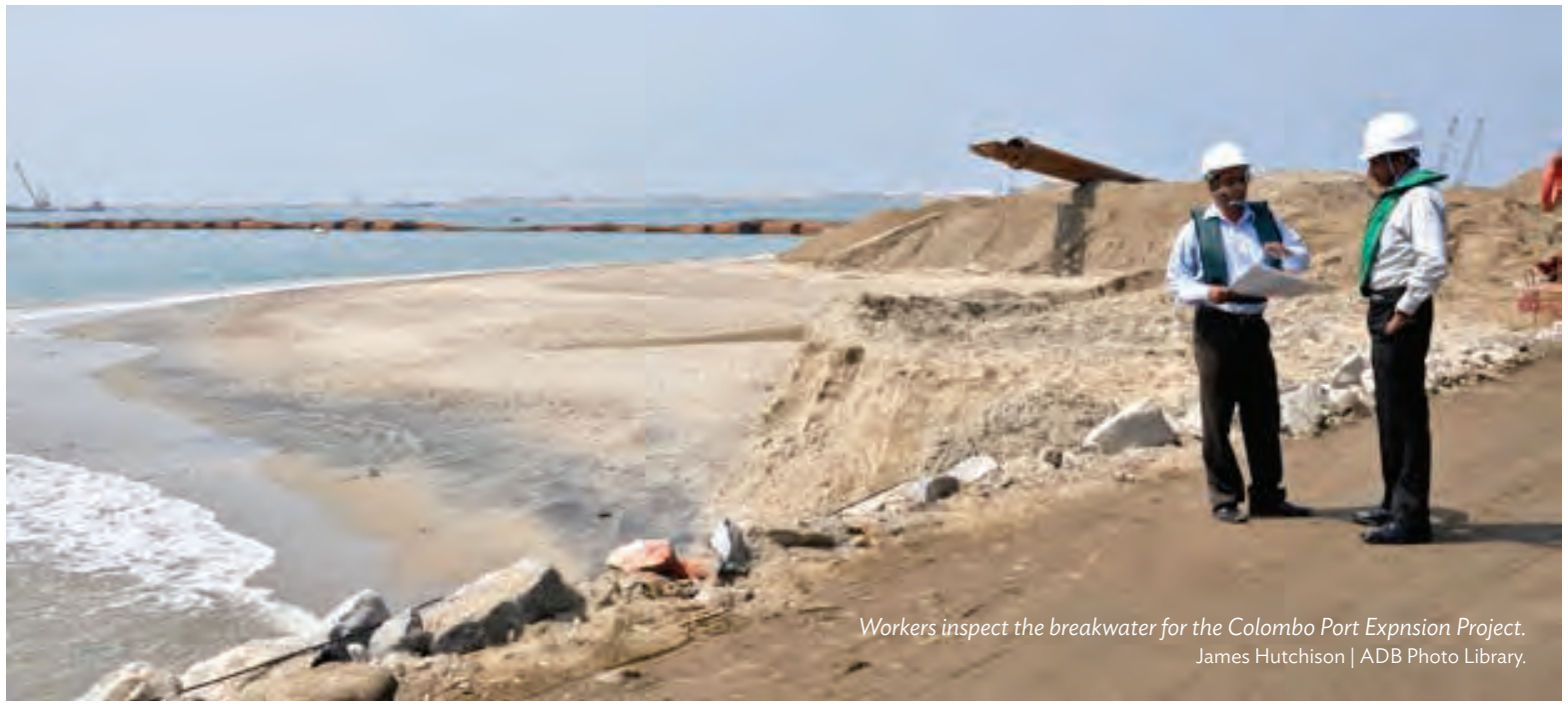

800 million was completed and became fully operational by April 2014, adding further capacity of 1.6 million TEU per annum.

The investment in Colombo port constitutes one of the largest foreign direct investments in Sri Lanka and one of the first large-scale public-private partnerships in the region in its time. At the time of project design, the cost of construction of the remaining two terminals - the East Container Terminal and West Container Terminal-were estimated at \$301 million and \$324 million respectively. When fully opened, the three terminals will add a combined container handling capacity of 7.2 million TEUs per annum to the existing port operations.

Single contract packaging. The harbor infrastructure works was packaged as a single contract, which attracted good quality and experienced contractors. The upgraded port has a depth of 18 meters and has a two-way harbor access channel about 9,000 meters long, 570 meters wide, and 20 meters deep. The port is equipped with a new navigation control tower facility, marine navigation aids, and vessel traffic management system. Some 6.4 kilometers of access roads was also constructed.

The project reclaimed 7 hectares of the sea by dredging 15 million cubic meters of sand from the main channel. About 5 million cubic meters of rock material was used for the 6.4-kilometer-long breakwater, which features 34,500 core-locs and a 9-to-11-meter high wave wall to protect the port from erosion brought by strong waves and adverse weather conditions. The project was designed to accommodate three new terminals, each with additional capacity of 2.4 million TEUs, thereby increasing the overall container-handling capacity by 7.2 million TEUs.

However, the lack of dredging equipment and unfavorable sea conditions during the monsoon period caused some delay during project implementation. Close monitoring and review by the engineers from both SLPA and the contractor prompted adjustments to the work planning and program to make up for the delays as much as possible. The contractor overcame multiple difficulties and successfully completed the majority of works within schedule. The contract was extended by 6 months to complete minor building works. Overall, project implementation of the public sector component was considered successful. The actual construction period was about 4 and a half years, which is merely half a year more than estimated during appraisal. 


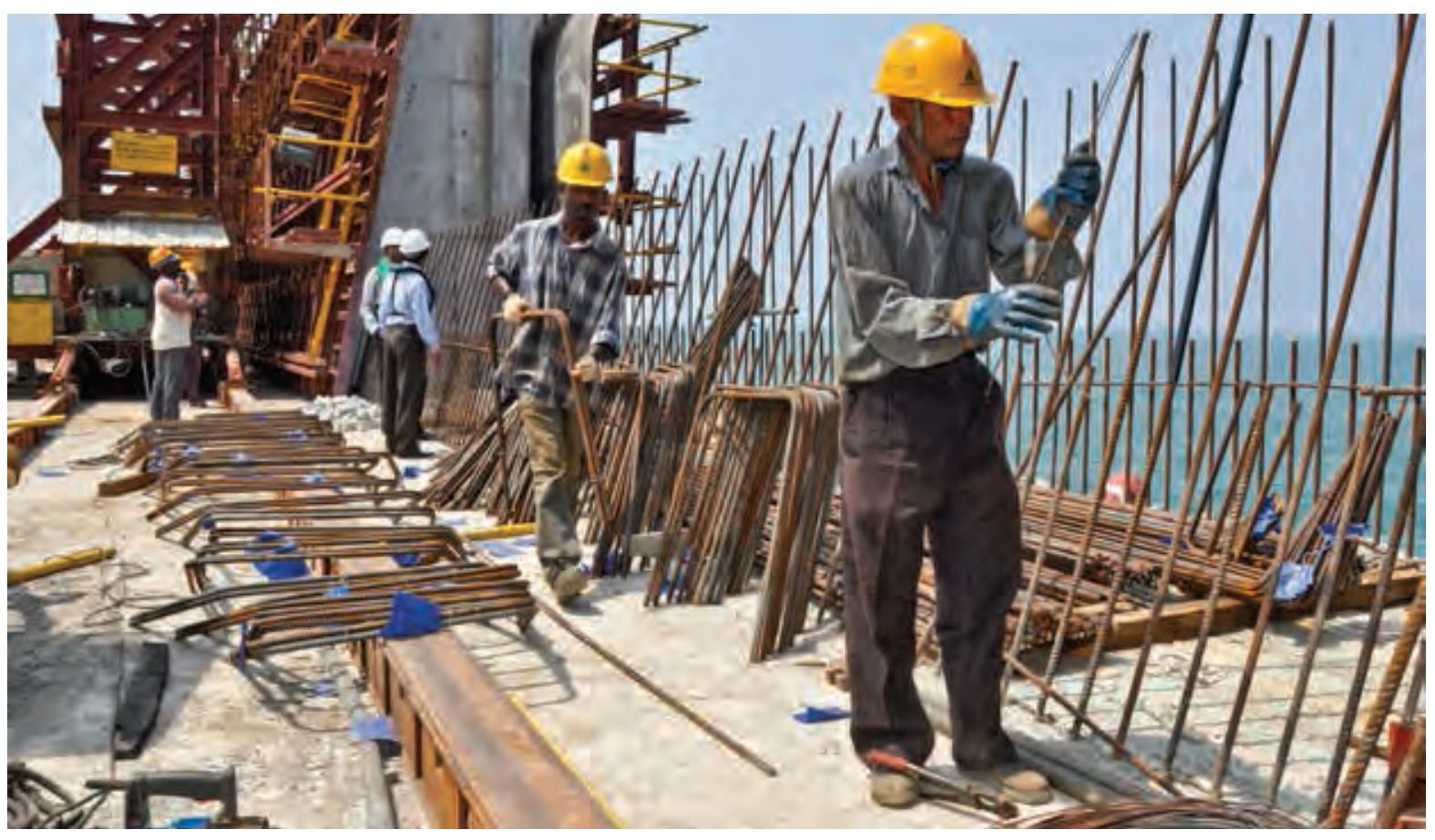

Construction works at the Colombo Port Expansion Project.

James Hutchison | ADB Photo Library.

\section{RESULTS}

The Colombo Port Expansion Project increased the port's capacity to accommodate the new generation of mega vessels and enhanced the port's operational efficiency.

Increased port capacity. In 2006, prior to the project, the Colombo Port's total container-handling capacity was estimated at 3.3 million TEU. Since the construction work was completed and the South Container Terminal began operations, the port's capacity increased to 8.1 million TEU in 2015 and is expected to reach 10.5 million TEU when the other terminals become operational.

In 2011, the port was operating almost at its maximum capacity, handling an estimated 4.3 million TEU, while its maximum capacity was about 4.5 million TEU. At the time, the South Container Terminal had not commenced operations. The Sri Lanka Ports Authority estimated a capacity shortfall of about 0.3 million TEU by the end of 2012 and at least 0.8 million TEU by 2015. To mitigate the impact on Colombo's competitive position, the Sri Lanka Ports Authority developed part of the East Container Terminal as an interim measure to address the urgent capacity situation.

The South Container Terminal commenced operations in 2013. During its first year of operation, the largest vessel that called on the South Container terminal was a 14,000 TEU vessel - a positive indication that Colombo Port was still being considered as an important transshipment hub in the region. With the port's enhanced capacity, freight rates could be reduced to make the port more competitive and attract more ships. Moreover, the port is able to accommodate the new 18,000-container capacity ships, which could potentially bring even greater logistical efficiencies and cost savings. 


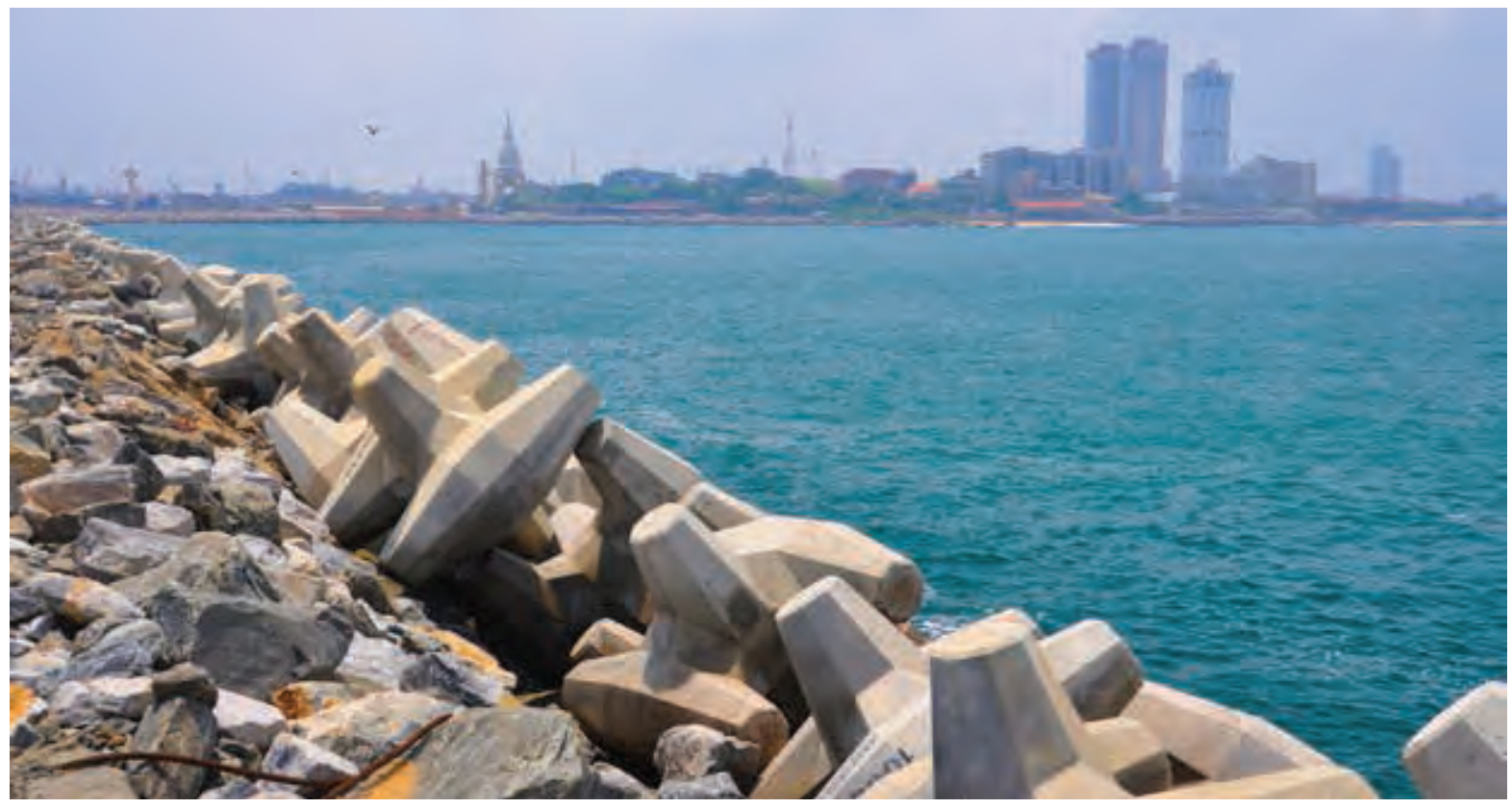

34,500 core-locs were used for the 6.4 kilometer-long breakwater. James Hutchison | ADB Photo Library.

Enhanced port efficiency. Colombo's efficiency levels are among the highest in the region. While some $70 \%$ of the cargo that passes through Colombo Port is for transshipment, local exports include tea and garments. Imports are largely large appliances, consumer electronics, and vehicles. Both top importers, such as supermarket chain owner the Cargills Group, and exporters, such as tea giant Dilmah, rely on the port's efficiency. In its first year of operations in 2014, the South Container Terminal's total throughput was 686,636 TEU. ${ }^{1}$

As the demand for relay transshipment increases, the South Container Terminal offers a strategic link between the Indian Subcontinent and the lucrative Asia-Europe shipping route. The new facilities at the South Container Terminal make it one of the very few ports in the South Asian region with a deep-water terminal that can accommodate the newest breed of the world's largest container ships, providing greater cost efficiencies to mainline shippers.

Higher efficiency and faster delivery times will attract larger vessels and higher volume of trade. This would enhance Sri Lanka's competitiveness in international trade and will draw potential investment in the country for setting up new manufacturing and distribution centers.

\section{LESSONS}

The Colombo Port Expansion Project offers lessons in implementing large-scale infrastructure projects through public-private partnership.

Finding the right formula for public-private partnership. Determining the optimal balance of public and private sector participation was a crucial part of project structuring and preparation. The government applied a public-private partnership landlord port model, where the public sector

$1 \quad$ ADB. 2013. Project Result and Case Studies: Sri Lanka Shipping and Maritime Transport. http://www.adb.org/results/srilanka-shipping-and-maritime-transport 
would deliver the basic breakwater infrastructure and the private sector would deliver two of three container terminal facilities to be accommodated by the new breakwater. This approach brought significant efficiencies in project delivery and has resulted in tremendous financial leverage.

Given the large-scale and complex in nature of the project, it was important to bring in quality consultants and contractors. Continuation of services from the main design consultants to provide construction supervision not only reduced the time for procurement but also resulted in minimizing liability risks and disclaimers of responsibility. Realization of the full project benefits was contingent upon the public and private sector components being well-coordinated and implemented as planned.

\section{Sustaining the environment of healthy competition and private investor confidence.}

Continued and nurtured partnership with the private sector would allow for sustained and efficient port operations. The Sri Lanka Ports Authority has been advised to continue implementing and monitoring the environmental management plan, which covers the operation of the South Container Terminal. The Ministry of Ports, Shipping, and Aviation has also been advised to continue the functions of the Advisory Committee to monitor and address any grievances in unfair competition.

\section{Keywords}

port, transshipment hub, public-private partnership, private sector finance, water transport, Colombo Port Expansion Project, Sri Lanka

\section{For further reading}

- Project web page: https://www.adb.org/projects/39431-013/main

- Sri Lanka Shipping and Maritime Transport: http://www.adb.org/results/sri-lanka-shippingand-maritime-transport

- Colombo Port Upgrade: http://www.adb.org/news/videos/colombo-port-upgrade

\section{For further information}

- Alexandra Pamela Chiang, Transport Specialist, Pacific Department | apchiang@adb.org

- Tyrrell Duncan, Technical Advisor (Transport), Sustainable Development and Climate Change Department | tduncan@adb.org

- Ki-Joon Kim, Principal Transport Specialist, Sustainable Development and Climate Change Department|kjkim@adb.org

- Dongxiang Li, Lead Regional Cooperation and Integration Specialist, Economic Research and Regional Cooperation Department |dongxiangli@adb.org 

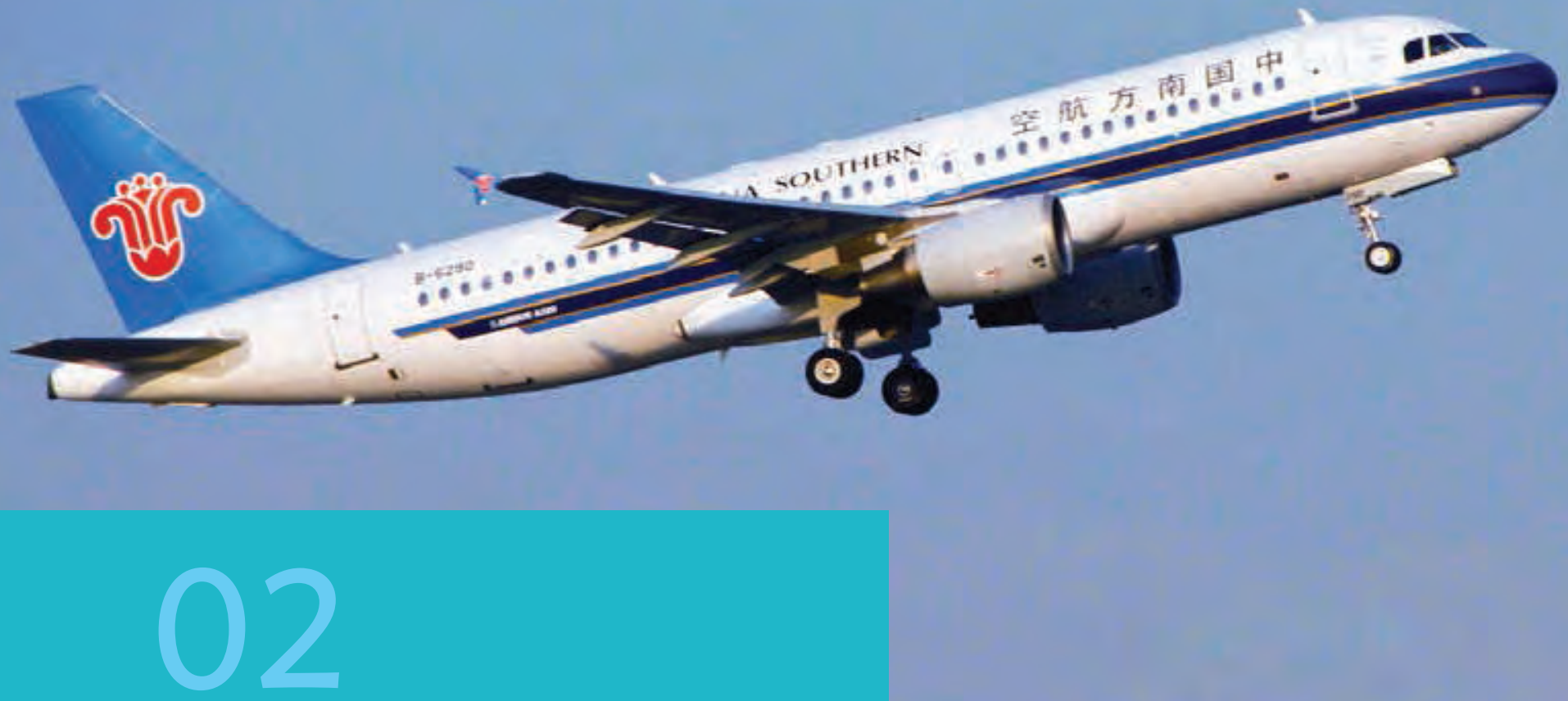

\section{UP IN THE AIR}




\section{CONTEXT}

$\mathrm{B}$

hutan upgraded its domestic air transport system to provide safe flights and connect the country's isolated regions.

Navigating flights through the high mountain peaks of the eastern Himalayas, where Bhutan is nestled, can be challenging, even for the more experienced of pilots. Bhutan's harsh geography is also the cause of disconnectedness and isolation among the many communities settled in either the low lush valleys or the high upland areas. The development and upgrading of Bhutan's domestic air transport system enhanced connectivity among the regions, which is expected to contribute to economic growth and the achievement of the country's Gross National Happiness agenda.'

Bhutan's sparse population, about 700,000 people, live in 38,000 square kilometers of land. Many isolated communities have limited access to basic social services, including health and education.

While a functioning road network is in place, land travel can also be risky, as landslides on Bhutan's narrow and winding mountain roads are frequent. Transport fees are high and road construction and maintenance require considerable financing from the government. Bhutan has no seaports, trains, or inland river or waterways transport.

By plane, landlocked Bhutan is accessible only from Bangkok, Dhaka, Kathmandu, Singapore, and a few choice cities in India. Flying to Bhutan means landing at Paro International Airport, the only airport that caters to international flights. Located in the Paro Valley in the western region near the capital Thimpu, Paro International is considered "one of the most challenging airports to fly into"; the descent into the deep valley, an "exhilarating experience." ${ }^{2}$ Since opening the country to the world in the 1980s, Bhutan's air transport sector has enjoyed a clean safety record, with zero fatalities. The Government of Bhutan intends to keep it this way because just one incident can have dire effects on Bhutan's tourism industry and the country's economy.

Within Bhutan, varying weather conditions - snow, monsoon rains, and strong winds at high altitudes-bring additional flight risks to international tourists and domestic passengers alike. Hills as high as 4,800 meters and high winds at certain times of the year restrict aircraft operations to only about 4-6 hours in the daytime. Flights are operated entirely manually. Delays or cancellations due to inclement weather are frequent, and only two airlines are allowed on Bhutan's airspace.

In 2012, ADB approved the Air Transport Connectivity Enhancement Project to assist the Government of Bhutan in jumpstarting the development of the local air transport industry and increasing air connectivity. The project, funded through a small grant, is ADB's first support for air transport in Bhutan and provides the Department of Civil Aviation a first-hand experience in

1 Gross National Happiness is Bhutan's philosophical and holistic approach to sustainable development that emphasizes noneconomic aspects of well-being. Coined in the 1970 s by His Majesty the Fourth King of Bhutan Jigme Singye Wangchuck, the concept is grounded by four pillars: good governance, sustainable socioeconomic development, cultural preservation, and environmental conservation. http://www.grossnationalhappiness.com

2 From the Bhutan Department of Civil Aviation website: http://www.dca.gov.bt/ 


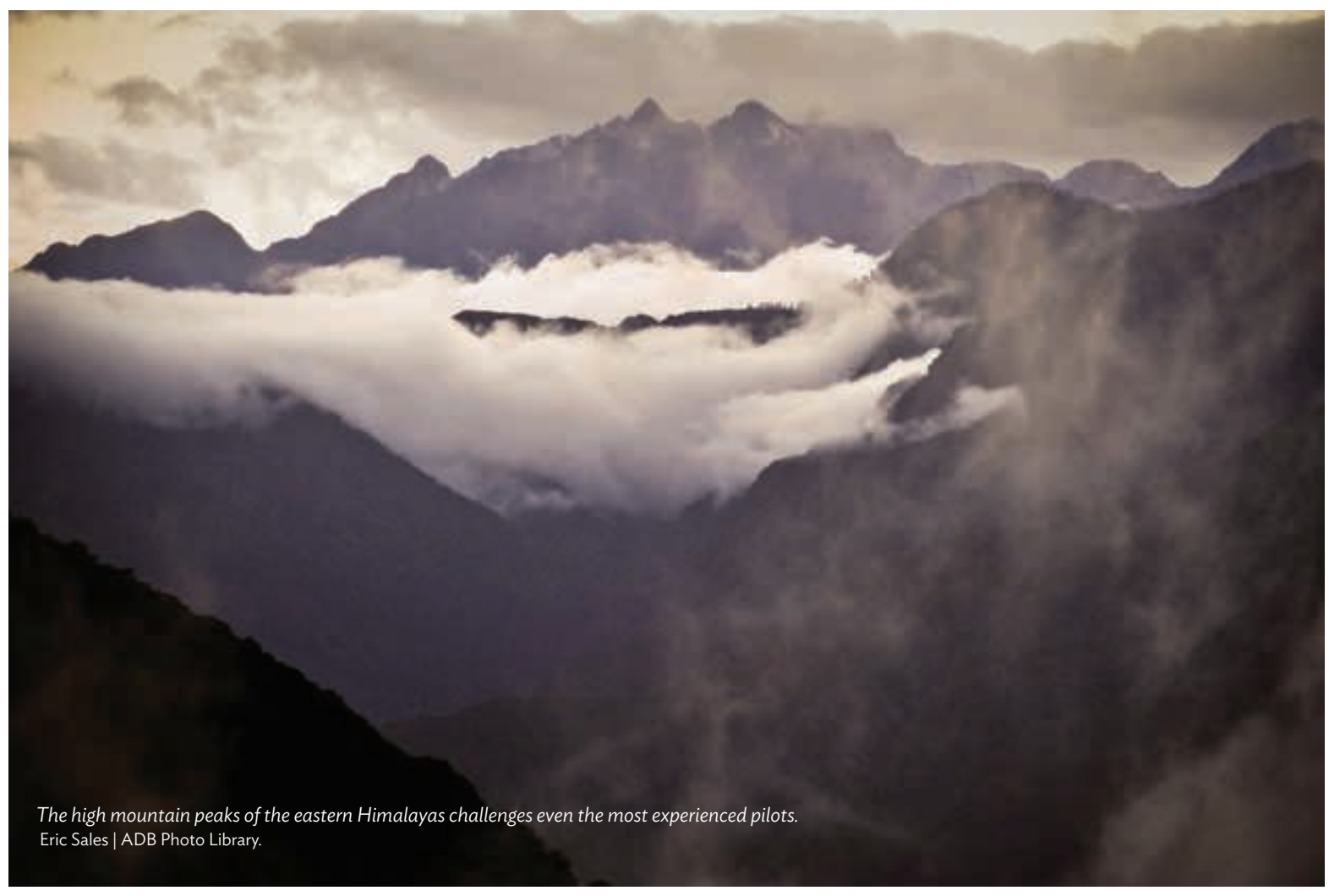

implementing an ADB project. Its aim is to improve domestic airport infrastructure to enhance safety, capacity, and efficiency of air travel within the country.

The project is to be completed by December 2017.

\section{SOLUTIONS}

Alongside initiatives to improve aviation policies and institutions, ADB's Air Transport Connectivity Enhancement Project focused on upgrading Bhutan's three domestic airports to jumpstart the air transport industry and maintain the country's air safety record.

Updated policy. A pre-project assessment ${ }^{3}$ of Bhutan's air transport sector revealed that the country needed to address legislative and institutional gaps to ensure the sector's development. Bhutan's Civil Aviation Act of 2000, which serves as the enabling legislation for the regulation and administration of civil aviation in Bhutan, was outdated in terms of conformity to international aviation laws and standards. The assessment also found significant inconsistencies between the law and the Bhutan Air Navigation Regulations, which are intended to interpret and implement the law. The assessment also noted that the Department of Civil Aviation has been responsible for both air transport operation and regulations, which creates the potential for conflict of interest that may compromise flight safety.

3 The Bhutan air transport sector assessment was part of an ADB project preparatory technical assistance. http://www.adb.org/sites/ default/files/linked-documents/44239-013-bhu-ssa.pdf 


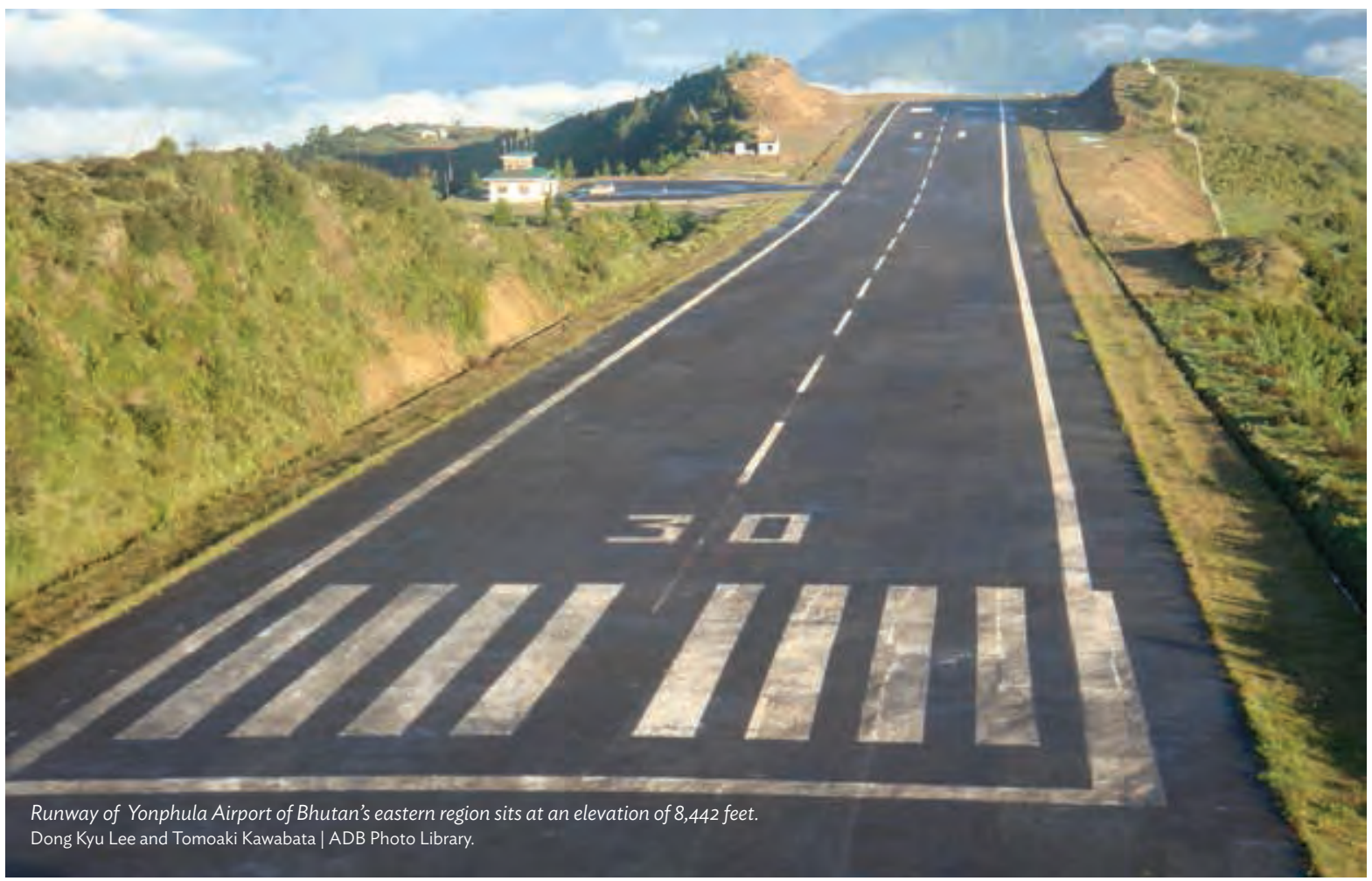

The Government of Bhutan sought ADB's assistance to address these legislative and institutional gaps. ${ }^{4}$ In 2011, a year before the project implementation, the ADB project team met with officials of Bhutan's Ministry of Information and Communication, the Department of Civil Aviation, and the Department of Public Accounts of the Ministry of Finance to discuss specific measures to strengthen the air transport sector. An organizational plan prepared by the Department of Civil Aviation illustrated the separation of regulatory and operational functions, but both would remain within the same organization and under the same overall leadership. International best practice recommends complete autonomy for a regulatory body. After thorough deliberations, the group agreed on the following actions: update the obsolete aviation law to reflect international standards, provide a policy framework for establishing a separate regulatory body, and conduct technical training to improve capacity for air transport operation and regulations.

Improved institutional capacity. The Department of Civil Aviation, as implementing agency, did not have experience with ADB-financed projects. It has experience in undertaking projects funded through government sources, and successfully implemented improvements funded by other bilateral development partners. The Department was also substantively understaffed in several areas, particularly in regulation and inspection, and lacked the capacity to provide total and effective regulatory oversight of airworthiness, flight operation, and aerodromes regulations because of staff shortages, lack of qualified staff in several of the required areas of inspection, and inadequate training and skills upgrading. In preparing for project implementation, the department staff was oriented about ADB processes. The department staff also underwent technical training to upgrade their skills and update them on the latest aviation technologies.

4 ADB. 2011. Technical Assistance to the Kingdom of Bhutan for: Strengthening Air Transport Regulatory and Operational Performance. Manila. http://www.adb.org/sites/default/files/project-document/60250/42238-012-bhu-tar.pdf 
Upgraded airports. Bhutan has three domestic airports: the Yonphula Airport in the east, the Bumthang Airport in central Bhutan, and the Gelephu Airport in the south. While the Government of Bhutan has made initial improvements in all three domestic airports, improving the physical infrastructure and acquiring the latest aviation technology are crucial for the airports to continue providing safe air transport services to an increasing passenger market. Moreover, with more airports in operation, the risk factor in aviation also increases. Aircraft take-off or landing in Bhutan requires total visibility because of the rugged terrain, unlike many airports where aircraft rely highly on communication and navigation technology. Yonphula and Bumthang began operating in 2012, offering limited in-country flights with very basic facilities, while commercial flights at Gelephu were available by 2015 .

The domestic airports were upgraded, following international engineering design standards and materials. In Bumthang, the upgrades involved the construction of a 4-kilometer-long perimeter fence, asphalt overlaying of the runway covering 36,000 square meters, and the provision of an all-weather, one-kilometer access road. In Gelephu, the upgrades were a 4-kilometer perimeter fence, security gate with guard house, apron and taxiway of 6,000 square meters, and a 2-kilometer all-weather access road. The terminal area was also expanded by 1,000 square meters. Air rescue and firefighting service support facilities, runway drainage system, flood protection structures, and communication and navigation aids equipment were also provided. In Yonphula, small hills on the sides of the runway that pose risks to landing and takeoff were flattened, and the runway strip drainage was repaired. Air rescue and firefighting service support facilities were also provided. All three airports were assigned a general service and maintenance vehicle.

Site condition surveys and field investigations aided the project team in planning the construction work. Consultations with the government's hydro-meteorological services division about civil engineering measures to enhance resilience to climatic hazards and disasters, such as flood protection and storm frequency and runoff, proved to be valuable.

The location of the airports provided challenges for implementation. Like Paro, the Bumthang and Gelephu airports are in deep valleys, while the Yonphula's runway sits across high mountaintops at an elevation of 8,442 feet. Roads to Yonphula, as in many upland areas, are mostly narrow and winding that transporting people and materials was difficult. Travel to and from the project locations was challenging for everyone directly involved in the project.

Additional financing. In 2016, the Government of Bhutan requested an additional financing of $\$ 4$ million ${ }^{5}$ to address minor but important deficiencies in security and service level at the domestic airports. The funds have provided for the construction of a passenger terminal building in Bumthang and a new aviation security staff headquarters within the airport boundary in Gelephu. It has also helped install a low safety barrier around the apron perimeter at Yonphula Airport for added passenger safety.

\section{RESULTS}

Through ADB's Air Transport Connectivity Enhancement Project, Bhutan's domestic air transport system has become fully operational, offering more flights for more passengers and linking the

5 ADB. 2016. Report and Recommendation of the President to the Board of Directors: Proposed Additional Financing to the Kingdom of Bhutan for the: Air Transport Connectivity Enhancement Project. Manila. https://www.adb.org/projects/44239-014/main 
country's disconnected regions. The project directly benefits citizens and tourists, substantially contributes to economic growth, and improves the country's measure of Gross National Happiness.

More flights. Bhutan's airspace is busier than ever. Drukair, the official flag carrier of the Government of Bhutan, has started offering commercial flights to Yonphula and Bumthang in 2012, and launched its first commercial flight to Gelephu in $2015 .{ }^{6}$ Drukair is one of two airlines providing international flights to Paro. The other is the private-owned Bhutan Airlines, which launched its commercial flights from Paro to Bangkok and Kolkata in 2013.7 Both Drukair and Bhutan Airlines have recently added new commercial aircrafts to their fleet.

Internationally, Drukair and Bhutan Airlines offer flights to Dhaka in Bangladesh, Kathmandu in Nepal, and to nearby cities in India, including Bagdogra, Kolkata, Delhi, Gaya, and Guwahati. More recently, they have open new routes to Bangkok, Mumbai, and Singapore.

More passengers. In 2010, the air passenger volume at Paro International reached 127,181 passengers annually, tripling from about 33,890 in 2000. With the continued marketing of Bhutan as a tourist destination, the upgraded airports are expected to accommodate a projected influx of international tourists. In 2013, Drukair carried 208,125 passengers, an increase of $7.6 \%$ from the previous year. ${ }^{8}$

Based on the updated air traffic forecast, if unconstrained by capacity, total air passenger traffic could grow to about 491,200 passengers annually by 2020 , of which approximately $12 \%(59,900$ passengers) would be carried on the new domestic services. By 2030, the projection reaches 915,100 passengers annually, of which domestic passengers would account for $17.4 \%$ (159,600 passengers). ${ }^{9}$ A new route from Mumbai, India allows for more tourist activity, especially since Indian nationals are not required a visa to enter Bhutan.

Enhanced connectivity. The project opens the country's isolated regions to more opportunities for trade, employment, and recreation and increases the mobility of people, goods, and services. High-value agricultural products from eastern Bhutan can reach Thimpu in less than an hour. Public services are now more accessible, especially to the poor in upland communities.

The project also links Bhutan to the global community and is in line with the government's effort to boost the tourism industry. The Tourism Council of Bhutan actively promotes the country as a prime travel destination and anticipates a busier airspace in the coming decades. Interest in Bhutan as a travel destination has been increasing in the past years, due to the government's diligent marketing of Bhutan's pristine environment, cultural traditions, and rustic way of life.

\section{LESSONS}

ADB's Air Transport Connectivity Enhancement Project offers important lessons for implementing development projects in Bhutan as well as for similar air transport connectivity projects.

6 Drukair's website: https://www.drukair.com.bt

Bhutan Airlines' website: http://www.bhutanairlines.bt

Drukair. 2013. Annual Report 2013: https://www.drukair.com.bt/COMMON.aspx?Type=press\%2orelease.htm?v1

ADB. 2011. Technical Assistance to the Kingdom of Bhutan for Strengthening Air Transport Regulatory and Operational Performance. http:// www.adb.org/sites/default/files/project-document/60250/42238-012-bhu-tar.pdf 
Update outdated policy. With ADB's assistance, the Government of Bhutan set out to update its aviation law and has enacted the new Civil Aviation Act of 2015. ${ }^{10}$ One of the major provisions of this new law is the establishment of an autonomous Bhutan Civil Aviation Authority that will oversee the regulation of aviation in the country. The new law and institutional arrangement will help ensure that air travel in Bhutan remains safe.

Ensure capacity of implementing agency. First-time implementing agencies of an ADB-financed project need guidance on how ADB conducts development work with client countries. In preparing for project implementation, the staff of the Department of Civil Aviation was oriented on relevant ADB businesses processes and procedures.

\section{Keywords:}

air transport, civil aviation, air travel safety, Gross National Happiness, Air Transport Connectivity Enhancement Project, Bhutan

\section{For further reading:}

- Project web page: http://www.adb.org/projects/44239-013/main

- Additional financing: https://www.adb.org/projects/44239-014/main\#project-pds

\section{For further information:}

- Tomoaki Kawabata, Transport Specialist, South Asia Department | tkawabata@adb.org

- Dong Kyu Lee, Unit Head for Project Administration, South Asia Department | dklee@adb.org

- Tyrrell Duncan, Technical Advisor (Transport), Sustainable Development and Climate Change Department|tduncaan@adb.org

- Ki-Joon Kim, Principal Transport Specialist, Sustainable Development and Climate Change Department | kjkim@adb.org

- Dongxiang Li, Lead Regional Cooperation and Integration Specialist, Economic Research and Regional Cooperation Department | dongxiangli@adb.org

10 See Bhutan's Civil Aviation Act of 2015: http://www.nab.gov.bt/assets/uploads/docs/bills/2015/Civil_AViation_Bill_English.pdf 


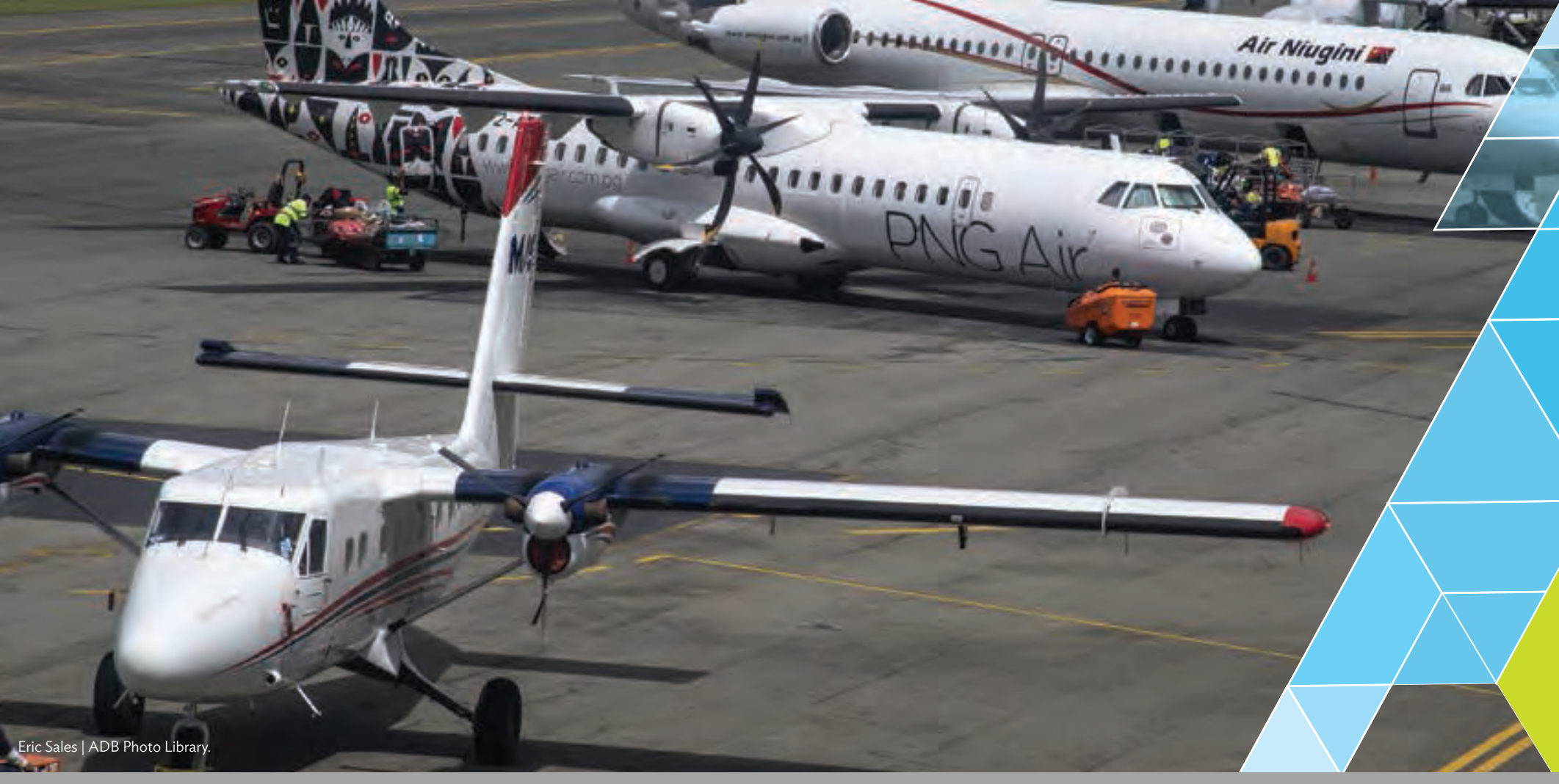

ChANgE IS IN THE AIR:

\section{MULTITRANCHE FinANCING FOR IMPROVING AVIATION in Papua New GUinea}

- Improving Papua New Guinea's air transport sector is crucial to the country's economic and social development, and the key to improving connectivity in the country.

ADB's Civil Aviation Development Investment Program, funded through its multitranche financing facility, is establishing a sustainable civil aviation network for Papua New Guinea through airport facilities rehabilitation, airport services upgrades, and institutional strengthening and capacity development of civil aviation agencies.

- The project has strengthened the roles of civil aviation agencies in supporting the overall socioeconomic development by providing safe, efficient, reliable, sustainable, and affordable aviation services and infrastructure. It has also provided all-weather access to the country, which increases the mobility of communities, and has served important community needs by making noncommercial destinations more accessible.

- The project offers lessons to similar sector development projects financed through ADB's multitranche financing facility, particularly related to keeping a skilled workforce and decentralizing institutional functions to support longterm maintenance. 


\section{CONTEXT}

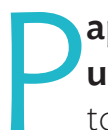
apua New Guinea's air transport system requires serious upgrades. The country's airports are deteriorated, posing threats to air safety. Air navigation systems are outdated and unreliable. Flight cancellations are frequent, operations are restricted, and the cost of airline operations are high. Many airlines are losing business; their eventual closure would disable international trade and restrict domestic mobility and tourism. Improving Papua New Guinea's air transport sector is crucial to the country's economic and social development.

Papua New Guinea's rugged terrain and extreme climate make road construction difficult, which is why the country has no safe and extensive road network. Being an archipelago, the country relies highly on aviation as a major transport mode. A sizeable port sector consists of 22 declared ports and numerous wharves, jetties, and landings.'

Papua New Guinea has more than 450 aviation facilities, which consists of 22 national airports, mostly located in provincial capitals, and hundreds of rural airstrips. The Jacksons International Airport, in the capital Port Moresby, serves as the main gateway into the country. Four major airlines-Air Niugini, PNG Air, Qantas, and Philippine Airlinesplus more than 20 other operators offer international and domestic flight services. Passenger traffic has recently grown by about 10\% yearly on average, aircraft movements by $5 \%$, and freight demand by about $4 \%$. These rates are well below the growth in GDP, which has averaged 6.4\% in recent years. ${ }^{2}$

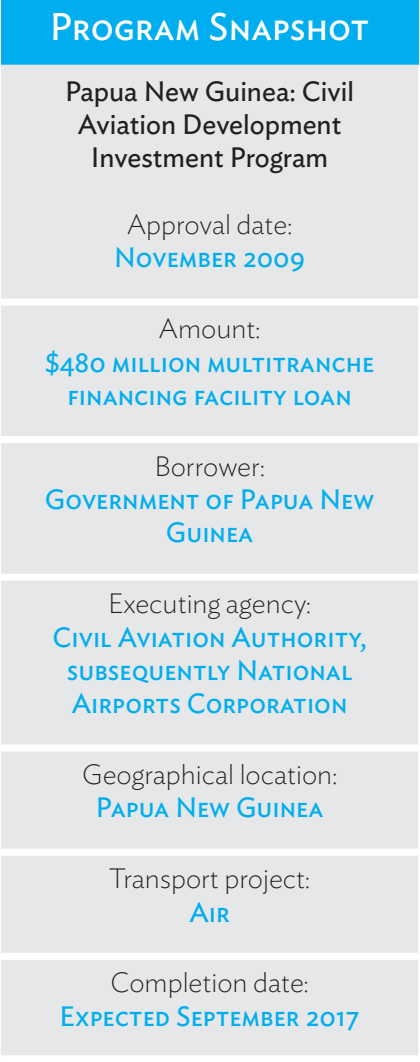

Two key institutions administered, regulated, and managed the civil aviation sector. The Department of Transport was the lead agency for transport strategy and planning, while the Civil Aviation Authority was responsible for airports, air traffic management, and regulatory oversight. Strengthening the capacity of these institutions has been a major government priority.

In 2009, ADB approved the Civil Aviation Development Investment Program to help Papua New Guinea upgrade its national airports and to strengthen civil aviation safety and services. The program supports the realization of the Government's long-term vision for the civil aviation sector by providing a flexible financing framework for sector development, including sustaining a long-term partnership needed to build institutional capacity. Funding is provided through ADB's multitranche financing facility, ${ }^{3}$ a financial instrument that establishes a partnership framework between ADB and a client government for large and long-term sector financing.

The project is expected to be completed by September 2017.

1 Case study on the Papua New Guinea: Lae Port Development Project (page 9)

2 ADB. 2009. Report and Recommendation of the President to the Board of Directors: Proposed Multitranche Financing Facility to Papua New Guinea for the Civil Aviation Development Investment Program. Manila.

3 ADB. 2008. Mainstreaming the Multitranche Financing Facility. Manila. https://www.adb.org/documents/mainstreamingmultitranche-financing-facility 


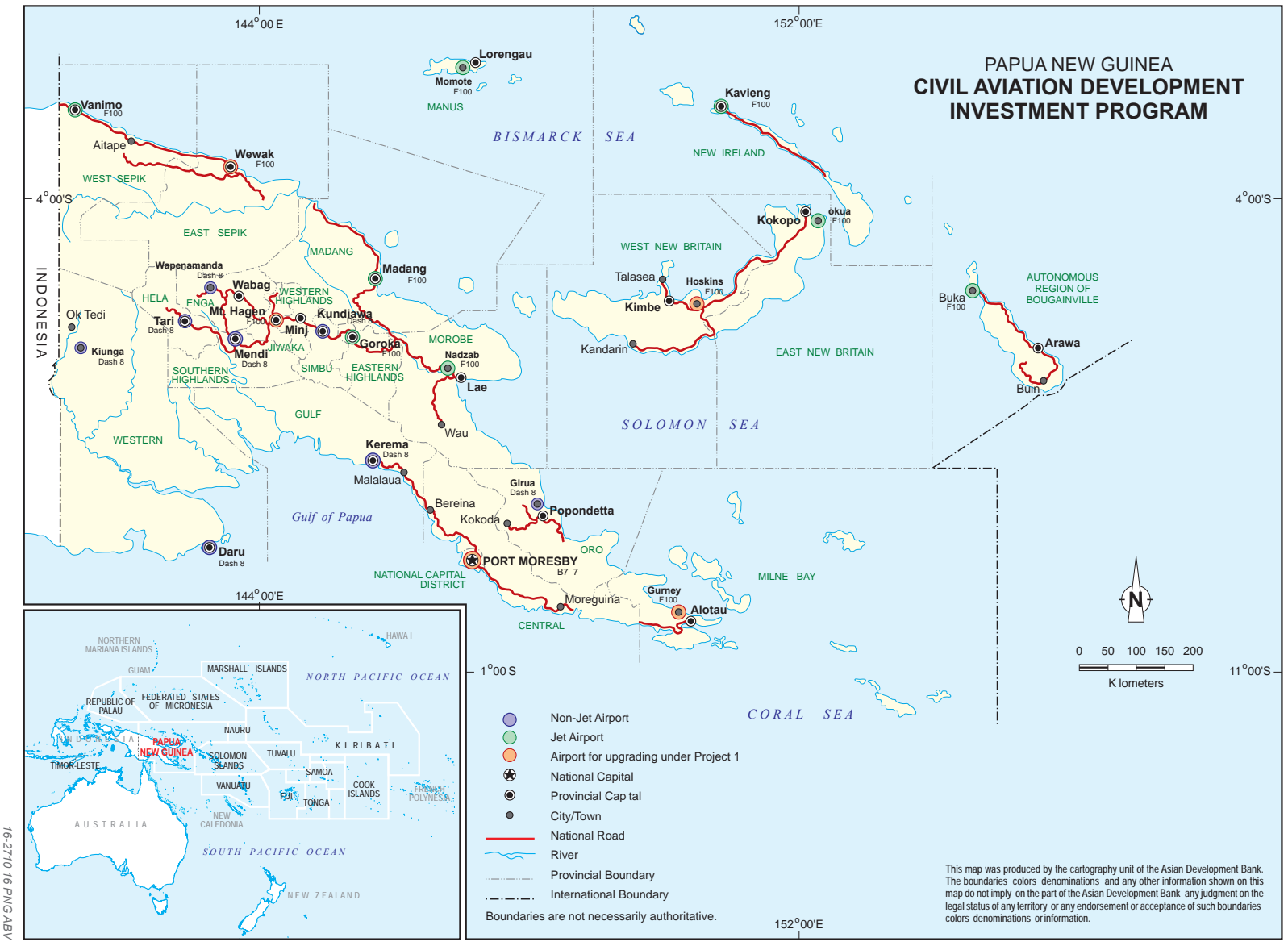

\section{SOLUTIONS}

ADB's Civil Aviation Development Investment Program involves long-term investments, covering a span of 10-20 years. It aims to support the government's targets in strengthening the civil aviation industries. Sustainable investment plays a critical role in not only tackling capacity constraints and deteriorating infrastructure, but also in long-term maintenance. Dilapidated and unmaintained infrastructure threaten the safety certification of airports and place these socioeconomic objectives at risk. ${ }^{4}$

Use of multitranche financing facility. The government and ADB agreed that ADB's MFF was the most suitable mode of financing because it supports medium- to long-term investment programs, usually derived from a country's sector roadmap. The MFF offers ADB's client countries a fixed credit line for project loans, with reduced commitment fees and flexible long-term management set-up, which is suitable for large-scale sector development such as air transport in Papua New Guinea. To avail of the MFF, ADB requires client countries to have an existing policy framework and a sector roadmap, with a clear investment and financing plan. Financing comes in the form of loans and guarantees that are spread over time in tranches, which are committed only when programmed investments become ready for financing. Fees are applied only on committed amounts and not on the total value available under the MFF.

4 Civil Aviation Authority. 2008. Strategic Investment Plan. Port Moresby. 
Papua New Guinea's National Transport Development Plan 2011-2020 provides the overall policy framework, with the key objective of reforming the Civil Aviation Authority to become self-sufficient and fund the maintenance of airports and airways. The Civil Aviation Authority's Infrastructure Investment Plan-Long-Term 2010-2030 offers a well-thought-out sector development roadmap.

ADB and Papua New Guinea entered into a Framework Financing Agreement to guide project development under the investment program and prepared a Facility Administration Memorandum to guide project or tranche implementation. ADB has provided a credit line of up to $\$ 480$ million to help fund the investment program. The Government of Papua New Guinea has allocated $\$ 85$ million. Financing is provided in slices or tranches, based on the government's submission of the related periodic financing requests, execution of the related loan agreements, and fulfillment of the terms and conditions and understandings set forth in the Framework Financing Agreement. These tranches, consecutive but overlapping, have financed specific projects or sets of projects under the investment program.

Under the MFF, ADB and the government have implemented projects with clearly defined objectives, definitive financing requirements, and realistic implementation timetables. Initially, the investment program focused on priority actions to comply with international security and safety standards, and then on increasing capacity for growth in services.

The first project, ${ }^{5}$ amounting to $\$ 112$ million of which ADB funded \$95 million, involved physical improvements in several national airports to comply with international safety and security standards and supported the restructuring of the Civil Aviation Authority. The second project, ${ }^{6}$ with a tranche amount of $\$ 130$ million, with a total amount of $\$ 170$ million, further improved airport infrastructure, upgraded air navigation services, and enhanced operations of the civil aviation agencies that evolved from the restructuring of the Civil Aviation Authority. Activities under the first project were completed in 2015, while activities under the second project are nearing completion at the time of writing. The third tranche of $\$ 248$ million is targeting improvements and long-term maintenance, and includes airport asset management, further upgrades, and capacity development. The first project has been completed in 2015, the second is nearing completion, and preparations for the third are ongoing.

Decentralization and institutional restructuring. The first project under the investment program financed the restructuring of the Civil Aviation Authority in 2010, aimed at decentralizing aviation functions. The project has resulted in the establishment of three autonomous state-owned enterprises. The National Airports Corporation is tasked to manage the country's national airports. The Papua New Guinea Air Services Limited is to provide air traffic management and navigation services. The Civil Aviation Safety Authority is to serve as regulatory body for civil aviation. The first project also supported the new National Airports Corporation in engineering design, preparation of bid documents and procurement, and preparation of investment proposals for subsequent projects and tranches for ADB approval.

The second project focused on strengthening and sustaining the operation of the three new aviation institutions. In 2015, the Papua New Guinea Accident Investigation Commission was also

5 Papua New Guinea: Civil Aviation Development Investment Program-Project 1 (project page). http://www.adb.org/ projects/43141-023/main

6 Papua New Guinea: Civil Aviation Development Investment Program-Tranche 2 (project page). http://www.adb.org/ projects/43141-043/main 
established. The National Airports Corporation, which has gained experience in implementing the first project under the investment program, superseded the Civil Aviation Authority as executing agency. The corporation has completed technical designs of civil works, including pavement rehabilitation, and security fencing. It has also led the preparations of projects for the third and final tranche and has been functioning efficiently in administering the activities under this.

Airport infrastructure and technology upgrades. The physical and technological improvements of Papua New Guinea's airports require rehabilitating airport infrastructure, including runways, taxiways, and aprons; improving runways and passenger terminals that can accommodate larger aircraft; and upgrading communication, lighting for night operation, navigation, surveillance, and firefighting equipment.

The first project prioritized improving pavements and fencing in Wewak, Hoskins, Gurney, Mount Hagen, and Jacksons airports to comply with international safety and security standards. Together, these airports serve about 1.5 million people.7 New security fences in Kavieng and Goroka airports were also installed. Equipment for communication navigation and surveillance were modernized to meet air traffic management requirements. Fire safety and rescue equipment were procured to meet operational requirements.

The second project focused on establishing the civil aviation network, and improving connectivity among the airports through communication and navigation technology upgrades. Facilities and infrastructure in Goroka, Girua, Chimbu, Vanimo, Momote, and Buka airports have been upgraded and/or rehabilitated. Firetrucks and navigation systems were procured. In addition, capacity development and strengthening activities for the new aviation agencies were conducted.

Long-term maintenance. Financing is also required of recurrent maintenance costs to avoid the costly cycle of deterioration and rehabilitation, and ensure continuous safety and security certification. To ensure proper and sustained funding, the project maximized the recovery of operating costs, while tariff reviews took into account operation and maintenance requirements. Passenger terminal fees at the national airports were adjusted to match the need for terminal and infrastructure maintenance.

Long-term maintenance contracts are an integral component of the investment program. For the 22

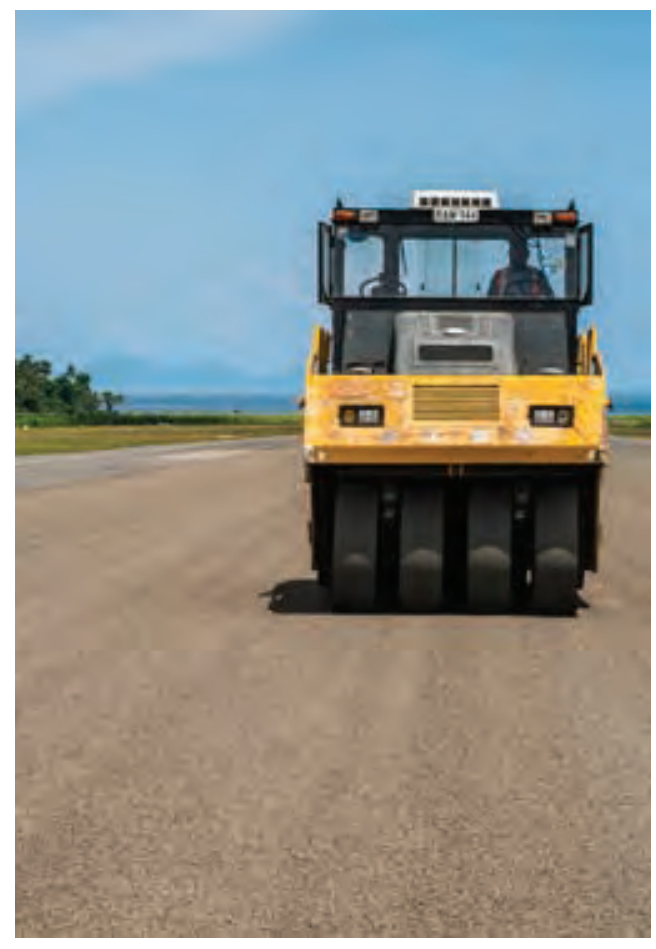

Runway improvement. ADB Photo Library.

7 Apart from being Papua New Guinea's gateway for international flights, Jacksons International Airport also serves as a hub for all national airports. The Mount Hagen airport is the major airport in the Highlands region, providing access to four major provinces: Chimbu, Enga, Southern Highlands, and Western Highlands provinces, which are the country's major coffee-growing and mineral resource-based economies. The Hoskins airport is the major airport for West New Britain and serves a major island economy that specializes in oil palm production. Wewak, the provincial capital of East Sepik, is a major coastal economy on the northern side of the mainland specializing in timber and natural resources. The Gurney airport provides connections with Alotau, the provincial capital of Milne Bay province, and access to tourist destinations along the country's lower-eastern coastline. 


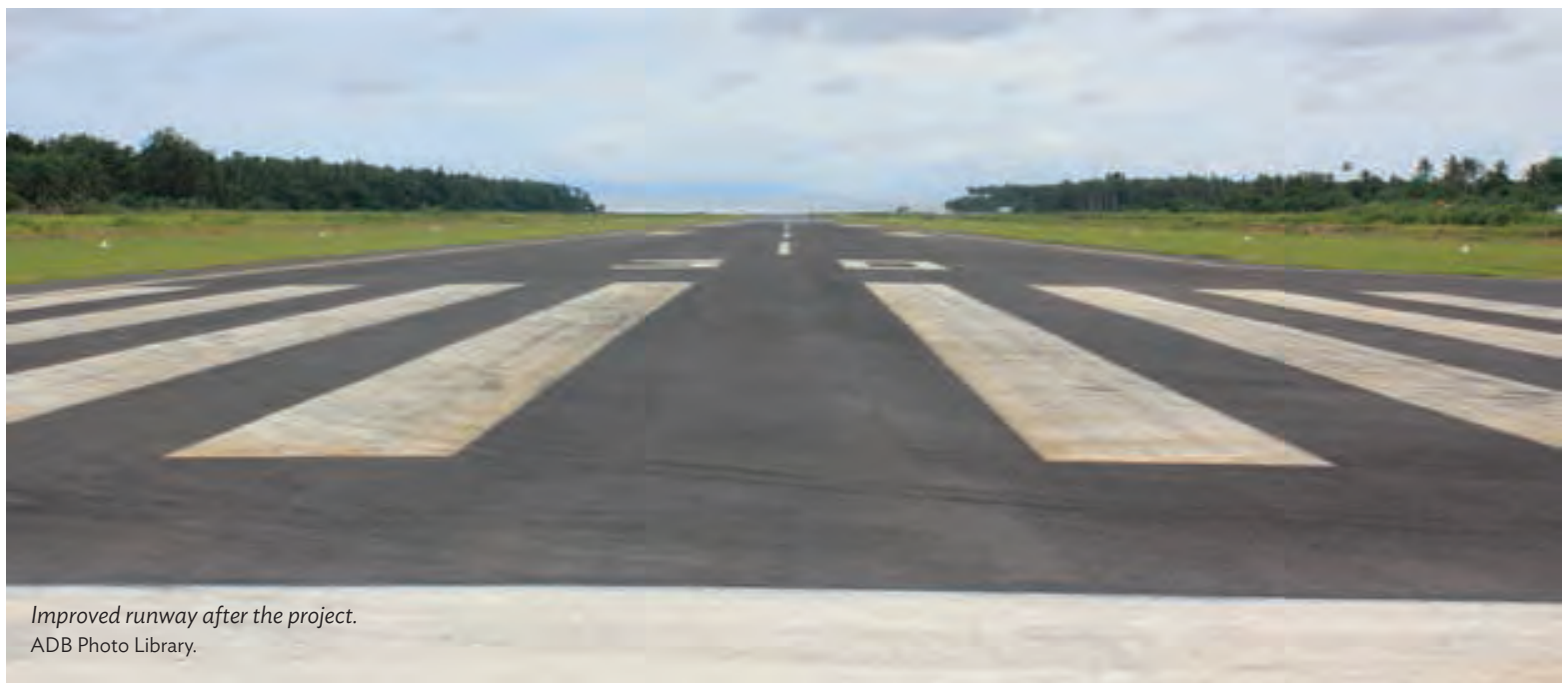

national airports covered by the program, facilities were upgraded and maintenance was improved to a specified standard under civil works contracts for a contract period of 10 years. The contracts are performance-based, with fixed monthly payments contingent on meeting the performance standards and defined penalties for underperformance. These contracts may be "unit rate" contracts to start with and convertible after 2 years into "performance-based" contracts.

A related issue in long-term maintenance was retaining a qualified workforce. Many of the staff who have been trained left the project for better offers; the project management team had to recruit and train new staff. Also, Papua New Guinea has been struggling to cope with skilled and semiskilled labor demands, and the project had to make do with the country's limited workforce.

\section{RESULTS}

When completed, ADB's Civil Aviation Development Investment Program will bring safer, more secure, and more efficient all-weather access to air transport services across Papua New Guinea. Thus far, the newly established aviation institutions are collectively working to improve the sector.

Improved civil aviation institutions and services. The restructuring of the former Civil Aviation Authority has been completed, and the newly established aviation institutions are fully operational. The National Airports Corporation now owns and operates the country's 22 national airports. The Papua New Guinea Air Services Limited provides navigation services, including communication, navigation, surveillance, and air traffic management system to domestic and international airline operators that use the country's airspace. The Civil Aviation Safety Authority of Papua New Guinea regulates civil aviation, including enforcement of industry rules, monitoring of safety and security, as well as adherence to international aviation standards. A new Papua New Guinea Accident Investigation Commission was established in 2015. The staff of these aviation institutions has undergone relevant training.

A more experienced National Airports Corporation with a stronger workforce now serves as executing agency for the investment program. The corporation has completed technical designs of civil works, including pavement rehabilitation and associated works, and security fencing and associated works. 
Better airports and air transport connectivity. For the first project, pavements and security fencing in the five priority airports-Wewak, Hoskins, Gurney, Mount Hagen, and Jacksons - were improved and now in compliance with international safety standards. New security fences in Kavieng and Goroka airports were installed. Hoskins Airport now has a new terminal building and the runway was extended and paved. A new terminal building for both domestic and international flights was also constructed for Mount Hagen Airport. At Jacksons International Airport, a new instrument landing system and domestic apron extension were installed, and firefighting vehicles were procured.

The first project also saw the official opening of the upgraded Hoskins Airport in West New Britain, Western Province. Hoskins is expected to boost connectivity between West New Britain and the rest of the country and stimulate the local economy. The improvements included an extension of the runway to 1,900 meters, strengthened pavements, installation of a perimeter security fence, a modernized terminal building with an ecofriendly sewerage system, and new solar-powered street lights around the terminal to boost energy efficiency.

For the second project, new security fencing was installed at Momote and Buka airports. Pavement strengthening and upgrading were provided for Goroka, Girua, Chimbu, and Vanimo airports. Goroka airport now also enjoys a new terminal building. The airports' aeronautical and navigation equipment were also modernized. Procurement included a radio aeronautical communication system, a secondary surveillance radar system, airport rescue, and firefighting vehicles.

\section{LESSONS}

ADB's Civil Aviation Development Investment Program offers lessons in administering large-scale sector development projects financed through ADB's MFF.

Develop incentive programs to retain a skilled workforce. A resource gap in experienced and qualified staff in the Civil Aviation Authority was holding back the development of Papua New Guinea's air transport sector. The project implementation unit has also had a difficult time keeping trained people employed. Incentive programs to retain a skilled workforce are necessary for longterm maintenance of air transport facilities and services. Capacity building, not only for the project implementation unit but also for the staff of the different aviation agencies, is also needed.

Decentralize functions and provide continuous institutional support. Developing a country's aviation sector requires a huge amount of financing. Developing efficient and effective institutional structures and providing long-term support and capacity development in implementing the sector road map is crucial in projects financed through the MFF. To eliminate the risks of conflicts of interest, operating and regulatory functions should be housed in separate institutions. Updated and rationalized fees linked to the demand created by expanded aviation services will also be realized. Continuous support for institutional development and for monitoring and evaluation through the investment program should be delivered through government systems. 


\section{Keywords:}

air transport, civil aviation, multitranche financing facility, Civil Aviation Development Investment Program, Papua New Guinea

\section{For further reading:}

- Project web page: http://www.adb.org/projects/43141-013/main

- Papua New Guinea: Civil Aviation Development Investment Program—Project 1: http://www. adb.org/projects/43141-023/main

- Papua New Guinea: Civil Aviation Development Investment Program-Tranche 2: http://www. adb.org/projects/43141-043/main

\section{For further information:}

- Muhammad Amir Ingratubun, Principal Infrastructure Specialist, Pacific Department | mingratubun@adb.org

- Tyrrell Duncan, Technical Advisor (Transport), Sustainable Development and Climate Change Department |tduncan@adb.org

- Ki-Joon Kim, Principal Transport Specialist, Sustainable Development and Climate Change Department|kjkim@adb.org

- Dongxiang Li, Lead Regional Cooperation and Integration Specialist, Economic Research and Regional Cooperation Department | dongxiangli@adb.org 


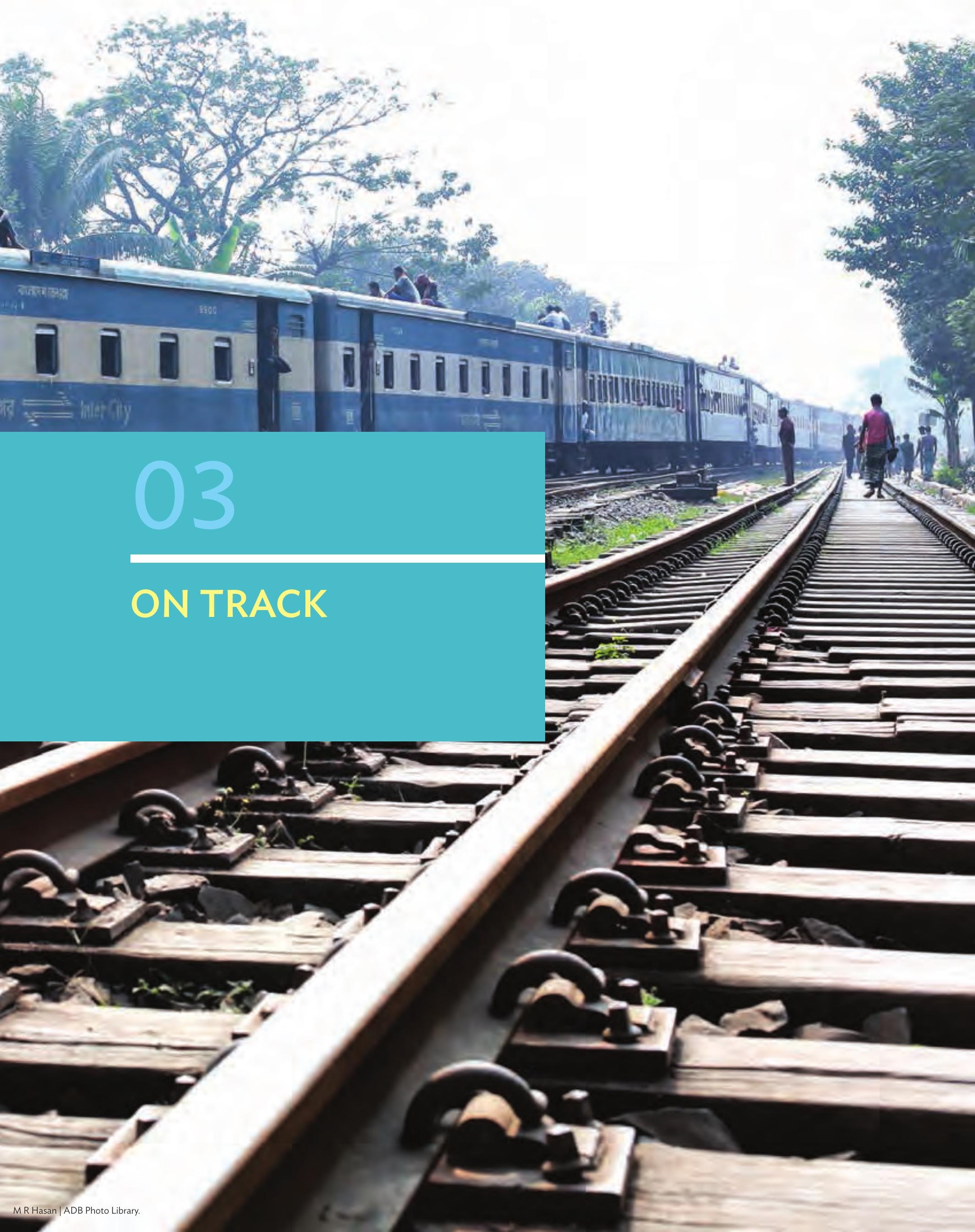




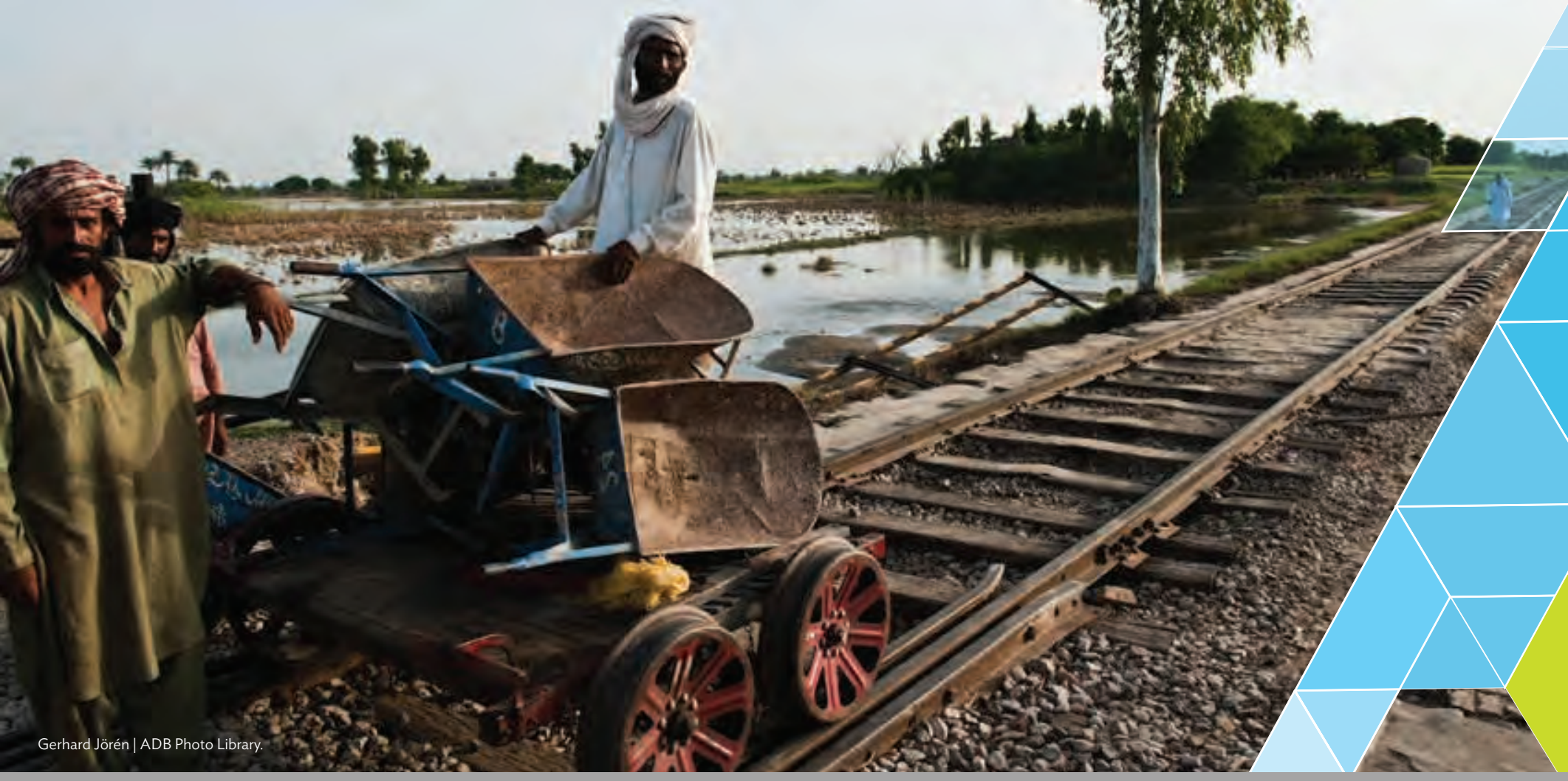

TRADE AND AID EXPRESS:

RAIL CONSTRUCTION IN A HIgH SECURITY RISK ENVIRONMENT IN AFGHANISTAN

Afghanistan needed to reestablish cross-border links to allow for the safe, efficient, and timely passage of international trade goods and all-important humanitarian relief into the war-torn and landlocked country.

ADB's Hairatan to Mazar-e-Sharif Railway Project provided a much-needed railway from Mazar-e-Sharif to Hairatan through a customized turnkey contract, heightened site security precautions, and enhanced coordination among project partners.

Construction of the railway was finished ahead of schedule, considering the challenging environment. Freight and humanitarian relief now flow in greater volumes into the country.

I In high security risk areas, enhancing security supervision and coordination and faster procurement and disbursement can aid in the safe and timely completion of the project. 


\section{CONTEXT}

\section{Ar-torn, landlocked, and isolated, Afghanistan needed to facilitate the safe, efficient, and timely passage of international humanitarian aid and trade goods.}

Afghanistan's transport network was crippled and its cross-border links with neighbors were cut off, hampering international trade and the entry of relief goods. Having achieved relative peace, the new unitary government ${ }^{1}$ prioritized the construction of a railway from the trade gateway of Hairatan to the town of Mazar-e-Sharif near the border with Uzbekistan to reestablish cross-border links.

Amid concerns for landmines and illegal armed groups, Afghanistan needed to restore important transport infrastructure to get the country's economic gears turning. Afghanistan depends mainly on its 38,500-kilometer road network, much of which are unpaved or have been damaged by war. International donor agencies have been helping to improve the road sector, including ADB, which has financed the improvement of nearly 1,100 kilometers of regional and national roads since $2004 .^{2}$ Trucks are the common choice for transporting international freight from the borders, but unloading and reloading of cargo can be slow, costly, and inefficient. ${ }^{3}$ Improving the country's underdeveloped railway ${ }^{4}$ would help increase the flow volume of transit goods.
PROJECT SNAPSHOT

Afghanistan: Hairatan to Mazar-e-Sharif Railway Project

Approval date: SEPTEMBER 2009

Amount:

\$165 MILLION GRANT

Borrower:

Government of Afghanistan

Executing agency:

Ministry of PUblic WorkS

Geographical location: HAIRATAN TO MAZAR-E-SHARIF, AFGHANISTAN

Transport project: RAIL

Completion date: DECEMBER 2012

In 2009, ADB approved the Hairatan to Mazar-e-Sharif Railway Project to help ease the traffic build up at the Hairatan border post by providing an alternative to road transport to Mazar-e-Sharif and the ring road. The project involved the construction a 75-kilometer single railway line from Hairatan to Mazar-e-Sharif and associated support infrastructure and facilities, and a railway station and transshipment facilities at Mazar-e-Sharif. It also included upgrading the marshaling yard and railway station at Hairatan, signaling and telecommunication systems, and safety facilities.

ADB conducted a preparatory study 5 and the plan was to initially construct a railway line between Hairatan and Mazar-e-Sharif as an extension of an existing line from Termez in Uzbekistan to Hairatan at the Afghanistan border. The Hairatan to Mazar-e-Sharif Railway connects to transport corridors under the CAREC ${ }^{6}$ Program, which aim to increase trade within the region.

1 Following the ouster of the previous regime, the country elected and established a unitary government. ADB. 2008. Country Partnership Strategy: Afghanistan, 2009-2013. Manila. http://www.adb.org/sites/default/files/institutional-document/32267/files/cpsafg-2009-2013.pdf

2 See related story on page 46

3 Trucks are not required special transit charges and foreign trucks transporting freight pay only a $5 \%$ commission.

4 There are two unconnected railways, both cross-border extensions-from Turkmenistan to a transshipment yard in Torghandi (10 kilometers) and from Uzbekistan to a transshipment yard in Hairatan (15 kilometers).

5 ADB. 2011. Technical Assistance Completion Report: Railway Development Study in Afghanistan. Manila. http://www.adb.org/projects/ documents/railway-development-study

6 The CAREC Program is a partnership of 10 countries (Afghanistan, Azerbaijan, the People's Republic of China, Kazakhstan, the Kyrgyz Republic, Mongolia, Pakistan, Tajikistan, Turkmenistan, and Uzbekistan), supported by six multilateral institutions. CAREC helps Central Asia and its neighbors realize their significant potential by promoting regional cooperation in four priority areas: transport, trade facilitation, energy, and trade policy. http://www.adb.org/countries/subregional-programs/carec 


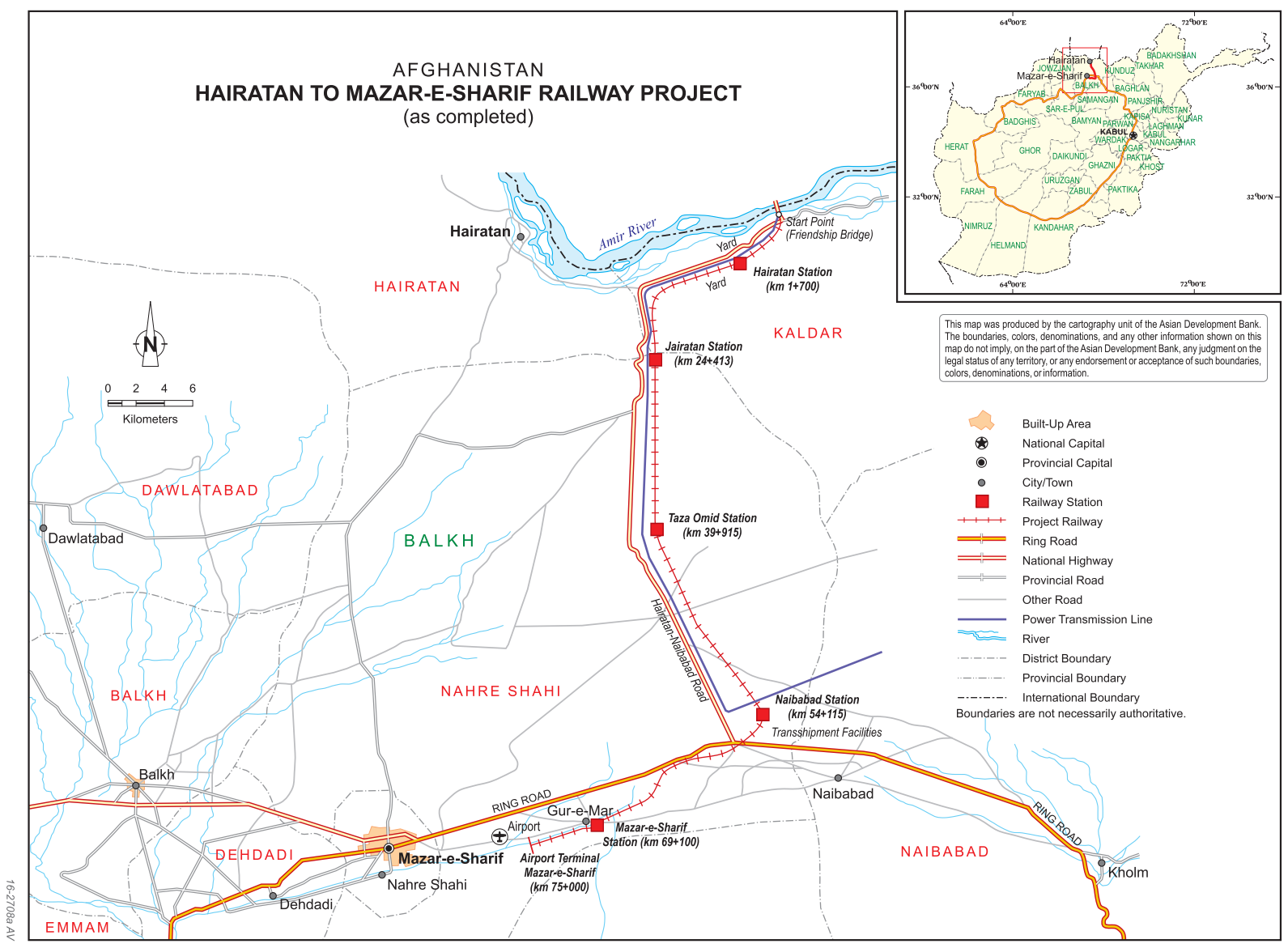

Railway construction began in January 2010 and the railway was completed in November 2010.

\section{SOLUTIONS}

ADB's Hairatan to Mazar-e-Sharif Railway Project features measures in constructing an urgently needed railway within a challenging high security risk environment.

Safe and secured construction site. ADB's Hairatan to Mazar-e-Sharif Railway Project was implemented at a time when the Government of Afghanistan was still in the process of ensuring long-lasting peace in the country. The project faced potential security disruptions during implementation. Collaboration among the governments of Afghanistan and Uzbekistan, the secretariat of the CAREC Program, and ADB paved the way for developing and carrying out the project's comprehensive implementation plan.

An executive committee tasked to make quick decisions during implementation was constituted with officials from the Ministry of Commerce and Industry, the Ministry of Finance, the Ministry of Interior Affairs, the Ministry of Mines, and the Ministry of Public Works. The Ministry of Interior Affairs coordination efforts yielded a detailed security plan to ensure that the construction was not interrupted, and that adequate protection and safety for all personnel on site were provided. The committee also provided overall guidance, facilitated approvals from various agencies, and ensured 


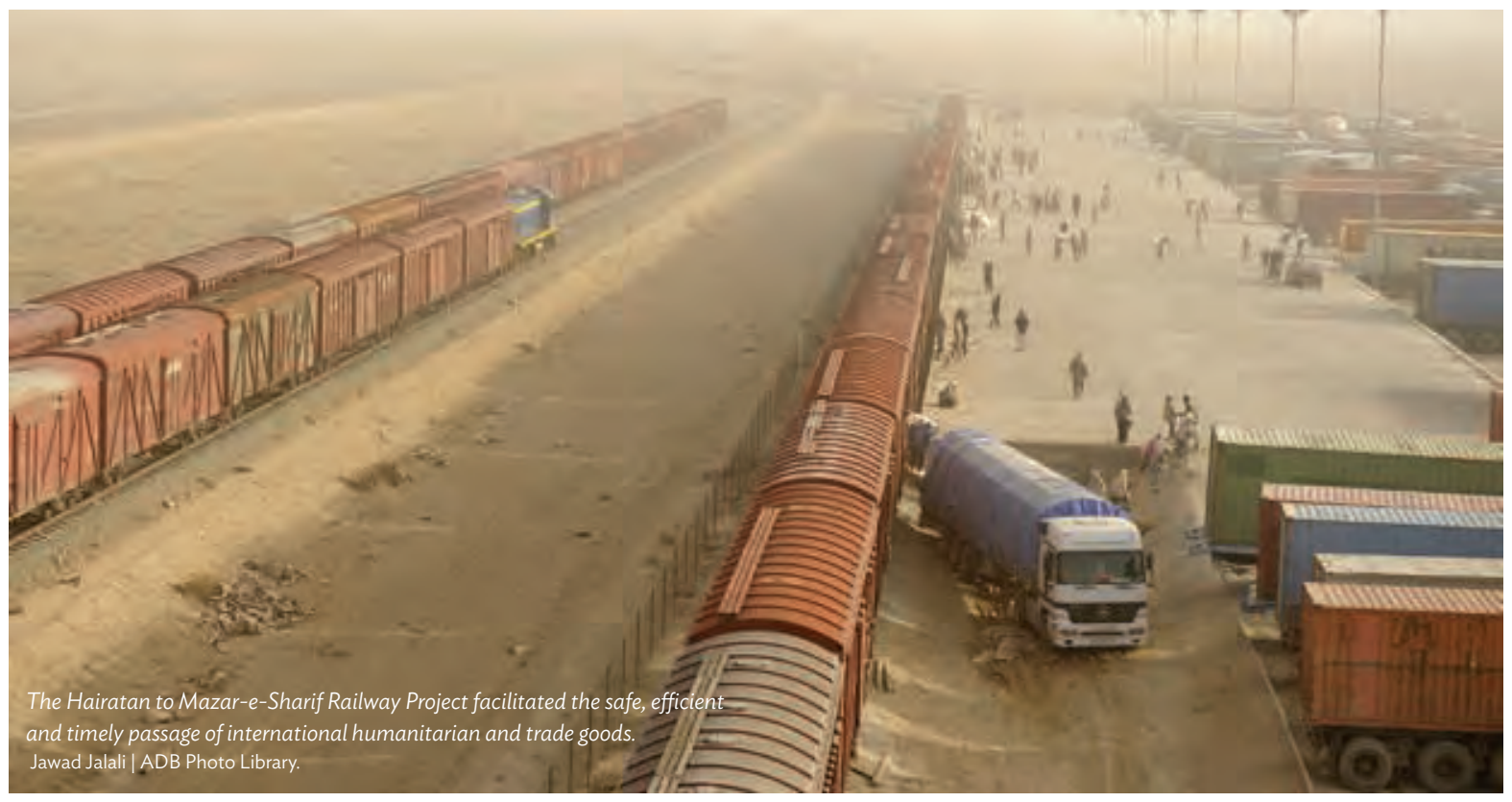

security arrangements on site, including coordination with the International Security Assistance Force. To coordinate security matters among the ministries of public works and interior affairs, the provincial government, the International Security Assistance Force, and ADB, the project availed of the services of international and national security specialists. About 463 police personnel were deployed at the project site and at about 62 check posts to provide overall security on site and ensure uninterrupted operation through 24-hour police patrolling. Fencing, check posts and watchtowers, security cameras, electronic locks on station building doors, grills on windows and doors, and other measures were installed to strengthen security along the railway line. ADB's security staff at the resident mission in Kabul provided overall supervision and guided the security personnel on the implementation of the security plan.

Turnkey contract for quick construction. Considering the urgency of Afghanistan's need for the railway, the ADB project team decided on a "turnkey" engineering, procurement, and construction contract to expedite the project's implementation. The turnkey contract allowed for contracting the construction of the railway to a contractor at a fixed price and fixed delivery period. The contract also imposed appropriate penalties for nonperformance and a bonus for timely completion.

The Uzbekistan Temir Yullari, a joint-stock government-owned company that operates the Uzbekistan rail network, was invited to bid and awarded the contract through direct selection and after independent evaluation. The company was selected mainly because the project railway line is to be an extension of the current Uzbekistan network into Afghanistan and based on the Uzbekistan track gauge system. There was also no other operator in the region with the same level of experience for designing, building, and operating a railway line based on the Uzbekistan system.

Preliminary discussions between officials of the governments of Afghanistan and Uzbekistan on extending the railway set the project in motion even before ADB's approval of the grant. The Uzbekistan Temir Yullari also had expressed its willingness to take on the railway's construction, since the company already had proprietary preliminary designs. 
Preconstruction preparations, including procurement, negotiations, and signing, were also expedited so that construction can begin at once. ADB undertook procurement activities upon the government's request for faster processing and also helped facilitate contract negotiations between the government and Uzbekistan Temir Yullari.

Early completion of construction was due to Uzbekistan Temir Yullari's comprehensive planning and management of construction, resource

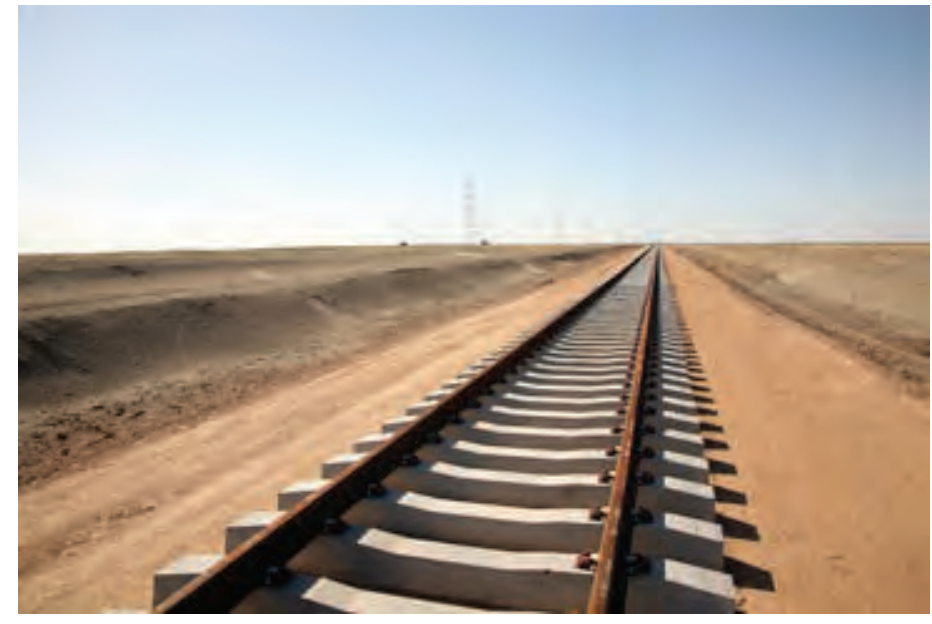

A portion of the Hairatan to Mazar-e-Sharif Railway Project. Ash Sweeting | ADB Photo Library. mobilization, and site management. However, quick construction would not have been carried out without a thorough security plan and speedy disbursement of funds by ADB. Since almost $50 \%$ of the project cost went to the advance purchase of railway materials, disbursement of funds needed to be quick, just in case the contractor ran into cash-flow problems. In lieu of cash, a letter of credit arrangement facilitated the contractor's timely purchase of materials to avoid construction delays due to late delivery of materials.

Performance-based operation and maintenance. While construction was underway, the government requested ADB for further assistance on operation and maintenance of the railway facilities and added infrastructure to help facilitate the railway's daily operation for the first year. ADB granted the request right away, reallocated funds for improving operation and maintenance, and drew up a performance-based contract, with the help of independent railway and legal experts.

The contract details operational requirements, standards, and maintenance of the railway line. Following a similar bonus and penalties scheme, the contract determined revenue targets and performance indicators that are linked to payments to the railway line operator. Within a month of processing and parallel procurement, the contract was awarded, and the employer, the consultant, and the contractor were brought together for closer coordination and implementation. Initial operation of a maximum two trains in each direction daily was planned.

New railway management. The government foresaw the need for an overarching institution that would not only oversee the rail link from Hairatan to Mazar-e-Sharif, but also develop the government's capacity for railway sector planning. The Hairatan railway station was under the management of the Hairatan Port Authority, a corporate entity under the Ministry of Commerce and Industry. Railway operation between Termez and Hairatan, including the operation of the marshaling yard, were part of an Afghanistan-Uzbekistan Railway Agreement signed in 2003.

In 2013, the government created the Afghanistan Railway Authority, which would take the lead in the planning, development, regulation, and management of the railway sector. Managing rail assets, ensuring financial sustainability, and encouraging private sector participation are also among the authority's future responsibilities, as well as formulating and implementing policies and regulations for the commercial operation of the railways in Afghanistan. The authority is currently being strengthened with the required staff and expertise. 


\section{RESULTS}

ADB's Hairatan to Mazar-e-Sharif Railway Project finished railway construction in a short span of time and, under new management, has been fully operational, allowing for the entry of vital humanitarian aid and the increase in cross-border freight and passenger transfers.

Quick, secure construction. With a turnkey contract, Uzbekistan Temir Yullari designed the railway, procured the necessary materials, and finished construction work all in 10 months, about 2 months ahead of schedule. After signing the contract, the company began its work immediately and finished construction under the planned 12-month implementation. Testing and trial operation followed, and the railway was declared ready for operation in March 2011. Constructing the Hairatan to Mazar-e-Sharif in record time in a challenging environment was an extraordinary achievement in engineering and project management in the international development community.

\section{Initial gains from the new} railway. The Hairatan to Mazar-

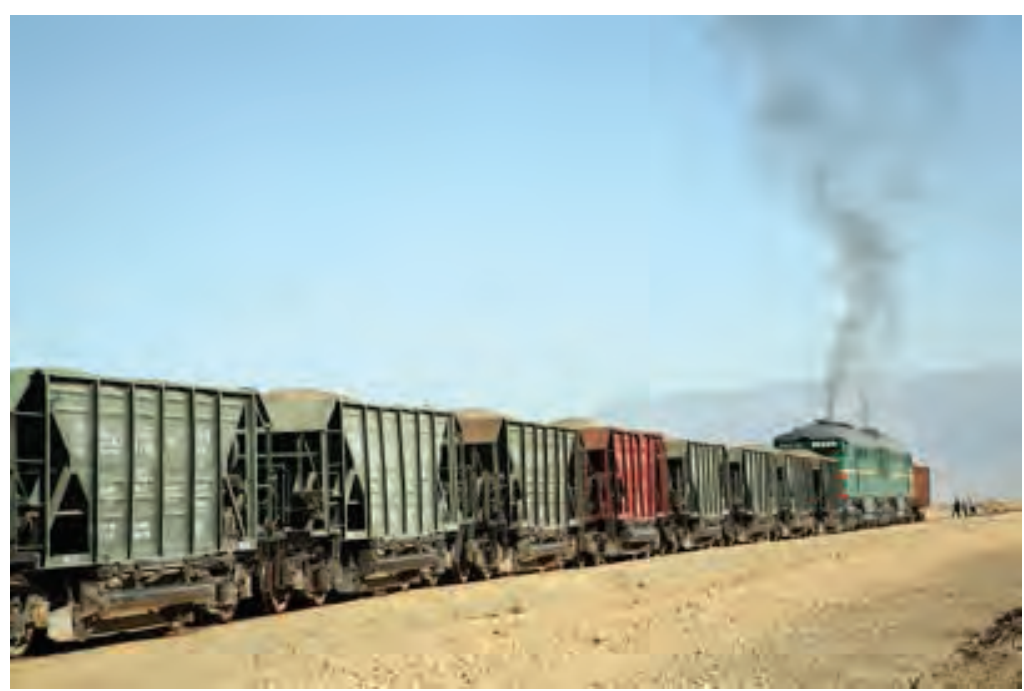

The 75-kilometers railway connects Mazar-e-Sharif town to the trade gateway of Hairatan and to the rest of Afghanistan.

Ash Sweeting | ADB Photo Library.

e-Sharif Railway hosted its inaugural commercial freight train trip on 3 February 2012. Nine railcars containing flour from Kazakhstan and three cars of timber from Siberia traveled 54 kilometers from Hairatan to the Naibabad terminal. Naibabad Station has been bustling with activity, as hundreds of workers unload newly arrived freight trains. With the new railway in operation, job opportunities in Naibabad and elsewhere along the rails have shown an overall growth of over 10\% per year since 2010. About 1,200 people are currently employed in logistics and unloading operations. Lower transport costs have reduced the price of goods. Humanitarian relief has reached hard-hit areas and various parts of the country more quickly and efficiently.

Freight transported by trains reached about 6,500 tons daily in 2012 and is projected to grow by nearly $11 \%-12 \%$ annually. The freight travel time from Hairatan to Mazar-e-Sharif had been cut from 2 hours by road to 1 hour by rail. Because of the new railway, the value of trade between Afghanistan and Uzbekistan reached $\$ 732$ million in 2011-2012. The value of Afghanistan's total trade was $\$ 6.8$ billion in the same period.

\section{LESSONS}

ADB's Hairatan to Mazar-e-Sharif Railway Project offers lessons related to the implementation of urgent development projects in areas with high-security risks. 
Enhance supervision and coordination for tighter security. Coordination among all development partners was crucial in implementing the railway project in a high security risk area in a short span of time. The project benefitted from the willingness of various government agencies in Afghanistan to work together and the full commitment and support of the provincial government and local communities. Enhanced project supervision by ADB, through its resident mission in Afghanistan and Uzbekistan, resulted in tighter security around the construction site.

Employ faster procurement and disbursement measures. Time is an important consideration in implementing development projects in Afghanistan, especially because of adverse security concerns. Faster procurement was an important feature of ADB's Hairatan to Mazar-e-Sharif Railway Project. Advance procurement of works and consulting services, awarding of contracts, site handover, and timely establishment of a fully staffed project implementation unit had helped the project gain initial momentum. The turnkey contract, with its system of rewards and penalties, and the comprehensive security arrangements, with advance administrative approvals, sent the project at full speed. ADB also expedited funds processing and release to fast-track railway construction.

\section{Keywords:}

rail transport, railway, train, Hairatan to Mazar-e-Sharif Railway Project, cross-border trade, conflict, humanitarian aid, land transport, Afghanistan

\section{For further reading:}

- Project web page: http://www.adb.org/projects/42533-022/main\#project

- Building Afghanistan's New Railway as Lifesaving Link: http://www.adb.org/results/buildingafghanistans-new-railway-lifesaving-link

- Afghanistan Rail System Connects to Uzbekistan: http://www.adb.org/results/afghanistan-railsystem-connects-uzbekistan

- Railway to Regional Integration: http://www.adb.org/results/railway-regional-integration

- ADB Knowledge Showcase: Innovative Project Management and Coordination Speed Up Afghanistan Railway Project: http://www.adb.org/sites/default/files/publication/31174/ afghanistay-railway-project.pdf

\section{For further information:}

- Balabhaskara Reddy Bathula, Principal Project Management Specialist, South Asia Department | bbathula@adb.org

- Tyrrell Duncan, Technical Advisor (Transport), Sustainable Development and Climate Change Department|tduncan@adb.org

- Ki-Joon Kim, Principal Transport Specialist, Sustainable Development and Climate Change Department|kjkim@adb.org

- Dongxiang Li, Lead Regional Cooperation and Integration Specialist, Economic Research and Regional Cooperation Department | dongxiangli@adb.org 


\section{Road Construction Amid Conflict: The Afghanistan North-South Corridor Project}

Afghanistan's high security risk environment was the setting of the $\$ 78.2$ million North-South Corridor Project, approved in 2006, to help the people living in Afghanistan's Central Highlands to gain better access to hospitals, schools, and vital public services. The North-South Corridor connects Afghanistan's isolated center and its remote communities to the Ring Road, the country's main highway that links major cities and commercial centers. The project improved two major roads along the corridor into two-lane asphalt-paved highways. The first is a 133.94-kilometer connection between the northern city of Mazar-e-Sharif and Dar-i-Suf district in central Afghanistan. The second road is about 86.71 kilometers long and connects Bamyan town, the poorest in Afghanistan, to Yakawlang district. Civil works were completed in April 2013.

Tight security measures for faster implementation. The project was implemented under extremely difficult security conditions on a design-build contract for faster implementation. Some portions of the road were in relatively dangerous areas. Road construction at a road segment between Mazar-e-Sharif and Dar-i-Suf was suspended under the force majeure clause of the contract, following a brutal attack that delayed construction for about 12 months.

\section{The contractor's initial design and plan did not anticipate the security situation in the} road sections. The contractor, however, demonstrated seriousness and commitment by continuing its involvement in the project. Despite significant delays mainly due to security issues and design changes, the contractor completed the road construction as required. Security issues were eventually resolved by the government and ADB's resident mission in Afghanistan through additional security arrangements.

Out of isolation. The project roads now provide better access for Afghanistan's central communities to the economic hubs on the Ring Road. Before the project, for nearly $3-4$ winter months each year, Yakawlang and Dar-i-Suf did not have any connection to major towns. Truckloads of fruits and vegetables were spoiled during the long hours it took to transport them under extreme heat.

Agricultural Yakawlang is now connected to markets through Bamyan, offering its farmers more opportunities for selling their produce, with reduced travel time. Transport costs for produce have gone down from AF2.2 to AF1.2 per kilogram. Also, women in Yakawlang are now allowed by their families to take the shorter commute to attend University in Bamyan. Meanwhile, between Dar-i-Suf and Mazar-e-Sharif, travel time has also been reduced from 8 hours to 2. Vehicle traffic has improved by over $10 \%$ on the road sections and, most importantly, vehicle operating costs have been reduced by over $45 \%$.

Lessons for projects in conflict situations. At the time of project implementation, Afghanistan was prone to terrorist attacks and road construction projects draw very little interest from contractors and consultants because of security hazards. If the risk of such attacks is high, adequate security plans and measures must be laid out and agreed upon by all parties and implemented with the support of experienced security teams. Closer coordination on security matters among the contractor, the executing agency, ADB, and other relevant parties is necessary. Remedial actions to ensure the safety of the project team throughout the duration of the construction should also be determined. 


\section{References:}

Project web page: http://www.adb.org/projects/39467-013/main

Article: Afghanistan Highway Connects Country to Central Asia and Middle East: http://www. adb.org/results/afghanistan-highway-connects-country-central-asia-and-middle-east

\section{Further information:}

Mookiah Thiruchelvam, Urban Development Specialist, Central and West Asia Department | mthiruchelvam@adb.org 


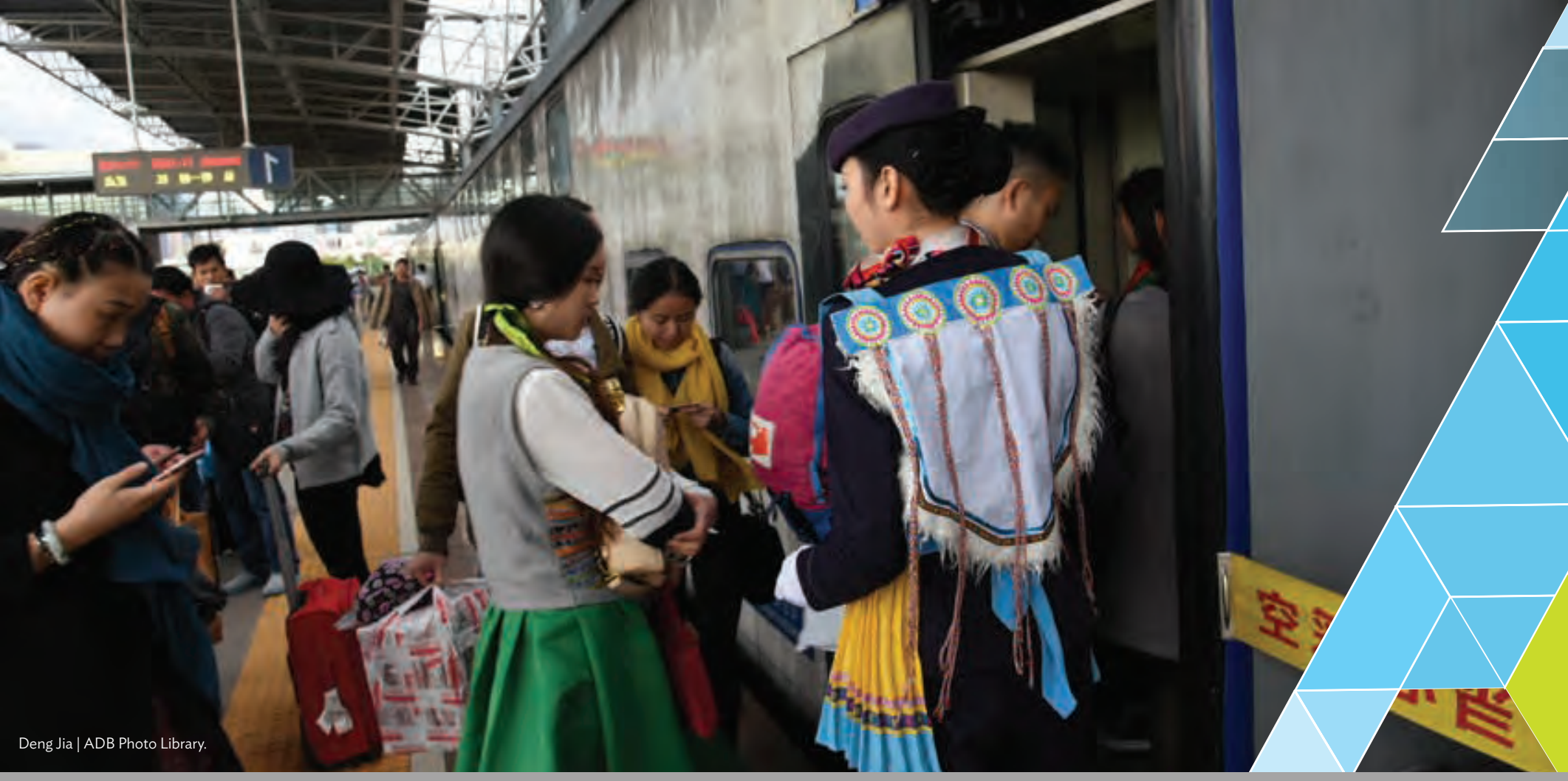

\section{A TRAIN FOR TWO CITIES:}

Railway on Rugged TerRain in the People's Republic of China

- The poor, remote northwestern region of Yunnan Province in the People's Republic of China was cut off from mainstream development due to lack of connectivity.

In 2004, ADB approved the Dali-Lijiang Railway Project which built a 167-kilometer rail line to connect the historic cities of Dali and Lijiang. The project overcame complex geological and environmental challenges through informed decisions on rail alignment and design and careful consideration of affected ethnic minority groups.

- The project provided the shortest land route between the two key cities and connected them with other major cities and ports, as well as to the Greater Mekong Subregion. The railway also contributed to significant increases in tourism revenues and employment opportunities.

ADB's Dali-Lijiang Railway Project offers lessons that could help inform other future railway projects. The West Yunnan Railway Company has already successfully applied the following key lessons in its subsequent railway project designs. 


\section{CONTEXT}

M

ountainous terrain that includes fragile protected areas of environmental and historical significance impeded access to the northwestern region of Yunnan Province in the People's Republic China (PRC). The limited road network, poor road condition, and high transport costs all contributed to the lack of connectivity, particularly between the key cities of Dali and Lijiang. The tourism industry was constrained and development moved at a snail's pace. Northwestern Yunnan needed better transport connectivity to bring much-needed economic growth in the region.

Yunnan Province in the southern PRC is endowed with rich natural resources, cultural diversity, and picturesque tourist destinations. The historic cities of Dali and Lijiang in Yunnan's northwestern region offer several tourist destinations to domestic and international travelers.

Dali City is home to the Cangshan and Erhai National Nature Reserves, which encompass the Cang Mountain, Erhai Lake, Three Pagodas, Snake Bone Tower, Butterfly Spring, Gantong Temple, ancient Dali town, and the Bai Folk House Complex. Further up north, Lijiang City features the Yulong Snow Mountain, Lugu Lake, Laojun Mountain, and the old Lijiang town, which was declared a United Nations Educational, Scientific and Cultural Organization (UNESCO) world cultural heritage site. These valuable sites lie against a background of alpine ice and snow sceneries, plateau meadows, and primitive forests.

\section{PROJECT SNAPSHOT}

People's Republic of China: Dali-Lijiang Railway Project

Approval date:

DECEMBER 2004

Amount:

\$180 MILLION LOAN

Borrower:

GOVERNMENT OF THE

People's Republic of China

Executing agency:

West YUNNAN RaILWAY COMPANY

Geographical location

YunNan PRovince,

People's Republic of China

Transport project: RAIL

Completion date: JULY 2012

Remote and generally poor, northwestern Yunnan is among the least developed areas in the PRC. Of the 1.1 million potential beneficiaries, about $75 \%$ were rural and $30 \%$ were poor. About $73 \%$ were ethnic minorities: Bai (46.2\%), Naxi (18.3\%), Yi (3.2\%), and Lisu (2.8\%).' Two major factors hindered economic growth: lack of connectivity and high transport costs. The area's road network was limited and in poor condition. ${ }^{2}$ Bus travel from Kunming, the province's capital, to Lijiang took about 8 hours and cost CNY180-CNY240 per trip. To get to Dali from Lijiang, a 4-hour land travel which cost CNY60-CNY70 per trip was the only option. For freight, the road tariff was CNYo.65 per tonkilometer.

In 2004, ADB approved the Dali-Lijiang Railway Project to improve access to the remote, underserved, and poor rural region of northwestern Yunnan. The Ministry of Railways served as the project's executing agency, while the West Yunnan Railway Company implemented the construction of a 167-kilometer railway that connected the poor towns of Dali to Lijiang in northwestern Yunnan, thus opening access to major cities within the province, to ports within the country and in Viet Nam, and to other countries in the GMS.

Building a railway in this remote area came with several challenges. The difficult terrain and the cultural heritage and tourist spots in the project site were major factors to consider. The railway

1 ADB. 2004. Report and Recommendation of the President to the Board of Directors: Proposed Loan to the Peoples' Republic of Chinafor the Dali-Lijiang Railway Project. Manila.

2 ADB. 2003. Technical Assistance to the People's Republic of China for Preparing the Dali-Lijiang Railway Project. Manila. www.adb.org/sites/ default/files/projdocs/2003/tar_prc_36432.pdf 
construction had to be designed to adjust to the topography without marring the tourist spots and further harming the soils and slopes which were already prone to erosion.

Another factor was the high number of ethnic minorities in the project area, including the boundary of impact. ${ }^{3}$ Their unique and diverse customs and cultural traditions made the project area a major tourist destination. The project design entailed extensive consultations and careful consideration of the concerns of ethnic minorities. Although the project would help ethnic minorities gain access to more markets and services, the West Yunnan Railway Company had to ensure it would not adversely affect their cultural values and socioeconomic systems. Their cultural identity may be undermined by the influx of travelers and businesses. The impact assessment and agreed actions were included in the ethnic minority development plan endorsed by the Ministry of Railways and the West Yunnan Railway Company.

\section{SOLUTIONS}

ADB's Dali-Lijiang Railway Project used several key measures that ensured the technical soundness of the railway's design while minimizing its social and environmental impacts.

Right rail alignment. The project site sits amid the Yunnan-Guizhou plateau and Hengduan mountains, which has elevations ranging from 1,900 meters to 2,300 meters. These mountains, rising from east to west and from south to north, huddle over two major river systems with corresponding

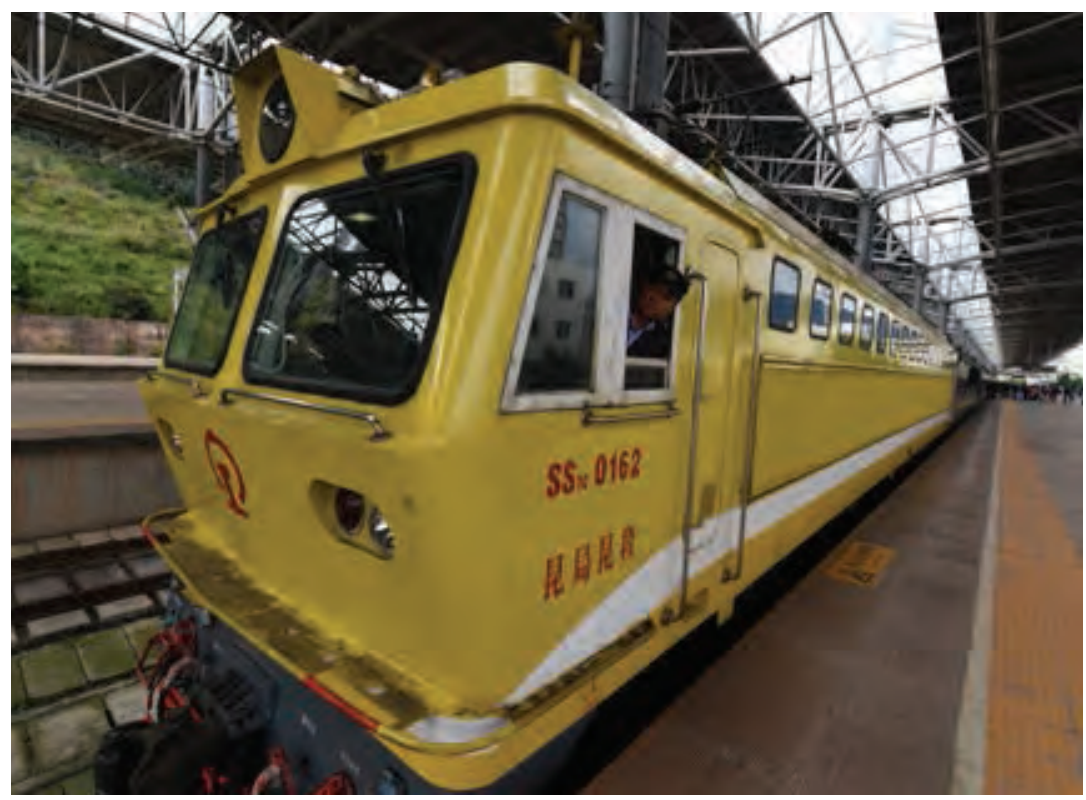

Dali-Lijiang railway is designed with a speed of 120-kilometers per hour. Deng Jia | ADB Photo Library. tributaries. The riverbeds are deep and the slopes surrounding them are steep. Erhai Lake, which lies atop a geological fault, is also situated within the project area. Thus, finding a suitable railway alignment was a major challenge for the project. Three rail alignment options were explored. The first option was for the railway to go through the mountains west of Dali and passing through its scenic spots. The second option was for the railway to run parallel to the Dali Highway, passing through the cultural and heritage areas. The third option was for the railway to be built along the east side of Erhai Lake, which will not impact key tourist areas and large populations. This third option was ultimately chosen since it offered minimal impact to the environment, cultural sites, and residents. There were fewer mountains to go through, less farmland to be acquired, and fewer businesses to relocate.

3 This project was initially opposed by the Tibetan lobby which led to additional studies and consultations in the area to the north of Lijiang, referred to as the boundary of impact. These findings were included in the ethnic minorities development plan. http://www. adb.org/projects/documents/dali-lijiang-railway-project-ethnic-minorities-development-plan-emdp 
Right railway design. Designing the railway to suit the chosen alignment was another challenging step. Although the chosen alignment offered the least environmental disturbances, the rail line would pass through rivers, watershed areas, and mountains. The project completed 11.4 million cubic meters of earthwork and rockwork to make a 70.8-kilometer roadbed for the main line. Construction of the roadbed entailed deep cutting in 34 sites. Five steep embankments with heights over 20 meters and 77 bridges with a total length of about 26.253 kilometers were also built. The project also had to burrow through mountains to create 45 tunnels with a total length of 78.6 kilometers. The bridges comprised $15.7 \%$ and the tunnels made up $41.9 \%$ of the total railway length.

Stabilized treacherous terrain. Almost half of the project area sits on severe soil erosion regions. As the project entailed deep excavations and construction works, vegetation would be affected, which would contribute to further soil erosion. The project used several measures to minimize loss of soil. It optimized design and regulated earthwork to enhance the rail's horizontal section line, thereby reducing the amount of excavation and spoils. Each completed construction segment or earthwork was immediately followed by filling and revegetation. The slopes of the roadbed were safeguarded using a variety of protection measures, namely mortar rubble slope protection, dry-laid rubble slope protection, and vegetation slope protection. Retaining walls were also established. These measures reduced the volume of soil loss caused by the construction of the roadbed, stations, and yards to 31,200 tons per annum, for a total of 93,600 tons over the construction period. ${ }^{4}$

Support for cultural preservation and tourism development. The project supported cultural preservation and tourism development in two ways: an accompanying technical assistance which trained locals in cultural preservation and its integration with tourism development and the Ethnic Minorities Development Plan which specified actions, including the incorporation of tourist facilities into rail operation design. The technical assistance package enabled local government officials, local artists, academics, and village residents to exchange ideas on practical strategies that they can use to harmonize cultural preservation with tourism development. ${ }^{5}$ Lessons from these seminars were eventually applied to five pilot activities in different areas within the project area. The seminars and pilot activities ensured that the entry of more tourists in the area would not overwhelm or adversely impact the cultures and traditions of local ethnic groups. To facilitate the entry of more visitors, the project included tourist coaches into its railway operation.

Stakeholder consultation and project ownership. Extensive consultations among over 4,000 stakeholders, including ethnic minorities, were conducted to help project implementers understand the public's perception about the railway, inform environmental and social assessments, and prepare the resettlement plan and an ethnic minority development plan. The consultations revealed that, generally, there was widespread support for the project and people were looking forward to the benefits and opportunities opened by the project. The consultations also ensured the people's active involvement during project implementation and railway operation, helping them gain ownership of the railway project.

Complete connection. One important value addition to the project that expanded the project's benefits to more people in the province is how it went beyond the rails to reach out to northwestern Yunnan's interior areas. About 139 kilometers of access roads were constructed to connect the railway stations to the nearest counties or townships. ${ }^{6}$

4 ADB. 2004. Summary Environmental Impact Assessment. The Dali-Lijiang Railway Project. Manila.

5 ADB. 2008. Technical Assistance Consultant's Report. Support to Ethnic Minorities' Development Plan. The Dali-Lijiang Railway Project. Manila. www.adb.org/sites/default/files/projdocs/38587-PRC-TACR.pdf

6 ADB. 2013. Completion Report: Dali-Lijiang Railway Project in the Peoples' Republic of China. Manila. 


\section{Results}

ADB's Dali-Lijiang Railway

Project has provided

many benefits to various

stakeholders, such as

connectivity, increased

incomes, tourist volumes, and

a livelier local economy.

\section{Connectivity and regional \\ integration. The railway}

has provided connectivity

from northwestern Yunnan

province to its capital,

Kunming, and even to major

cities such as Shanghai and

Beijing, through a link with the

country's national rail corridors.

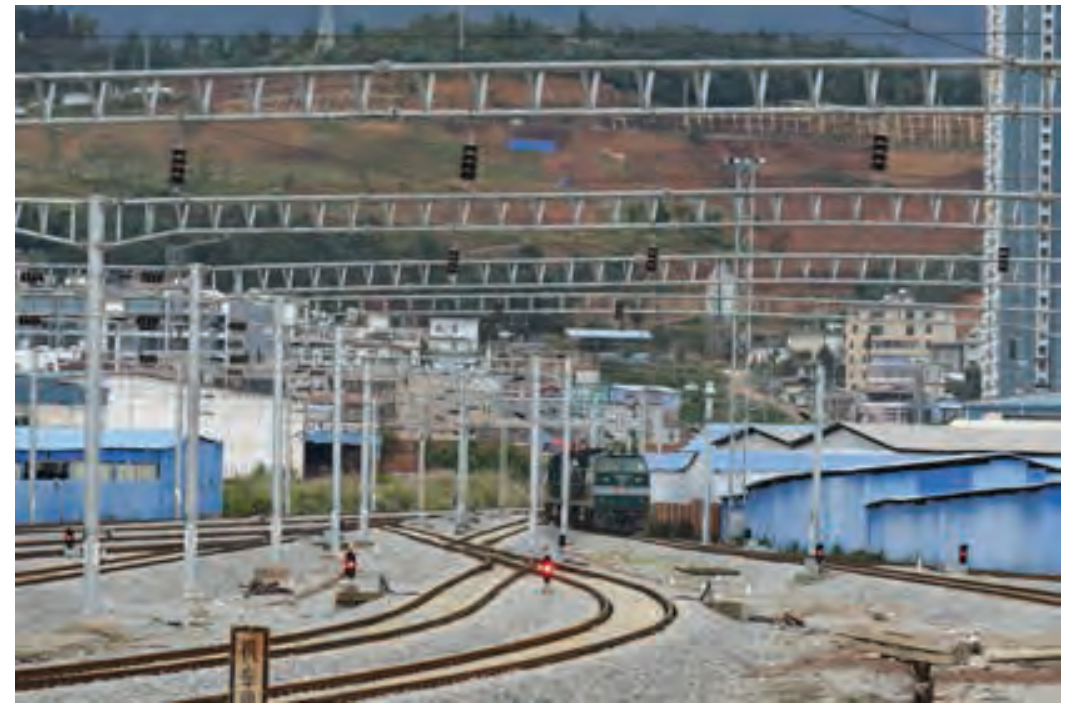

Dali-Lijiang Railways. This single track railway is the shortest overland traffic line between Dali-Lijiang. Deng Jia | ADB Photo Library.

The capacity of its passenger

trains ranges from 980 to 1,190 per trip. At the beginning, only $28.8 \%$ of train capacity was filled.

After 12 months, passenger numbers increased to $92 \%$ of capacity, equivalent to about 1,305,000 passengers. In addition, it has drastically reduced travel time and cost-going to Lijiang from Dali now cost only half of its previous amount, while travel time from Kunming to Lijiang was cut from 18 hours to nine, and travel cost was drastically reduced from CNY240 per trip to CNY75. This railway is also part of efforts to enhance regional cooperation in the GMS. It connects to the Pan-Asian railway as well as the port of Hai Phong in Viet Nam?

Socioeconomic benefits. The most recent validation report for the project rated its socioeconomic impact as significant, as the project has contributed to lowering the cost of living in Lijiang. It also made available a wider range of products, compared with 2004. Since the railway became operational, prices of various products decreased and were only slightly higher than those in Kunming.

Cultural preservation. The railway has not compromised local culture in northwestern Yunnan. The accelerated growth and tourism had started before the project and did pose serious risks. The implementation of the Ethnic Minorities Development Plan contributed to greater awareness of these risks and the need to preserve and develop the intangible cultural heritage. The pilot cultural preservation projects, initiated by the project's accompanying technical assistance package, showed that cultural preservation can be successfully integrated into local economic development, and can also be a focal point for tourism. Further, the project demonstrates how the railway supported the local tourism industry, enabling it to achieve higher incomes by providing a lower-cost and faster option to visit the province.

7 While the project was not a part of any transport corridor under ADB's Greater Mekong Subregion (GMS) Program, Dali is within the GMS northwestern corridor, allowing users of the project to gain the extra benefit of access to the GMS rail network from Dali. ADB. 2014. Validation Report. The Dali-Lijiang Railway Project. Manila. http://www.adb.org/sites/default/files/PVR-387.pdf 


\section{LESSONS}

ADB's Dali-Lijiang Railway Project offers lessons that could help inform other future railway projects. The West Yunnan Railway Company has already successfully applied the following key lessons in its subsequent railway project designs.

Determine the best option for railway alignment.

Considering the conditions surrounding this project's railway alignment and the livelihoods and trade of the affected population, the project chose an option which will not only cause minimal harm to the environment and residents but also capitalize on and bolster existing industries. The alignment of the railway did not only open markets and services, it helped

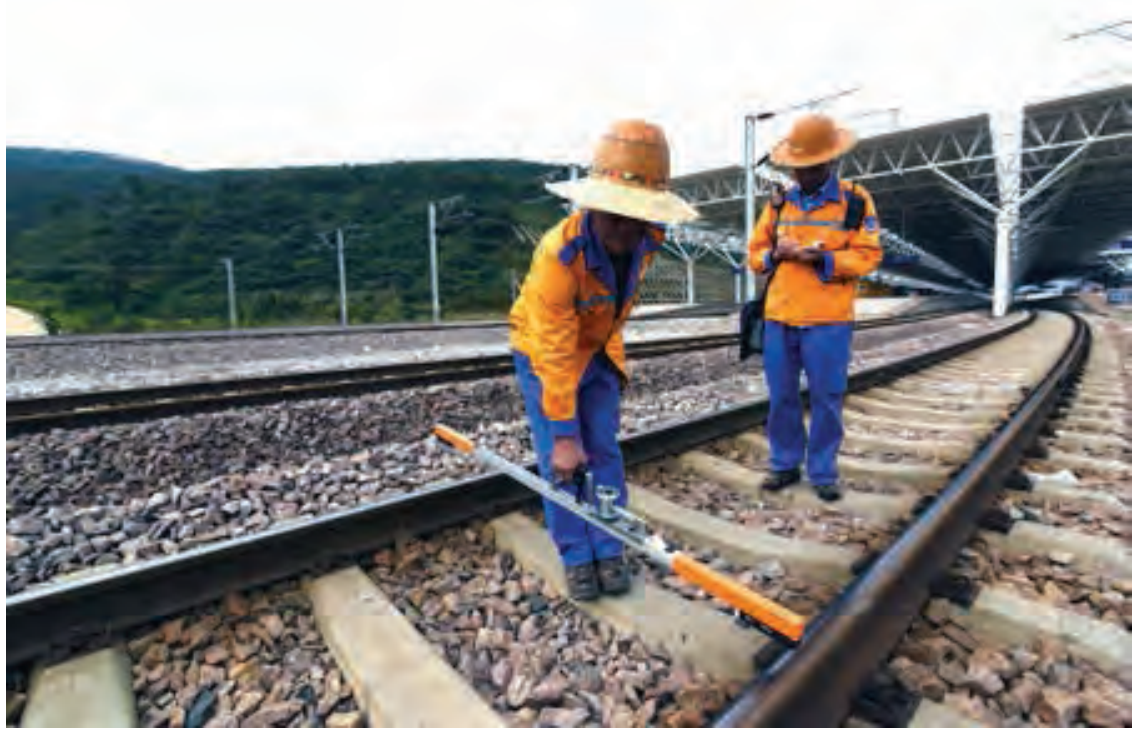

Railway maintenance by workers of the Lijiang Railway Station. Deng Jia | ADB Photo Library.

pushed tourism in the province, which was a pillar of Yunnan's economy.

Optimize design, construction, and operation. The project further provided connectivity by making the railway stations accessible to remote towns through the construction of 139 kilometers of access roads. While providing access to remote areas, the Dali-Lijiang Railway also became part of the province's tourism industry through the Ethnic Minorities Development Plan that prepared residents for the bigger influx of tourists brought about by the increased connectivity and incorporated tourism facilities into the project design, such as tourist coaches. Thus, the railway, aside from providing a less-expensive passenger and freight transport option, became an integral part of a thriving local economy that provides additional income to the province.

The project is situated in a mountainous area with abundant flowing rivers and historical, cultural, and tourism sites along its route. Underneath this picturesque scene is soil prone to erosion. The project had to make adjustments, not just with alignment, but with the design of the railway. Transport projects do not only need to adjust to the environment, but they need to include, as the project validation report recommended, a continuous process of adaptation to the latest construction and operation technology and more environment friendly solutions.

Forecasts on cost and traffic should be realistic. Transport projects may experience delays and setbacks if it fails to realistically estimate what works need to be done and their corresponding costs. Any construction works should be planned and agreed on at the onset, and each work should have a corresponding cost that provides contingencies on probable price variations. This project 
experienced delays in loan closing primarily because of negotiations on pricing for additional works or variations. In addition to meticulous cost and works estimation, traffic forecasts must be carefully and realistically made as this has implications on project impact and outcome. The project's traffic forecasts were deemed overly optimistic by the validation report; it failed to consider the rural or greenfield nature of the site, which would necessitate efforts to attract bus and private vehicle users to use the rail.

Conduct extensive consultation. The extensive consultation during planning, design, and construction helped promote the local people's ownership and responsibility for the project. Dialogues and consultation meetings were done to inform design, construction, safeguards, job opportunities, ethnic minority culture protection, gender, and social impacts. These consultations made the design relevant, the whole project more sustainable, and allowed stakeholders to have a real voice in the proposed infrastructure, which eventually facilitated their ownership of the project. Ownership is important, as this case illustrates, since it can ensure commitment to project implementation and eventually operation, even when confronted with difficulties. More importantly, the stakeholders' ownership of the project ensured that the latter was well integrated with not just the terrain on which it stands, but with the way of life and businesses of the various ethnic minorities and cultures in the site.

\section{Keywords:}

Rail, railway, trains, connectivity, tourism, cultural preservation, environmental preservation, DaliLijiang Railway Project, land transport, People's Republic of China

\section{For further reading:}

- Project web page: https://www.adb.org/projects/36432-013/main

- Technical Assistance page: https://www.adb.org/projects/36432-012/main

- Railway Brings Trade, Tourism, and Development to Yunnan: https://adb.exposure.co/railwaybrings-trade-tourism-and-development-to-yunnan

\section{For further information:}

- Xiaoxin Chen, Senior Transport Specialist, East Asia Department |xchen@adb.org

- Tyrell Duncan, Technical Advisor (Transport), Sustainable Development and Climate Change Department |tduncan@adb.org

- Ki-Joon Kim, Principal Transport Specialist, Sustainable Development and Climate Change Department|kjkim@adb.org

- Dongxiang Li, Lead Regional Cooperation and Integration Specialist, Economic Research and Regional Cooperation Department | dongxiangli@adb.org 


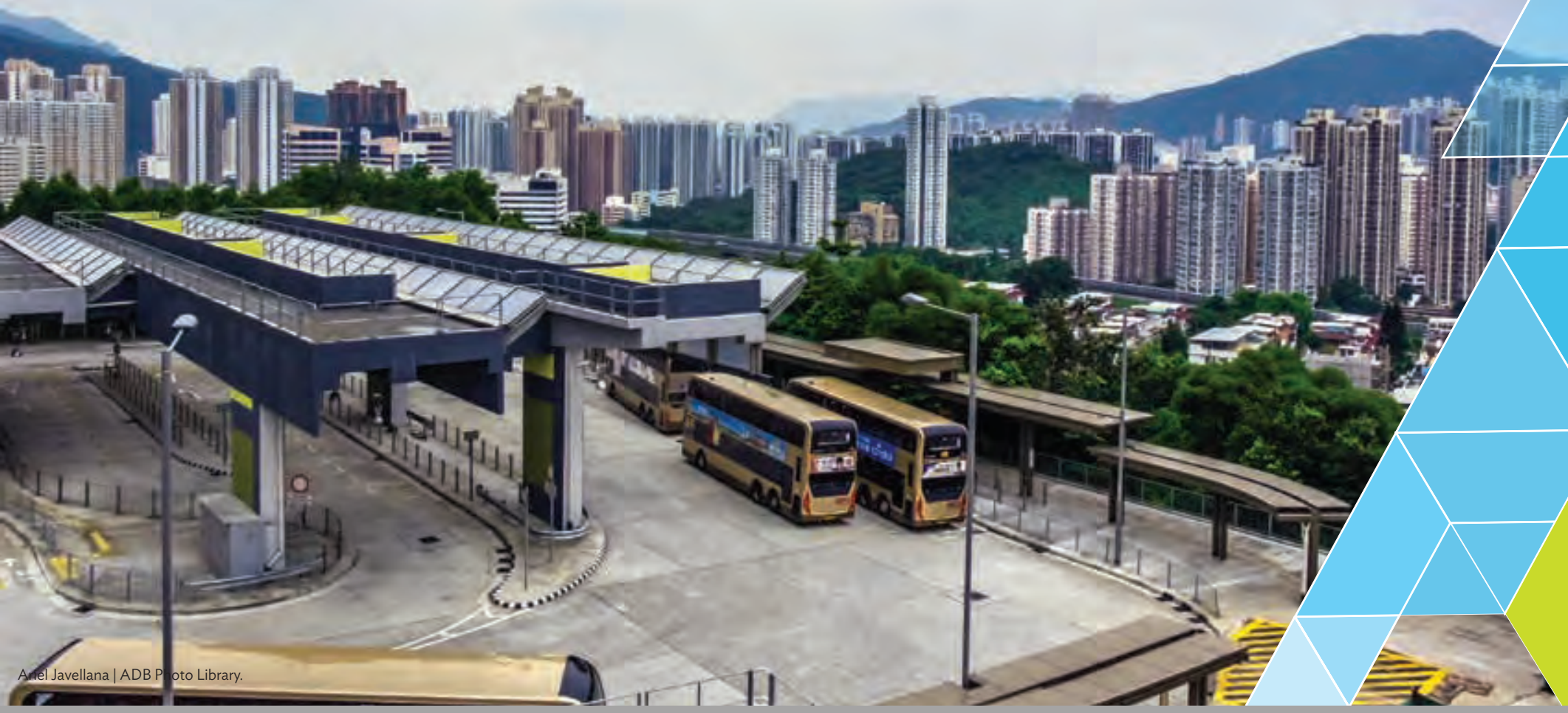

\section{Public Transport for a New City Center:} Urban Options In the People's Republic of China

Lanzhou, the biggest city in Gansu Province in the People's Republic of China, has congested city streets, polluted city air, and unsafe roads for pedestrians and nonmotorized vehicles.

In 2008, ADB approved the Lanzhou Sustainable Urban Transport Project to help implement the city master plan to decongest the city. The master plan introduced a Bus Rapid Transit system, improved options for nonmotorized transport, and has safety and environment-friendly features.

Lanzhou now enjoys the multiple benefits of the project, such as decongestion, reduced emissions and pollution; and a convenient, fast, and affordable transport system.

In implementing similar sustainable urban transport projects, the project recommends careful study of city traffic, the involvement of expert partners, and learning from similar successful projects through knowledge-sharing activities and study visits. 


\section{CONTEXT}

\section{anzhou, the biggest city in the northwestern province of Gansu in the People's Republic of China (PRC), suffered from severe traffic congestion, air pollution, and road safety issues. With a}

growing population of more than four million people, Lanzhou's urban transport problems are expected to worsen in the coming decades. The city needed a safer, more affordable and efficient, and environment friendly urban transport system that would decongest clogged main avenues and major streets and offer sustainable transport options to its citizens.

Lanzhou is the economic, political, and cultural center of Gansu province and is one of the major transport hubs between the eastern and western regions of the PRC. The city is divided by the Yellow River. Businesses, schools, and government converge in three districts on the south bank, while mostly residences, schools, and universities occupy the northern district of Anning. Heavy motorized and nonmotorized traffic is a daily feature all four districts which occupy only $8.5 \%$ of Lanzhou's land area but account for $62.9 \%$ of its total population. Population densities in the south side have reached as high as 18,000 people per square kilometer in some areas, making expansion impossible. Anning, on the other hand, has huge potential for expansion as $80 \%$ of its land is suitable for settlement and the population density is only 3,400 people per square kilometer. The Lanzhou Municipal Government introduced a master plan that aimed to develop Anning into a second business district to decongest the zones south of the river through the construction of more roads and rails. This way, land use can be optimized, as well as the economic and social functions of the city.

However, a second city center in Anning would pose another set of problems. It would increase transport demand to, from, and within the district. Moreover, Lanzhou already had a growing congestion problem. Project preliminary studies showed that demand for public transport in Lanzhou will more than double from 2005 to 2020, the number of registered passenger vehicles will increase roughly seven-fold, and the number of buses will double. Traffic demand in Anning will practically triple from 2008 to 2020. This projected rise in vehicle volume will compound the issue of air pollution already being felt in the city. In 2011, Lanzhou was reported to have the worst air pollution in the country.

In Anning, walking constitutes $56 \%$ of person trips and bicycles, $22 \%$. The municipal master plan projected the decline to $44 \%$ and $16 \%$ respectively by 2020 . Moreover, many junction and roadway designs were not optimal for pedestrian and cyclist safety and the city lacked a network of protected or separated bicycle lanes. Some nonmotorized transport lanes were even used by motor vehicles for passing through and parking. Bicycle parking facilities at key locations such as bus stations, shopping centers, and public facilities were also insufficient.

1 ADB. 2010. Sustainable Development Series. Manila (June). http://adbdev.org/sites/default/files/publications/28557/file/adb-wp13inclusive-growth-infrastructure.pdf 
The Government of the PRC and the Lanzhou Municipal Government were seeking solutions to the negative consequences of rapid urbanization. They had a master plan to decongest Lanzhou by developing another city center, but it was focused on building new roads. With ADB's assistance, the masterplan was refined and initial studies revealed that a mass transit based on a Bus Rapid Transit system would be a better solution to ease traffic congestion in Lanzhou.

In 2008, ADB approved the Lanzhou Sustainable Urban Transport Project to assist the Lanzhou Municipal Government in facing the challenges that come with city expansion. The project, the first to support an urban mass transport service, took a holistic approach by considering sustainability in every aspect of project design, from the transport system to be used, the road networks to be built and rehabilitated, the impact to the environment, and traffic demand management and safety issues.

To oversee implementation, the city government established a project steering committee, chaired by the deputy mayor of Lanzhou. A project management office was established to coordinate project management; supervise procurement of works, goods, and services; monitor loan utilization; and prepare reports. In addition, the provincial government, which had prior experience in designing and implementing ADB-assisted transport projects, shared its knowledge and experience in transport project implementation. Several study visits by senior city officials to another Bus Rapid Transit site enabled them to visualize the same system for Lanzhou and win the support of stakeholders. Guided by the refined master plan, the Bus Rapid Transit system was completed before the target completion date and was officially opened to the public on 28 December 2012. Since then, the bus system has experienced rapidly increasing passenger volume.

\section{SOLUTIONS}

ADB's Lanzhou Sustainable Urban Transport Project conducted extensive consultations for developing and finalizing the project design to maximize benefits and minimize urban and environmental impacts.

Sustainable transport option. The project introduced a Bus Rapid Transit system, a relatively new urban transport option that is of high capacity and yet with low cost. Bus Rapid Transit systems can be planned, designed, and implemented much more quickly, at less than $10 \%$ of the cost than underground metros. It is a full-scale permanent, integrated system which uses buses running on dedicated lanes to quickly and efficiently transport passengers to their destinations, with the flexibility to meet changes in transit demand.

Lanzhou's Bus Rapid Transit system runs through the heart of the Anning district, on a 12-kilometer corridor, nine of which are operational, and offers 15 weather-protected stations with seven routes. It features a new split-station concept, the first in the world, which allows buses traveling in the same direction to stop on both sides of a boarding platform. Another design innovation was the development of enclosed cold-weather stations.

Improved options for nonmotorized transport. The project also included better options for nonmotorized transport, including bicycle access lane, bicycle parking, and pedestrian walkways. The bicycle access lanes are 3.5-5.0 meters wide, located between sidewalks and carriage lanes, while bicycle parking facilities were made available at bus stations. Pedestrian walkways, $3-7$ meters 
wide, include underground passageways at various points along the Bus Rapid Transit corridor.

Safety and environment-friendly features. The project integrated an advanced traffic control system that addresses pedestrian and motorist safety concerns. The system also provides data for road maintenance, road and transport planning, and environmental monitoring.

By improving the mass transport system and promoting nonmotorized transport, the project would reduce transport energy consumption and carbon emissions, which, in turn, could help mitigate climate change. The project included an application to the United Nations Framework Convention on Climate Change to gain carbon credits under the Clean Development Mechanism, which makes it the second Bus Rapid Transit system so far to be registered.

Extensive consultations on project design. The project design was guided by extensive stakeholder consultations and collaboration. Household surveys and group discussions were conducted among people who will be affected by road construction and rehabilitation, residents of the project area, and transport users. Consultations were carried out with relevant local government agencies, and also with peoples' organizations such as the All China Women's Federation and the Disabled People's Federation. Consultations continued and collaboration was encouraged until the finalization of project design. These enabled the integration of stakeholder inputs into the design and the contextualization of the project's approach according to the current and future needs of the city.

\section{RESULTS}

ADB's Lanzhou Sustainable Urban Transport Project has provided a better mass transport system that is more sustainable because of complete project ownership by the Lanzhou Municipal Government.

Better and greener transport system. One of the most obvious successes of the project is the steadily growing ridership of the Bus Rapid Transit system. A month after its opening, the system has transported 100,000 passengers daily, which grew to about 290,000 in September 2013. It has become the second highest-capacity Bus Rapid Transit system in Asia.

People from various sectors have also expressed appreciation of not just the bus system, but the whole project. The Gansu Daily has reported the positive impacts of the bus system, based on the statements of passengers, Lanzhou Project Management officials and staff, the Lanzhou Bus Company, traffic policemen, and real estate developers. Passengers praised the speed, convenience, free transfers, and climate-proof stations. A government official from Anning District said that the bus system stimulated real estate, commercial, entertainment, and tourism development. It has led to the development of the 5th Avenue Shopping Center, located underneath the system's corridor. The Dacheng Investment Company, which invested in the shopping mall, said that it now has 270 shops, over 1,000 employees and increasing revenues. Traffic police said it helped reduce traffic congestion and traffic collisions. The Lanzhou Bus Company shared that it received 6 RMB million (US\$1 million) for selling $\mathrm{CO}^{2}$ emission rights from the project.

The Institute for Transportation and Development Policy conducted a preliminary impact analysis of the bus system and reported that bus boarding and alighting time has drastically reduced. Lanzhou's 
residents have also reported increased satisfaction on the city's mass transit, from $49 \%$ before the project to $73 \%$ since the bus system started operation. The impact analysis surveys also showed a significant increase in civic pride and appreciation of environment quality and livability. The surveys also showed reduced wait times and travel costs, and improved perceptions of safety among passengers, cyclists, and pedestrians.

Project ownership by the city government. The success of the project would not have been possible without the crucial steps that ignited the interest and support of government officials and the affected population. These steps-extensive stakeholder consultation and collaboration, knowledge sharing, and a customized yet groundbreaking urban transport system-led to a holistic project design that improved not only mass transport, but pedestrian- and nonmotorized mobility, and the environment as well.

These steps, primarily done during the project preparation and design stage, have positively influenced the whole project implementation process. The project management office formulated and implemented a social development action and monitoring plan, again based on consultation and collaboration with key stakeholders to guide project implementation. This plan details inclusive social measures that enhance the project's benefits for local people, including farmers, women, the elderly, the disabled, and children.

These crucial steps have encouraged the Lanzhou Municipal Government to truly own the transport project. It fast-tracked the bus system's opening before its scheduled launch and has initiated PPPs to further develop the six underground malls below the system's corridor. It has also further improved options for nonmotorized transport by providing double-tier bike parking racks near the bus stations, and is currently gearing up for a wide-scale bike-sharing system and greenways. The city is also now proceeding with extending the bus system city-wide.

The extensive stakeholder consultations, knowledge sharing, and an innovative yet sustainable transport option have indeed transformed Lanzhou's initial low-grade urban master plan into a sustainable urban transport project that has literally changed the face of the city. The Lanzhou Bus Rapid Transit system has been recognized not just within the country, but throughout the world and was one of only four transport projects honored at the 2014 Sustainable Transport Awards.

\section{LESSONS}

ADB's Lanzhou Sustainable Urban Transport Project offers lessons in implementing urban transport projects to help alleviate traffic congestion and air pollution in large and growing cities.

Study city traffic. The initial city masterplan was based on road and rail building. When city officials requested $A D B$ to help improve the masterplan, ADB first conducted project preparation studies that eventually determined that a mass transport option with improved nonmotorized transport options was a better solution to the traffic congestion experienced in the city. Walking (56\%) and biking (33\%) constitute the bulk of person trips but the city's junction and roadway designs were not optimal for pedestrian and cyclist safety. The studies also showed that public transport demand will more than double within 15 years and traffic demand in Anning will practically triple within 12 years. 
Involve expert partners. By collaborating with partners, ADB brought word class experts to assist in the preparation, design, and implementation of the project, specifically covering specialized fields such as bus rapid transit and nonmotorized transport. The partnership approach would also enhance local skills and capacities through on-the-job training and other capacity-building activities.

Conduct knowledge-sharing activities. The city officials who were initially skeptical about the project started to see how a sustainable transport system can help them through a series of knowledge-sharing activities and study tours. Observing other Bus Rapid Transit systems in operation allowed them to have a deeper understanding of the project, what it offers, and how such a system can work in Lanzhou. This was supported by further sharing of knowledge and experiences by the provincial government of Gansu, which has previous experience in implementing ADBfinanced transport and urban projects.

\section{Keywords:}

Bus rapid transit system, nonmotorized transport, urban mass transport, bus, Lanzhou Sustainable Urban Transport Project, land transport, People's Republic of China

\section{For further reading:}

- Project web page: https://www.adb.org/projects/40625-013/main

- Lanzhou's Bus Rapid Transit System Brings Quick Relief to Busy City: https://www.adb.org/ publications/lanzhous-bus-rapid-transit-system-brings-quick-relief-busy-city

- Bus Rapid Transit Provides Win-Win Solution to PRC's Lanzhou City: https://www.adb.org/ results/bus-rapid-transit-provides-win-win-solution-prcs-lanzhou-city

\section{For further information:}

- Tyrell Duncan, Technical Advisor (Transport), Sustainable Development and Climate Change Department|tduncan@adb.org

- Ki-Joon Kim, Principal Transport Specialist, Sustainable Development and Climate Change Department|kjkim@adb.org

- Dongxiang Li, Lead Regional Cooperation and Integration Specialist, Economic Research and Regional Cooperation Department | dongxiangli@adb.org 


\section{CONTEXT}

T raffic congestion constrains daily activity in the busy city of Yichang. Public reliance on private vehicles and transshipment transport combine to clog city streets. Congestion worsens everyday due to population increase and the problems that accompany rapid urbanization that could curtail economic growth. Yichang needed to solve its urban transport problem quickly and decisively.

Yichang, which symbolizes prosperity in Chinese," is going through major changes. The city is the second largest in Hubei Province, People's Republic of China is growing rapidly. It has five counties, three sub-cities, and five districts, covering an area of 21,000 square kilometers, with a total population of 4.1 million people. ${ }^{2}$ About half of the city's population lives in the 828 square kilometers of urban area. Its urban population is projected to increase to 2.8 million by 2030 due to continuing migration. In 2010, Yichang's per capita GDP was CNY38,181, higher than the provincial averages of CNY27,906 and the national average of $\mathrm{CNY}_{37,977.3}$

Several factors cause city congestion. One of these is the people's increasing reliance on private vehicles. About $75 \%$ of all person-trips are made with private means of transport, mainly concentrated in the central business district. This is exacerbated by illegal parking and hawking, as well as inefficient enforcement of traffic regulations. This mishmash of traffic woes has rendered mass transport ineffective.
PROJECT SNAPSHOT

People's Republic of China: Hubei-Yichang Sustainable

Urban Transport Project

Approval date:

August 2013

Amount:

\$150 MILLION LOAN

Borrower:

GovernMENT OF THE

People's Republic of China

Executing agency:

Yichang MUNICIPAL

GOVERNMENT

Geographical location:

Yichang, People's Republic of CHINA

Transport project: ROAD (URBAN)

Completion date: 2017

Another factor is transshipment transport, since Yichang's major roads are important arteries in inter-regional traffic. The Three Gorges Dam, which lies at the northern tip of the city, brings in huge bi-directional freight volume to the city. In 2010, it reached 90 million tons, and this is projected to increase to 185 million tons in 2020 and 248 million tons in 2030. The dam has limited ship-lock capacity, thus traffic requiring pass-dam transshipment could also increase from 12.4 million tons in 2010 to 85 million tons in 2020, and 148 million tons in 2030. This presents a huge challenge for the city-its major streets are already stretched by daily urban commute. A bypass road is needed to handle this traffic growth without causing more congestion and traffic safety issues in the city. ${ }^{4}$

While Yichang is fast developing into a modern logistics hub, its industries are also growing at an accelerated pace. Aside from water-based transport, expressways and railways also converge in Yichang, while an airport is also currently being developed. To sustainably support this growth, access to the logistics facilities, inland waterways, the airport, and the central business district must be improved.

1 Yichang Municipal People’s Government Information Office. April 2012. Yichang overview. http://www.yichang.gov.cn/col/col29110/ index.html

2 ADB. 2013. Report and Recommendation of the President to the Board of Directors: Proposed Loan to the People's Republic of China for the Hubei-Yichang Sustainable Urban Transport Project. Manila (July).

3 ADB. 2013. Environmental Impact Assessment. People's Republic of China: Hubei-Yichang Sustainable Urban Transport Project. Manila (June).

4 ADB. 2013. Report and Recommendation of the President to the Board of Directors: People's Republic of China for the Hubei-Yichang Sustainable Urban Transport Project. Manila (July). 


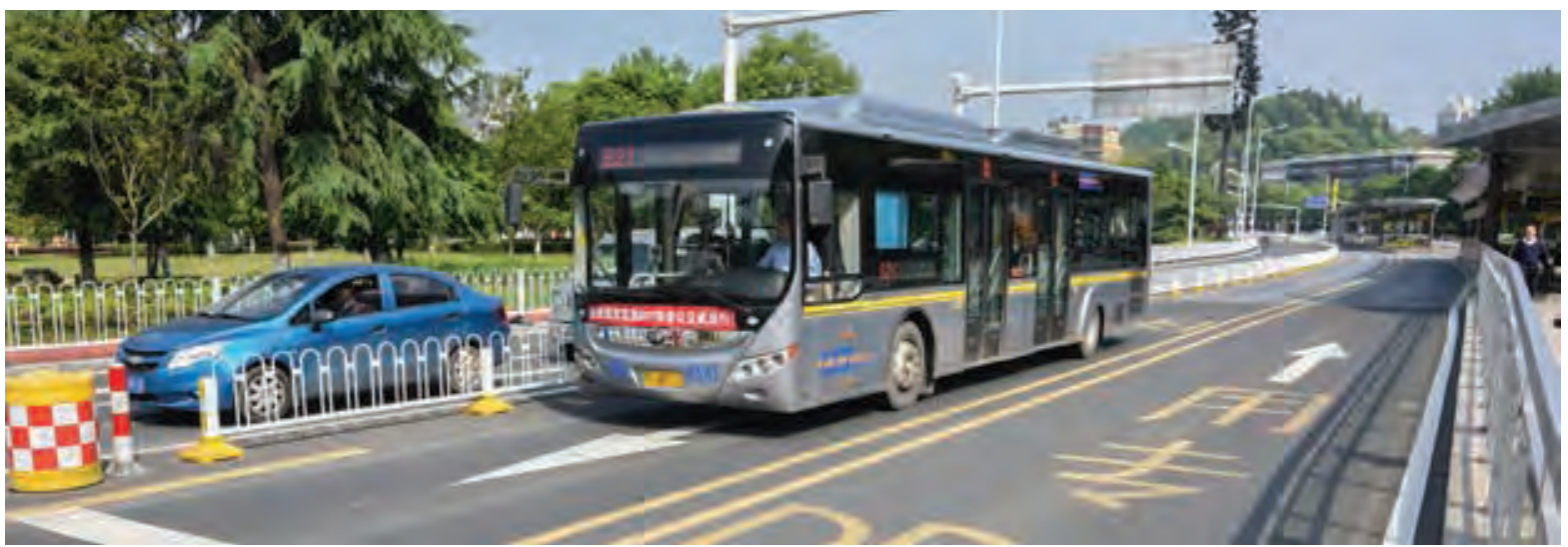

The Bus Rapid Transit system offers convenient and flexible transport option to commuters.

Deng Jia | ADB Photo Library.

The Government of the People's Republic of China, with ADB assistance, aimed to address these challenges through the Hubei-Yichang Sustainable Urban Transport Project. The project was initiated in December 2011 and introduces a Bus Rapid Transit system along the main arterial road of the city and a bypass road to carry freight traffic and connect newly developing urban and industrial areas. The bus system provides a greener mass transit option augmented by pedestrian and bike lanes. The bypass road, on the other hand, will facilitate transshipment ${ }^{5}$ traffic coming from the freight operations at the Three Gorges Dam, which passes through the city center on its way to different parts of the province.

The Bus Rapid Transit system offers commuters a convenient and flexible transport option and complement the scenic city of Yichang which runs parallel to a portion of the Yangtze River. The bus system, along with the bypass road, is a strategic response to accommodate current and future transport demand levels in Yichang. It is poised to further strengthen Yichang's urban transport system and the city's role as a regional logistics hub.

\section{SOLUTIONS}

ADB's Hubei-Yichang Sustainable Urban Transport Project took special care in the preparation and design phases, as the Bus Rapid Transit system along with its other components are to be the backbone of Yichang's sustainable urban transport system. The bus systems corridor runs through the city's main district, Dongshan Avenue, and completely changed the urban terrain, making it greener, safer, and more accessible to all.

Policy dialogue. Yichang's original proposal was focused on road building, not the Bus Rapid Transit system. The city, at first, wanted to build more roads, rehabilitate the major city roads and build more logistics infrastructure. Through policy dialogues with ADB and technical advice from the Institute for Transportation and Development Policy, Yichang agreed to change its plans to implement a bus system.

Comprehensive pre-project analysis. The project first conducted an exhaustive study of the urban transport system in Yichang. It carried out surveys of bus speeds, boarding and alighting time,

5 Pass-dam transshipment is shipping of goods or containers by road or rail to an inland waterway port located upstream or downstream of a dam in order to bypass the ship-lock or ship-lift facility at the dam. 
frequency and occupancy, and number of bus stop transfers. It also gathered data on bus routes and the locations and conditions of bus stop stations. These data were collated and analyzed, and their results were used as inputs to the transport system design. They revealed, among other things, that service reliability needs great improvement on some routes as waiting time varied from 6 minutes to 26 minutes. Bus stops were of very poor quality; they were too narrow, offer insufficient protection against the weather, and are often encroached by taxis. These conditions reflect that in the past, bus operations were not given sufficient priority by the government. The project also considered freight traffic in the city before actual implementation.

Overall, this step in project preparation reflects a holistic approach in urban transport planning. It led to an urban transport system specifically designed to address not just current and future transport demand, but the safety, quality, and reliability concerns surfaced by the prior intensive study.

Extended and customized corridor design. The Bus Rapid Transit corridor will be 23.9 kilometers long, with a route that connects the main residential and business districts with the city's new logistics and industrial park and the high-speed railway station. The corridor, comprised of segregated bus lanes located in the middle of the road, will have 37 fully enclosed bus stations. ${ }^{6}$ Initially, the corridor was supposed to start at the northern end of the Dongshan District and end at the Yichang East railway station in Juecheng, excluding the highly residential Yilling District in the north. However, the pre-project study showed a clear demand for transport from Yilling to the city center and vice versa and so the corridor was extended to the area. This extension to a district that showed high demand promises more financial returns vis-à-vis higher ridership figures. Also, land use development in a highly developing district offers opportunities for a mutually beneficial integration of a smart urban transport system and residential and commercial development in the area.

However, Yilling district's road was not wide enough to accommodate a two-way corridor and a general traffic lane. After careful traffic analysis, the project proposed that the general traffic lane run in one direction with a roundabout section where vehicles can make a $U$-turn to the opposite side. This will allow a segregated two-way bus lane. To further adjust to Yilling's narrow road, continuous bike lanes on both sides will be kept at 1.5 meters wide, and will be reduced to only 1 meter at some critical locations.

Collaboration with stakeholders. In the original Bus Rapid Transit corridor design, resettlement of old residential and commercial buildings owned by a state-owned company on Yemingju Road, the 2.4 kilometer central business district with a hilly and narrow section, was required to install exclusive bus lanes and general traffic lanes for a mixed flow section along the road. The project demonstrated the importance of collaboration with stakeholders, in this case, a state-owned company, to pursue road widening to accommodate the bus system. Through dialogue, the project implementers and the company which owned the properties agreed to resettle the old apartments and buildings to widen the section from its existing 24 meters to 36 meters. This agreement allowed for a consistent design along the central business district section of the Bus Rapid Transit corridor, facilitating urban renewal, in which the bus system plays a leading role.

6 ADB. 2013. Report and Recommendation of the President to the Board of Directors: Proposed Loan to the People's Republic of China for the Hubei-Yichang Sustainable Urban Transport Project. Manila (July). 
Bus stations. The locations of the bus stations were based on where the current bus stops are, the nearest intersections, physical conditions of the roads, transport demand, feedback from local stakeholders, and pedestrian access flows into the corridor. Their details vary, depending on the passenger demand and bus flows in the short and long term, fleet requirements, physical conditions of the roadway, and aesthetic and cost factors. ${ }^{7}$ One station was especially customized, i.e., made shorter than other stations, Deng Jia| IADB Photo Library.

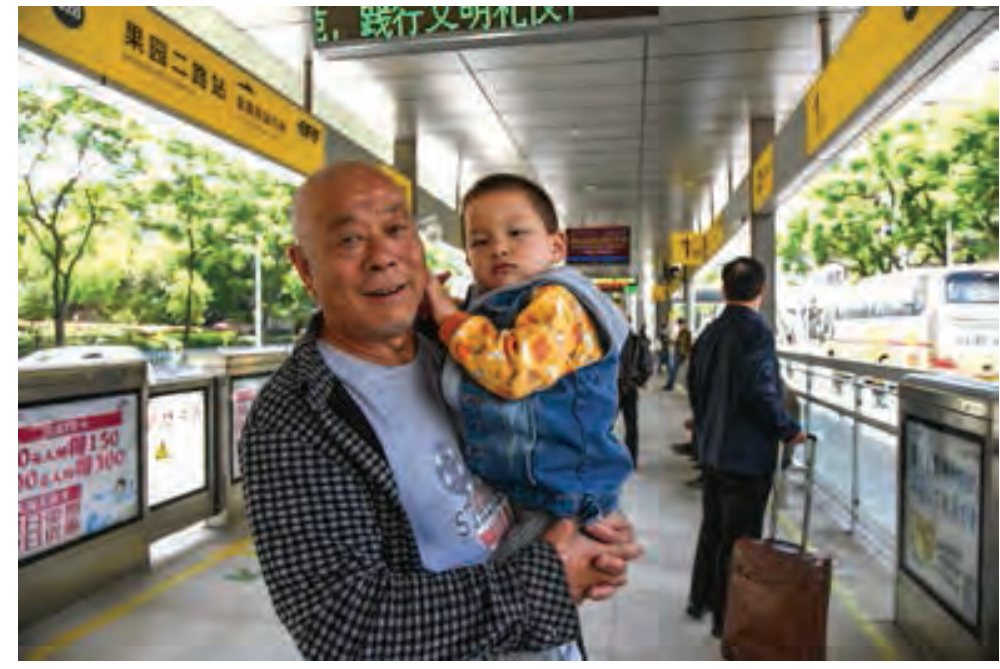

Passengers waiting at the bus terminal. to minimize the need for relocation of affected entities beside it. This tailored design will not hamper access to the buses, nor impair station operation.

Passenger hubs. Two of the factors that discourage commuters from using mass transport in Hubei are the distance between bus stations, and difficulty in transferring from one mode of transport to another. Without the project, there would only be seven bus stops from the north side to the south side of the main city center and only five from south to north, and with no proper nonmotorized transport lanes. Each stop had an average interval of 870 meters. With the bus system, the intervals among the 18 bus stations along the main city center will be about 550 meters, and will have an integrated nonmotorized transport lanes and bike parking facilities so that even cyclists who wish to board buses can park their bikes and access the bus stations. At the same time, the bus system will be connected to provincial bus terminals. This way, provincial bus passengers can easily transfer to the bus system to go around the main city. Another added value of the project is its connection to the East Railway Station, making it more convenient for passengers to transfer from the high-speed train to the bus station and vice versa. The connections among the bus system, provincial buses, and the high-speed rail are housed in one huge passenger terminal plaza, providing a multimodal passenger hub, in addition to the nonmotorized transport lanes that run alongside the bus system's corridor.

Road safety and accessibility features. One of the benefits of constructing a Bus Rapid Transit corridor is the opportunity to improve not only accessibility but also general road safety. The project maximized this opportunity by allotting wide pedestrian paths, especially in the central business district, ensuring connectivity to the bus stations. At the same time, these pathways were connected to safer crossings situated at bus stops, road intersections, and when no bus stops or intersections occur, every 100 meters. Many of these crossings have signals and provided with medians or refuge islands for added safety. The project design also specified improved bicycle facilities along the bus system's corridor to support the accessibility and traffic safety for nonmotorized transport. It

7 ADB. 2013. Project Technical Description. Appendix to the Report and Recommendation of the President to the Board of Directors: Proposed Loan to the People's Republic of China for the Hubei-Yichang Sustainable Urban Transport Project. Manila (July). 


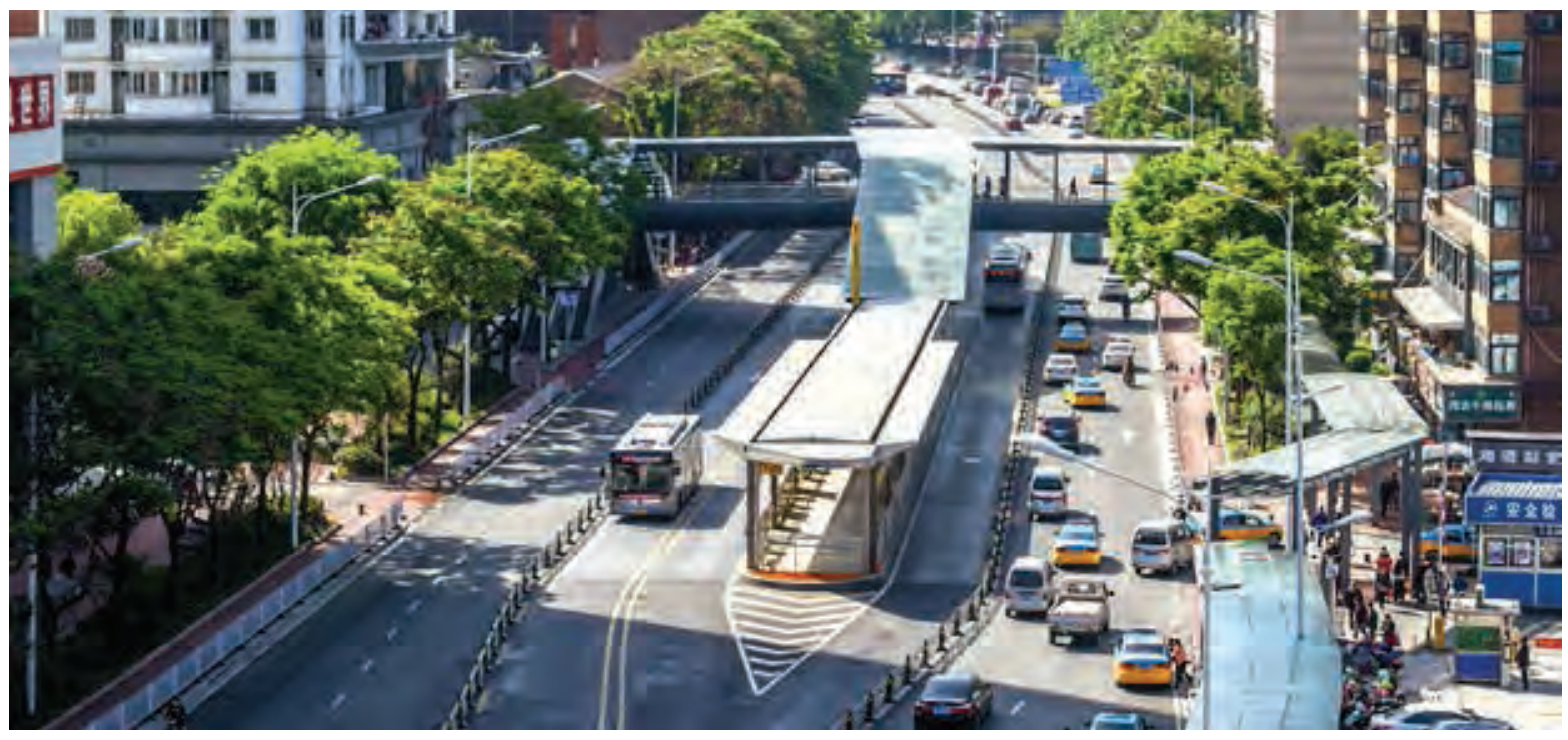

Bus Rapid Transit station in Yichang. Deng Jia | ADB Photo Library.

also emphasized continuous and well-separated bike lanes. ${ }^{8}$ These walkways and bike lanes were arranged to ensure that not only are they connected to the bus stations, but to rail and provincial bus terminals as well.

Road network improvement through the bypass road. The project also features a 23.4 kilometer extension of the Dongshan 4th Road to accommodate through-traffic and freight traffic, including pass-dam transshipment. This component of the project will be constructed in the northern part of Yichang's urban area according to expressway standards to enable heavy traffic to bypass the city center. The proposed design for this road took into consideration several factors: the constraints imposed from existing and proposed land uses surrounding the site, the possible tunnel locations, and land requirements for interchanges.

The bypass road will have three main sections, each designed differently, and runs along a mountainous terrain. This road will have 13 bridges, with spans ranging from 20 meters to 30 meters that will go over rivers, reservoir, and valleys. It will also feature tunnels that will burrow through grade IV 9 classified rocky mountains. The whole length of the bypass road will have space for sidewalks and amenity strips on either side and, in some areas, auxiliary roads and, for tunnels, emergency areas.

\section{RESULTS}

ADB's Hubei-Yichang Sustainable Urban Transport Project will provide large benefits to the urban population of the city. The city center, which will be transformed by the Bus Rapid Transport system, will facilitate residential, commercial, and industrial developments in the northern part of Yichang's urban area, providing economic development and job opportunities for nearby residents. These benefits come along with decreased travel and waiting time, and a convenient, more comfortable, and safer mass transit option.

8 Institute for Transportation and Development Policy. 2013. Yichang BRT Preliminary Design. Final Report. Guanghzou (January).

9 Type of rock suitable for construction of tunnels. 
The project components provide strategic additions to Yichang's Development Plan, which aims to improve and develop nine comprehensive logistics park areas and an urban distribution center in the city. These facilities, which include an airport and inland ports, will further expand the operational capacity of the Three Gorges Logistics Center, and would complete the city's vision of an efficient multimodal logistics network made up of ports, railway, roads, and the airport. The bus system and the bypass road will not

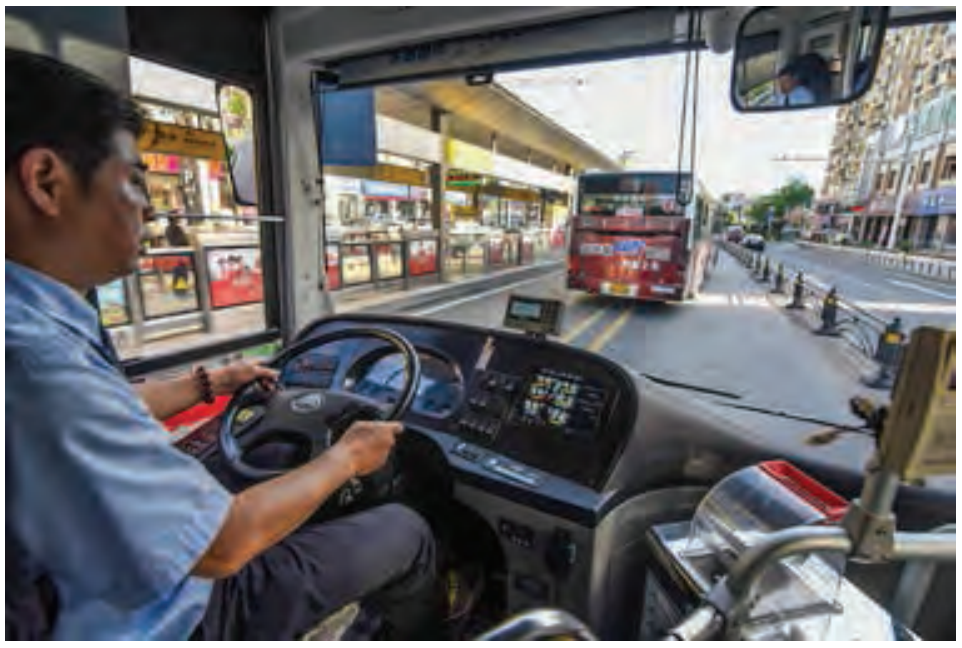

Driver maneuvers at the station. Deng Jia | ADB Photo Library.

only complete this complex transport and logistics architecture, it will also inject sustainability into the whole transport network.

Currently, even if the whole project is yet to be completed, plans are already underway for phase 2 of the Yichang Bus Rapid Transport which will further enhance connectivity within the city by building another corridor that will complement and extend the reach of the first corridor. The planned corridor will run parallel to the first, along Fazhan Dadao, connect to the first bus station in Yunji, and end at Chendong. It will add walkway connections for 12 bus stations and two footbridges that will cross the east railway. It will also integrate a public bicycle system and extend the greenway established in the first project.

The Bus Rapid Transit system and the road construction that went with it are crucial components of the city and the province's goal of making Yichang an effective and efficient center for transport and logistics. It has also catalyzed and set the tone for further expansion of the urban transport network in the city.

\section{LESSONS}

The Hube-Yichang Sustainable Urban Transport Project demonstrates key steps towards achieving an integrated and sustainable transport network. It shows doable actions that could help cities formulate and calibrate transport systems in favor of multimodality, sustainability, and cost effectiveness.

Conduct comprehensive study prior to planning. This project was designed to complement the other transport modes available in Yichang. It addresses choke points, and completes a seamless interchange between and among transport options. It demonstrates how transport options can actively support local trade and development by strategically decongesting city centers and diverting transshipment traffic. A comprehensive study prior to urban transport planning did not only inform project design, but the decision-makers in the city, enabling them to appreciate the real current and future transport needs of their territories. The comprehensive study enabled project implementers to convince decision-makers of the wisdom behind the project design, which was backed up by evidence-based data. 
Consider low-cost yet strategic options. In many cities in Asia, there is a prevailing notion that building more roads and complex transport infrastructure can address congestion in urban roads. The project shows that a Bus Rapid Transport corridor, with a complementary bypass road can be more effective than building an intricate network of flyovers and interchanges in addressing urban congestion, traffic safety issues, and accommodate future growth. It shows value for government money, where savings can be used to extend coverage and maximize benefits of sustainable transport options.

\section{Design for inclusiveness.}

In many Asian countries, residential districts are connected by roads that can only be conveniently accessed by private vehicles. This project linked up a residential district with the bus system's corridor,

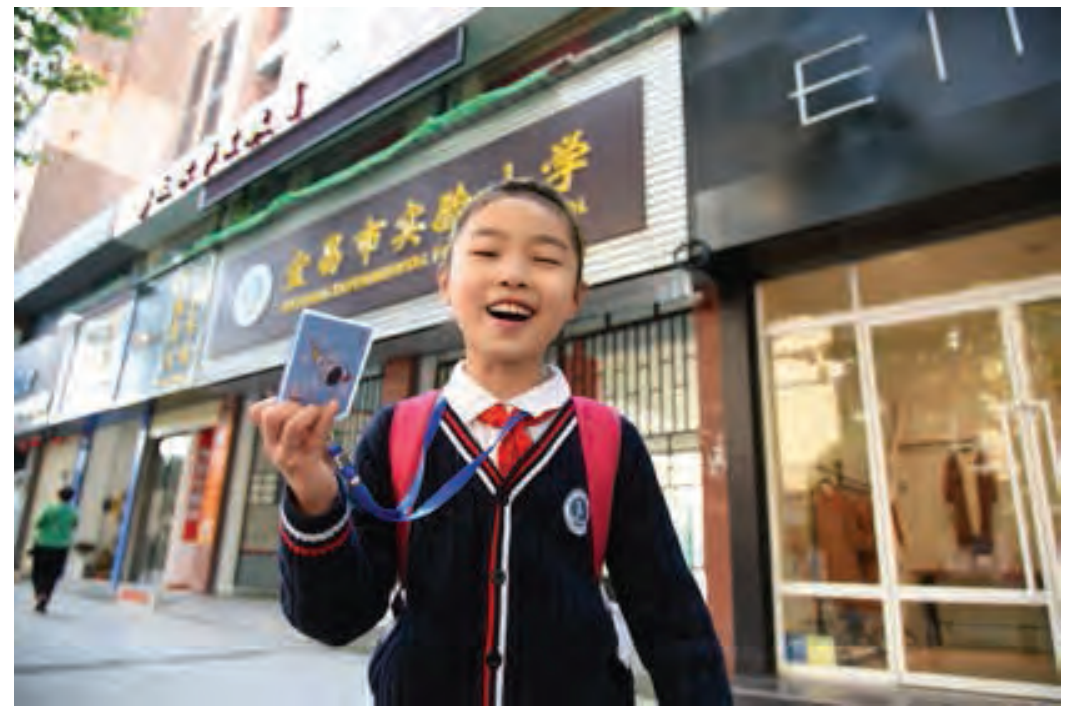

Even school children can access the BRT. Deng Jia | ADB Photo Library. enhancing access to the city center and indirectly to other parts of the region in a more sustainable way, not only through the bus system which connects to ports, provincial terminals and the planned airport, but also through the network of bicycle lanes and walkways. This emphasizes the point, that ultimately, transport should benefit more people. This can be a model for inclusive yet sustainable transport development that can be replicated in the country and across Asia.

Prioritize safety and the environment. Another key learning from this project is the way it has customized sections of the bus system's corridor to prioritize people and the environment. This is shown in the way that care was taken in designing safer crossings for people. It has provided refuge islands and signal systems so that people will have easier and safer road crossings along the bus system's corridor. In addition, it has also adjusted the design of its corridor so that a portion near the river would not need more complex construction which may harm the adjacent river environment. It has also adjusted a station design so that demolition of surrounding facilities will be minimized. 


\section{Keywords:}

Transport, bus rapid transit system, sustainable road transport, roads, bus, pass dam transshipment, Hubei-Yichang Sustainable Urban Transport Project, land transport, People's Republic of China

\section{For further reading:}

- Project web page: http://www.adb.org/projects/45023-002/main

- ADB-Assisted Bus Rapid Transit System Starts Operations in Yichang: https://www.adb.org/ news/adb-assisted-bus-rapid-transit-system-starts-operations-yichang

\section{For further information:}

- Tyrell Duncan, Technical Advisor (Transport), Sustainable Development and Climate Change Department|tduncan@adb.org

- Ki-Joon Kim, Principal Transport Specialist, Sustainable Development and Climate Change Department|kjkim@adb.org

- Dongxiang Li, Lead Regional Cooperation and Integration Specialist, Economic Research and Regional Cooperation Department | dongxiangli@adb.org 

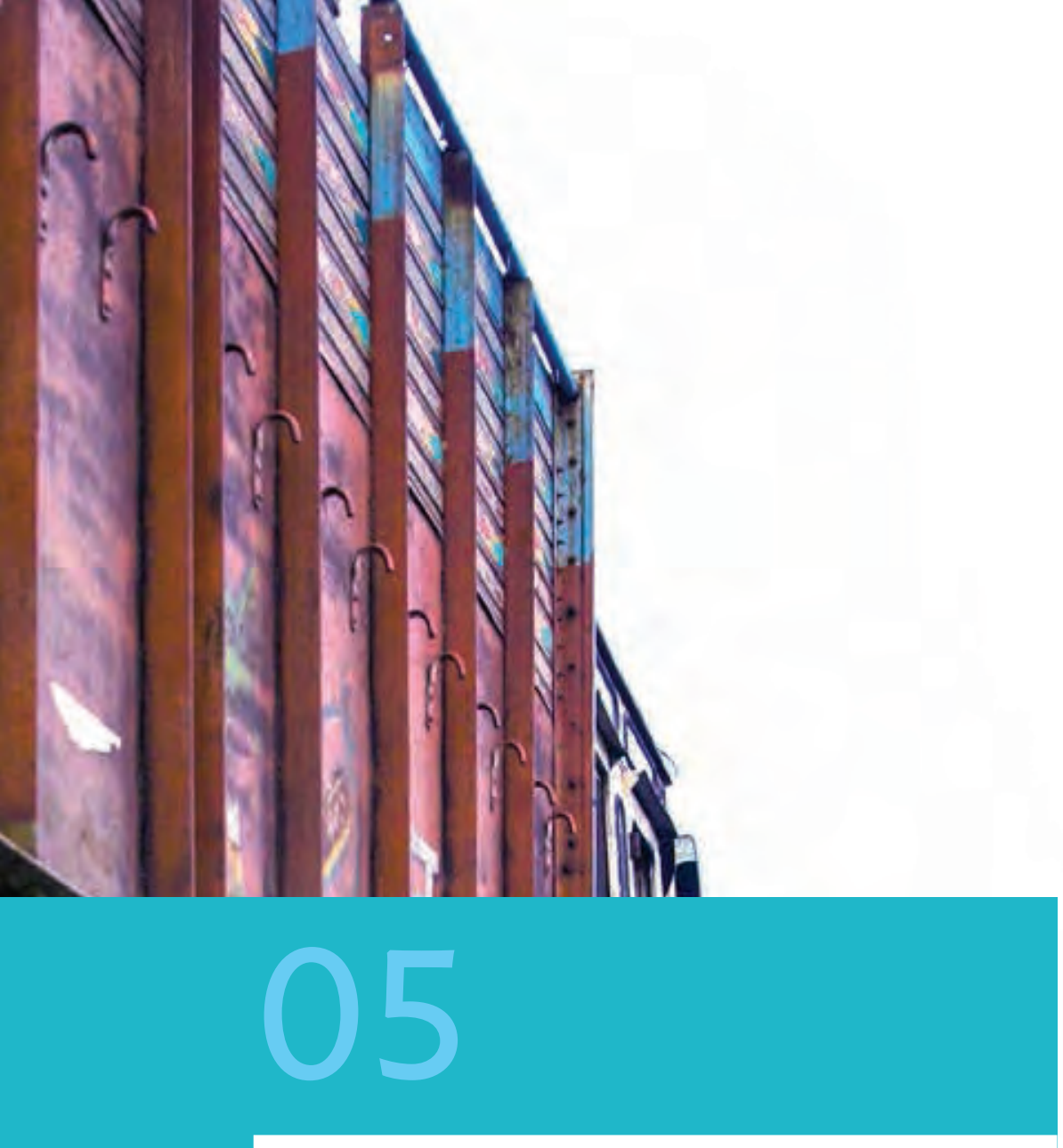

CROSS-COUNTRY CORRIDORS 


\section{CONTEXT}

$\mathrm{N}$

ot only does Nepal's challenging geography limit domestic commerce, it also presents a big roadblock to international

trade. Nepal's semi-isolated economy used to be highly dependent on long and challenging transit routes for imports and exports. Trade facilities and transit logistics that could make freight handling and transfers faster and easier were inadequate and inefficient. Customs clearance procedures and other cross-border inspections were cumbersome and time-consuming. The passage of goods was further delayed by the traffic congestion at border crossings and the poor condition of many access roads. Nepal needed to remove these roadblocks by improving its transport system and trade facilities to better integrate into regional and global markets.

Nepal shares more than half of its total border length with India, its largest trading partner. Much of Nepal's imports and exports, including those to and from its neighbors Bangladesh and Bhutan, pass through India. ${ }^{2}$ Asia is the major source of Nepal's imports, but much of this is entrepot trade moving through Singapore and Hong Kong, China. Besides India, Nepal imports goods from the People's Republic of China (PRC) and the United Arab Emirates. ${ }^{3}$ India is also Nepal's top export destination, though its goods reach as far as Europe and North America.

\section{Project SNAPSHOt}

Nepal: Subregional Transport Facilitation Project

Approval date: NOVEMBER 2004

Amount:

SDR13,643,000 LOAN

(\$2O MILLION EQUIVALENT)

Borrower:

GovernMENT OF NEPAL

Executing agency: Ministry of Physical Planning AND WORKS

Geographical location:

BIRGUNJ, BHAIRAHAWA, AND KAKARBHITTA, NePAL

Transport project: ROAD (NON-URBAN)

Completion date: SEPTEMBER 2010

Within Nepal, about 90\% of all freight are transported through the country's road network. Large amounts of goods pass through five major border crossings with India, either by road or rail. These are Bhairahawa, Birgunj, Birgunj Dryport in Syrsiya, Biratnagar on the southern border, and Kakarbhitta on the eastern border. Birgunj is the country's most important trade border, where 50\% of the country's trade passes through to the capital Kathmandu. There is only one international airport and the nearest seaport in Kolkata, India is 752 kilometers away. To support trade, Nepal relies highly on India's road and rail network and on seaports in Bangladesh or India.

Cargo transported by rail or road is processed in either one of Nepal's three inland clearance depots 4 at Birgunj, Biratnagar, and Bhairahawa. These depots take on part of freight handling and storage from seaports and other border crossings to expedite import-export processing. Aside from India, Nepal also trades with neighbors Bangladesh and Bhutan. ${ }^{5}$

1 About $59 \%$ of Nepal's exports and imports are with India; most of the rest are with countries outside the subregion. Government of Nepal, Ministry of Fianance. 2016. Economic Survey 2016. Kathmandu.

2 Nepal is bordered by India in the west, south, and east and the PRC in the north. It is separated from Bhutan by the Indian state of Sikkim and from Bangladesh by a narrow strip of land in India's West Bengal state.

3 In FY2003-FY2004, 13.2\% of exports went to the PRC; the United Arab Emirates took in 11.3\%. ADB. 2004. Report and Recommendation of the President to the Board of Directors: Proposed Loan to the Kingdom of Nepal for the Subregional Transport Facilitation Project. Manila.

4 Inland clearance depots are equipped with appropriate freight facilities to cut the land transit times considerably by reducing handling time and streamlining cumbersome procedures, resulting in decreased transport costs and lessening dependence on the coastal country's ports and transport industry.

5 Between 1992-1993 and 2000-2003, Nepal's exports to Bangladesh grew annually by $21.4 \%$ and to Bhutan by 56.2\%. ADB. 2004. Report and Recommendation of the President to the Board of Directors: Proposed Loan to the Kingdom of Nepal: Subregional Transport Facilitation Project. Manila. 


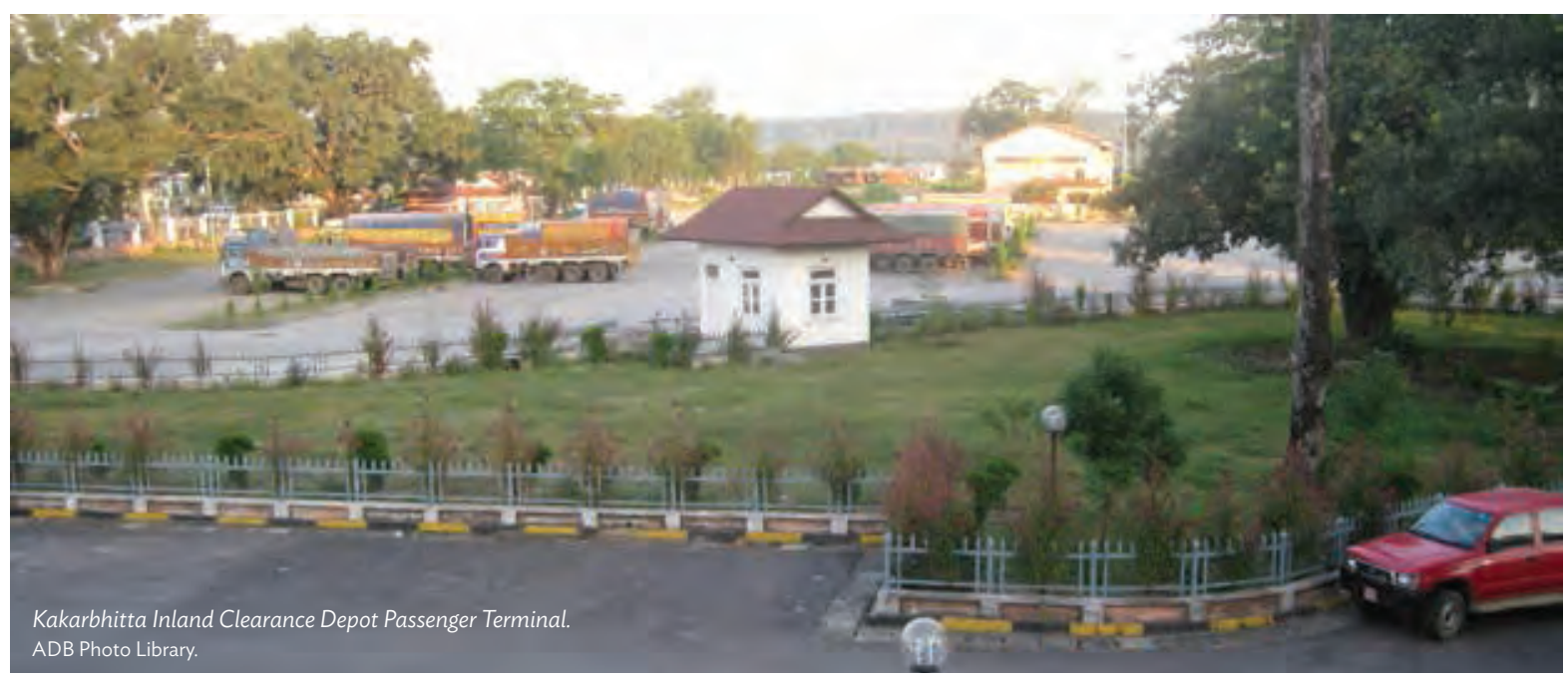

In 2004, the Asian Development Bank (ADB) approved the Subregional Transport Facilitation Project to assist the Government of Nepal in integrating the country's economy into the South Asian and global markets. The project was an integral part of the ADB-supported SASEC Program that promotes trade, connectivity, and cooperation among countries in the South Asia subregion. ${ }^{6}$

The project was completed in September 2010.

\section{SOLUTIONS}

ADB's Subregional Transport Facilitation Project removed roadblocks to Nepal's trade by updating the customs administration software, constructing a new inland clearance depot, and rehabilitating border access roads.

Customs administration software upgrade. The project updated the Automated System for Customs Data (ASYCUDA) software that speeds up cargo clearance and simplifies customs documentation and procedures. Developed by the United Nations Conference on Trade and Development, ASYCUDA manages huge amounts of customs data and performs various customsrelated functions. It is a computerized customs management system, which covers most foreign trade procedures. The system handles manifests and customs declarations, accounting procedures, and transit and suspense procedures. ASYCUDA is used in over 90 countries, territories, and regions. ${ }^{7}$

An upgraded version of the software, ASYCUDA++, was installed and customized for Nepal, which includes considering customs procedures, rules, and regulation. ASYCUDA++ introduces a new Selectivity Controls Module, which is an essential element of risk analysis for a specific customs

6 The SASEC Program promotes trade, connectivity, and cooperation among countries in the South Asia subregion The Subregional Transport Facilitation Project was designed to help decongest three regional transport corridors that involve Nepal. The first begins in Kathmandu going south to the Birgunj-Raxaul border and further down south to the Kolkata and Haldia ports in India. The second also begins in Kathmandu going to Kakarbhitta and the Fulbari-Banglabandha border and further going south to the Dhaka, Mongla, and Chittagong ports in Bangladesh. The third starts in Kathmandu going south to the Bhairahawa-Sunauli border and further to Lucknow, India. These choke points were system-wide impediments to cross-border cargo movement within the subregion. See SASEC Programs: http://www.adb.org/countries/subregional-programs/sasec

7 For more information on ASYCUDA, see http://www.asycuda.org/ 
office. The module uses customs declaration data and other information to identify goods or transactions of particular interest to customs, such as those that may present risks to national objectives, including risks to the collection of duties or taxes or to the enforcement of customs controls. The module was installed in five key customs offices, instead of the originally planned 10 customs offices. The steering committee at the Department of Customs decided to implement the Selectivity Control Module only in those customs offices where adequate support was available, including intelligence arrangements. A risk management structure was adopted in 2009 with the appointment of a risk management team in the Department of Customs and in the customs offices at the Tribhuvan International Airport, Birgunj Customs, and Birgunj Inland Clearance Depot. The Customs Broker Module, which facilitates direct trade inputs, was also installed in three customs offices.

Besides the ASYCUDA upgrade, the project also installed a wide area network (WAN) and related telecommunications and computer equipment. Network equipment and communication software for WAN were procured, installed, and operationalized at all 10 customs offices. This paved the way for the Department of Customs to consolidate data from all customs offices into comprehensive and accurate trade and revenue statistics.

Eight separate training sessions on ASYCUDA++ were conducted for the Department of Customs staff. Training on the use of the Selectivity Controls Module was provided to the national project team at the Department of Customs and to the customs staff in each office where the module was deployed. Training for the Customs Broker Module was provided to 10 separate groups, including trainers-to-be, customs staff, information technology experts, and brokers and traders from different border customs areas. Training on WAN operation and troubleshooting for the technology staff of each customs office was also conducted.

Some difficulties arose in contract administration between the Department of Customs and the United Nations Conference on Trade and Development (UNCTAD), especially since the contract did not have clear provisions on the role and responsibilities of the Department of Customs. While the Department of Customs carried out the activities related to ASYCUDA++ and WAN, the contract was drawn up and signed by UNCTAD and the Department of Roads, which supervised the overall project implementation and had considerable experience with ADB-financed projects. The Department of Roads is under the Ministry of Physical Planning and Works, which is the executing agency for the project.

New inland clearance depot. The project financed the construction of a new inland clearance depot at Kakarbhitta on the eastern border of $\mathrm{Nepal}$, with all necessary facilities. The depot is a 7.5-hectare complex with a three-storey main building, two goods inspection sheds, immigration offices, a warehouse, a litigation shed, passenger terminal, staff quarters, and an 18,800-square meter container platform. The design standards of these facilities comply with the requirements of Nepal's National Building Code.

Political unrest in the eastern Terai region and a sudden rise in the cost of construction materials caused some delay. The contractor became unwilling to continue construction works because of the price increase since price adjustments were not covered by the civil works contract. ADB later approved the introduction of a price adjustment clause in the contract. Minor variations of about $13.5 \%$ of the contract amount were incurred for additional drainage works, landscaping, and construction of false ceilings in staff quarters. 
The Kakarbhitta Inland Clearance Depot was built on public land, thereby avoiding any issue on land acquisition. The operation of the depot was expected to be handed over to a private terminal management company at least 3 months before completion. With the lack of interested companies, management of the depot was handed over to the Nepal Intermodal Transport Development Board. ${ }^{8}$ Construction began in November 2007 and was completed in June 2010.

\section{Better road access to inland clearance}

depots. About 41 kilometers of roads were constructed or rehabilitated to

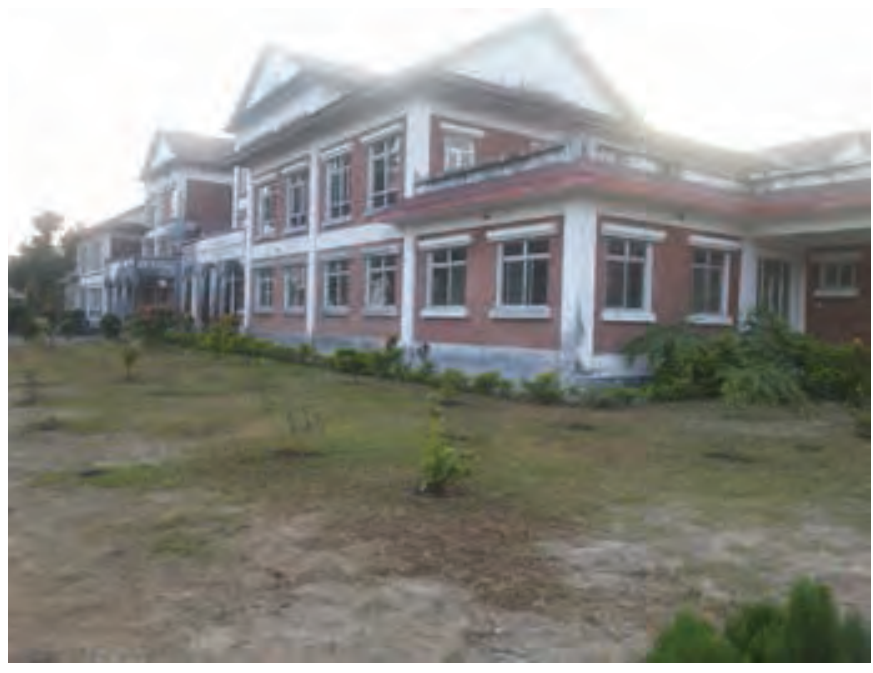

Kakarbhitta Inland Clearance Depot Passenger Terminal Administration building. ADB Photo Library. unclog traffic in Birgunj and Bhairahawa: the 12.4-kilometer two-lane Birgunj access road that connects the Birgunj Inland Clearance Depot to Tribhuvan Highway and the 29-kilometer-long Bhairahawa access road that connects the Bhairahawa Inland Clearance Depot to Bhumahi on the East-West Highway leading to Kathmandu and other parts of Nepal.

The access roads have a 7.5-meter carriageway. Minor rehabilitation works included widening of a 600-meter road near Birgunj Inland Clearance Depot and a 1.48-kilometer road in Jeetpur township. The national highway design standard was adopted in the design of all roads sections, using low-cost double bituminous surface treatment. Rehabilitation of a part of the Bhairahawa access road was delayed by 6 months due to the late implementation of resettlement activities.

\section{RESULTS}

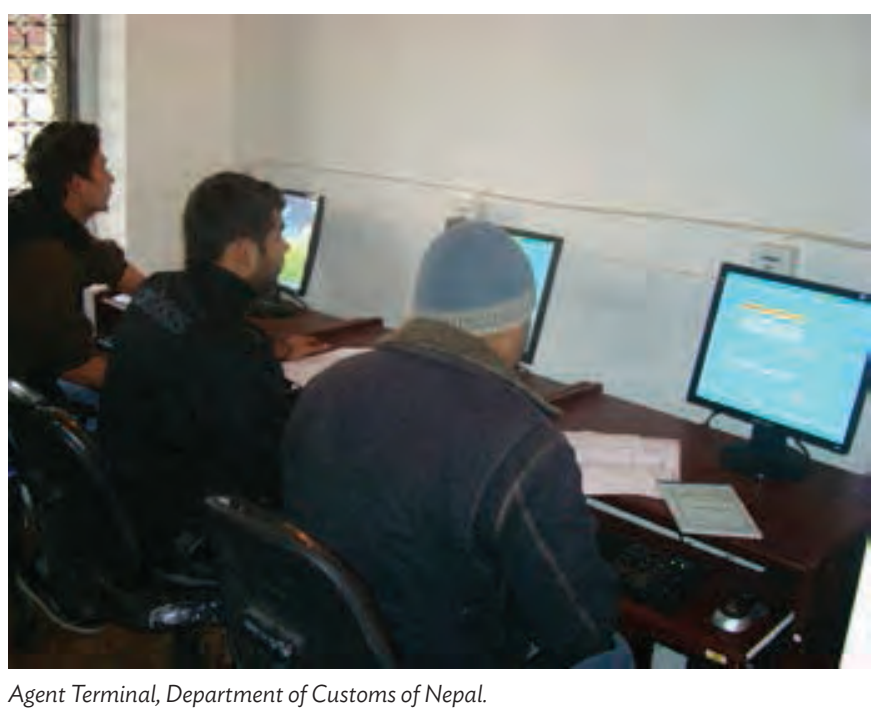
Agent Terminal, Department of Customs of Nepal.
ADB Photo Library.

Overall, ADB's Subregional Transport Facilitation Project has allowed for the easier, faster, and smoother flow of tradeable goods into and out of Nepal. The cost of capital for cargo is reduced by $12 \%$ annually. Through the project, Nepal is now better connected to the subregional economy.

8 Invitation for bids was published twice, but did not receive any response from potential bidders. The June 2009 Midterm Review Mission observed that it may not be possible for the private terminal management company to recover an amount equivalent to the debt service payment related to the construction costs of the Kakarbhitta Inland Clearance Depot because trade volumes at the eastern gateway are lower than expected. ADB. 2004. Project Completion Report: Nepal: Subregional Transport Facilitation Project. Manila. 
Faster and more efficient cross-border processes. The installation of ASYCUDA++ modules and WAN, along with the adequate training of the Department of Customs staff, has substantially increased the efficiency in cargo clearance and management. ASYCUDA++ is operational in 10 customs offices covering over $90 \%$ of the trade between Nepal and India. The system is the backbone of revenue processing and generation after the project-supported upgrades, including the broker and selectivity modules. The Department of Customs fully owns the system and has institutionalized it by providing the necessary human and financial resources. The Selectivity Controls and Customs Broker modules have reduced paper processing and inspection times, and cargo dwell times. Average cargo clearance time in major customs offices has been reduced from about 3.5 hours to about 40 minutes.

More accessible eastern gateway. The construction of the Kakarbhitta Inland Clearance Depot filled in the crucial gap in the development of cross-border facilities in Nepal, particularly in the eastern gateway, which accounts for about $13 \%$ of the country's trade with Bangladesh, Bhutan, and India. The new depot offers more customs facilities for both passengers and freight, and facilities for the immigration department. The new facilities have shortened the time needed to inspect passengers' papers and luggage. Risks of theft and damage to cargo have been reduced. The ASYCUDA++ modules and WAN were also installed in the Kakarbhitta Inland Clearance Depot, which made customs and cross-border procedures faster and more efficient.

Lower cost of transporting exports and imports. With better pavements on the newly constructed or rehabilitated access roads, travel time and vehicle operating costs have been substantially reduced, thereby lowering the cost of transporting export and import goods. Average road user cost per vehicle reduced by $23.1 \%$ on the Bhairahawa access road and by $20.5 \%$ on the Birgunj access road. The road upgrade at Bhairahawa has shortened the east-bound route to the East-West Highway from 41 kilometers to 29 kilometers, while that at Birgunj has shortened the existing route by 0.88 kilometers and significantly reduced traffic congestion. The two access roads are now part of the strategic highways in the country. The toll for these roads will contribute to funds for routine and recurrent road maintenance.

\section{LESSONS}

ADB's Subregional Transport Facilitation Project is more than just a transport project in that its aim is to improve trade and transport logistics performance to remove roadblocks to international trade. As such, it requires coordination among all relevant government agencies and stakeholders.

\section{Involve all stakeholders and relevant government agencies in project preparations.}

The Department of Customs felt that it could have been more effective in the UNCTAD contract implementation if it were a party to the contract. The department's involvement in contract preparation could have resulted in a more detailed terms of reference to meet the specific needs of the department, particularly regarding the training of customs staff on ASYCUDA++ and WAN.

This lesson proved useful in ADB's Subregional Transport Enhancement Project, which is further upgrading ASYCUDA++ to the latest version, ASYCUDA World. Under this project, the contract was signed between UNCTAD and the Department of Customs as the implementing agency. 


\section{Keywords:}

Rural road, trade and transport facilitation, inland clearance depot, customs, Subregional Transport Facilitation Project, land transport, Nepal

\section{For further reading:}

- Project web page: http://www.adb.org/projects/37027-013/main

- Validation of Project Completion Report: http://www.adb.org/documents/nepal-subregionaltransport-facilitation-project

\section{For further information:}

- Bhupendra Bhatt, Procurement Officer, South Asia Department | bbhatt@adb.org

- Kenichi Yokoyama, Country Director (Nepal), South Asia Department | kyokoyama@adb.org

- Tyrrell Duncan, Technical Advisor (Transport), Sector Advisory Service Cluster, Sustainable Development and Climate Change Department | tduncan@adb.org

- Ki-Joon Kim, Principal Transport Specialist, Sustainable Development and Climate Change Department|kjkim@adb.org

- Dongxiang Li, Lead Regional Cooperation and Integration Specialist, Economic Research and Regional Cooperation Department | dongxiangli@adb.org 


\section{CONTEXT}

\section{he road that connects Almaty in Kazakhstan and Bishkek in the Kyrgyz Republic was seriously degraded, hampering trade and tourism between the two cities. Almaty and Bishkek are} separated by fewer than $250 \mathrm{~km}$ and have strong commercial, cultural, and historical ties. Both cities have the highest per capita income within their respective countries and are among the largest economies in Central Asia. Completed 20-25 years ago, the Almaty-Bishkek Road required rehabilitation to prevent further deterioration.

Almaty is the commercial capital of Kazakhstan. With a population of more than 1.5 million people, the city is a destination for migrant labor from neighboring countries and a stopover for many travelers. It is a regional gateway, serving as a distribution center for goods and as a hub for international organizations and companies. Bishkek, with a population nearly close to 1 million, is the capital of the Kyrgyz Republic. The city sits near the border with Kazakhstan and serves as the country's primary trade center, where imports and exports are consolidated and distributed.

In 2000, ADB approved the Almaty-Bishkek Regional Road Rehabilitation Project. The project aimed to improve road transport infrastructure, safety, and efficiency between the two economic centers and bring about development across Central Asia through regional cooperation.

The Almaty-Bishkek Road is the crucial link of an economic corridor being developed under ADB's Central Asia Regional Economic Cooperation (CAREC) ${ }^{1}$ Program, which links Europe to East Asia and traverses from the border of the Russian Federation to the PRC. ${ }^{2}$ It also links two north-south roads within the region, Almaty-Astana and Bishkek-Osh. ${ }^{3}$ It is part of the East-West Corridor passing through the PRC and several commercial centers in the region including Almaty, Ashgabat, Bishkek, Samarkand, Shymkent, and Tashkent.

The project was completed in 2007.

\section{PROJECT SNAPSHOT}

Kazakhstan and the Kyrgyz Republic: Almaty-Bishkek Regional Road Rehabilitation Project

Approval date: OCTOBER 2000

Amounts: \$52 MILLION LOAN (KAZAKHSTAN); \$5 MILLION LOAN (Kyrgyz Republic)

Cofinancing: \$25 MILLION - EUROPEAN BANK FOR RECONSTRUCTION AND DEVELOPMENT (LOAN)

$\$ 400,000$ - EUROPEAN UNION (GRANT)

Borrowers:

GOVERNMENT OF KAZAKHSTAN AND GOVERNMENT OF THE KYRGYZ Republic

Executing agency: MINISTRIES OF TRANSPORT AND COMMUNICATIONS, KAZAKHSTAN and the Kyrgyz Republic

Geographical location:

Between Almaty in Kazakhstan AND BISHKEK IN THE KYRGYZ REPUBLIC

Transport project: ROAD (NON-URBAN)

Completion date: August 2007 (KAZAKHSTAN);

DeCEMBeR 2007 (KYRGYZ RepUbLIC)

1 The CAREC, Program is a partnership of 10 countries (Afghanistan, Azerbaijan, the PRC, Kazakhstan, the Kyrgyz Republic, Mongolia, Pakistan, Tajikistan, Turkmenistan, and Uzbekistan), and supported by six multilateral institutions. CAREC helps Central Asia and its neighbors realize their significant potential by promoting regional cooperation in four priority areas: transport, trade facilitation, energy, and trade policy. CAREC Subregional Programs: http://www.adb.org/countries/subregional-programs/carec

2 CAREC Economic Corridors: http://www.carecprogram.org/index.php?page=corridor-1

3 ADB. 2009. Project Performance Evaluation Report: Almaty-Bishkek Regional Road Rehabilitation Project in Kazakhstan and the Kyrgyz Republic. Manila. https://www.adb.org/documents/kazakhstan-and-kyrgyz-republic-almaty-bishkek-regional-road-rehabilitationproject 


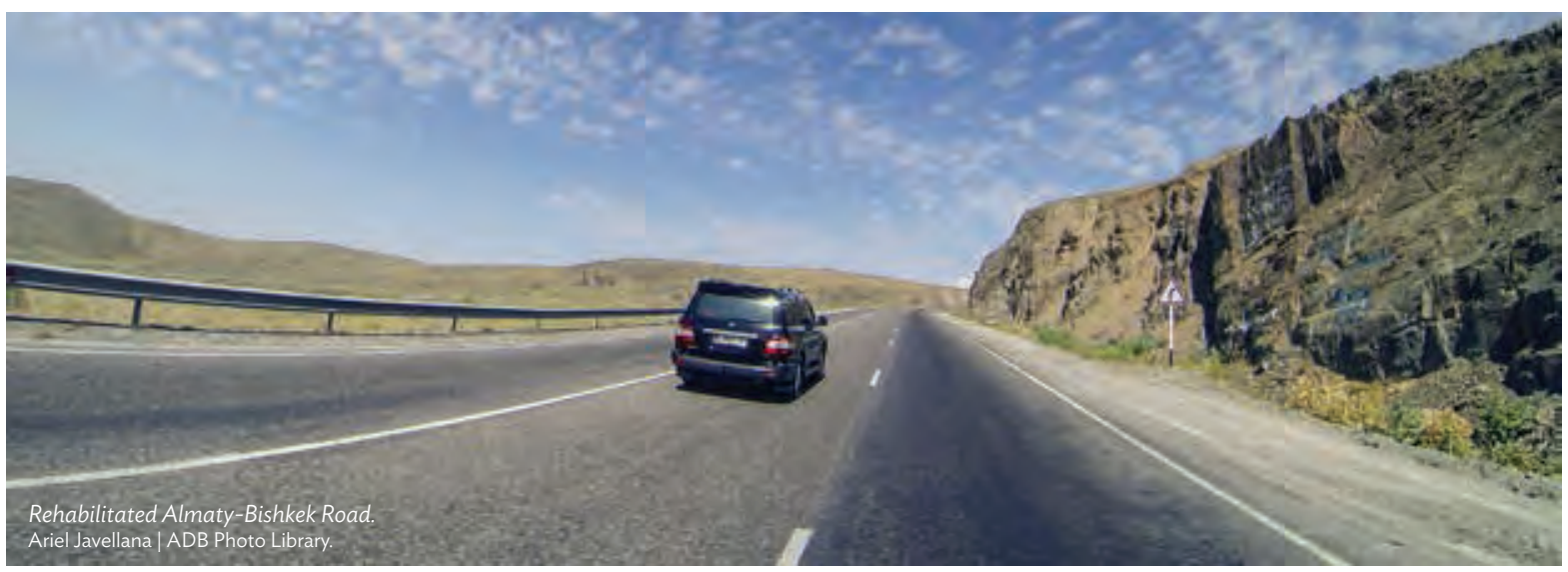

\section{SOLUTIONS}

ADB's Almaty-Bishkek Regional Road Rehabilitation Project enhanced cross-city connections between Almaty and Bishkek to support regional growth in Central Asia.

Cross-border agreement. The project's defining feature is a cross-border agreement between the Government of Kazakhstan and the Government of the Kyrgyz Republic that would regulate and ease the movement of people, goods, and vehicles across the common border. The agreement was set as a precondition for loan effectiveness, with the understanding that, unless effective border crossing procedures were instituted and implemented, the investment component of the project might not bring the intended project benefits to road users and the economies of the countries.

Both governments required the agreement and loans to be ratified through their parliaments. To resolve differences in the legal, judiciary, and regulatory systems of the two countries, a series of discussions and bilateral talks on the agreement were held before it was presented to the countries' parliaments, resulting in significant delay in loan effectiveness. The governments finally signed and ratified the agreement in 2002. The initiatives under the agreement made border crossing procedures much easier and more transparent. Vehicle weights and dimensions and customs documentation were harmonized.

Cross-country road rehabilitation. The project rehabilitated about $225.7 \mathrm{~km}$ of road infrastructure: 206.4 km in Kazakhstan and $19.3 \mathrm{~km}$ in the Kyrgyz Republic. The original plan was to rehabilitate about 245 km of the Almaty-Bishkek road, with about 204 km in Kazakhstan and 41 km in the Kyrgyz Republic. ${ }^{4}$

While rehabilitation of the entire length of the road in Kazakhstan was completed as planned, the length of the rehabilitated road in the Kyrgyz Republic was reduced from $40.8 \mathrm{~km}$ to $19.2 \mathrm{~km}$. Funds had to be reallocated to rehabilitate major bridges and main road sections whose pavements were in very poor condition. Further degradation of road pavements and bridges occurred during the lapse of about 4-5 years between the road assessment and the start of construction, which eventually led to subsequent changes in project scope and cost overruns.

4 ADB. 2000. Report and Recommendation of the President to the Board of Directors: Proposed Loans and Grant to the Republic of Kazakhstan and the Kyrgyz Republic for the Almaty-Bishkek Regional Road Rehabilitation Project. Manila. http://www.adb.org/projects/ documents/almaty-bishkek-regional-road-rehabilitation-project-rrp 


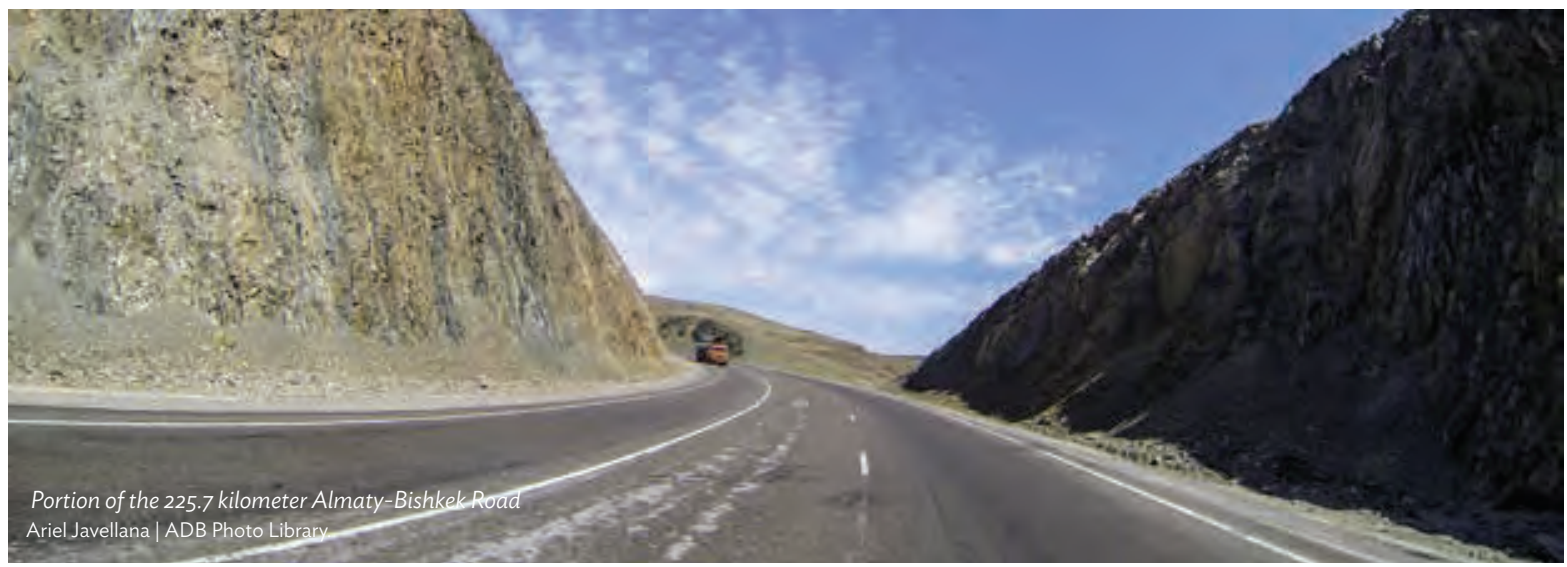

The rehabilitation of the Almaty-Bishkek Road followed varying road design standards for different sections depending on traffic level forecast, condition of existing road and structures, and selected design speeds. Hazardous and substandard sections, where trucks and buses travel very slowly, were corrected or eliminated. Among the most dangerous was the Kurdai mountain pass, whose steep gradients and sharp curves often cause the overturning of vehicles going downhill. The pass was often impassable during winter when the road becomes slippery because of snow. The project realigned and substantially improved the mountain pass, with gentler gradients, softer curvatures, and dedicated climbing lanes for heavy commercial vehicles.

Delays in road construction, apart from the 2 years it took for the cross-border agreement to be effective, were mainly due to the inexperience of the ministries of transport and communications of both countries in ADB procedures. Both governments and their ministries were relatively new to internationally funded projects, and had little experience in ADB-financed projects.

Improved road maintenance. To avoid further road deterioration, the project introduced a road maintenance system and improved the coordination and management of road safety. Road maintenance equipment for Kazakhstan was procured, including multifunctional trucks, crack repair equipment, road marking machines, road rollers, and radio communication systems. The project did not cover any similar equipment for the Kyrgyz Republic. While the project aimed to introduce a system for road maintenance by contract and establish an equipment pool in Kazakhstan, the rapid development of the private sector during project implementation increased opportunities in the domestic market for direct sourcing such equipment and services.

Both governments substantially increased financing for road maintenance to preserve road assets and introduced road maintenance by contract through outsourcing periodic maintenance activities to the private sector. They are also willing to introduce international best practices in managing the road assets. These include supervision of maintenance activities by private sector consultants, implementation of pavement management and road asset management systems, implementation of performance-based road maintenance contracts, and international tendering procedures.

Customs facilities upgrade. The project also improved customs facilities at the Akzhol-Chu border. An automated customs clearance system was introduced to support customs operations, especially given the rapid increase in traffic volume throughout project implementation. The equipment required for system and related training for the customs officials was financed under the European Union's Transport Corridor Europe Caucasus Asia Program grant. Six customs personnel 


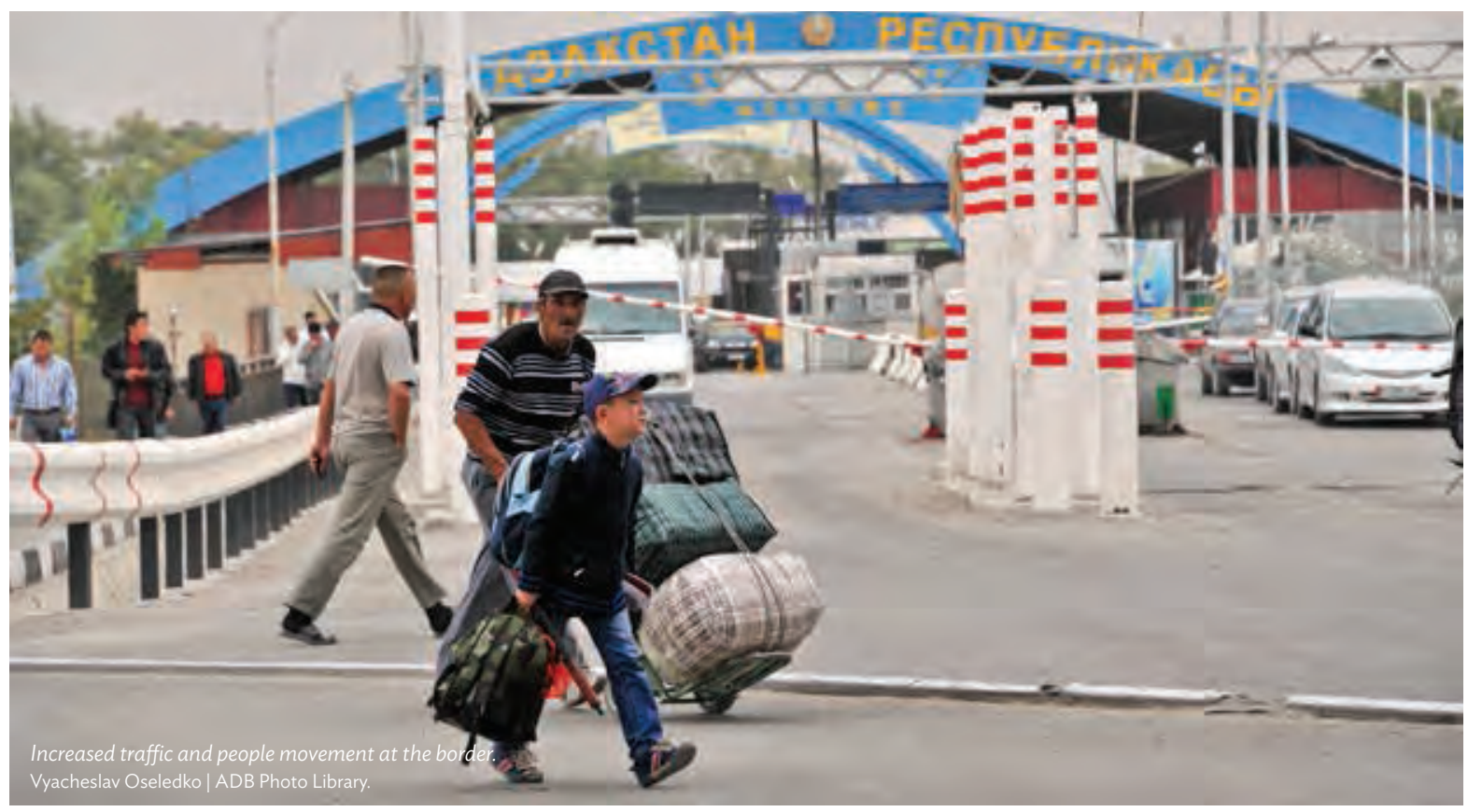

were trained on the new system. Computerized cargo registration was also introduced to improve transparency and deter unauthorized payments at the border crossing. Other customs control equipment such as metal detectors, $x$-ray equipment, computers, and electronic tagging equipment were installed on both the Kazakhstan and the Kyrgyz Republic sides.

\section{RESULTS}

As part of an economic corridor under the CAREC Program, the Almaty-Bishkek Road is expected to spur economic growth in the Central Asia region.

Increase in cross-country road traffic. By 2011, the volume of traffic on the road had risen by $25 \%$ over the 1998 level. ${ }^{5}$ Better road alignment and improved pavements have allowed the average travel speed to increase from $40 \mathrm{~km}$ per hour to $80 \mathrm{~km}$ per hour, reducing travel time and vehicle operating costs. Lower freight rates and public transport fares are also expected, which can provide more convenient and faster access to market for the people in Almaty and Bishkek as well as the rural communities in between.

However, road accidents have increased due to the increased travel speeds and vehicle overtaking opportunities, with the number of fatalities increasing threefold in $2006 .{ }^{6}$ Although the project road was designed and rehabilitated to international road safety standards, the problem appears to stem from driver behavior and cultural aspects. Moreover, enforcement of traffic rules has been lacking in Central Asian countries and, for most drivers, it is relatively easy to obtain a driving license without going through a proper driver education program.

5 CAREC project page: http://www.carecprogram.org/index.php?page=almaty-bishkek-regional-road-rehabilitation-project-kyrgyzrepublic-component

6 ADB. 2007. Project Completion Report: Almaty-Bishkek Regional Road Rehabilitation Project in Kazakhstan and Kyrgyz Republic. Manila. http://www.adb.org/projects/documents/almaty-bishkek-regional-road-rehabilitation-project 
Both governments are currently undertaking initiatives to improve road safety. Kazakhstan has passed several road legislations, including the most recent Law on Road Traffic in 2014. The Kyrgyz Republic has established a National Road Safety Council to assist in preparing safety action plans, improving collection and processing of road accident data, and coordinating and implementing road safety initiatives.

Increase in trade and commerce between Almaty and Bishkek. Trade in goods between Kazakhstan and the Kyrgyz Republic via the Akzhol-Chu border crossing increased by an average annual rate of $38 \%$ from 2000 to 2007 . New livelihoods emerged in the form of retail shops, taxis, car washes, roadside cafes, hair salons, and other enterprises. Between 1998 and 2011, exports from the Kyrgyz Republic to Kazakhstan had increased by $160 \%$ (footnote 5). During project implementation, some 3,000 jobs were made available for the local population directly on the road rehabilitation activities. About $50 \%$ of these workers were unskilled and $10 \%$ were women. Commercial outlets along the road have also mushroomed.

Kazakhstan is one of the major trading partners of the Kyrgyz Republic. Trade between the two countries has increased by $4-5$ times since the beginning of the project, mainly because the rehabilitated road provided a stronger link between two major markets in Central Asia, one on the outskirts of Bishkek and the other near Almaty. As most of the goods are transported along the project road between these two markets, the project has also positively contributed to those whose employment and livelihood rely on these markets.

Further expansion of the border facilities is planned, as well as further streamlining of border crossing procedures to allow for speedy and smooth movement of vehicles, passengers, and goods. The two governments have been discussing the introduction of a joint customs inspection and clearance at the Akzhol-Chu border. They are also planning to enforce vehicle weight and dimension controls through inland control points and advance vehicles clearance procedures. Draft documents are being considered by the parliaments of the two countries.

\section{LESSONS}

ADB's Almaty-Bishkek Regional Road Rehabilitation Project was a very challenging, large-scale, twocountry, cross-border road project. Such transborder infrastructure projects often involve broad and complex issues that can be difficult to resolve and requires adequate time.

Ensure commitment of borrower countries. The project was among ADB's first interventions in the transport sector in the two countries, and both were at the early stages of transition to market economies. The requirement of the cross-border agreement as a precondition for loan effectiveness, while it caused delay, ensured the commitment of the Government of Kazakhstan and the Government of the Kyrgyz Republic in seeing through the project's implementation. The agreement was instrumental in making the two countries work together. Through the agreement, the governments worked on not only making border crossing procedures easier, but also on road maintenance and road safety initiatives.

Prioritize orientation and training of executing agencies. The capacity of the ministries of transport and communications of both countries as executing agencies was limited as was their understanding of international bidding, contracting practices, and ADB procedures. The lack 
of careful consideration of the limited capacity and inexperience of the executing agencies in managing ADB projects impeded the transition from project planning to implementation. During the significant amount of time that had elapsed until before project implementation, the AlmatyBishkek Road sustained further deterioration, requiring more improvement works. Road redesign with a reduced project scope resulted in further delays and additional costs. Such limitation of the executing agency should be considered in project preparation and planning.

\section{Keywords:}

road transport, cross-border customs facilities, rural road, maintenance, economic corridor, AlmatyBishkek Regional Road Rehabilitation Project, land transport, Kazakhstan, Kyrgyz Republic

\section{For further reading:}

- Project web page: Kazakhstan: Almaty-Bishkek Regional Road Rehabilitation Project http://www.adb.org/projects/29568-013/main

- Project web page: Kyrgyz Republic: Almaty-Bishkek Regional Road Rehabilitation Project http://www.adb.org/projects/32463-013/main

- Operationalizing Economic Corridors in Central Asia: A Case Study of the Almaty-Bishkek Corridor http://www.adb.org/publications/operationalizing-economic-corridors-central-asiacase-study-almaty-bishkek-corridor

- CAREC Program web page: Almaty-Bishkek Regional Road Rehabilitation Project http://www. carecprogram.org/index.php?page=almaty-bishkek-regional-road-rehabilitation-projectkyrgyz-republic-component

\section{For further information:}

- Prianka Seneviratne, Principal Portfolio Management Specialist, Central and West Asia Department | pseneviratne@adb.org

- Tyrrell Duncan, Technical Advisor (Transport), Sustainable Development and Climate Change Department|tduncan@adb.org

- Ki-Joon Kim, Principal Transport Specialist, Sustainable Development and Climate Change Department|kjkim@adb.org

- Dongxiang Li, Lead Regional Cooperation and Integration Specialist, Economic Research and Regional Cooperation Department | dongxiangli@adb.org 
1 Hew

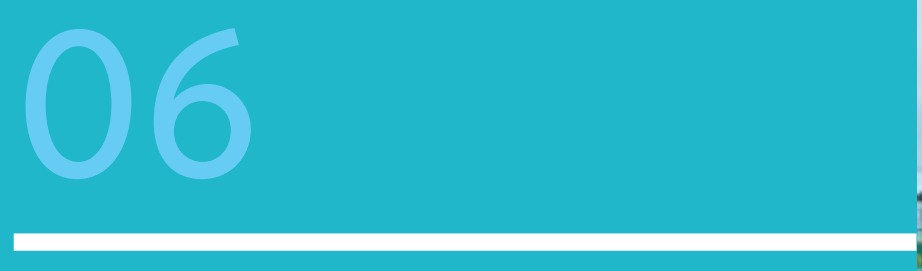

IN-COUNTRY

EXPRESSWAYS
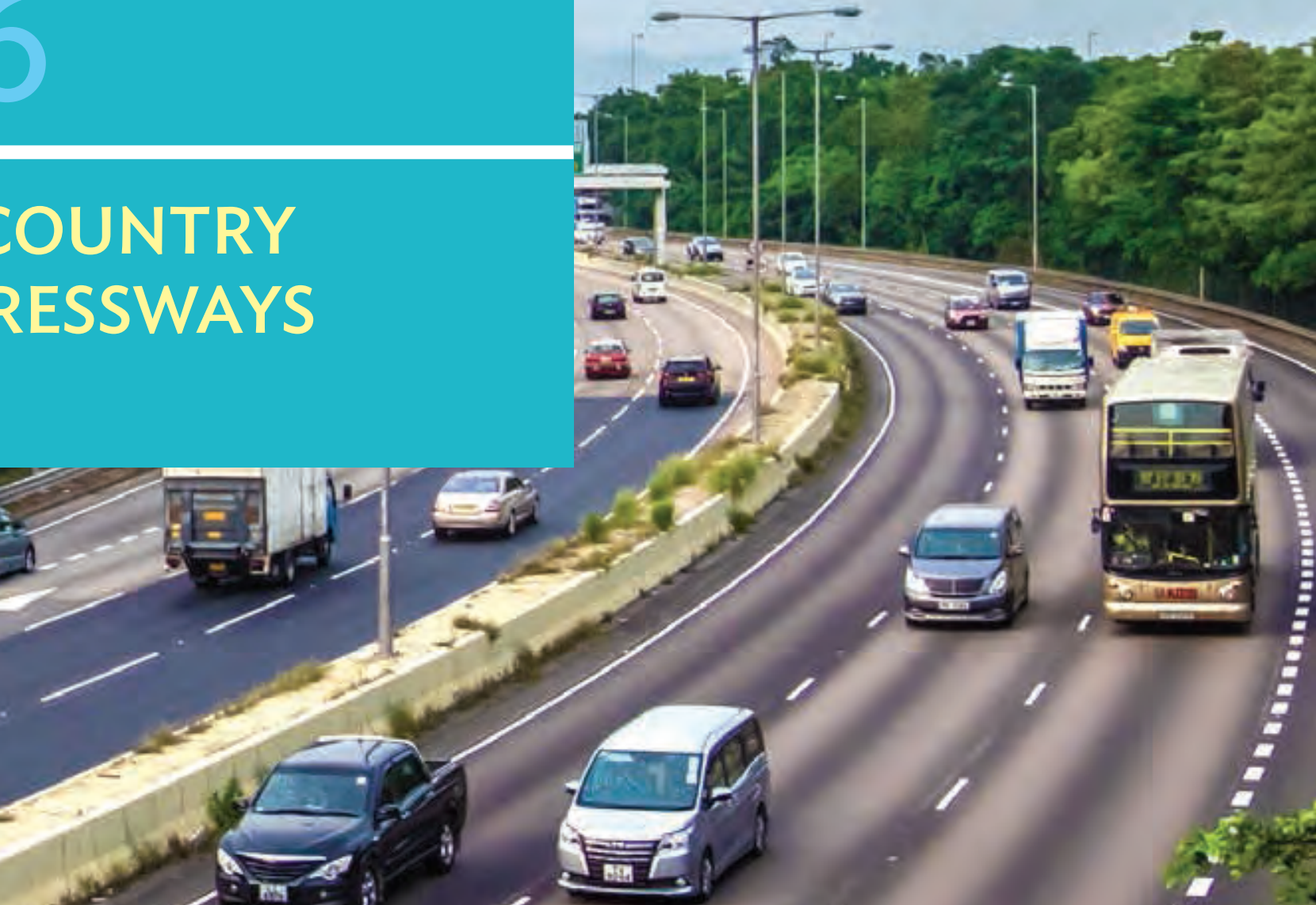


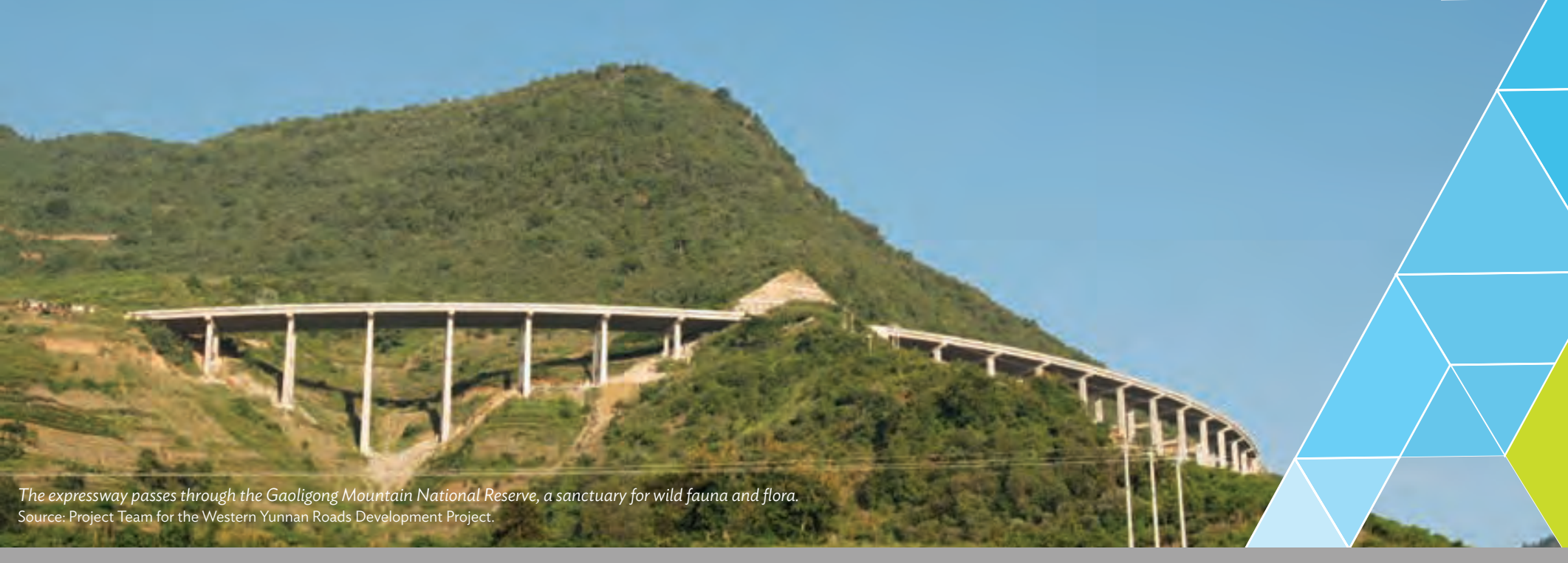

\section{HighWAY THROUgh THE HighLANDS:} INNOVATIVE RoAd IN THE PeOPLE'S RepUbLIC OF ChINA

The remoteness of Western Yunnan in the People's Republic of China is due to complex and hazardous terrain. Residents of isolated communities in the region had to travel for more than 3 hours to get to the nearest health clinic, market, or school.

In 2003, ADB approved the Western Yunnan Roads Development Project, which built an expressway and link roads, and rehabilitated over 200 kilometers of local roads. The expressway was customized to adjust to complex geological conditions, steep mountains, and frequent soil erosion. More than half of its length is made up of tunnels and bridges, with strategic locations and road spans that ensured road safety and environmental protection.

Since it opened in 2008 , the expressway has contributed to marked increases in incomes in the province, significant reductions in poverty rates, and drastic decreases in road accidents.

To other road projects that face similar conditions, the project offers lessons on geohazard treatment, environmental protection, and road safety measures, which are integrated into the expressway's road design, construction, and operation. 


\section{CONTEXT}

\section{omplex geological conditions and a fragile environment have contributed greatly to the isolation of Western Yunnan in the}

People's Republic of China. The roads are poor and insufficient. Mountainous terrain, unstable slopes, and varied surfaces make it difficult for remote communities to access basic public services and markets. Western Yunnan badly needed an expanded and improved road network.

Yunnan used to be a largely under-developed province. Its roads were usually congested and prone to landslides and fogs during the rainy season.' Seventy-three of the province's 128 counties were officially identified as poor, ${ }^{2}$ and the inadequate road condition had pushed many of them further into poverty. Yunnan's GDP in 2001 was $\mathrm{CNY}_{4,837}$ in $2001,64 \%$ of the national average. The western part of the province is the most geographically isolated, with crossing faults and incomplete folds lodged in a terrain of mountains and intermountain basins.

Western Yunnan has a very fractured and highly variable rock-substrate or surface, with inclined ridges above flood plains. Rockslides, severe slumping, and gully and sheet erosion are prevalent on many of its slopes. The geology and slope stability often change considerably over very short distances, with tilts averaging $20-45$ degrees, ${ }^{3}$ resulting in a continuous climb or descent in many areas of the road. The site also passes through a government-declared soil erosion prevention area and has 31 faults, 48 landslideprone areas, and 8 karst subsidence areas. Baoshan, one of the biggest cities in the province with a population of around 2.4 million, needed to be better connected to larger markets and public services. The city's poverty incidence was $29 \%$, a rate higher than the national average.

In 2003, ADB approved the Western Yunnan Roads Development Project to assist the Government of the People's Republic of China to remove transport barriers and reduce transport costs in Western Yunnan to promote pro-poor economic growth and thus reduce poverty and contribute to regional development in the GMS. ${ }^{4}$ However, what first seemed like an ordinary road network expansion project necessitated a major construction feat. The project constructed a 77-kilometer four-lane expressway through the province's very rough and hazardous terrain. The project also upgraded 294 kilometers of local roads to improve access to poor and ethnic minority areas.

Considering stability and safety in the design of the expressway, the project connected Baoshan to the southwestern Longling County. The expressway starts at the Daguanshi Village in Longyang, crosses eight other villages, and then connects with the Da-Bao Expressway (from Dali to Baoshan

\footnotetext{
ADB. 2011. Validation Report: Western Yunnan Roads Development Project in the People's Republic of China. Manila.

2 ADB. 2009. Performance Monitoring and Evaluation Report No. 8. Western Yunnan Road Development Project Baoshan-Longling Expressway Project. Manila.

3 ADB. 2002. Summary Environmental Impact Assessment. People's Republic of China: Western Yunnan Roads Development Project. Manila. http://www.adb.org/sites/default/files/projdocs/2002/prc_yunnan_roads.pdf

4 See related story on page 93
} 
and earth waste disposal in some sites. However, for the project's waste area, preliminary protection activities preceded construction activities, such as the setup of cutoff trenches, drainage ditches, and arresting walls.

\section{Technologically advanced expressway design. The}

expressway followed the contours of the mountains of Western

Yunnan, with half of its length made up of tunnels and bridges. The tunnels passed through mountains, while the bridges spanned deep valleys, rivers, and tributaries below.

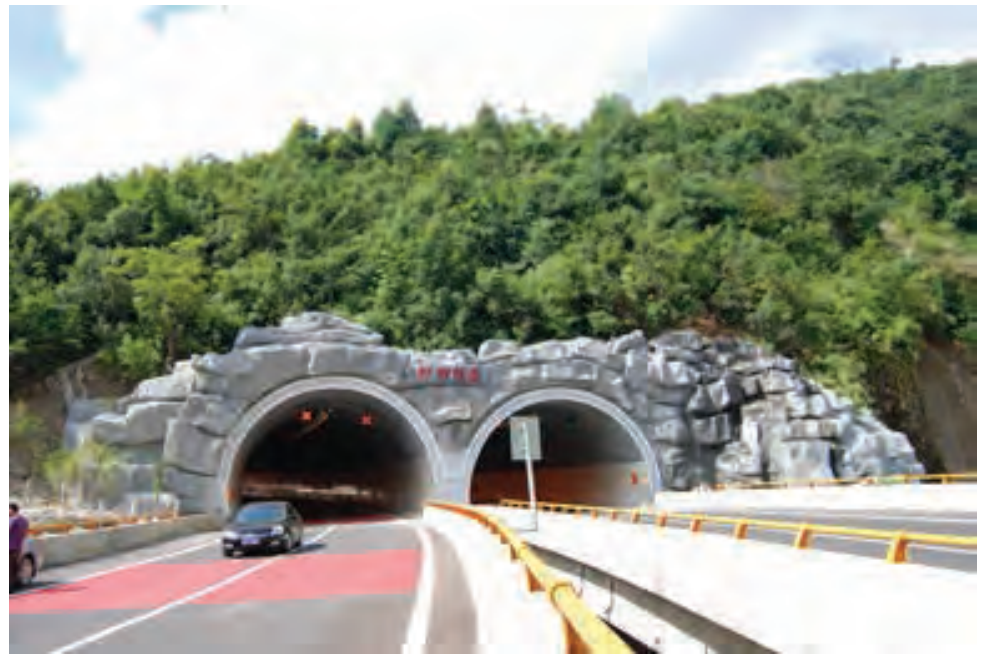

The tunnels of the expressway pass through mountains, while the bridges span deep valleys, rivers, and tributaries below.

Photo by: Project Team for the Western Yunnan Roads Development Project. The tunnels were especially difficult to construct, as they were mostly situated under the surface of mountain slopes made up of weathered rocks. ${ }^{6}$ They varied in length, from 125 meters to 2,920 meters, with a total length of 9.4 kilometers. The tunnels are two-lane roads, with an emergency walkway on each side of the tunnels. They were designed with two-stage lining, and the insides were sprayed with fire-protective material. At the end of expressway construction, the project had a total of 237 bridges, 203 passageways, four channels, and nine double-arch tunnels. This technologically advanced highway design was complemented by the construction and rehabilitation of local roads that feed into the expressway, which has largely expanded the number of project beneficiaries.

Road safety features. The project, with the active involvement of the police and automotive mechanical technicians, identified potential safety problems. It developed a three-dimensional simulation system to test the perception of driving and identify the safety black spots. The project introduced safety innovations, such as installing 11 escape ramps beside the areas of steep descents, as well as installing conspicuous caution signs to alert drivers. Traffic signs and guardrails were adequately provided along the route and reinforced road signs were provided at tunnel entrances, in the tunnels, at sharp curves, and at the tunnel exits. Red road marks were applied at sharp curves and fog warning signs were provided in foggy areas. A solar-powered traffic monitoring system, which includes an emergency communication system, was provided along the project expressway?

Preservation of the environment. The project utilized various approaches to preserving the environment. The strategic locations and lengths of the bridges and the tunnels helped preserve the environment by minimizing the need for deeper excavation works on the mountains and their slopes, and the damage to existing vegetation and the natural environment. To ensure water and soil conservation, landscaping and planting activities were implemented right after the completion of slope cutting. Bridge runoffs were piped into sedimentation ponds, while roadway runoffs were diverted over grass. Energy-saving facilities were also installed in the tunnels and used for the all-day traffic monitoring system.

6 COWI. 2009. Baoshan Longling Expressway. http://www.cowi.com/menu/project/BridgeTunnelandMarineStructures/Tunnels/ SCLandrocktunnelling/Documents/0233-1706-030e-09b_low.pdf

7 ADB. 2011. Completion Report: Western Yunnan Roads Development Project in the People's Republic of China. Manila. 
Integration with local cultural and tourism sites. An added value of the project is the way the expressway integrated the scenery into the design. It featured pit stops where tourists and ordinary motorists alike can stop to rest and dine while enjoying the scenic view atop the Western Yunnan mountains. It also included corridors to facilitate the migration of animals living in the heritage and protected sites along the expressway.

\section{RESULTS}

The expressway built by the Western Yunnan Roads Development Project has contributed significantly to reducing poverty in the province while preserving and protecting the natural environment and offering safe passage through the mountainous regions of Yunnan.

Road safety and environmental protection. The expressway was completed in September 2008 , with the expressway's design customized to suit the site's complicated geological conditions. The construction quality, the effectiveness of road safety control, and environmental protection substantially exceeded expectations. Records of the Traffic Police Office of the Public Security Bureau of Baoshan showed that the number of traffic collisions in the project area was reduced to 16 in 2008 and 15 in 2009, compared with 34 in 2006 and 23 in 2007. Casualties were also reduced to 32 persons in 2008 and 22 in 2009, from 90 in 2006 and 54 in 2007 (footnote 6). The project, while ensuring road safety, also strived to minimize environmental damage during project implementation. Almost $98 \%$ of land involved in construction activities was either treated or restored, and vegetation recovery rate reached $98.4 \%$.

Rural poverty reduction and socioeconomic impact. The expressway has also substantially contributed to reduced poverty levels and increased incomes, trade, and employment in the project site while lowering transport costs. Rural poverty in Baoshan City was reduced to $8.6 \%$ in 2008, in Longyang District by 7.6\%, and Longling County by 15.8\%. Per capita net income increased yearly by $14 \%$ in Baoshan, $12.2 \%$ in Longyang, and $11.8 \%$ in Longling.

The project also contributed to the annual increase in per capita GDP from 2004 to 2008 in the project area. In Baoshan, GDP increased an average of $17.7 \%$, in Longyang District by $19 \%$, and Longling County by 20.9\% - high, compared with the provincial average of $11.1 \%$ per year.

The project contributed to the increased incomes of the local populace. From 2004 to 2008, the farmers' per capita income increased annually, ranging from 7.7\% to 15.9\% in Longyang District and Longling County. During the construction of the expressway, the project was also able to contribute to job generation and increased incomes in the province. In 2006, the project was able to hire a total of 11,410 laborers from poor households to work on the construction site. The project also helped increase the locals' skills in construction. Some of the local road construction workers have already moved on to other construction projects. Upon completion and actual opening, the project also employed local people to act as traffic security guards, toll gates personnel, monitoring stations personnel, and staff stationed in or near tunnels. Local villagers were also hired as road cleaners for the expressway.

Transport services. The expressway has also substantially reduced travel time in Yunnan. Before the highway was constructed, going to Longling from Baoshan took 4-5 hours by car, and up to 6 hours by trucks. Upon completion of the highway, travel time was reduced to about 1.5 hours. Freight traffic 
increased to 197,400 tons in 2008 from 28,200 tons in 2004, and the number of passengers increased to 11.8 million from 8.4 million in 2004. The project also increased access by the poor to markets and social services. A sample survey of 26 villages traversed by the expressway showed that $100 \%$ of the villagers, up from less than two thirds in 2004, can reach markets and secondary schools in 30 minutes and health clinics in 10 minutes after the expressway was opened. ${ }^{8}$

Clearly, the long, steep, and winding road of the Western Yunnan Expressway has led to

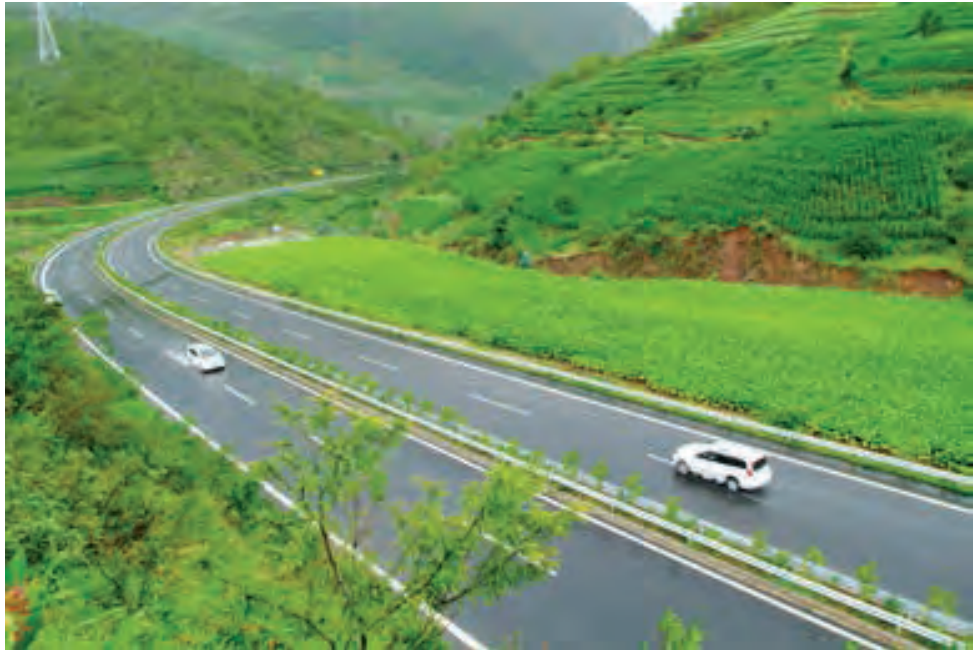

The project built a four-lane expressway that helped connect the remote province of Western Yunnan to markets and basic services.

Photo by: Project Team for the Western Yunnan Roads Development Project. multiple benefits for Yunnan and its residents, beyond what the project expected in the beginning. It features a highly tailored and innovative highway design, mixed and matched with various safety and environmental features. Now, this infrastructure is helping lift the lives of many impoverished people in the province.

\section{LESSONS}

Innovations in highway design do not have to mean out-of-the-ordinary road architecture. In ADB's Western Yunnan Roads Development Project, the measures used to build the expressway were optimal because they embraced geohazard treatment, environmental protection, and road safety measures and integrated all of them into the road design, construction, and operation. These are lessons that can be shared with other road projects faced with similar conditions.

Investigate geohazards. A thorough geohazard investigation accomplished before construction can help guide the proper design of the highway in a geographically challenging location. This should be done before project design completion to ensure that steps to be taken during project implementation are informed and well-thought out. This would improve project quality and avoid costs in maintenance and operation.

Synchronize construction and environmental protection activities. It is best to synchronize construction activities and environmental protection measures during road project implementation. Cleanup, restoration, and revegetation should be done immediately at the early stage of road operation. This step helps avoid soil erosions or landslides after the opening of the road.

Prioritize road safety. Road safety should be a priority for road design and implementation. A three-dimensional simulation system used during road design can be an effective tool to identify safety black spots. Roadside resting areas at scenic viewpoints can provide drivers sufficient rest,

8 ADB. 2011. Validation Report. Western Yunnan Roads Development Project in the People's Republic of China. Manila. 
reducing fatigue while driving. In addition, more visible and frequent road signs, guard rails, escape ramps, and sufficient lighting should be provided during road construction.

\section{Keywords:}

Road transport, expressway, highway, road safety, tunnels, bridges, tourism, Western Yunnan Roads Development Project, land transport, People's Republic of China

\section{For further reading:}

- Project web page: https://www.adb.org/projects/32336-013/main

- Highway in the Mountains - The Western Yunnan Roads Development Project: https://www. adb.org/publications/highway-mountains-western-yunnan-roads-development-project

- Transport in the People's Republic of China: Highway Brings Business: https://www.adb.org/ results/transport-peoples-republic-china-highway-brings-business

\section{For further information:}

- Chenglong Chu, Senior Portfolio Management Officer, East Asia Department | cchu@adb.org

- Tyrell Duncan, Technical Advisor (Transport), Sustainable Development and Climate Change Department|tduncan@adb.org

- Ki-Joon Kim, Principal Transport Specialist, Sustainable Development and Climate Change Department|kjkim@adb.org

- Dongxiang Li, Lead Regional Cooperation and Integration Specialist, Economic Research and Regional Cooperation Department | dongxiangli@adb.org

\section{Expressway to Development: The Greater Mekong Subregion Kunming-Hai Phong Transport Corridor-Noi Bai-Lao Cai Highway Project}

The border shared by Yunnan Province in the People's Republic of China (PRC) and Lao Cai Province in Viet Nam is a major trade gateway, but the lack of a high-standard highway in northern Viet Nam became a major factor in the slow pace of development. The existing 400-kilometer national highway from Noi Bai, winding through the provinces of Vinh Phuc, Phu Tho, Yen Bai, and Lao Cai was poorly designed and maintained, which delayed the transport of goods and people.

In 2005, the Government of Viet Nam sought ADB's help in planning a national expressway from the capital Ha Noi to Lao Cai Province to cut travel time and distance and provide safe passage for goods and people. The highway would usher in economic growth in northern Viet Nam and boost the economy of the larger Greater Mekong Subregion (GMS). In 2007, ADB approved the GMS Kunming-Hai Phong Transport Corridor-Noi Bai-Lao Cai Highway Project. Construction of the Noi Bai-Lao Cai Highway began in 2009 and was opened to traffic in September 2014. 
Crucial link. The Kunming-Hai Phong Transport Corridor offers a more direct route from Kunming City in Yunnan Province, PRC to Hai Phong, Viet Nam. It is part of the NorthSouth Economic Corridor, a larger initiative under ADB's GMS Program, which aims to promote economic cooperation among GMS countries. Under the economic corridor, the Kunming-Hai Phong Transport Corridor is considered as an important trade route and plays a critical role in providing Yunnan Province access to important seaports.

The Noi Bai-Lao Cai Highway Project provides the crucial link in the Kunming-Hai Phong Transport Corridor. The northern end of the highway at the border in Lao Cai connects to another highway to Kunming City. The southern end at Noi Bai Airport in Ha Noi connects to the already improved Ha Noi-Hai Phong Highway, which links Ha Noi to the international seaport in Hai Phong on Viet Nam's northeastern coast.

Direct route. The initial plan was to restore and widen the existing national highway, until a feasibility study confirmed the viability of a new grade-separated and access-controlled highway designed according to international standards. Unlike the national highway which follows the natural contours of Viet Nam's hills and mountains, the new Noi Bai-Lao Cai Highway is shorter, wider, and has a straighter alignment. At 244 kilometers, its length is just over half of the existing highway. The highway was built through the mountains, by the right bank of the Red River, and offers reduced risk of accidents as it eliminated steep mountainside turns and the need for bridges.

The Noi Bai-Lao Cai Highway was designed as a four-lane dual carriageway in areas with projected higher traffic volume and a two-lane single carriageway where traffic is relatively low. Provision for additional two lanes are included in the design, to be completed when traffic volume reaches capacity. The highway includes 10 interchanges with toll booths, 5 service areas, and a tunnel. It is equipped with modern electric, communication, and tolling systems and facilities.

Completed corridor. The straight alignment allows for the safe and easy passage of long cargo trucks, saving shipping companies of fuel costs and travel time. Before, freight was transported loaded in small, light delivery trucks since the longer vehicles were incapable of navigating the sharp curves and disallowed from crossing the low-capacity bridges along the route. The 10-hour travel time from $\mathrm{Ha}$ Noi to Lao Cai has been reduced to only 3 hours. Travel costs have also been reduced. Yen Bai, the first major city north of Ha Noi and halfway to the border, is now bustling with tourist activity as roadside restaurants, travel agencies, and other businesses mushroomed. In Lao Cai, new hotels, cafes, and shops heaving with goods from across the border have sprung. Bus companies have invested in new vehicles to take advantage of the huge demand from travelers. Closer to the border, the mountain town of $\mathrm{Sa} \mathrm{Pa}$, with its famous rice terraces and ethnic minority villages, is welcoming more and more visitors every day.

By March 2015, about 6 months since the highway opened, cross-border traffic to the PRC has risen by at least 15\% per month, while vehicles entering Viet Nam increased by $30 \%$. At the border gates, new computerized facilities now help speed up customs and 
immigration processes. With Kunming closer to Hai Phong, international cargo traffic can now divert to the Kunming-Hai Phong Transport Corridor.

\section{References:}

- Project web page: http://www.adb.org/projects/33307-023/main

- ADB. 2002. Preparing the Kunming-Hai Phong Transport Corridor Project. Manila. https://www.adb.org/sites/default/files/project-document/70784/tar-vie-33307.pdf

- Viet Nam's Expressway to Everywhere: https://www.adb.org/results/viet-namsexpressway-to-everywhere

\section{Contact:}

Yasushi Tanaka, Principal Transport Specialist, Southeast Asia Department | ytanaka@ adb.org 


\section{CONTEXT}

\section{he development of southern Sri Lanka was constrained by poor road connectivity. Long-awaited development in the} region has been hampered by the lack of efficient transport links to other parts of the country, particularly to the commercial capital Colombo and the economically dominant Western Province.

Sri Lanka's domestic economy relies highly on its road network. Of the country's 95,000-kilometer road network, about 10,500 kilometers are national highways, 15,000 kilometers are provincial roads, and the rest are local residential roads. Most roads, however, are over 50 years old and were not designed for increased traffic volumes. Domestic aviation is almost nonexistent, local passenger shipping is minimal, and the railway network is old and inefficient. ${ }^{2}$

The state-owned Road Development Authority manages all national highways, which are mostly two-lane roads. The existing National Highway A2, which follows the coast from Colombo Port to Matara, is lined with substantial unregulated commercial and residential developments on both sides. Traffic is slower than one would expect on a highway, as pedestrians, bicycles, and animal-drawn carts compete with motor vehicles for space and swift passage. Cars and motorcycles make up most road traffic, while buses are the main mode of transportation for the poor. The highway is poorly maintained, discouraging long-distance travel and preventing the spread of economic activities from urban Colombo to the rural south. The combination of uncontrolled roadside development, poor road maintenance, and increasing vehicle volume provides a formula for road accidents, which mainly affect the poor who do not own vehicles. Sri Lanka's road accident fatality rate is high, around 18 times higher than in developed countries. Of the 2,000 fatalities in 1998, 42\% were pedestrians and $15 \%$ were cyclists.
PROJECT SNAPSHOT

Sri Lanka: Southern Transport

Development Project

Approval date: NOVEMBER 1999

Amounts: \$186 MILLION LOAN

$\$ 339$ MILLION - JAPAN BANK FOR INTERNATIONAL COOPERATION

\$3.7 MILLION - NORDIC DEVELOPMENT FUnd

\$O.8 MILLION - SWEDISH INTERNATIONAL DEVELOPMENT CoOperation Agency

$\$ 159.5$ MILLION - EXPORT-IMPORT BANK OF CHINA

Borrower:

GOVERNMENT OF SRI LANKA

Executing agency: Ministry of Higher EdUCATION AND HIGHWAYS ${ }^{6}$

Geographical location: SOUTHERN SRI LANKA

Transport project: ROAD (NON-URBAN)

Completion date: JULY 2013

The Government of Sri Lanka, in 1999, sought ADB's assistance in cofinancing the Southern Transport Development Project to bring economic growth and improve road safety in the southern region. The project involved the construction of the 126-kilometer access-controlled Southern Expressway from Kottawa near Colombo to Godagama near the southernmost city of Matara. The project also included a total of 15 kilometers of access roads from the expressway to the $A_{2}$ near the coastal towns of Panadura and Galle.

1 In the original loan, the executing agency was identified as the Ministry of Transport and Highways, which was subsequently converted in to two ministries: the Ministry of Transport and the Ministry of Highways. At approval of the supplementary loan in 2008, the executing agency was identified as the Ministry of Highways and Road Development, which in 2013 was renamed the Ministry of Highways, Ports and Shipping. By the project's closing, the Ministry of Higher Education and Highways served as executing agency.

2 Sri Lanka's roads carry $90 \%$ of traffic, railways $7 \%$, and coastal shipping $3 \%$. The railway network comprises about 1,450 kilometers of track built mostly between 50 and 100 years ago. It remains an important transport mode for urban commuters, but operations and maintenance can be costly (1999 figures). 


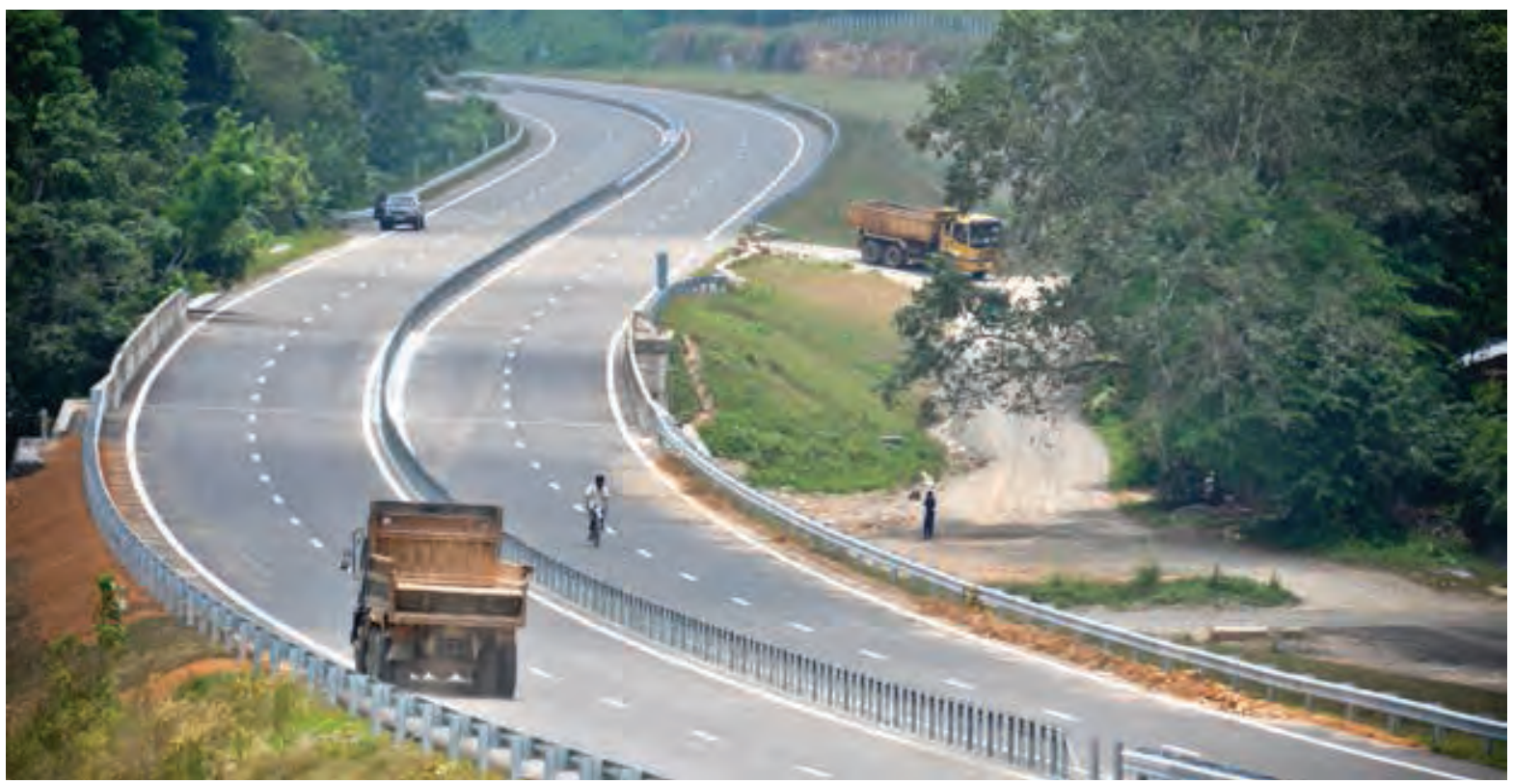

The ADB-financed section of Sri-Lanka's first limited-access expressing, the Southern Transport Development Project. James Hutchison | ADB Photo Library.

The full length of the Southern Expressway, now called Eo1, was finally opened to the public in March 2014. Eo1 took 13 years to complete, originally expected to be completed within 6 years.

\section{SOLUTIONS}

ADB's Southern Transport Development Project constructed a 126-kilometer expressway, while addressing the project's impact on the lives of peoples and communities.

Choosing a new highway alignment. A Master Plan Study in 1996 by the Japan International Cooperation Agency (JICA) determined the need for the new expressway. Various studies on the preliminary designs, project viability and safeguards were conducted. ${ }^{3}$ The project also benefitted from the engineering perspectives, social and economic, and environmental impact studies of ADB, the University of Moratuwa, and the government's own Road Development Authority, which also served as the project's implementing agency.

Improving the A2 was rejected because of the potential high resettlement cost of the extensive commercial and residential developments on both sides of the highway. Also, A2 has been subjected to heavy erosion due to its proximity to the sea and already requires costly rehabilitation and protection. A new highway through the less developed and far more poverty prone hinterlands of the southern region would deliver far greater development benefits.

As early as 1999, the Government of Sri Lanka foresaw that the Southern Expressway would ultimately be a six-lane, high-capacity, limited-access express highway, and adopted a construction

3 The project has leveraged knowledge provided under previous non-related ADB technical assistance. These included a prefeasibility study for the highway project by the Road Development Authority in 1993, which was subsequently updated through an economic feasibility study by the University of Moratuwa in 1997; an ADB project preparatory study in 1997; and a second ADB project preparatory project in 1999 to assist the Road Development Authority in reviewing earlier economic analysis and assessing environmental impacts. 
approach that provides for future highway expansion. The Southern Expressway was divided into four sections. Section I, from Kottawa to Dodangoda, has a length of 34.9 kilometers; Section II, from Dodangoda to Kurundugahahethekma, has a length of 31.7 kilometers; Section III, from Kurundugahahethekma to Pinnaduwa, has a length of 27.7 kilometers; and Section IV, from Pinnaduwa to Godagama, has a length of 32.2 kilometers. Section I was designed as a four-lane standard highway, while sections II-IV would initially have two lanes, with provisions for expansion to four lanes. Upgrade was scheduled after 2010, about a decade since the project started. However, during implementation, traffic growth from 2000 to 2005 had been higher than forecasted in 1999.

JICA financed the construction of Sections I and II, totaling 66.6 kilometers and completed in August 2011. Preliminary and detailed engineering for the ADB-financed section of the expressway was financed through a separate ADB project. ${ }^{4}$ Sections III and IV were originally financed under the ADB project loan, whose main scope was the construction of a two-lane highway and the Galle Port Access Road. When the government decided to upgrade Sections II-IV of the expressway from two to four lanes in 2006, both JICA and ADB processed additional financing to accommodate the change of scope and cost overruns. ${ }^{5}$

In 2006, the government decided to advance the upgrading of Sections II to IV to four lanes to keep up with increasing traffic volume, which led to the extension of the project timeframe and additional construction costs. Nevertheless, the expansion to four lanes simultaneous with the two-lane construction resulted in substantial time and cost savings and reduced disruption of commercial activities caused by construction works.

Addressing impacts on affected people. As a greenfield project, the land lost to the expressway consisted of agricultural land, forest areas, wetlands, and the catchment areas of five rivers. About 1,326 households were displaced, while 600 households were indirectly affected, including families of agricultural laborers who had worked on farms and plantations that had to close.

Resettlement of the affected families became difficult. The project faced a number of public protests at the beginning regarding the land acquisition and compensation process. Objections were raised by different groups and affected people. ${ }^{6}$ While many families found new homes in the resettlement areas, some opted to relocate on their own. To manage public relationship, the Road Development Authority established a project communication plan in 2005 and ran several public awareness campaigns. Land acquisition and resettlement committees were established under the project's resettlement implementation plan to redress grievances.

Various civil society groups helped the government in overseeing aspects of resettlement. They also worked with the new communities in restoring their incomes and livelihoods. An income restoration program, initiated in 2005, focused on income-generating livelihood activities, strengthening housing societies in resettlement areas, and home gardening around resettlement sites. The Road

4 ADB.1999. Report and Recommendation of the President to the Board of Directors: Proposed Loan to the Democratic Socialist Republic of Sri Lanka for the Road Network Improvement Project. Manila.

5 An ADB supplementary loan covered the cost overrun for the continuing construction of the two-lane highway in the Kurundugahahethekma-Pinnaduwa interchange section, the additional expansion of the Galle access road to a four-lane highway, and additional provision of road safety equipment. ADB. 2008. Report and Recommendation of the President to the Board of Directors: Proposed Supplementary Loan and Technical Assistance Grant to the Democratic Socialist Republic of Sri Lanka: Southern Transport Development Project. Manila.

6 The project has a long history of objections to the change in road alignment and subsequent land acquisition. Various groups of affected people brought their objections to court, resulting in delays in land acquisition in some road sections. ADB. 2014. Completion Report: Southern Transport Development Project in Sri Lanka. Manila 
Development Authority signed an agreement with an NGO to facilitate the program. However, after a review deemed the NGO's performance as unsatisfactory, the Road Development Authority terminated the NGO's contract in February 2008 and implemented a restructured program, which was completed in November 2010.

Road safety. The project also focused on road safety initiatives financed by multiple donor agencies including ADB, JICA, the Nordic Development Fund, the Swedish International Development Cooperation Agency, the Export and Import Bank of China. ADB financed the road safety program, which involved establishing and strengthening traffic safety institutions. ${ }^{7}$ Road safety equipment was financed by the Nordic Development Fund. However, procurement of such equipment was constrained by changes in institutional set up and priorities so that only a limited number of items were procured. Computer equipment and software for the accident data system as well as equipment for traffic police were installed. Road safety consulting services funded by Swedish International Development Cooperation Agency provided assistance to the Road Development Authority to further improve traffic safety.

ADB's supplementary loan and the second JICA loan also financed the procurement of equipment required to operate the expressway, which included an advanced traffic management system to centrally monitor the expressway; weigh stations to control overloading; speed monitoring equipment; and ambulances, police vehicles, rescue equipment, and other ancillary services.

\section{RESULTS}

As the largest greenfield road project ever implemented in the country and a milestone in Sri Lanka's development history, ADB's Southern Transport Development Project gained much public attention, donor financing, and private sector interest.

\section{Resettled communities and restored household incomes. Out of 1,295} households that were to

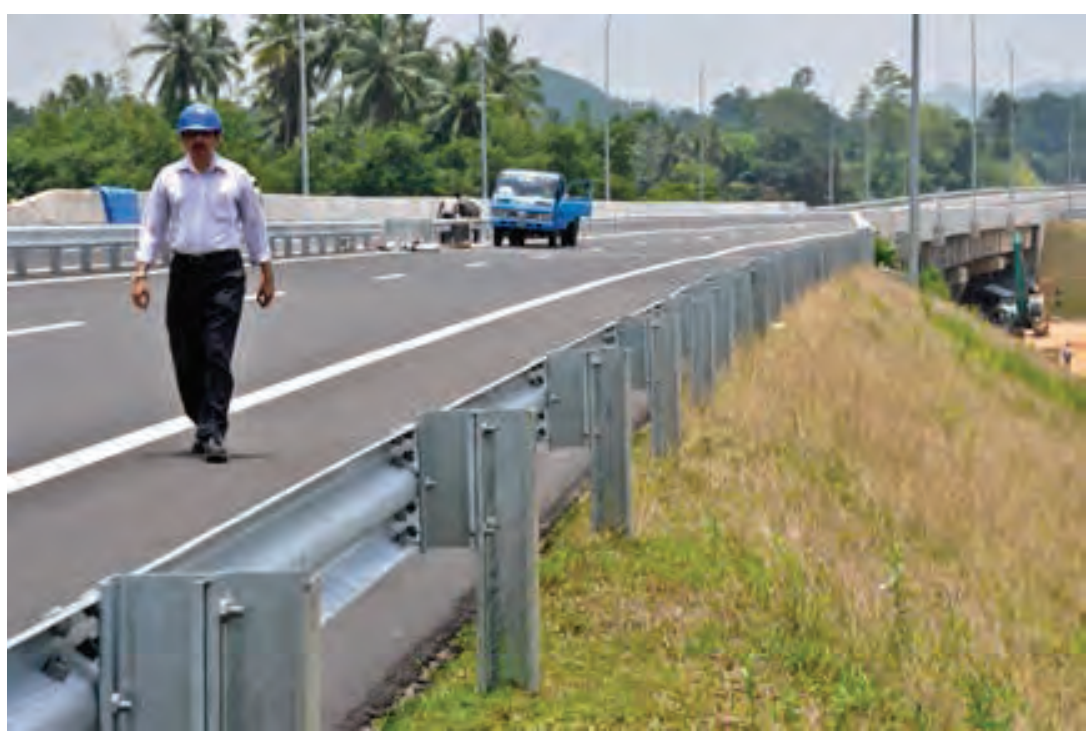

Worker inspects the highway. James Hutchison | ADB Photo Library. be resettled, 827 had found land by themselves and had resettled, while 468 were settled in 32 resettlement sites developed by the Road Development Authority. These sites were provided with public services such as water, electricity, and telecommunication. Internal roads, culverts, and common land for recreation, cemeteries, and community halls were also included.

7 The Road Safety Unit within the Road Development Authority and National Road Safety Secretariat under the Ministry of Highways were established to improve traffic safety. 
To assist resettled families in restoring their lost income, several skills training programs were conducted with the help of several institutions such as local centers of the Vocational Training Authority, provincial Department of Agriculture, and local depots of the Sri Lanka Transport Board in the Western Province and Southern Province. Many households were also assisted in developing home gardens and were provided materials, such as pots, plants, and fertilizer. Necessary training and experience-sharing tours and distribution of plants, seeds, and pots were also conducted. Vulnerable groups, such as households headed by women and the aged, were given special attention. Despite difficulties faced by resettled households over land acquisition, displacement, and resettlement, in general, most households gradually overcame their problems and have consolidated their lives to a reasonable degree in the new resettlement locations.

\section{Expressway to} development. Travel time from Colombo to Galle, which usually takes 4-5 hours, now only takes 1.5-2.0 hours. Consumer goods, such as fish, farm produce, and

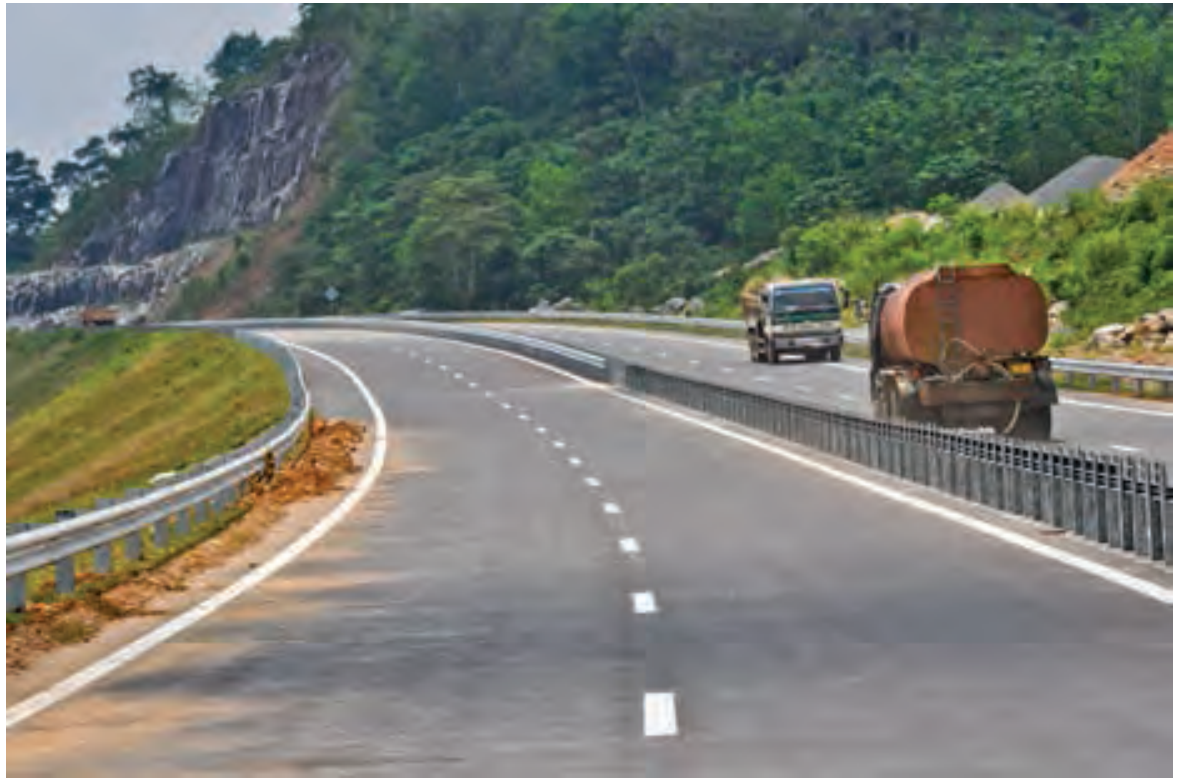

Over 40,000 vehicles ply the expressway daily since it was opened to the public. James Hutchison | ADB Photo Library.

even cars from the Colombo Port on the way to Galle or Matara, now reach their destination in less time. With road safety measures and equipment in place, more people now prefer to travel via the Eo1 than the A2. Over 40,000 vehicles, mostly cars, now ply the expressway each day, netting toll fees of around SLRs17.5 million (\$118,000). A dedicated bus service also travels the expressway. The expressway has also created jobs in the south and is also generating independent business livelihoods, particularly for those living around the seven interchanges. Land prices for housing and industrial projects have virtually doubled. The number of tourists in historical Galle has started to soar again, ever since the city was almost completely devastated by the 2004 Asian tsunami. Hotels, restaurants, tour operators, and small tourism-related businesses in and around the historical attraction of Galle Fort are thriving since the expressway opened. The private sector has been helping in developing commercial areas near the expressway's interchanges and exploring business opportunities in manufacturing, tourism, agriculture, fisheries and aquaculture, and related services.

\section{LESSONS}

ADB's Southern Transport Development Project offers lessons in implementing large infrastructure projects involving multiple development partners and affecting many people and communities. 
Consult all stakeholders, especially affected people. Even with the best compensation package for displaced people, the project faced strong public protests at the beginning regarding the land acquisition and compensation process. To manage relationship with the public and affected people, the Road Development Authority established a project communication plan in 2005 and ran several public awareness campaigns. A grievance redress system, in this project's case, the land acquisition and resettlement committees, needs to be established as early as possible. Managing public and stakeholder relationship is an important part of successful project management. Meaningful consultations, early engagement, and awareness programs for the public and other key stakeholders through local media and other means are crucial to avoid a disgruntled public and the risks of complaints and delays.

Create a project unit for interagency coordination. In very large and costly infrastructure projects, it pays to have support from various international agencies. The Government of Sri Lanka had no shortage of partners. Various insights and perspectives from development partners were crucial in the development of the highway design that can easily be upgraded to accommodate increasing traffic and the imminent social and economic development in the south. The project's funding partners demonstrated great patience and flexibility to allow further development of the project concept during the early stage of project implementation and ensured the relevance of project outputs. To support interagency coordination, a project unit may be created to improve communication, resolve overlaps in financing, and address other challenges.

\section{Keywords:}

expressway, road safety, resettlement, cofinancing, Southern Transport Development Project, land transport, Sri Lanka

\section{For further reading:}

- Project web page: http://www.adb.org/projects/26522-013/main\#project-overview

- Project supplementary financing web page: http://www.adb.org/projects/26522-023/main

- Sri Lanka Transport: Expressway between Colombo and Galle Improves Trade. http://www.adb. org/results/sri-lanka-transport-expressway-between-colombo-and-galle-improves-trade

\section{For further information:}

- Aruna Uddeeptha Nanayakkara, Senior Project Officer (Road and Transport), South Asia Department|ananayakkara@adb.org

- Tyrrell Duncan, Technical Advisor (Transport), Sustainable Development and Climate Change Department|tduncaan@adb.org

- Ki-Joon Kim, Principal Transport Specialist, Sustainable Development and Climate Change Department|kjkim@adb.org

- Dongxiang Li, Lead Regional Cooperation and Integration Specialist, Economic Research and Regional Cooperation Department | dongxiangli@adb.org 


\section{$\left(1+2 x^{2}+3\right.$ \\ a.s.}

H.

ax.

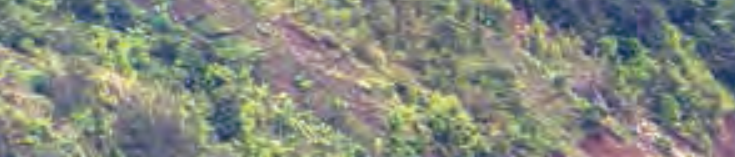

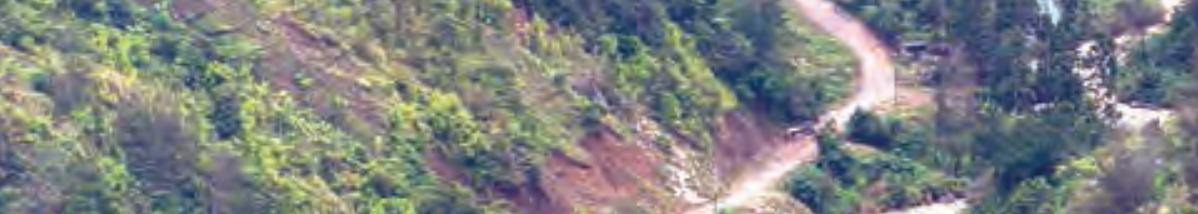

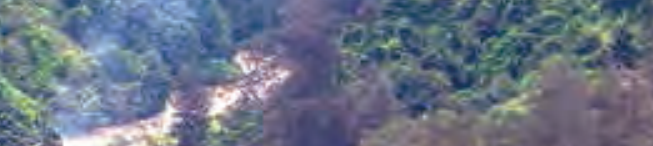

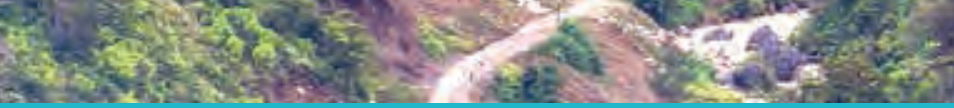

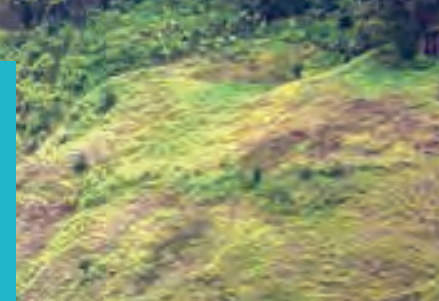

\section{RURAL ROAD CONNECTIONS}

(5)

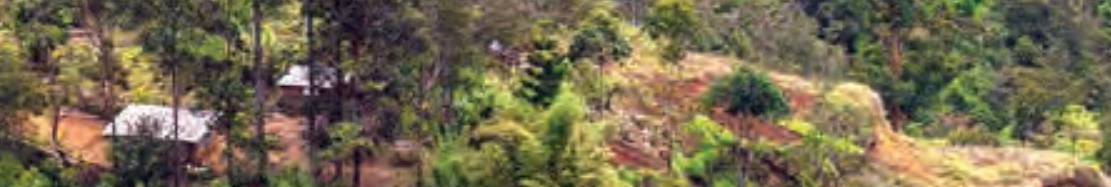

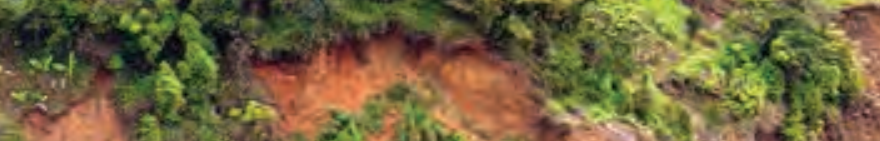

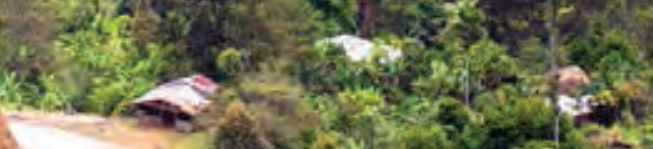

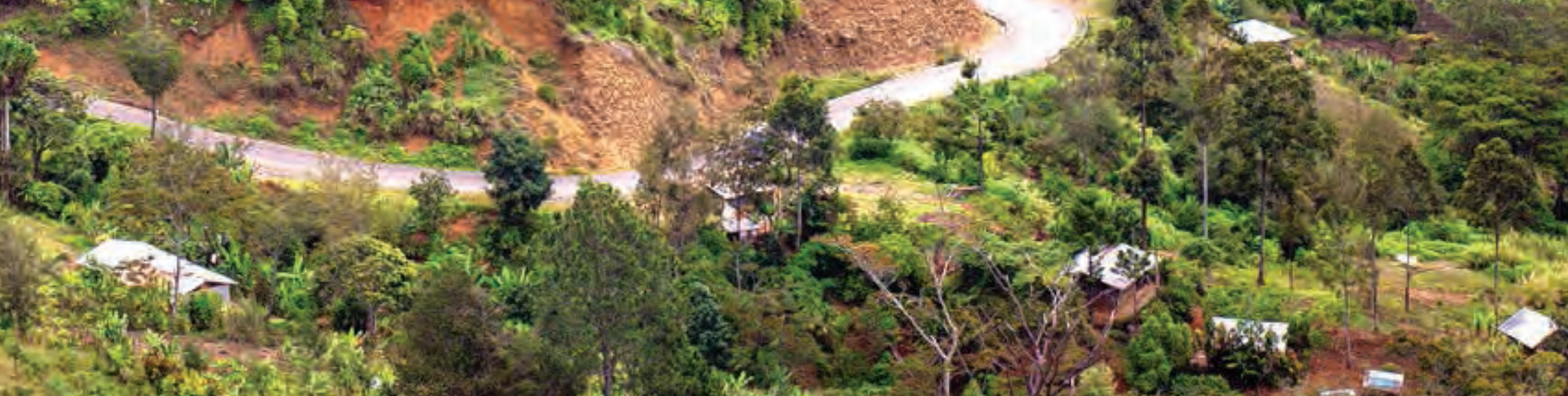

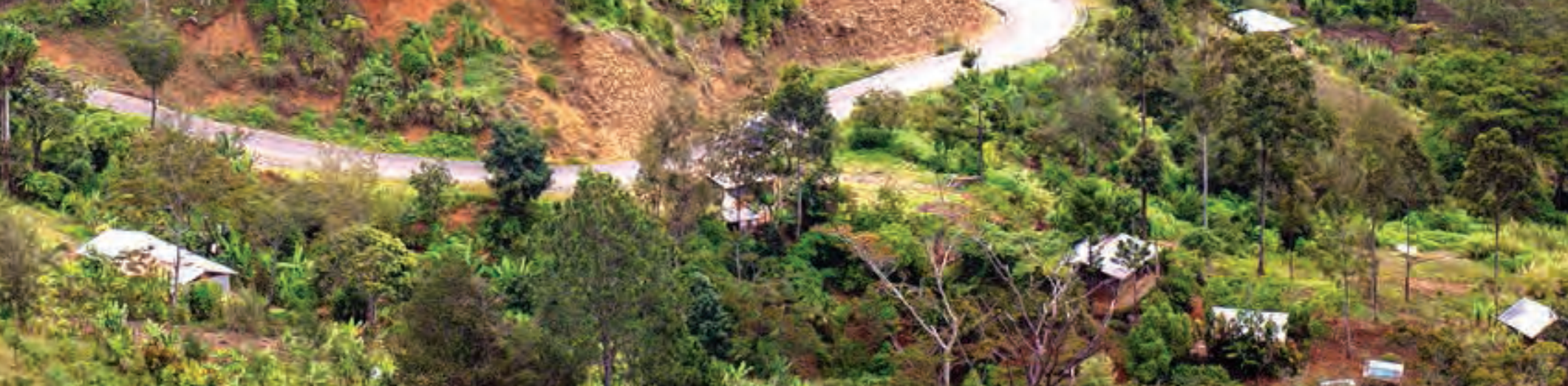

- $x, y=0$ 


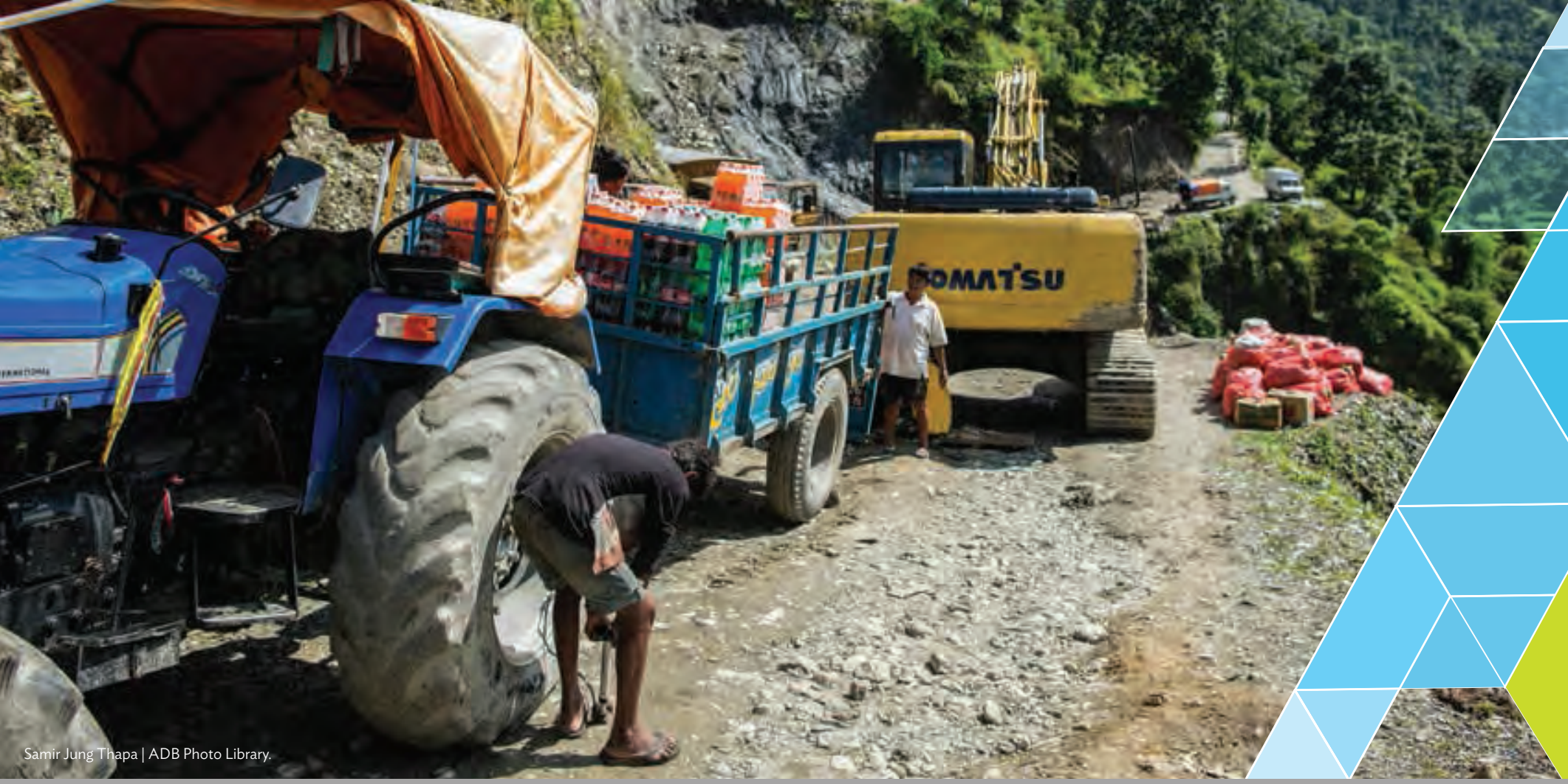

\section{PaVing the Way to Change:}

Creating a Safe Road Environment in Rural Cambodia

Cambodia's rural roads needed to be upgraded to provide remote agricultural areas with better links to main highways and further on to markets and commercial centers.

ADB's Rural Roads Improvement Project, approved in 2010, paved about 545 kilometers of rural roads in seven provinces around the Tonle Sap Basin. The project also improved road asset management and increased awareness on road safety and potential social problems from road development.

The newly paved rural roads improved connectivity of rural communities to commercial centers. Awareness programs on road safety and social impacts of road development involving various stakeholders highlighted the importance of a safe road environment.

The project recommends understanding of road user behavior in improving road safety and using loan proceeds to finance the design of similar future projects. Building a strong and committed project team ensured the project's success. 


\section{CONTEXT}

$\mathrm{R}$

ural roads in Cambodia are in dire condition. Mostly unpaved, these roads provide poor links for rural communities to major highways that lead to commercial centers with bigger markets, more job opportunities, and social services. They slow down the growth of the rural economy.

The mobility of goods and people in Cambodia relies highly on the country's extensive, but largely decrepit 51,746-kilometer road network. The Ministry of Public Works and Transport manages 5,623 kilometers of national highways and 6,641 kilometers of provincial roads, while the Ministry of Rural Development manages about 39,500 kilometers of rural roads. Despite efforts that have increased the length of the paved national road network, many provincial roads and most rural roads remain unpaved. Rural roads are typically earth or gravel roads, about 5 -6 meters wide, and experience low to moderate traffic daily. Average daily traffic volume ranges from 200-2,000 passenger car units, depending on the road section. Motorcycles make up over $80 \%$ of the traffic. Annual traffic volume is increasing and is expected to increase in the coming years.

Road safety is a major issue, as Cambodia has one of the highest incidences of road crashes in the world. In 2014, the country registered 14 fatalities per 100,000 people-the second highest in Southeast Asia. Most crashes are caused by human error, notably by speeding and drunk-driving. In rural areas, almost all motorcycle drivers do not possess a driver's license. Licensing, vehicle registration, and insurance systems were lacking as well as effective police enforcement. Many motorists also lack knowledge on safe driving techniques, road safety, and traffic signs and rules.

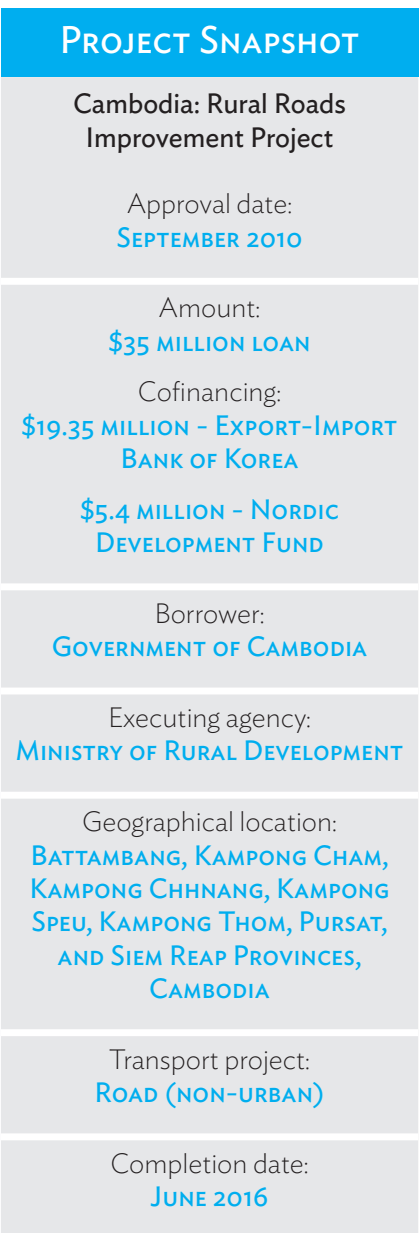

In 2010, ADB launched the Rural Roads Improvement Project to improve Cambodia's rural road network by upgrading rural roads from gravel or dirt to paved condition, while raising awareness on road safety and mitigating potential social impacts. The roads are in seven provinces around the Tonle Sap Basin, among them, Battambang, Kampong Cham, Kampong Chhnang, Kampong Speu, Kampong Thom, Pursat, and Siem Reap. These roads link with the already paved primary national road network and provincial road network to provide smooth all-weather access to rural communities.

The Rural Roads Improvement Project was completed in 2016.

1 The traffic growth rate is forecast to increase by 7.2\%-12.0\% per annum. ADB. 2010. Report and Recommendation of the President to the Board of Directors. Proposed Loan to the Kingdom of Cambodia for the Rural Roads Improvement Project. Manila. http://www.adb.org/ projects/documents/rural-roads-improvement-project-cambodia-rrp 


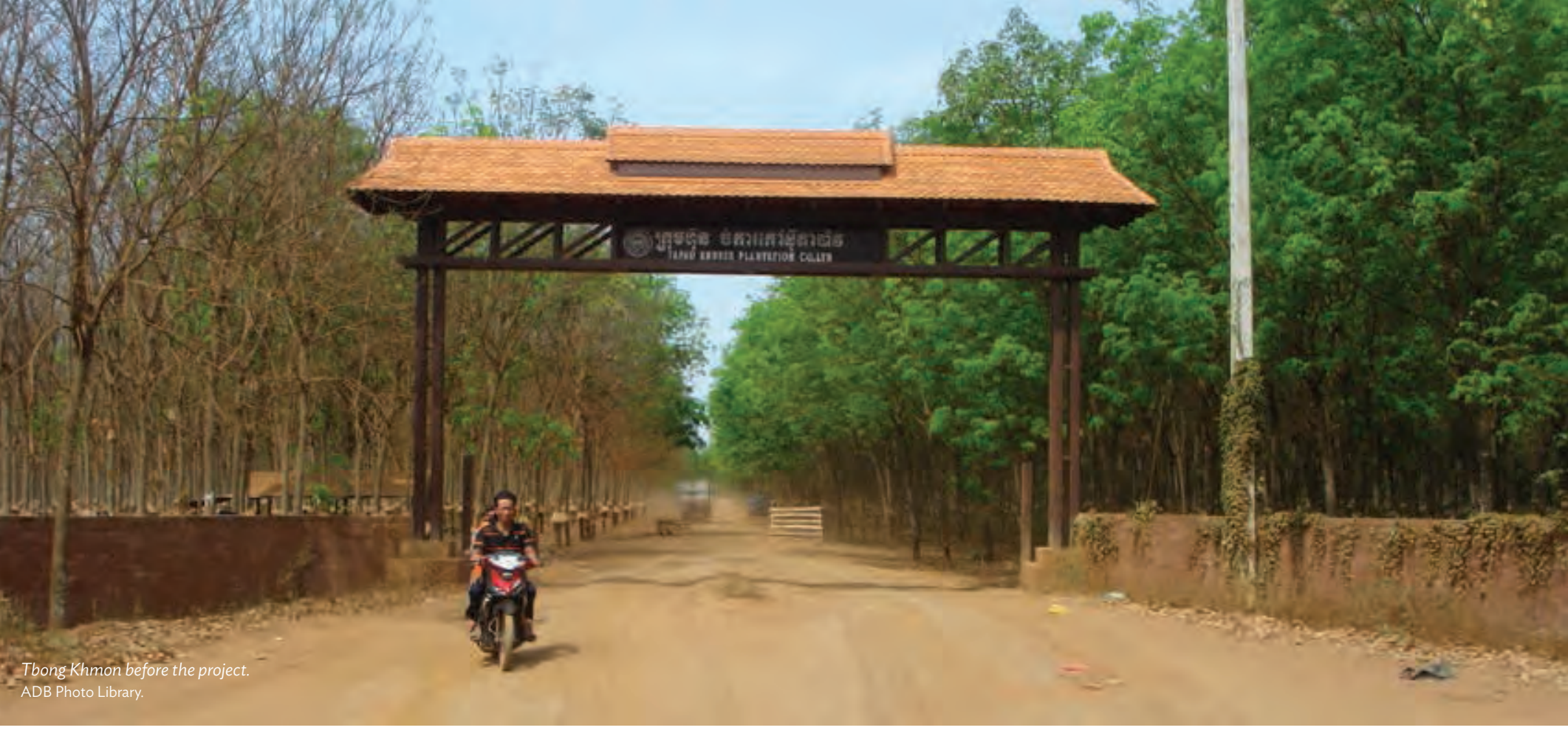

\section{SOLUTIONS}

ADB's Rural Roads Improvement Project targeted the improvement of rural roads in Cambodia, raising awareness on road safety, and mitigating social impacts of road development.

Pavement upgrade. About 545 kilometers of rural roads in the seven project provinces were paved using a double bituminous seal treatment, which waterproofs the pavements and provides an added layer of protection from daily wear and extreme weather conditions. Where floods are common, the embankments were raised. Permeable materials were used and culverts for cross drainage were installed to direct floodwater or rainwater into canals, rivers, or streams. During implementation, pipe culverts were provided for cross drainage. Drainage facilities for rural markets were constructed manually by community residents.

Climate change adaptation activities were conducted to improve planning for rural road infrastructure development and to increase the resilience of road infrastructure to climate change impacts. These initiatives involve mapping for rural roads' vulnerability, environmental and green planning, and planning water capture and storage systems. Climate monitoring systems, an early warning system, and emergency management planning have been developed and are being piloted.

The project benefitted from parallel cofinancing from the Government of the Republic of Korea through the Export-Import Bank of Korea, which financed part of the civil works and related consulting services. The Nordic Development Fund also provided parallel cofinancing for climate change adaptation interventions.

Road safety awareness and social impacts. Better roads induce increased vehicle speeds, and the newly paved rural roads posed tremendous safety risks to rural communities that were never exposed to such environment before. A community-based road safety awareness program was implemented to promote road safety practices among all road users and residents. The program involved road safety training and education for everyone in the project communities, from motorists, to school teachers, students, and parents, to local authorities. 


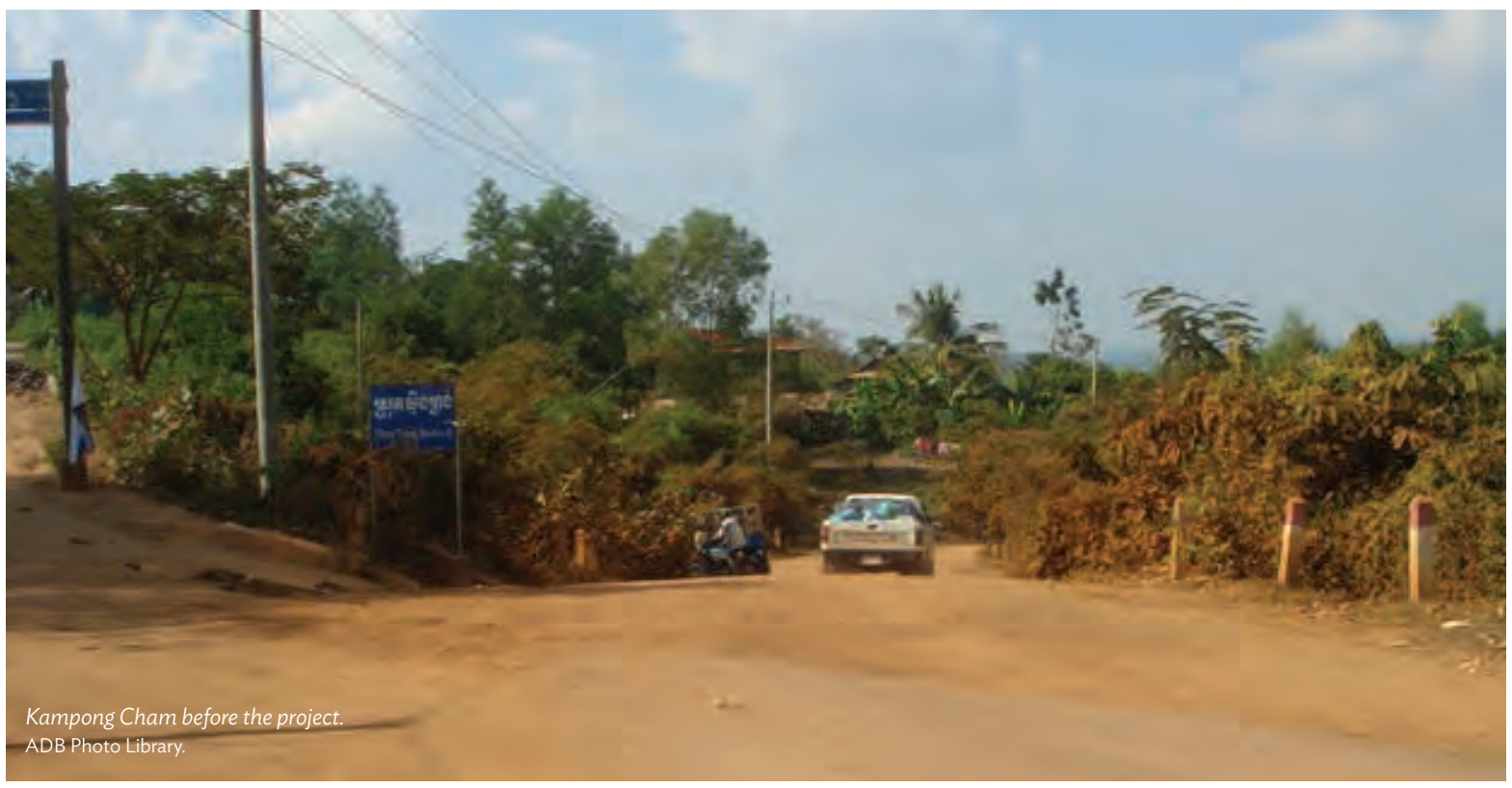

The road safety awareness program was delayed because of the lack of combined international and local expertise to make the program more effective. International and local road safety experts who were to facilitate the program had been difficult to find. Many international experts perceive road safety as a structural problem, with little understanding of road user behavior within specific social and cultural contexts. Local experts meanwhile lack the international experience. ADB missions had to work hard to transfer knowledge and build the capacity of local experts, community leaders, NGOs, and volunteers to form the critical mass needed to get the program off the ground.

The project likewise posed a potential increase in HIV/AIDS cases and human trafficking. With increased mobility, the opening of Cambodia's remote areas could increase the spread of HIV/AIDS, because of the greater influx of tourists and other outsiders. Trafficking of girls and women could increase, especially in areas that are near national roads and border areas. An HIV/AIDS and Human Trafficking Prevention Program was implemented to address these negative impacts.

A special feature of the project is its concern for gender issues. Road construction provided an opportunity for rural women to earn additional income by offering equal job opportunities ${ }^{2}$ to both women and men. In 2012, the Ministry of Rural Development established a Social and Environment Office, initially tasked to prepare progress reports on the project's built-in Labor and Gender Action Plan that ensured women of work opportunities for the project, with equal wages and other benefits to that of men workers. A sex-disaggregated baseline socioeconomic survey of project beneficiaries was also conducted for performance, monitoring, and evaluation purposes.

Improved road asset management. A road asset management approach used in another project ${ }^{3}$ was adopted. The Ministry of Rural Development issued an axle load control prakas (or policy) for

2 ADB contracted CARE, a humanitarian organization that places special focus on women, to work in some of the areas close to the road project to ensure that women are given equal access to jobs offered under the project. ADB. 2014. Cambodia Road Project Empowers Women. http://www.adb.org/features/cambodia-road-project-empowers-women

3 ADB. 2009. Report and Recommendation of the President to the Board of Directors: Proposed Loan to the Kingdom of Cambodia for the Road Asset Management Project. Manila. http://www.adb.org/projects/41123-013/main 


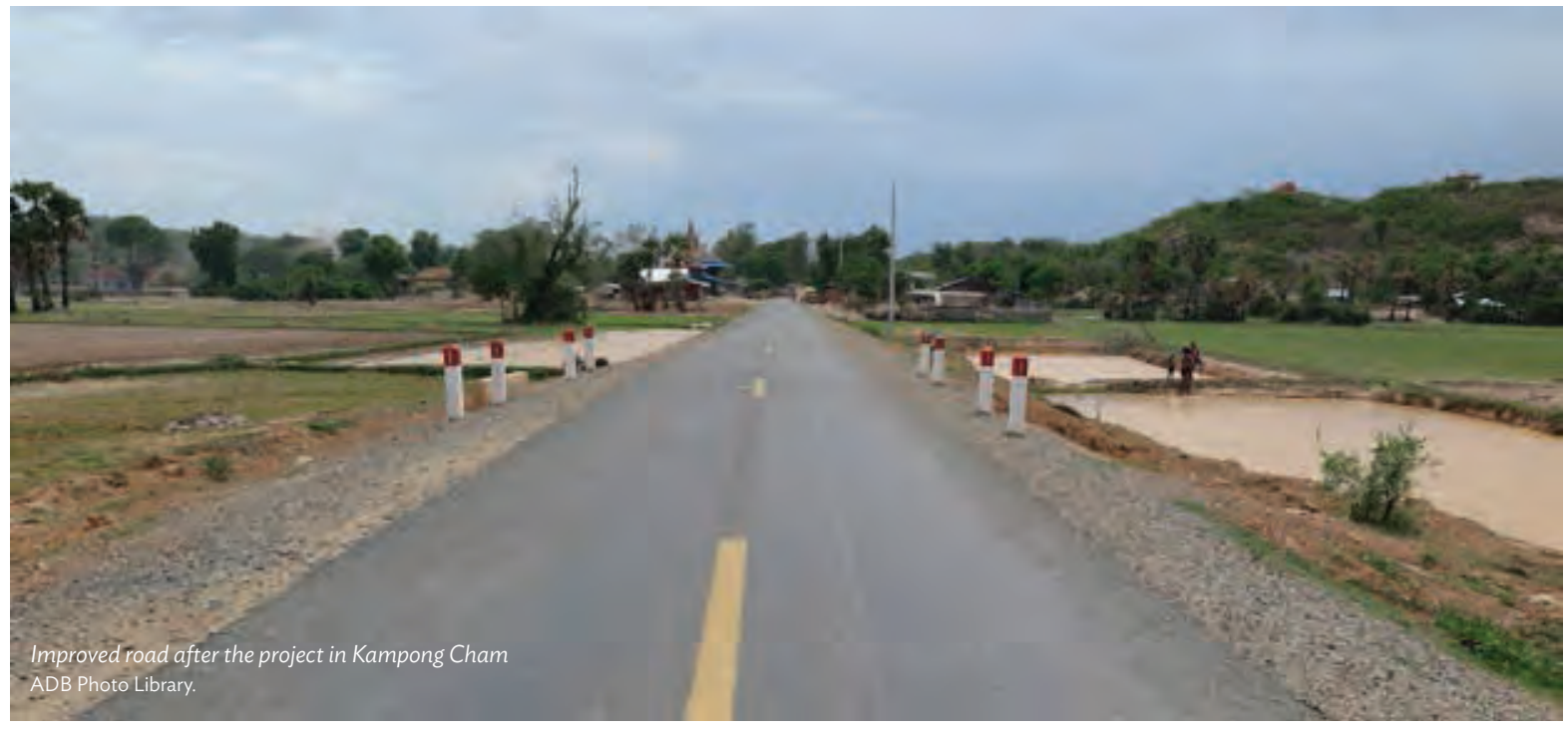

rural roads to prevent overloading, and organized an associated national workshop in September 2015. Equipment was procured and support facilities have been completed. Ministry staff and staff of its provincial offices have been trained to strengthen capacity in road asset management, including budget planning and road maintenance management.

A source of concern for future maintenance of the paved roads was allayed by the overloading prevention program for rural roads as well as routine and recurrent road maintenance. More than this, the project is also focusing on improving the overall construction industry for rural road maintenance through continuous training of road engineering professionals, in association with the Board of Engineers of Cambodia and Cambodia Contractors' Association. Professional engineering and contracting institutes are to be established to increase the capacity of local private sector contractors.

Better project management. The project also helped increase the capacity of the Ministry of Rural Development in project management and strengthened its ranks with new personnel assigned to provincial offices. A major achievement of the ministry is the design and planning, using the project's loan proceeds, of the Rural Roads Improvement Project II. This ongoing second project is pursuing similar objectives in a broader and expanded context, while already using the lessons learned in the implementation of the initial project.

\section{RESULTS}

By improving Cambodia's rural road network, ADB's Rural Roads Improvement Project has linked rural communities to urban centers while providing a safer road environment and increasing government capacity in implementing road development projects

Safe rural road environment. Road safety seminars were conducted for school teachers, youth groups, and parents. Workshops on improving the safety of bicycle, motorcycle, and slow-moving vehicles like the koyun (a tractor with two wheels) and horse-or ox-drawn carts were also conducted. In December 2015, the Ministry of Rural Development organized an International Road 
Safety Seminar in Siem Reap to disseminate project knowledge on rural road safety to key, national and international stakeholders.

Increased connectivity. With the newly paved roads, the slow rustic life in Cambodia's rural areas have gathered some speed. Transporting agricultural products from farm to market has become faster. Services and facilities not available in rural areas such as banks, credit facilities, hospitals, markets, and schools can be reached easily and more conveniently. Some of the more direct beneficiaries of the upgraded roads are children and teachers whose schools are located far from their villages.

\section{LESSONS}

Lessons from ADB's Rural Roads Improvement Project have been incorporated in the ongoing Rural Roads Improvement Project II. (see box).

Understand road user behavior to develop effective road safety measures. Statistics on major causes of road crashes in rural roads reveal that user behavior is a key factor. The community road safety and awareness program was designed to provide long-term solutions to reduce road crashes, and this involves a general change in attitude and behavior of road users, particularly in adopting good road safety practices. Many people in Cambodia's rural communities are experiencing paved roads for the first time, particularly children.

Improving road safety requires more than just structural interventions. Ensuring long-term road safety requires an in-depth understanding of road user behavior within specific social and cultural contexts. A good mix of international and local road safety expertise is needed to facilitate more effective road safety programs. Continuous road safety education is required to change road user behavior to achieve safer road environments.

Use loan proceeds to plan and design follow-on projects. The use of loan proceeds to finance the subsequent Rural Roads Improvement Project II is a wise use of funds and allows greater project ownership. It also provides the Ministry of Rural Development opportunities to correct the imperfections of the previous project. Similarly, the ongoing Rural Roads Improvement Project II has allocated loan proceeds to design another project, the Rural Roads Improvement Project III, that is likely to be approved in 2018.

Build a strong and committed project team. ADB is the first development agency to finance rural road development in Cambodia in a large-scale intervention. The project was met with much enthusiasm, not only from potential beneficiaries but also from the eager staff of the Ministry of Rural Development. In 2009, when the projects were still in the planning stages, ADB and the ministry began a close working relationship that was nurtured, in part, by mutual assurances from both parties.

ADB missions worked hard to find the right mix of experts, community leaders, NGOs, and volunteers, to form the critical mass needed to get the various aspects of the project off the ground. Road construction was completed ahead of time and within budget, with scope to enhance the development objectives for a future similar project. 


\section{Keywords:}

rural roads, road asset management, road safety awareness, road rehabilitation, co-financing, climate change, land transport, Rural Roads Improvement Project, Cambodia

\section{For further reading:}

- Project web page: Rural Roads Improvement Project: http://www.adb.org/projects/42334-013/ main

- Project web page: Rural Roads Improvement Project II: http://www.adb.org/projects/42334-014/ main

\section{For further information:}

- Shihiru Date, Senior Transport Specialist, Southeast Asia Department | sdate@adb.org

- Tyrrell Duncan, Technical Advisor (Transport), Sustainable Development and Climate Change Department|tduncan@adb.org

- Ki-Joon Kim, Principal Transport Specialist, Sustainable Development and Climate Change Department|kjkim@adb.org

- Dongxiang Li, Lead Regional Cooperation and Integration Specialist, Economic Research and Regional Cooperation Department | dongxiangli@adb.org

\section{Building on Past Lessons: The Rural Roads Improvement Project II}

As Cambodia's rural roads are being paved through the Rural Roads Improvement Project, ADB approved another loan in 2014, amounting to $\$ 54$ million, to rehabilitate a further 1,200 kilometers of rural roads.

The Rural Roads Improvement Project II (Rural Roads II) targets rural road improvements in the seven provinces of the first project (Battambang, Kampong Cham, Kampong Chhnang, Kampong Speu, Kampong Thom, Pursat, and Siem Reap), and three additional provinces, Banteay Meanchey, Takeo, and Thbom Khmom. It also includes paving about 50 kilometers of rural roads and 11 jetties in a five-island cluster in the Mekong River. Rural Roads II improves upon the preceding project's road construction initiatives and is expected to be completed in 2020.

Climate change-resilient infrastructure. As in the preceding project, Rural Roads II uses double bituminous seal treatment in road construction for increased protection against daily wear and floods. To improve climate change resilience, the project is increasing embankment heights, providing cross drainage, and selecting more permeable embankment materials. Green planting has been adopted to strengthen embankments exposed to higher risk of flood damage. Pipe culverts, discovered to be inadequate to drain rainwater during the implementation of the preceding project, are being replaced and widened.

In the Mekong River islands, isolated communities, with a total population of about 30,000, are vulnerable to floods during the rainy season, cutting them off from markets and public services. 
The lack of mobility and connectivity during natural disasters and other emergencies often result in not only the loss of lives but also of agricultural crops and livestock. Through Rural Roads II, climate change adaptation aspects of road construction of the previous project have been replicated in the rehabilitation of roads and jetties that service these island communities. Hazard maps were used, with rainfall data and benchmarks applied in infrastructure design to provide year-round all-weather access. Plans for emergency management have also been set up to prevent further losses. The project is also implementing multi-sector activities to bring inclusive growth in the islands.

Cofinancing for better project outcomes. Rural Roads II, with its larger coverage, needed more funding, prompting the government to seek financial assistance from more donor agencies. Careful preparations for cofinancing arrangements were undertaken, including considering ways on how to allocate and optimize development partners' funds to achieve best outcomes. Compliance with the requirements of cofinancing partners in project design, approval process, requirements, milestones, and implementation requirements, including communication and monitoring requirements, were ensured.

The Government of Australia has provided grant cofinancing for rural road improvements, rural road asset management, rural road safety, and community awareness program. The ExportImport Bank of Korea is also helping to finance rural road improvements, while the Nordic Development Fund is providing grant cofinancing for the civil works for green planting and consulting services for climate change adaptation, under the connectivity improvements for the Mekong River islands output. The Agence Française de Développement and the Strategic Climate Fund are providing additional financing for road rehabilitation and overall expansion of the project's scope.

Building on past lessons. Rural Roads II is a very good example of deliberate and purposeful use of lessons learned from a previous project to improve present and future interventions. The project has allocated loan proceeds to design a third project to further improve Cambodia's rural road network.

\section{References:}

- Project web page: https:/www.adb.org/projects/42334-014/main.

- ADB. 2014. Report and Recommendation of the President to the Board of Directors: Proposed Loan and Administration of Grants to the Kingdom of Cambodia for the Rural Roads Improvement Project II. Manila. https://www.adb.org/sites/default/files/projectdocument/81740/42334-014-rrp.pdf.

\section{Contact:}

Shihiru Date, Senior Transport Specialist, Southeast Asia Department | sdate@adb.org 


\section{CONTEXT}

\section{$\mathrm{n}$ the states of Chhattisgarh and Madhya Pradesh in India, the struggle against poverty is made more difficult by the lack of \\ paved and durable roads. Disconnected from markets, schools,} hospitals, and other modern amenities, the rural poor are missing out on higher incomes, more job opportunities, and better social services being enjoyed by people in urban centers. About $70 \%$ of the people in India live in rural areas and about $40 \%$ of rural habitations are not

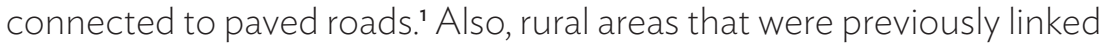
by paved roads have lost their connectivity due to low standards in road maintenance. Many rural roads need to be improved and rehabilitated in the two poorest states in the country.

Rural roads represent $80 \%$ of India's extensive road network and carry $20 \%$ of road traffic. In Chhattisgarh and Madhya Pradesh, where large rural populations are widely dispersed, the lack of rural connectivity is one of the major causes of poverty. ${ }^{2}$ Chhattisgarh has a total of 15,000 kilometers of rural roads; Madhya Pradesh has about 159,530 kilometers.

In 2000, the Government of India launched the Pradhan Mantri Gram Sadak Yojana or the Prime Minister's Rural Roads Program, a national initiative that aims to provide road connections to habitations with a population of 1,000 or more by the year 2003 and to habitations with a population of 500 or more by 2007 . The total program cost from 2002 to 2007 was about Rs550 billion (about $\$ 11$ billion equivalent). The government requested $\mathrm{ADB}$ to finance part of the program.
PROJECT SNAPSHOT

India: Rural Road Sector I Project

Approval date:

NOVEMBER 2003

Amount:

\$400 MILLION LOAN

Borrower:

GOVERNMENT OF INDIA

Executing agency: Ministries OF RURAL Development of THE STATE GOVERNMENTS OF MADHYA Pradesh and ChHATtisgarh

Geographical location: STATES OF CHHATTISGARH AND MADHYA PRADESH, INDIA

Transport project: ROAD (NON-URBAN)

Completion date: JUNE 2009

In support of the program, ADB approved the Rural Road Sector I Project in 2003. The project rehabilitated 11,000 kilometers of roads and provided all-weather road connections to about 1,900 rural habitations. The project also improved the efficiency and sustainability of the program by providing support for capacity building and research and development. Support for developing financing and implementation arrangements for road safety and maintenance were also provided.

The project was completed in 2009.

\section{SOLUTIONS}

ADB's Rural Road Sector I Project, supported by the Prime Minister's Rural Roads Program, rehabilitated rural roads in Chhattisgarh and Madhya Pradesh and improved the capacity of local government and national government agencies in road maintenance and asset management.

1 A habitation is a cluster of houses and one village may have more than one habitation. ADB. 2003. Report and Recommendation of the President o the Board of Directors: Proposed Loan to India for the Rural Roads Sector I Project. Manila.

2 Road connectivity in rural areas is considered a prime catalyst to poverty reduction. Public expenditure on rural roads in India had greater poverty reduction impact than expenditure on agricultural research, irrigation, power, education, health, and soil and water conservation, and existing antipoverty programs. ADB. 2003. Report and Recommendation of the President to the Board of Directors: Proposed Loan to India for the Rural Roads Sector I Project. Manila. 
Civil works were implemented in four batches. The first batch had a total road length of 834.68 kilometers, the second had 2,758.57 kilometers, the third had 3,906.27 kilometers, and the fourth had $2,075.00$ kilometers. The roads in the first batch were selected during project preparation as sample subprojects.

Despite the spread of civil works over time, the number of construction projects overburdened the local construction industry and caused some delay. Experienced contractors willing to take on rural road projects became scarce. Contractors for the civil works in Chhattisgarh and Madhya Pradesh could not keep up with the work volume of road construction initiated by the project. Unfavorable weather conditions and flooding contributed to delays in road construction. Nevertheless, the project constructed a total of 9,574.7 kilometers of rural roads.

Construction materials, especially cement, steel, and asphalt, became scarce and expensive, especially for the construction of the second and third batches of rural roads. Machinery and equipment became unavailable. Contractors had to slow down civil works while waiting for the cost of construction materials to go down. Overwhelmed, some contractors performed poorly, while others were unable to finish civil works. There was no price escalation clause in the civil works contract. The national government provides no funds for price escalation, and any price increase for construction is to be borne by the states. The civil works contracts included a provision that required contractors to provide 5 years of postconstruction maintenance.

Improved institutions for better road maintenance and asset management. After the 5-year road maintenance required of contractors, the state rural roads development agencies are to take on road maintenance responsibilities until such time that the panchayats are capable. In the meantime, the state agencies and panchayats, with support from the project, established the procedures, financing arrangements, and institutional capacity to ensure the sustainability of road assets created under the program. They established road maintenance budgeting, planning, and management systems; and developed standard performance-based contracts for road maintenance.

Support for capacity building and on-the-job training was also provided to the state agencies. The project also financed the procurement of vehicles and equipment needed for managing road maintenance. Road safety audit and community road safety programs were developed and introduced, targeting road users living in the project road areas of influence. Manuals on road maintenance and road safety were also targeted as part of project consultancy work, but did not push through because of the consultant's lack of expertise.

State governments, at the policy dialogue during project preparation, were required and committed to provide annual financing for sustainable rural road maintenance. Madhya Pradesh earmarked the mandi cess, a tax on agricultural markets; Chhattisgarh, which enjoys large state revenues from mining, committed a part of the state government budget.

\section{RESULTS}

By rehabilitating rural roads, ADB's Rural Road Sector I Project increased connectivity among rural communities and improved their access to better public services and more economic opportunities.

Improved rural connectivity. The project connected a total of 3,207 habitations, of which 1,551 were in Madhya Pradesh and 1,656 were in Chhattisgarh. Also, 1,222 habitations with populations below 
500 were also connected. Despite the shortfall in the intended road length, the project surpassed the original target of 1,900 connected habitations, benefitting 11 million people (footnote 4).

Buses, jeeps, vans, and three-wheelers now provide reliable public transportation for newly connected villages to and from nearby towns and cities. Private ownership of motorized and nonmotorized vehicles in project habitations have also increased. Most notably, there has been a large increase in the number of motorcycles: 17\% in Chhattisgarh and 35\% in Madhya Pradesh. While there has been a decrease in the number of bicycles, they remain the primary mode of transportation for students to reach school. The number of bullock carts is still increasing, although at a slower rate.

The average vehicle operating speed was twice as high on the project roads. Average travel time to the nearest town decreased by 36 minutes in Madhya Pradesh and 14 minutes in Chhattisgarh. For example, in the village of Chhantajha in Kawardha District of Chhattisgarh, villagers reported that the travel time to the nearest town 7 kilometers away was from 1 hour to 3 hours by bicycle during the rainy season. Now, the same trip takes 15 minutes to 20 minutes by motorcycle or 30 minutes by bicycle (footnote 4).

For people outside of the village, the rural roads allow government workers, including health workers, teachers, and agriculture extension workers, easier access to the habitations in order to provide services and information to rural communities. The roads also promote a higher level of social interactions between villagers and external residents.

Better services and opportunities for rural communities. Once-isolated rural villages are now connected to markets, hospitals, schools, and other centers of economic activity by all-weather roads leading to overall socioeconomic development. A preliminary study suggests that, between 2006 and 2008, the number of households living below the poverty line in project villages in Chhattisgarh decreased by $2 \%$; in Madhya Pradesh, the decrease was at $5 \%$.

More reliable transportation has encouraged parents in rural communities across the two states to be more willing to send their children, especially their daughters, to schools and colleges in neighboring towns. Enrollment has spiked. Bus fares have been reduced by about $11 \%$ since vehicle operating costs have decreased. Private bus services for farmers' children are now available and absenteeism among both students and teachers, which was high especially during the rainy season when roads were unsuitable for motorized traffic, is now at an all-time low.

Smoother and faster travel led to higher incomes of farmers who were able to bring and sell more produce at the market. Market interaction has also brought modern cropping techniques. Farmers now produce other crops besides wheat, such as soya, pulses, and sugar cane.

Rural healthcare has also improved because of the new roads. Children gained access to vaccines; severely malnourished infants were provided with supplements; and pregnant women were supplied with iron and vitamins. Children's health has improved and deaths in birth delivery have been reduced. 


\section{LESSONS}

The Rural Road Sector I Project was ADB's first project that supported the Prime Minister's Rural Roads Program. Lessons from the project have been adopted in similar subsequent projects, particularly the Rural Roads Sector II Investment Program and the Rural Connectivity Investment Program.

Strengthen postconstruction maintenance. With panchayats gearing up to take a more active role in managing road maintenance activities, it would be useful to develop guidelines for postconstruction maintenance once contractors hand over the responsibilities. ADB has helped improve the revised contract of the consultant tasked to develop the road safety and a road maintenance manual for the project. Following up on the development of such a manual would help panchayats take over road maintenance responsibilities.

Involve the community in road maintenance. As mandated by the Prime Minister's Rural Roads Program, communities are more directly involved in the project through the panchayats. By delegating postconstruction maintenance to contractors for 5 years, the state rural roads development agencies and panchayats have the time to build technical expertise and financial capability for road maintenance functions.

\section{Keywords:}

Rural road, rural connectivity, poverty, Pradhan Mantri Gram Sadak Yojana, Prime Minister's Rural Roads Program, Rural Road Sector I Project, land transport, India

\section{For further reading:}

- Project web page: http://www.adb.org/projects/36320-013/main

- Roads Connect Villages to Opportunity in Central India: http://www.adb.org/results/roadsconnect-villages-opportunity-central-india

\section{For further information:}

- Andri Heriawan, Transport Specialist, South Asia Department | aheriawan@adb.org

- Hiroaki Yamaguchi, Director, Transport and Communications Division, South Asia Department | hyamaguchi@adb.org

- Tyrrell Duncan, Technical Advisor (Transport), Sustainable Development and Climate Change Department |tduncaan@adb.org

- Ki-Joon Kim, Principal Transport Specialist, Sustainable Development and Climate Change Department|kjkim@adb.org

- Dongxiang Li, Lead Regional Cooperation and Integration Specialist, Economic Research and Regional Cooperation Department | dongxiangli@adb.org 

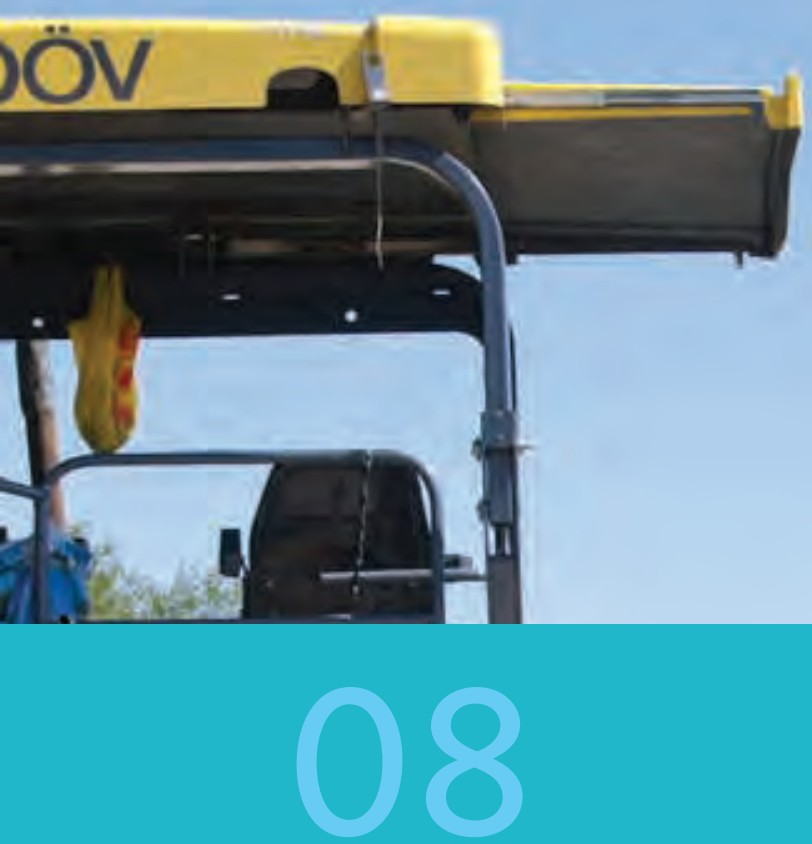

\section{ROAD MAINTENANCE}

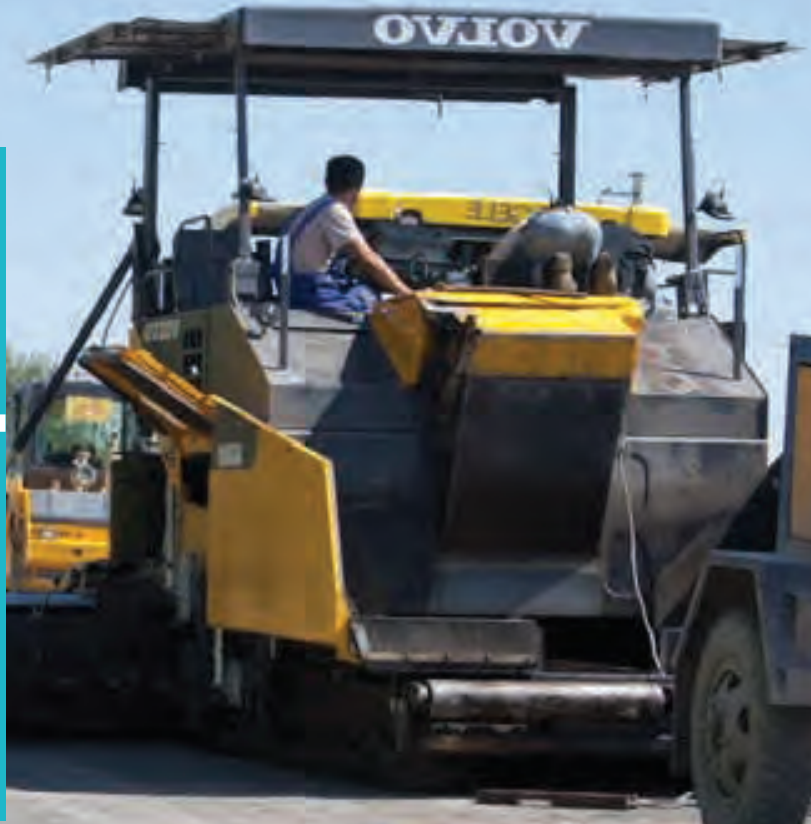

4

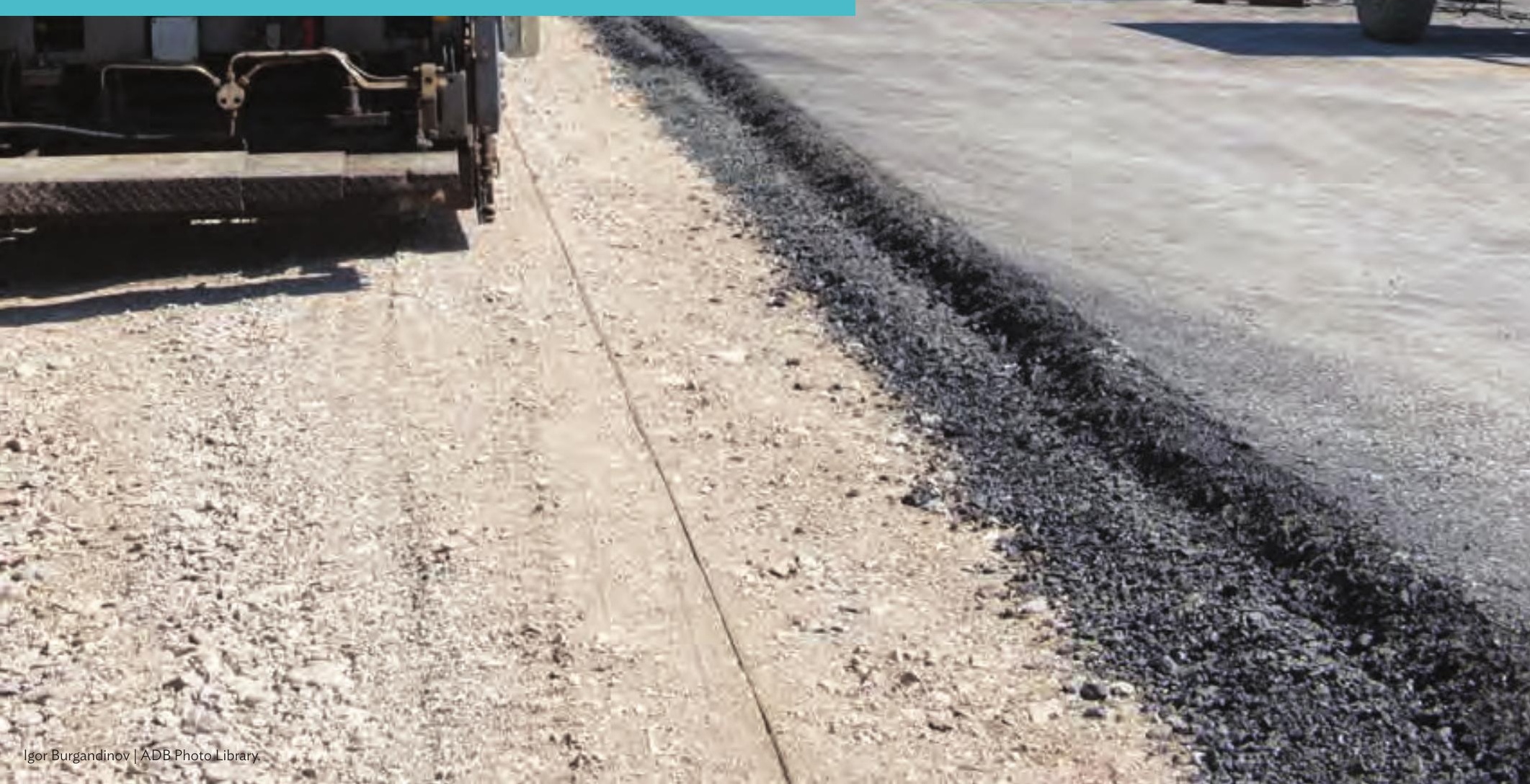




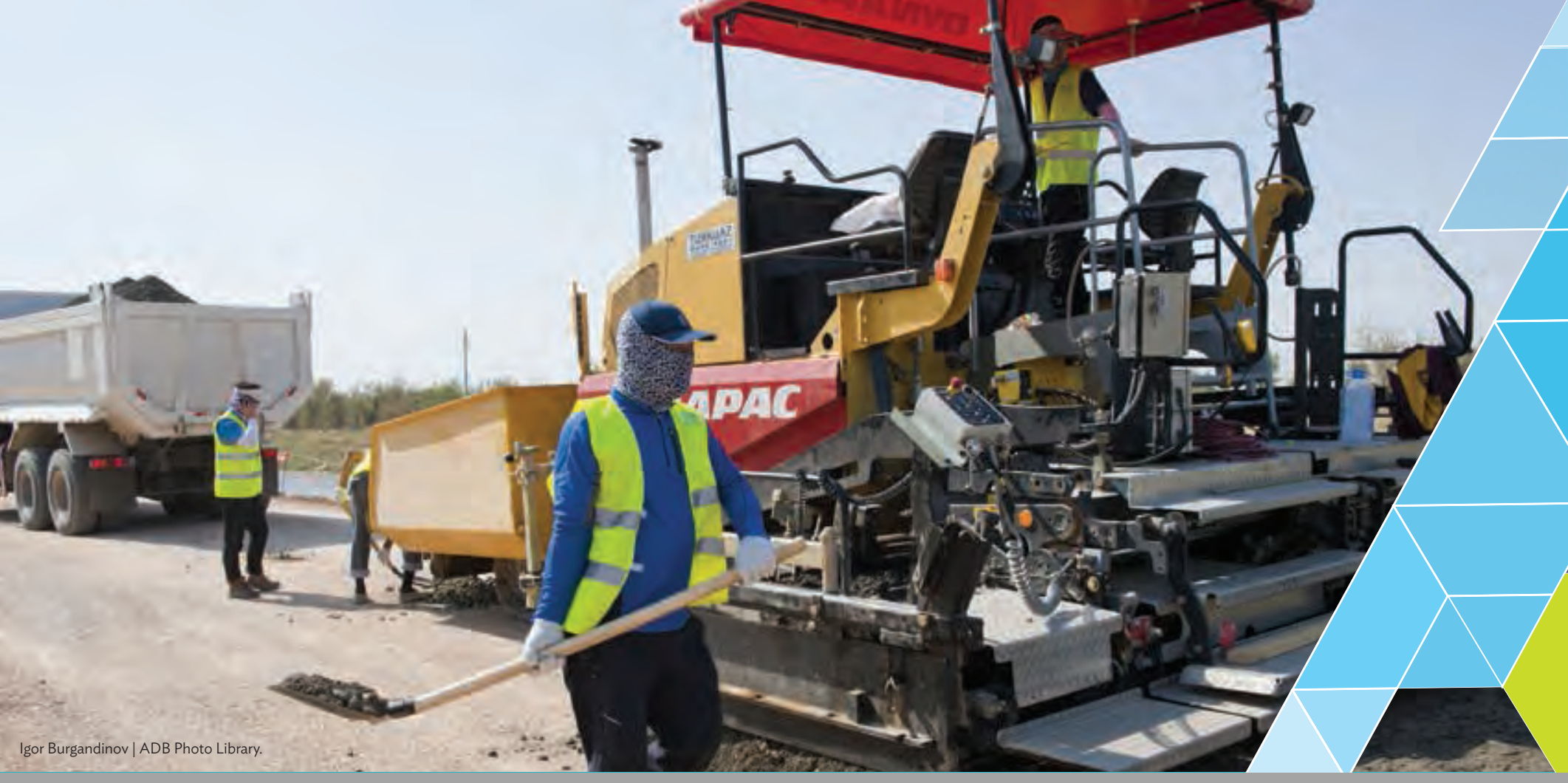

\section{CARE, Caution, and CONNeCtivity:}

\section{PARTICIPATORY PROCESSES IN ROAD IMPROVEMENTS IN BANGLADESH}

Bangladesh's road network is prone to damage and deterioration, and may not keep up with increasing traffic and road accidents. Rural communities in the northern regions need better links to the road network to access economic opportunities.

ADB's Road Network Improvement and Maintenance Project improved the road network by increasing the connectivity of rural poor areas, initiated road safety measures and activities to reduce backlogged road maintenance tasks, and helped ensure long-term financing for road maintenance.

With better and safer roads, rural communities in the northern regions of Rangpur and Mymensingh have improved connectivity to markets and commercial areas.

The project leveraged on participatory processes in selecting project roads, and recommends formulating a long-term action plan for road maintenance. 


\section{CONTEXT}

\section{n the northern Rangpur and Mymensingh regions of Bangladesh,' roads that link rural communities to national and regional highways are in poor condition. These "feeder" roads have been} limiting rural communities' access to markets, education, and public facilities in commercial centers. Other roads in good condition face a daily onslaught of vehicles carrying heavy loads of passengers or freight. They also witness several vehicular accidents every day. The roads are prone to damage and deterioration and may not keep up with the daily assault. Bangladesh needs to take better care of its roads and curtail road accidents, while improving the connectivity of its road network to link the rural poor to more economic opportunities.

Bangladesh's road network has grown over the last two decades, steadily expanding to cope with the rapid increase in demand for road transport. Primary roads are managed by the Roads and Highways Department within the Ministry of Road Transport and Bridges. Secondary roads, including rural and minor feeder roads, are managed by the Local Government Engineering Department within the Local Government Division. Road condition, capacity, and network reach have substantially improved, ${ }^{2}$ due mainly to international financing from major aid agencies, totaling $\$ 1.8$ billion. ADB, since 1977, has provided 12 loans totaling $\$ 931$ million. These coordinated efforts contributed considerably to meeting the growing demand for roads.

\section{PROJECT SNAPSHOT}

Bangladesh: Road Network Improvement and Maintenance Project

Approval date:

OCTOBER 2002

Amount:

SDR48,964,000 LOAN

(\$65 MILLION EQUIVALENT)

Borrower:

GOVERNMENT OF BANGLADESH

Executing agency:

ROADS AND HIGHWAYS

DePARTMENT, Ministry OF ROAD TRANSPORT AND BRIDGES

Geographical location: NORTHWESTERN AND NORTHCENTRAL REGIONS, BANGLADESH

Transport project: ROAD (NON-URBAN)

Completion date: DECEMBER 2011

The road sector's steady growth, however, is constantly threatened by insufficient resources for road maintenance and frequent road accidents. In the late 1990s, the allocation for routine and periodic road maintenance of primary roads decreased annually, while road fatality rate has been the highest in South Asia. ${ }^{3}$ Accidents are mainly due to speeding, overloading, and overtaking by motor vehicles. Road traffic is made more complicated by the free and uncontrolled movement of animal-drawn carts and a lot of slow-moving vehicles. Other road sector problems are lack of proper driver education, inefficient enforcement of traffic laws, nonpractice of regular vehicle maintenance by motor vehicle owners, and poor roads alignment and geometry at many places.

In 2002, ADB approved the Road Network Improvement and Maintenance Project to assist the Government of Bangladesh in improving transport efficiency and strengthening integrated road networks. The project improved a total of 152 kilometers of regional and feeder roads in Rangpur and Mymensingh initiated road safety measures and activities to reduce backlogged road maintenance tasks, and helped ensure long-term financing for road maintenance.

1 The project areas - the northwestern region of Rangpur and the northcentral region of Mymensingh — while being the poorest in Bangladesh, have the highest potential for delivering national and regional economic development. ADB. 2013. Completion Report: Road Network Improvement and Maintenance Project in Bangladesh. Manila.

2 ADB. 2002. Report and Recommendation of the President to the Board of Directors: Proposed Loan to the People's Republic of Bangladesh for the Road Network Improvement and Maintenance Project. Manila.

3 The number of persons reported killed increased from 955 in 1983 to 3,162 in 1997. ADB. 2002. Report and Recommendation of the President to the Board of Directors: Proposed Loan to the People's Republic of Bangladesh for the Road Network Improvement and Maintenance Project. Manila. 


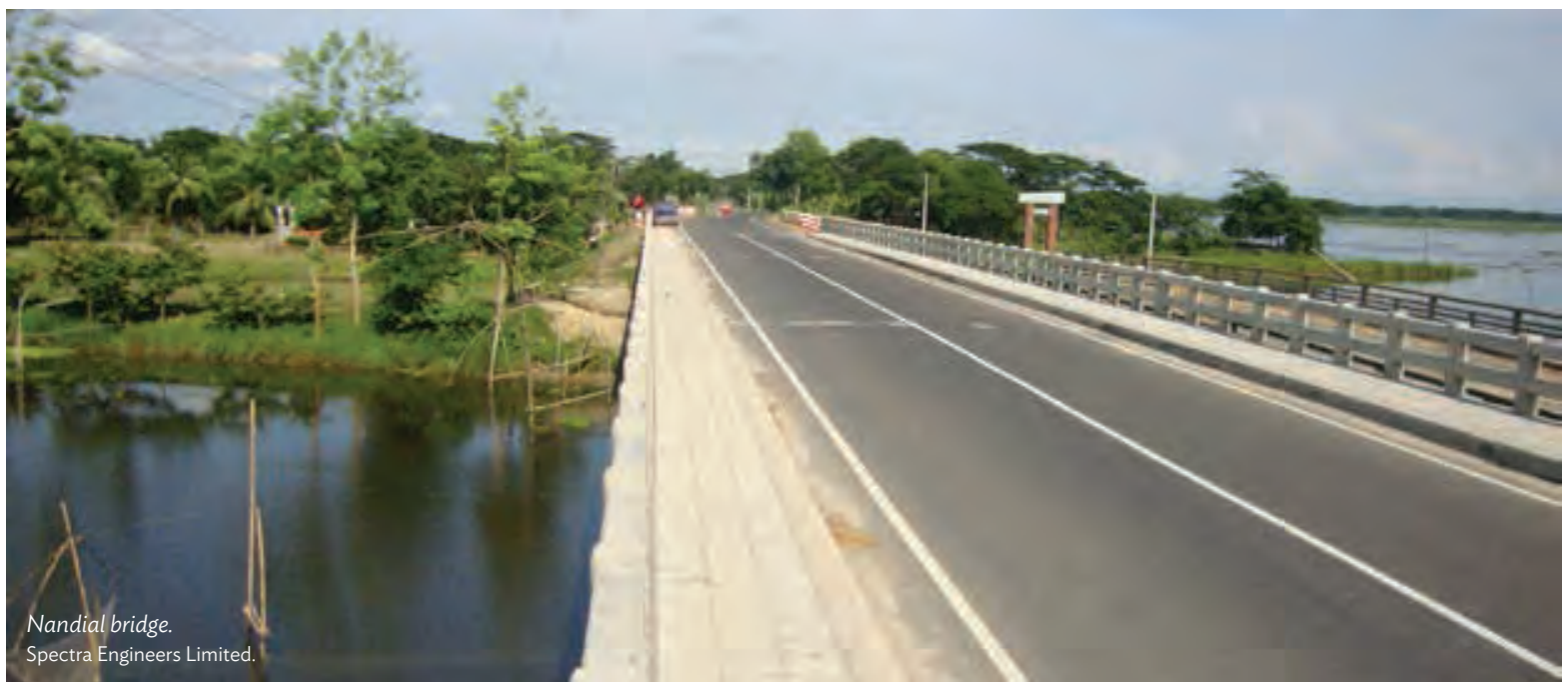

The project was completed in December 2011.

\section{SOLUTIONS}

Extensive participatory processes were conducted in selecting the project roads for ADB's Road Network Improvement and Maintenance Project. Relevant laws and policies were formulated and enacted to support the project, including for improving road safety and road maintenance.

Participatory road selection. The project fully reconstructed 48 kilometers of the regional Mymensingh-Nandail road and about 104 kilometers of feeder roads: Jamalpur-Dewanganj (25 kilometers), Muktagacha-Chechua (7 kilometers), Mithapukur-Madhyapara (24 kilometers), Thakurgaon-Ranisankail (36 kilometers), and Saidpur-Parbatipur (12 kilometers). ${ }_{4}^{4}$ The roads were also widened and substandard curves corrected. Nine bridges were also rehabilitated.

Selecting the roads that would effectively link rural farmers and communities to markets and economic opportunities was a crucial part of project planning. A feasibility study 5 assessed 27 roads in Rangpur and Mymensingh, following criteria that was established through extensive consultations with various stakeholders, including government officials, road engineers, NGOs, transport operators, public representatives, and common road users. The criteria included social aspects such as population density and literacy level, economic aspects such as unemployment level and income sources, road condition and traffic such as roughness and road use by nonmotorized vehicles, level of completion of road network loop, and stakeholders' recommendation.

Of the 27 roads, 17 were deemed technically and economically viable. From the 17 roads, 6 were selected as the project roads based on their potential contribution to economic growth, as well as likely poverty impact, adverse environmental impact, and social and resettlement implications.

4 ADB. 2013. Completion Report: Road Network Improvement and Maintenance Project in Bangladesh. Manila.

5 ADB. 2002. Technical Assistance to the People's Republic of Bangladesh for the Road Network Improvement and Maintenance. Project. Manila. 


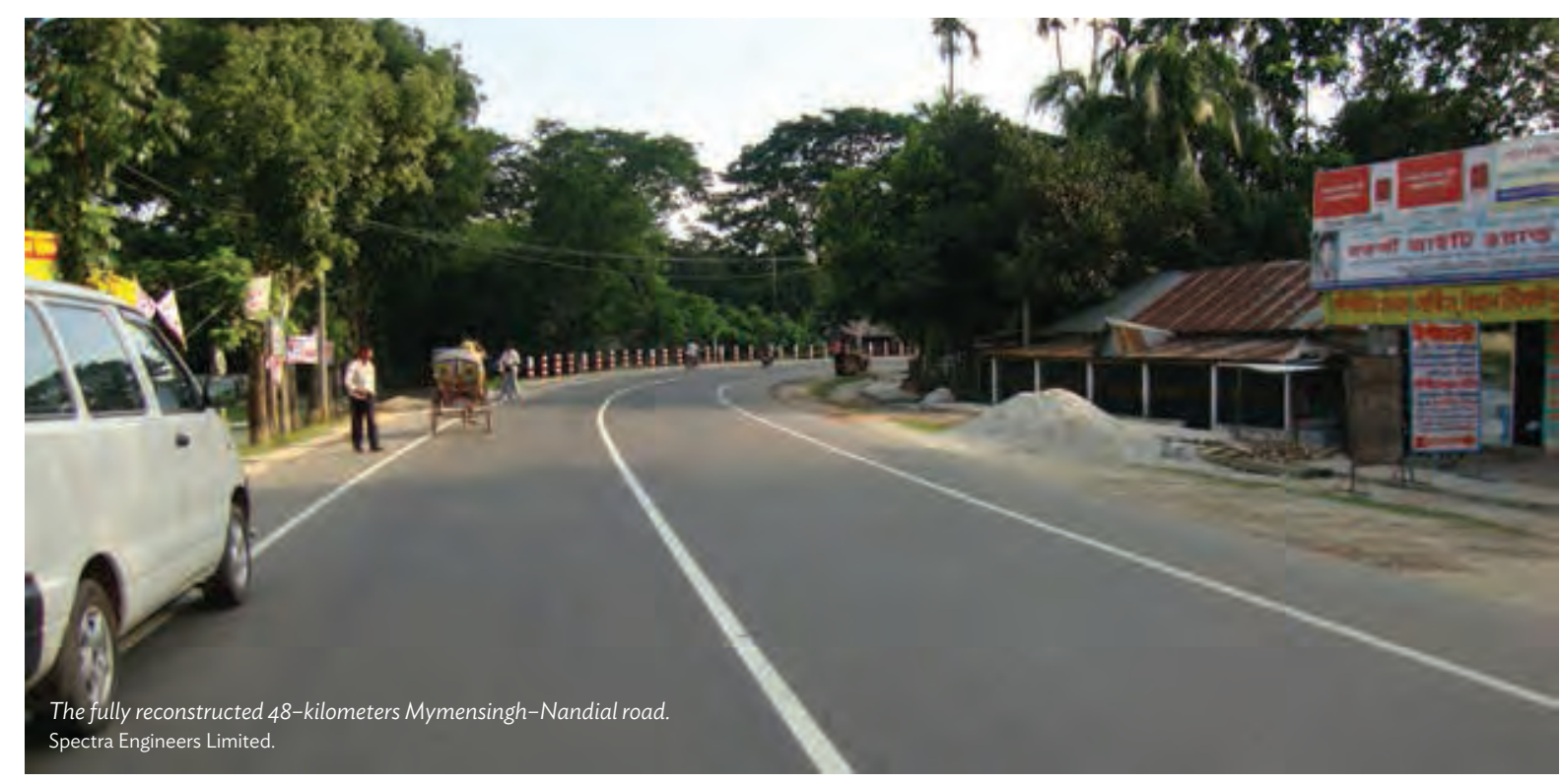

Investments in road maintenance and road safety. To jumpstart the government's initiative to focus on road maintenance, the project conducted periodic road maintenance of select roads. The roads were chosen using the highway design and maintenance standards model in the Annual Road Maintenance Plan. Civil works for road maintenance began in 2006 and completed in August 2010. A total of 391 kilometers of roads underwent periodic maintenance in the project areas.

A performance-based contract for a 3-5 year period was used to introduce efficient practices in routine road maintenance works. This covered 50.5 kilometers of roads in the project area. These were completed in June 2011.

The project installed axle load control stations to protect roads from wear, and addressed black spots or accident-prone areas along the project roads and other selected roads. An education and public awareness campaign for road users and pedestrians was also conducted as was a road safety audit to ensure compliance with road safety requirements. About 204 kilometers of roads were assessed for road safety. Both civil works and public awareness campaign were implemented from October 2010 to April 2011.

The project required a feasibility study on private sector investment for road maintenance activities, the results of which should be the basis of a time-bound action plan to be developed by the Roads and Highways Department. Although the department was unable to prepare an action plan, efficiency has been improved by the introduction of performance-based contracts and the outsourcing of maintenance works to several private sector owned and operated equipment rental companies, that have emerged since the project was approved.

Mechanisms to financially sustain road maintenance in the coming years are being put in place, including setting up a road maintenance fund using road-user charges. The Roads Fund Board, established through the Roads Fund Board Act, will manage the fund and ensure the efficient and transparent use of the maintenance budget. The government and ADB also agreed on a 10-year maintenance financing strategy that should also lead to a reduction in the maintenance backlog. 


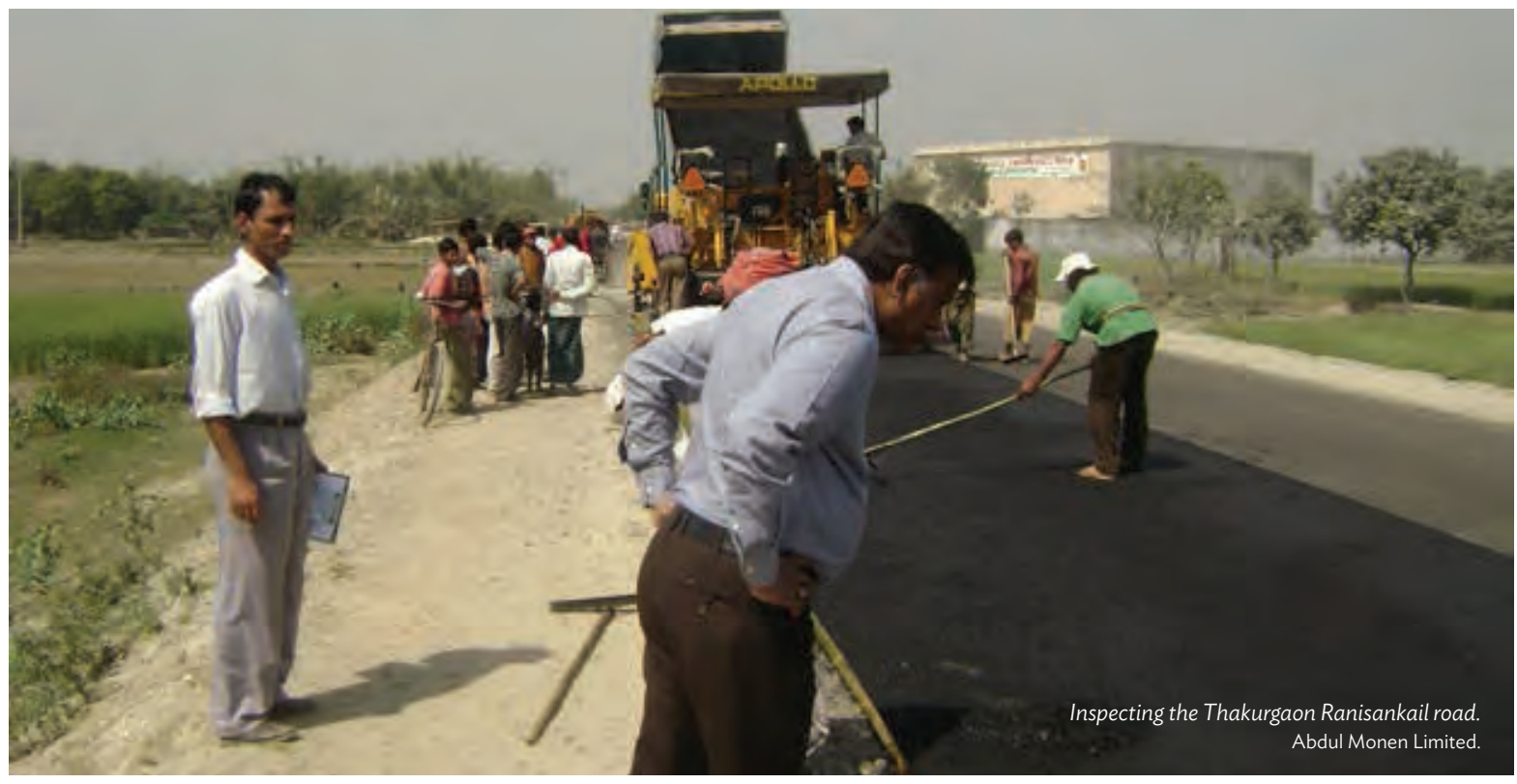

Firmed up policies and legislation. The Government of Bangladesh pursued the formulation and enactment of several laws and policies to support the project. The 1925 Highway Act was updated in 2001, and the 1984 Motor Vehicles Ordinance was amended in 2004. These legal instruments support the regulation of traffic movement throughout the country and help mitigate traffic congestion on major road networks.

The government also enacted the Roads Fund Board Act to set up a road maintenance fund, the source of its revenues; the composition and general duties of the Road Fund Board; and the preparation and review of the annual road maintenance program of road agencies. The law was passed in 2013. The 10-year maintenance financing strategy agreed upon by the government and ADB should also lead to reducing the maintenance backlog.

The Road Safety Cell under the Bangladesh Road Transport Authority developed a comprehensive highway code in 2009 that set out rules for road users, including guidelines for safe driving and illustrated guides for road safety education. The Road Safety Cell also acts as secretariat to the National Road Safety Council, which formulates road safety strategic action plans to support the government's initiative to improve road safety.

\section{RESULTS}

ADB's Road Network Improvement and Maintenance Project provided better and safer roads and improved connectivity among many rural communities in Bangladesh.

Better and safer roads. Traffic has increased on the completed project roads, which provided greater ease of movement of people and goods. Travel time to the nearest markets, health services, and schools has been reduced. The project has generated an increase in traffic on the completed project roads, with annual average daily traffic at 3,269 vehicles per day. Black spots along the project 


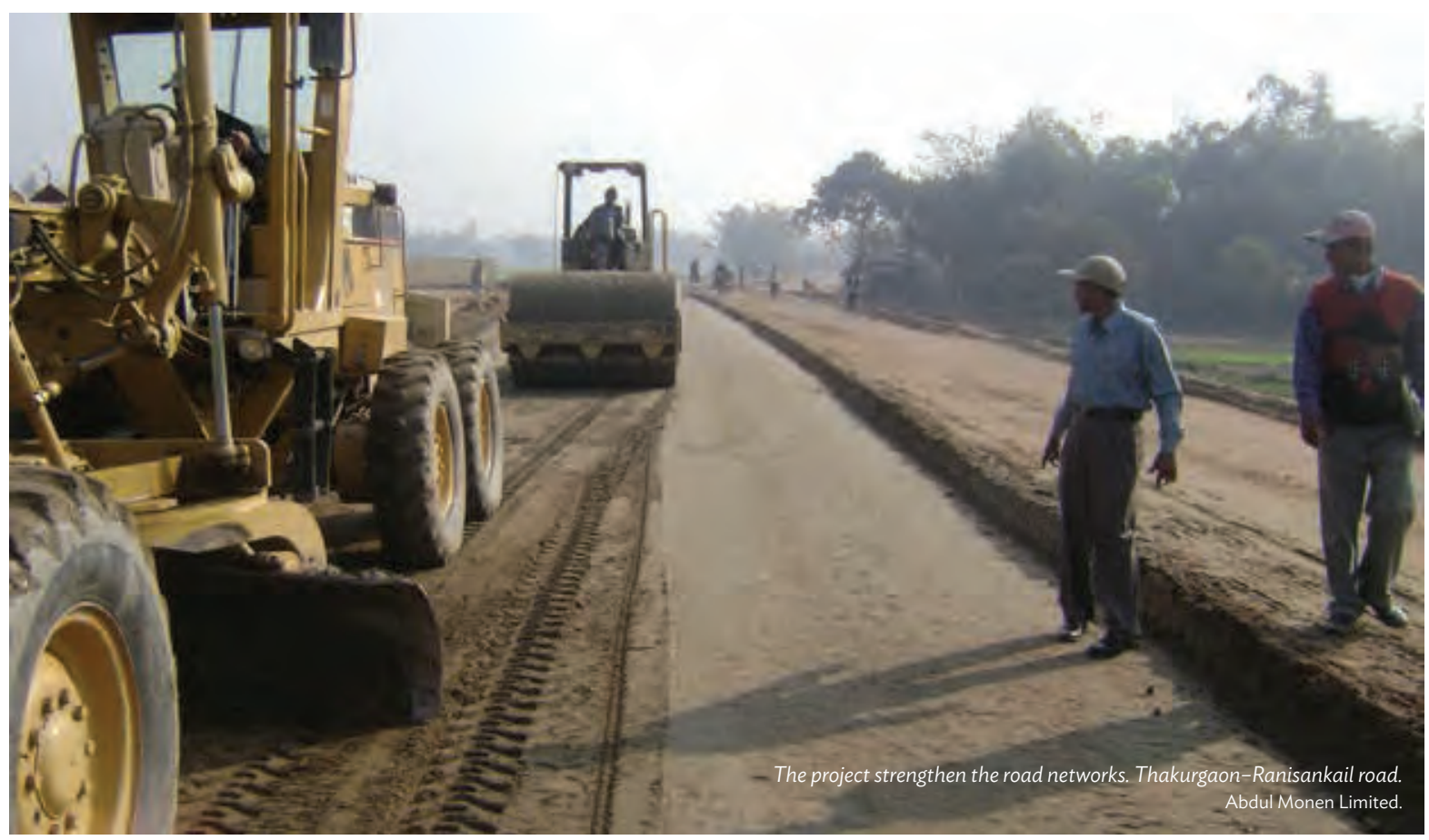

roads have also been improved. Three axle load control stations established by the government during 2010-2011, contribute to enhanced road safety. Riding qualities of the project roads have improved, while vehicle operating costs decreased by $20 \%$.

The government has also increased the road maintenance budget. The allocation for routine road maintenance increased from Tk741 million in 2007 to Tk2,700 million in 2012, and for periodic maintenance from Tk1.7 billion in 2007 to Tk4.o billion in 2012.

Increased connectivity. With easy access to markets and other economic opportunities, rural communities in northern Bangladesh have more prospects for increasing their incomes through better employment and increased trade and commercial activities. Reduced transport fares and freight transfer costs are expected, as bus and truck operators compete within a larger and growing market. The project also developed the market areas for local people by widening the roads with the provision of footpaths, drainage, and safety barriers. About 10.35 million people, including 5.05 million women, have indirectly benefited from the project.

Regional role. Inadvertently, the project also contributes to regional integration among countries in South Asia. The improved project roads effectively linked two national highways ${ }^{6}$ and strengthened connectivity with the subregional road network linking Nepal and Bhutan, which increases the potential for economic development through greater subregional trade and commerce. By contributing to cross-border transport in South Asia, the project supports the SASEC Program, ${ }^{7}$ which aims to promote prosperity, improve economic opportunities, and build a better quality of life for the people in the subregion.

6 These are the National Highway 5 (Banglabandh-Panchagarh-Thakurgaon-Dinajpur-Rangpur-Bogra- Dhaka), and National Highway 509 (Rangpur-Lalmonirhat-Burimari). ADB. 2013. Project Completion Report: Bangladesh: Road Network Improvement and Maintenance Project. Manila.

7 See SASEC Programs: http://www.adb.org/countries/subregional-programs/sasec 


\section{LESSONS}

ADB's Road Network Improvement and Maintenance Project offers lessons can be derived that may be useful to similar road development projects in the future.

Adopt participatory processes to involve stakeholders. The road-selection process involving stakeholders is a distinctive feature of the project. The feasibility study and extensive public consultations that gathered stakeholders' opinion to determine the project roads helped ensure that the benefits of the project would be enjoyed by the most number of people. Such participatory processes should be adopted in similar road rehabilitation and maintenance projects.

Formulate long-term action plan for road maintenance. The establishment of the Roads Fund Board and the 10-year maintenance financing strategy between the government and ADB ensures road maintenance financing for Bangladesh in the coming years, which would reduce the backlog in road maintenance activities. Such financing should enable the Roads and Highways Department to formulate a long-term action plan that includes initiatives related to institutional capacity building, developing private sector partnerships, and improving road safety through stronger stakeholder and community participation.

\section{Keywords:}

Rural roads, rural transport, road maintenance, road safety, Road Network Improvement and Maintenance Project, land transport, Bangladesh

\section{For further reading:}

- Project web page: http://www.adb.org/projects/32223-013/main\#project-overview

- Technical assistance page: http://www.adb.org/projects/documents/road-networkimprovement-and-maintenance-project-tar

\section{For further information:}

- Muhammad Nazrul Islam, Senior Project Officer (Transport), South Asia Department | mnazrulislam@adb.org

- Tyrrell Duncan, Technical Advisor (Transport), Sustainable Development and Climate Change Department|tduncan@adb.org

- Ki-Joon Kim, Principal Transport Specialist, Sustainable Development and Climate Change Department |kjkim@adb.org

- Dongxiang Li, Lead Regional Cooperation and Integration Specialist, Economic Research and Regional Cooperation Department | dongxiangli@adb.org 


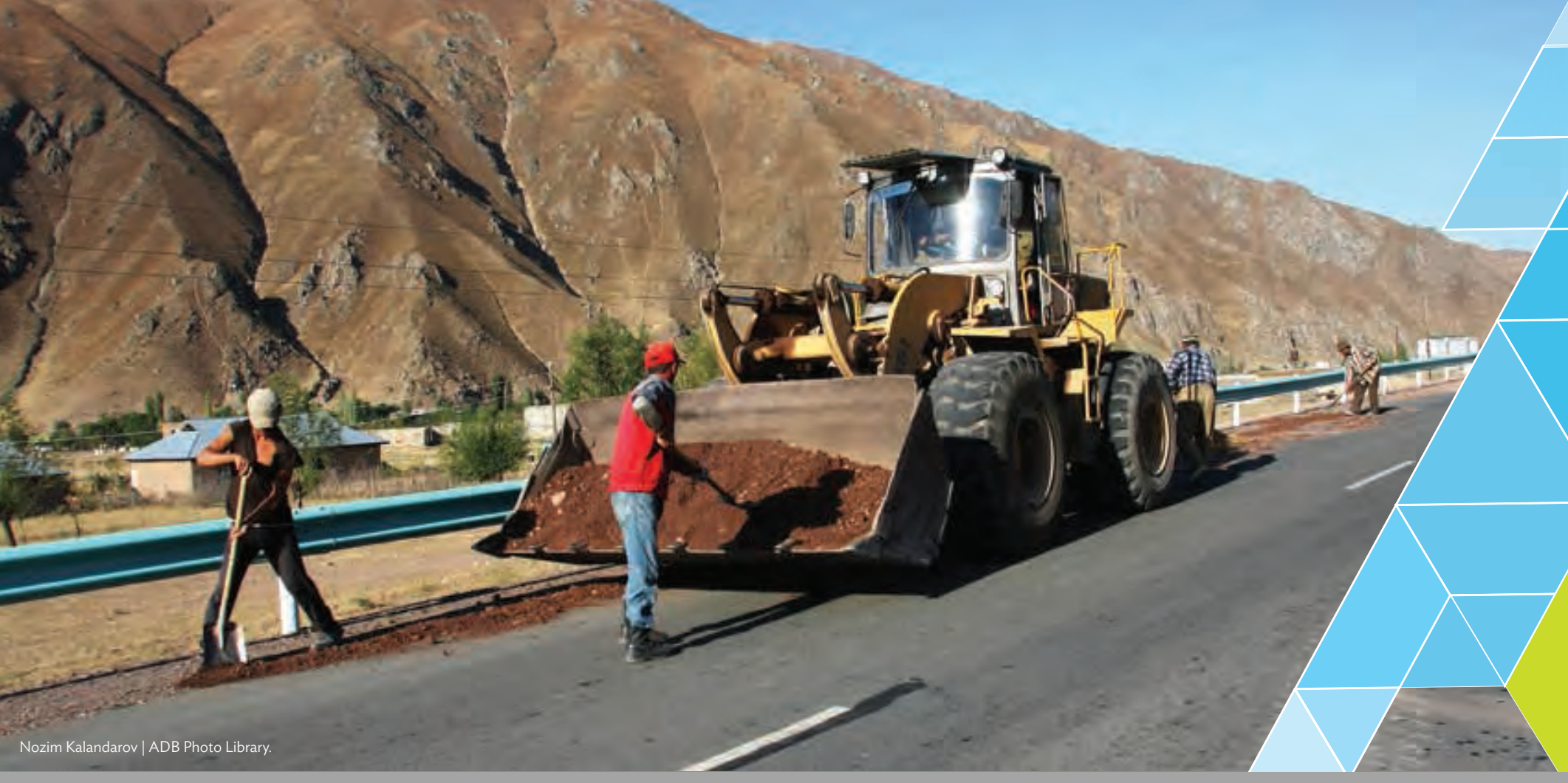

\section{MAKING ROADS LAST LONGER:}

Better Road CaRe IN the People's Republic of China

The deteriorating trunk road network in Yunnan Province, People's Republic of China needed better road maintenance and road asset management to improve the roads' sustainability.

ADB approved the Yunnan Sustainable Road Maintenance (Sector) Project in 2013 to raise the cost-effectiveness and efficiency of the province's road maintenance spending, improve its road maintenance systems, and develop a reliable road network database.

- The project will rehabilitate an initial 890 kilometers of trunk road pavements, develop a computerized and integrated information system for road asset management, and establish a monitoring and reporting mechanism for road maintenance.

- The project offers lessons for future projects involving road maintenance and road asset management, which are focused on improving financial management and institutional capacity. 


\section{CONTEXT}

T

runk roads in Yunnan Province, People's Republic of China

(PRC) are in poor condition. The non-tolled trunk road

network provides vital access to the 129 counties and overall

connectivity in the province. The deterioration has led to higher transport costs, low road safety standards, environmental degradation, and the slowing down of potential economic growth. Yunnan needed to take better care of its trunk roads to keep up with countrywide development.

Yunnan is a landlocked province in the southwestern region of the PRC. In 2011, about $27 \%$ of the province's rural residents were living under the country's poverty line of CNY2,300' annually. Much of this poverty is linked with a lack of connectivity, due to mountainous terrain that leaves little room for developing more railways, river transport, and other transport modes. Roads accounted for $58 \%$ of freight transport and $80 \%$ of passenger traffic. ${ }^{2}$

Yunnan's trunk roads make up a mere $11 \%$ of the province's 215,000 kilometers of roads, but many of them are important national and provincial highways that provide important links between rural roads and the province's expressways and urban center road networks. Managed by the Yunnan Highway Administration Bureau, about 44\% of the trunk road network is in poor or very poor condition. The risk

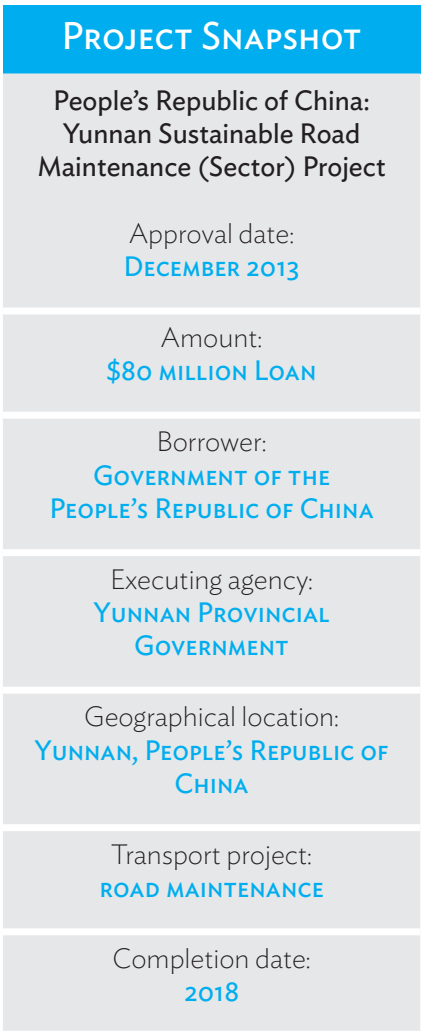
of being killed in a road crash in Yunnan's trunk roads was almost five times the rate in some developed countries. In 2011, there were 30 fatalities per billion vehiclekilometers $^{3}$ in the province. ${ }^{4}$

The poor condition of the trunk network is due in large part to original pavement designs that did not anticipate the large traffic volumes and heavy axle loads that have occurred. Frequent, extreme overloading has caused further deterioration. Road maintenance efforts to prevent degradation and reduce roughness have been inadequate.

Much of Yunnan's road maintenance problem is attributable to funding and institutional inefficiencies. In 2011, the total budget for road maintenance was $\$ 350$ million to cover the 24,089 -kilometer trunk road network and $45 \%$ of the province's paved road. Only $\$ 40$ million was spent on rehabilitation works and $\$ 47$ million on routine maintenance. Overall, only $25 \%$ of the road maintenance budget was actually spent on maintenance. Yunnan also does not have a good system for programming maintenance works in relation to economic returns, and has not sufficiently tapped the private sector for help.

CNY1.00 = \$0.1634 during project approval in 2013

2 ADB. 2013. Report and Recommendation of the President to the Board of Directors. Proposed Loan to the People's Republic of China for the Yunnan Sustainable Road Maintenance (Sector) Project. Manila.

3 Vehicle-kilometer is a measure of traffic flow, determined by multiplying the number of vehicles on a given road or traffic network by the average length of their trips measured in kilometers

4 ADB. 2013. Report and Recommendation of the President to the Board of Directors. Proposed Loan to the People's Republic of China for the Yunnan Sustainable Road Maintenance (Sector) Project. Manila. 


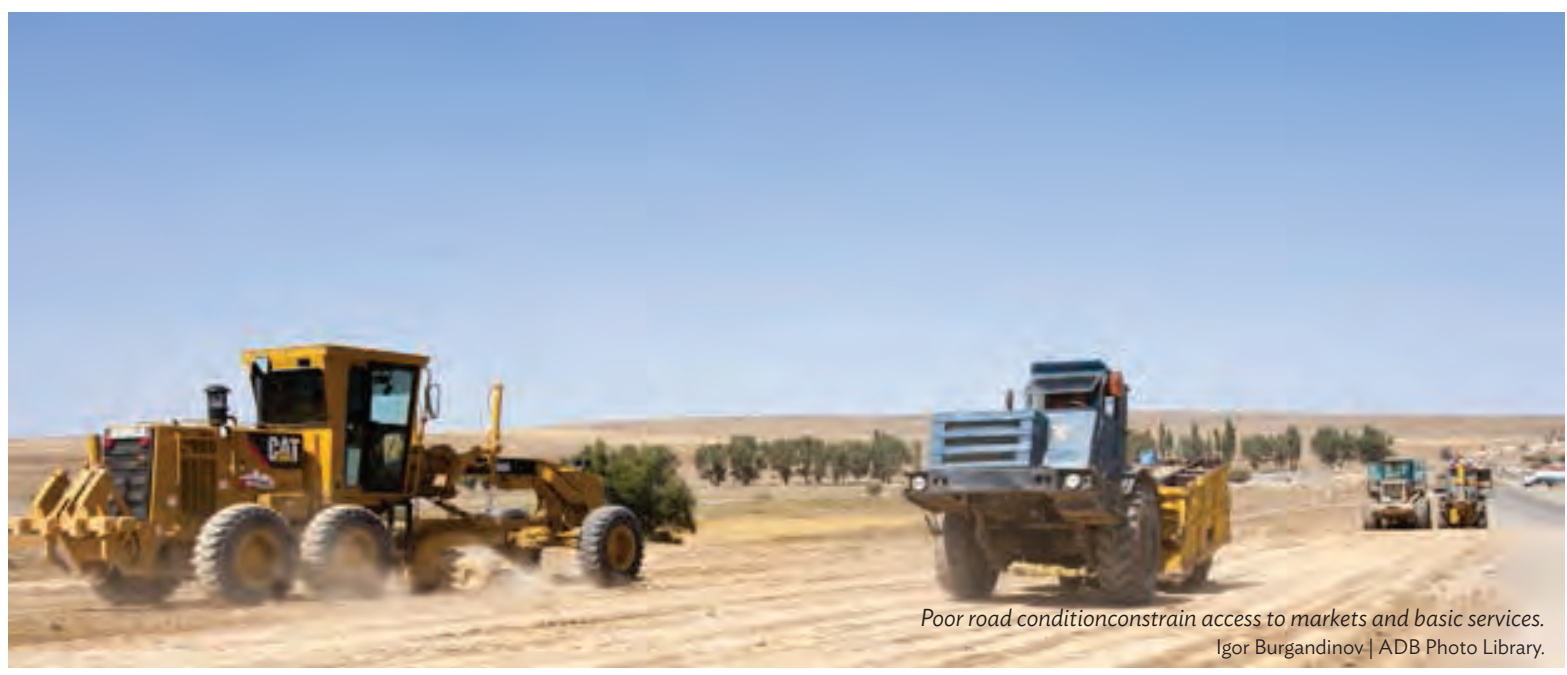

In 2013, ADB approved the Yunnan Sustainable Road Maintenance (Sector) Project to upgrade 890 kilometers of trunk roads in the province, many of which are connected with or form part of the GMS northern and north-south transport corridors of the GMS. The project will also test a performance-based road maintenance scheme, set up a road asset management system, and implement an institutional development plan.

The project is scheduled for completion in 2018.

\section{SOLUTIONS}

ADB's Yunnan Sustainable Road Maintenance (Sector) Project, financed through a sector loan, ${ }^{5}$ aimed to make the province's trunk road network more sustainable by raising the cost-effectiveness and efficiency of the province's road maintenance spending, improving its road maintenance systems, and developing a reliable road network database. It will promote institutional reforms for more efficient processes and technologies that will be introduced through training, new equipment, and new management principles and systems. Ultimately, these reforms will reduce the gap between maintenance needs and available resources. ${ }^{6}$ The following sections identify the innovative project management features.

Detailed road sector road map. The project's key institutional reform objectives are contained in the road sector road map. It details the major activities, performance indicators, and baseline data to enable accurate monitoring and evaluation. The roadmap defines the project performance targets, including improvements to trunk road network condition, trunk road maintenance cost-efficiency, road safety practices, and environmental sustainability.

To measure improvements to the trunk road network condition, the project set two crucial

5 Sector loans are usually provided to assist funding for materials, equipment, services, and consultancy required to implement development plans in a specific sector with multiple sub-projects. This type of loan also facilitates policies and systems improvement in the sector. The project qualifies for this modality because it comprises about 30 small-scale subprojects dispersed throughout

Yunnan, a sector development plan exists, the institutions involved have the capacity required, and it supports policy reforms that are mandated under the country's Twelfth Five-Year Plan.

6 ADB. 2013. Initial Environmental Examination. People's Republic of China: Yunnan Sustainable Road Maintenance (Sector) Project. Manila. 


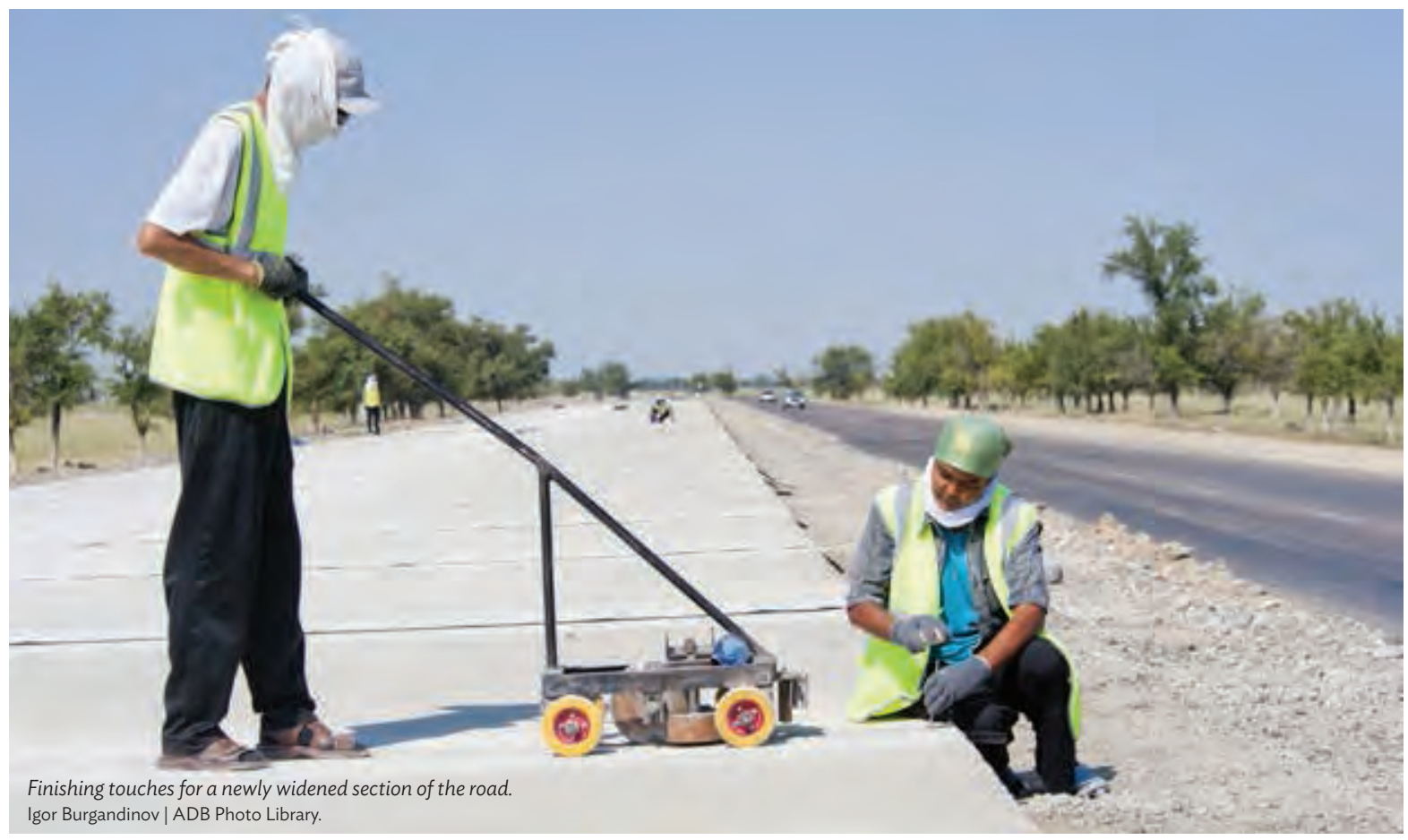

indicators: allocation of fuel tax to the Yunnan Highway Administration Bureau per kilometer of trunk road network, and percentage of the network receiving heavy or intermediate maintenance. These two indicators immediately show the relationship between resource inputs and work outputs.

The project specified five indicators to measure improvements to trunk road maintenance cost-efficiency. These include (i) percentage of trunk road network included in annual surveys, (ii) percentage of intermediate and heavy maintenance works according to asset management planning, (iii) percentage of maintenance budget allocated to implementation, (iv) number of kilometers per management staff and station staff member, and ( $\mathrm{V}$ ) percentage of maintenance work outsourced through bidding and performance-based contracts. This set of indicators underpins the key changes required to introduce efficient road maintenance management principles. It encompasses road database updates, asset management planning, budget allocation, staffing, and the outsourcing of road maintenance tasks.

Reliable road asset management system. An efficient and reliable road asset management system ensures sustainability of the road infrastructure, improves cost-efficiency, and reduces costs. The first step toward a reliable road asset management system is a reliable database. The existing databases of the bureau are incomplete and are not up-to-date as there is no real-time interface to enable constant updating. The project design assumes the development of a working interface between the Chinese Pavement Management System, which manages road data information and can generate standard reports in the Chinese language, and the Highway Design and Management IV software, which runs on an English language platform and is important in predicting pavement condition and determining the prioritization of works planning. Once established, the interface will enable optimized planning. This new integrated system will provide the bureau with a reliable basis for prioritizing road maintenance projects and provide adequate budgets for works. 


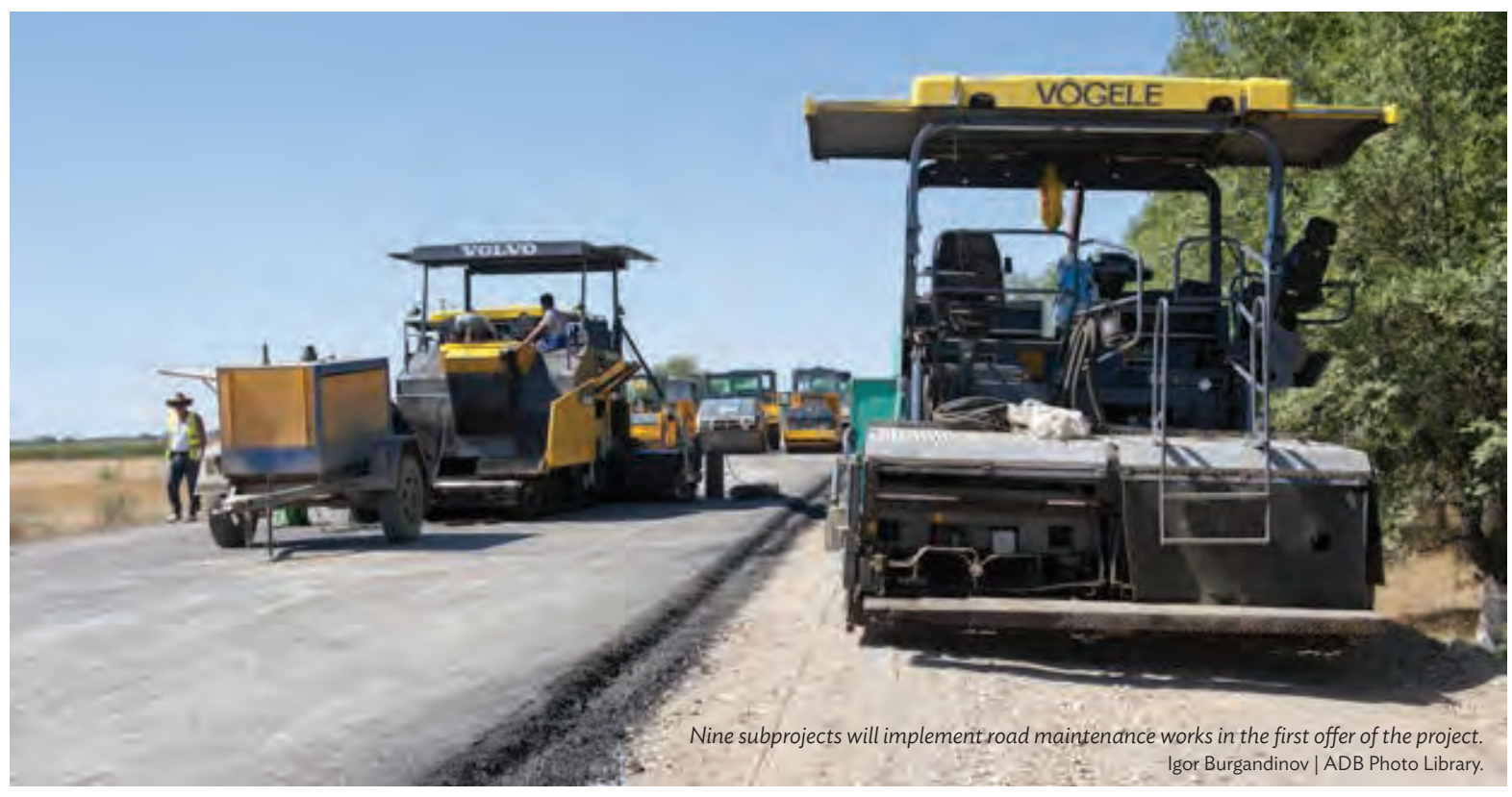

Phased implementation with subprojects. The project has four phases that will run for 5 years. Each phase will have subprojects covering a variety of maintenance works. One subproject will introduce performance-based road maintenance contracting, a first for Yunnan. Nine subprojects will be undertaken in the first year. The subprojects for subsequent years will be identified annually, based on road condition surveys; traffic counts; and technical, economic, and social considerations. Approval for subsequent phases is also conditional; the bureau must illustrate progress on the important sector road map objectives. This phased subproject approval and implementation will enable the bureau to get used to spending its budget using its new and reliable road asset management system.

Institutionalized safeguards management: The Environmental, Social, and Safety Unit is a mechanism that will consolidate the environmental management, social development, and road safety functions of the bureau, ensuring that environmental, social, and road safety concerns are included in the planning, design, and implementation of maintenance works. It will conduct environmental assessments and stakeholder consultations, as well as road safety audits. The unit will also develop and evaluate environmental management guidelines, road safety engineering guidelines, and safety engineering measures.

Project safeguards screening. The project preparatory technical assistance developed a screening tool to assess the environmental impacts and risks associated with the subprojects. It includes a standard form that summarizes the engineering, planning, financial, social, and environmental conditions of the subprojects; and details the maintenance works to be undertaken. The form acts as a checklist which, when accomplished, determines the subproject's environmental classification and the follow-up actions required. For instance, a subproject determined by the tool to be under a particular category may require a general Environmental Management Plan and works contract clauses. Under another category, the tool may show that a detailed plan must be prepared and a list of potential mitigation measures must be provided for the subproject to be approved and implemented. 


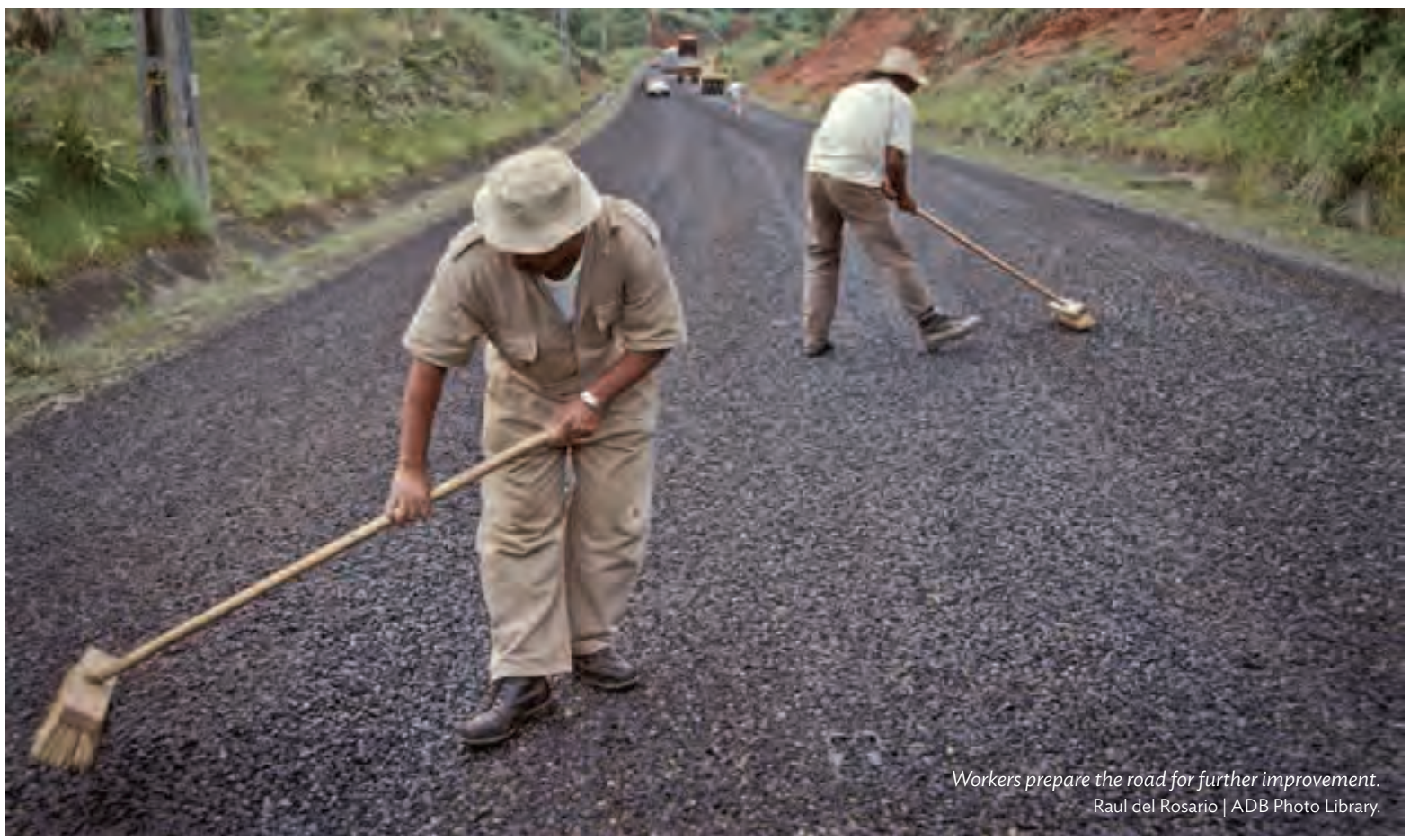

\section{RESULTS}

ADB's Yunnan Sustainable Road Maintenance (Sector) Project envisions a sustainable road asset management system in Yunnan, led by an improved Yunnan Highway Administration Bureau.

Preliminary road rehabilitation. Phase 1 subprojects will work on 192 kilometers of national highways, provincial or tourism roads, 36 kilometers of which will consist of overlays and 156 kilometers of pavement rehabilitation works. These roads were selected for phase 1 based on their high traffic volume and poor condition. Subsequent phase subprojects will assist in rehabilitating approximately 890 kilometers of trunk road pavements.

Computerized and integrated information system. The project will provide the bureau with modern tools to assist in road asset management. With an integrated platform, the bureau will have a fully computerized road asset management system that will be linked with a geographic information system. This road asset management system will include applications on road condition evaluation, pavement management, and identification of routine maintenance needs. This system will be capped with works planning application, making it easier for the bureau to prepare and plan for regular maintenance works.

Monitoring and reporting mechanism. The project's reporting system focuses project stakeholders on progress against the institutional reform objectives. The reporting system assists the bureau in managing and monitoring road maintenance performance through quarterly and annual reports that measure progress against targets and baseline data, in accordance with the sector roadmap objectives. 


\section{LESSONS}

ADB's Yunnan Sustainable Road Maintenance (Sector) Project offers lessons for similar future projects involving road maintenance and road asset management, particularly those focused on improving financial management and strengthening institutional capacity.

Prioritize road asset management. Road asset maintenance is often overlooked in favor of new road construction. In all countries, short-term political ambition and important social objectives tend to dominate government's budget planning processes. ADB's engagement in the road sector needs to be cognizant of these natural competing forces, and take action to promote the protection of client government's increasingly valuable road asset base. Objective data capture tools and management processes can be used to counter this trend. Without intervention, newly built roads will deteriorate and entrap populations in a perpetual cycle of poor connectivity. To promote the sustainability of Yunnan's road network, the project management and maintenance planning systems will acknowledge the maintenance demands associated with the planning of new roads, and establish data capture and management systems accordingly. Doing this will provide client governments with an objective picture of a network's condition, its ability to service populations, the consequence of continued neglect, and will importantly quantify the long-term budget allocations required to protect the growing road asset base.

Establish targets and reduce financing gaps. Reforms in road maintenance are usually a slow process due to reluctance in how civil works are carried out and financed at a systemic level. Various stakeholders are involved, and all must realize the short-and long-term benefits from road maintenance activities.? In this project, although the government intended to raise the priority given to road maintenance, it was not easy to do so given competing priorities within the sector. ADB had to secure a commitment letter from the Yunnan provincial government to increase road maintenance budgets. Through policy dialogues with ADB, the provincial government was eventually able to establish a series of medium-term targets for road maintenance, which included raising the proportion of roads in good condition, reducing the gap between maintenance financing needs and budgets, increasing the share of the network that is rehabilitated each year, modernizing management systems and operational processes of the Yunnan Highway Administration Bureau.

Establish realistic performance measures for institutional development. The tangible outputs of institutional reforms can be difficult to ascertain given competing social, political, and institutional factors, such as in the case of Yunnan. At the onset, it will be helpful for projects to lay out specific, measurable, assignable, realistic, and time-bound (or "SMART") objectives, not just for infrastructure projects, but more so for institutional development. This will ensure that a project's institutional reform targets are clear and focused, quantifiable, and achievable within a given time frame.

Collect and manage quality data. The institutional reforms laid out by the project will be compromised without a reliable road network database, as inaccurate and inconsistent data will seriously hamper road budget prioritization strategies. As data collection is a resource-intensive process, careful consideration of data requirements is required. Key issues in this area include the selection of information and database systems and spatial referencing of assets. ${ }^{8}$ There are tools

7 ADB. 2013. Annual Evaluation Review. Manila. http://www.adb.org/sites/default/files/linked-documents/lssues-Road-Maintenance.pdf

8 New Zealand Asset Management Support. 2011. Quick Guide to International Infrastructure Management Manual. Wellington. 
available that can help projects select, capture, and secure accurate, timely, and quality data on road networks condition and traffic volume, which can be used daily for operation, and on a regular basis for planning. This data will enable the important road asset management objectives and, when linked with more integrated platforms that aid in road design and planning, can enhance road maintenance plans by assisting in the prioritization of maintenance works, contributing to cost-effectiveness and cost-efficiency, and ensuring road sustainability. Quality data will also bolster institutional reforms at the agency level, as it will provide an accurate basis for planning and for monitoring progress.

\section{Keywords:}

road asset management, road maintenance, roads, asset management, transport, road transport, road safety, road data collection, data collection and management, institutional development, Yunnan Sustainable Road Maintenance (Sector) Project, land transport, People's Republic of China

\section{For further reading:}

- Project web page: https://www.adb.org/projects/45030-002/main

\section{For further information:}

- David Fay, Transport Specialist, East Asia Department |dfay@adb.org

- Tyrell Duncan, Technical Advisor (Transport), Sustainable Development and Climate Change Department|tduncan@adb.org

- Ki-Joon Kim, Principal Transport Specialist, Sustainable Development and Climate Change Department|kjkim@adb.org

- Dongxiang Li, Lead Regional Cooperation and Integration Specialist, Economic Research and Regional Cooperation Department | dongxiangli@adb.org 



\section{Lessons from ADB Transport Projects: \\ Moving Goods, Connecting People, and Disseminating Knowledge}

From in-country to cross-country connections, whether by land, air, or water, transport is a key ingredient that enables nations to achieve economic and social development goals. ADB has been working with developing member countries to improve roads, airports, waterways, and other transport infrastructures to provide people with better access to economic opportunities, public services, domestic and international markets. This publication shares 20 case stories bearing practical knowledge and lessons for transport projects across Asia and the Pacific region under different socioeconomic and political situations.

\section{About the Asian Development Bank}

ADB's vision is an Asia and Pacific region free of poverty. Its mission is to help its developing member countries reduce poverty and improve the quality of life of their people. Despite the region's many successes, it remains home to a large share of the world's poor. ADB is committed to reducing poverty through inclusive economic growth, environmentally sustainable growth, and regional integration.

Based in Manila, ADB is owned by 67 members, including 48 from the region. Its main instruments for helping its developing member countries are policy dialogue, loans, equity investments, guarantees, grants, and technical assistance. 